Olivier Moreillon

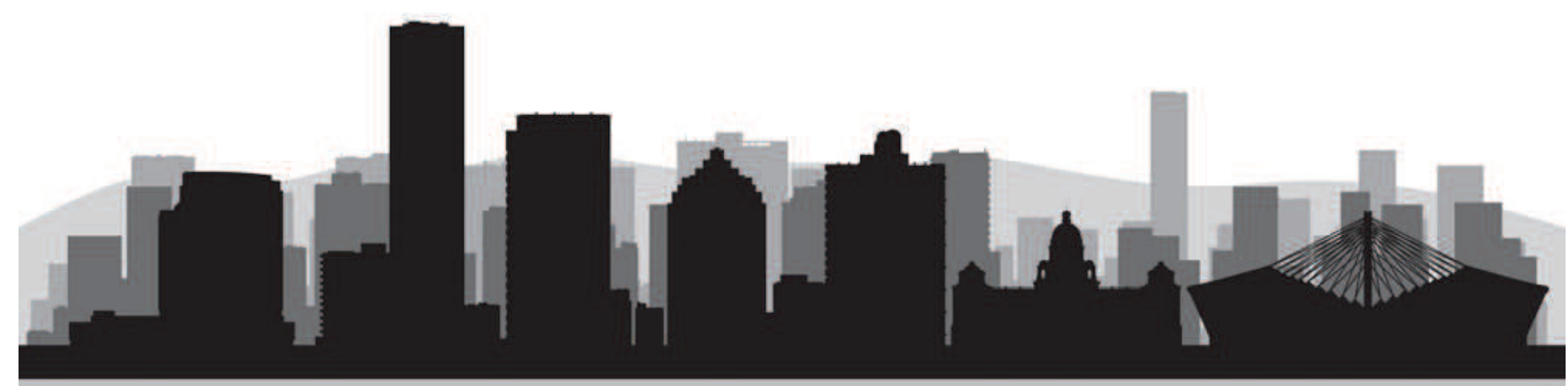

\title{
Reading the Post-Apartheid City
}

Durbanite and Capetonian Literary Topographies in Selected Texts Beyond 2000

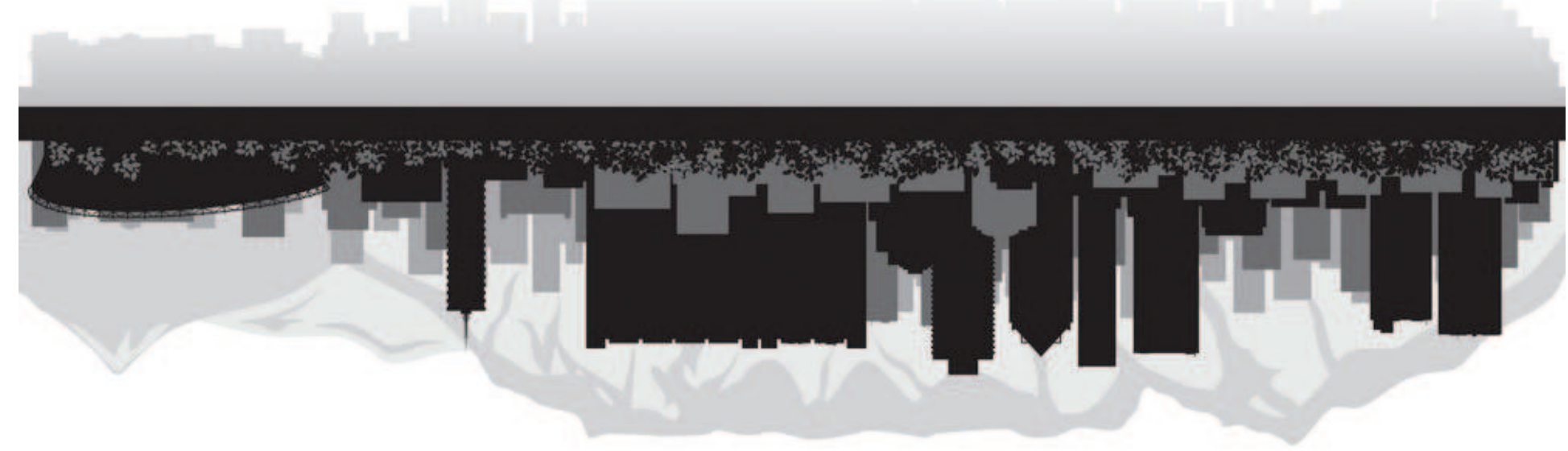

$\triangle \lambda \mathrm{o \gamma os}$ 

Olivier Moreillon

\section{Reading the Post-Apartheid City}

Durbanite and Capetonian Literary Topographies in Selected Texts Beyond 2000 


\section{(9)(1) $\Theta \Theta$}

Bibliographic information published by the Deutsche Nationalbibliothek

The Deutsche Nationalbibliothek lists this publication in the Deutsche Nationalbibliografie; detailed bibliographic data are available in the Internet at http://dnb.d-nb.de

(C) Logos Verlag Berlin GmbH 2019

Alle Rechte vorbehalten.

ISBN 978-3-8325-4830-8

Logos Verlag Berlin GmbH

Comeniushof, Gubener Str. 47, 10243 Berlin

Tel.: $\quad+49(0) 30 / 42851090$

Fax: $+49(0) 30 / 42851092$

http://www.logos-verlag.de 


\section{Dedication}

For my parents, Hugo and Daniela Moreillon, whose love and guidance have made me the person I am. And for Helton, for being my home and for your patience and support all along this at times seemingly never-ending adventure. 



\section{Acknowledgements}

But for the support, encouragement, and guidance of the many people I have had the pleasure to meet and collaborate with along the way, this book, which was submitted as my doctoral thesis in Anglophone Literary and Cultural Studies at the English Department of the University of Basel (Switzerland), would not exist.

Most importantly, I owe a heartfelt, gargantuan thank you to the magnificent Danyela Demir. Time and again you lent me a patient ear during one of our excessive (and more or less PhD-related) FaceTime conversations that left the Internet connection between Zürich and Augsburg, then Durban, and now Johannesburg temporarily overloaded. Your thorough reading of my work, your trenchant criticism, and your tireless encouragement have decisively influenced this project.

I am also grateful to my supervisor Prof. em. Dr. Therese Steffen (Universities of Basel and Zürich) whose seminar "Living the City" got me hooked on contemporary South African fiction back in 2008. Thank you for your patience and feedback. Thank you also for your tireless commitment within the Swiss South African Joint Research Programme (SSAJRP), an interdisciplinary exchange project between the University of Basel and several South African Universities from 2007 to 2015, which offered me a fruitful academic network within which I could conduct my research.

It is through the SSAJRP that I was introduced to Prof. em. Dr. Lindy Stiebel (University of KwaZulu-Natal, Durban) who over time has become so much more than my co-supervisor. Thank you, uMama Lindiwe, for opening your 'magic house' at the end of Pinsent Road, for your hospitality, your guidance, and your friendship. I will never forget the day I was sitting upstairs at your desk, writing part of my analysis on Mariam Akabor's Flat 9 while the Azaan was echoing from one of the nearby minarets, Bailey lying next to me, snorting an impatient demand for his evening walk.

I am furthermore indebted to my second co-supervisor Prof. Dr. Ina Habermann (University of Basel). It was in your colloquia that my spatiallyoriented theoretical approach matured and that my initial project idea ripened to a fully fleshed PhD project. Thank you, and Prof. Dr. Philipp Schweighauser, for your generous support and for hosting me as a research associate at the English Department of the University of Basel.

Finally, I would like to gratefully acknowledge the Swiss National Science Foundation (SNSF). I was a recipient of the Doc.CH scholarship between 
2014 and 2016, which allowed me to fully dedicate myself to my PhD during those two years. The SNSF, together with the SSAJRP, also funded my repeated research stays in South Africa between 2012 and 2016.

A shortened version of Chapter 1.1 "Mariam Akabor's Flat 9" appeared as "'Remember the Old Days?': Durban's Grey Street Area in Mariam Akabor's Flat 9" in Cities in Flux: Metropolitan Spaces in South African Literary and Visual Texts, edited by Olivier Moreillon et al., Lit Verlag, 2017, pp. 145-169. 


\section{TABLE OF CONTENTS}

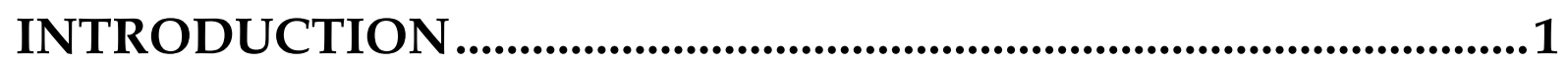

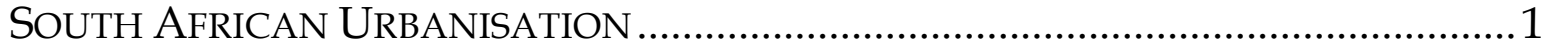

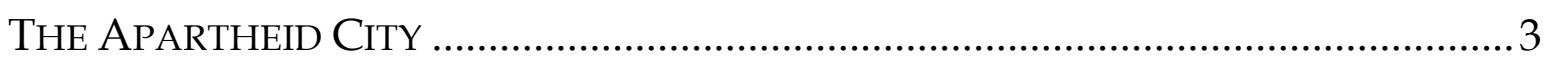

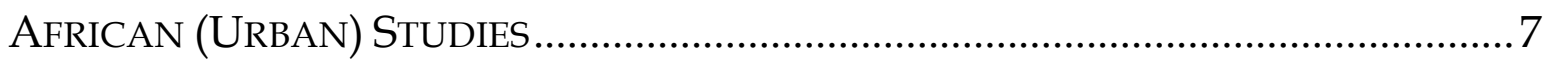

SOUTH AFRICAN URBAN THEORY, OR, ON TOPOGRAPHY ……….......................... 10

ENTANGLEMENT AND THE LITERARY CITY, OR, ON TOPOLOGY ...........................13

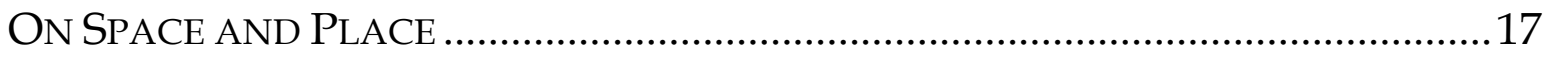

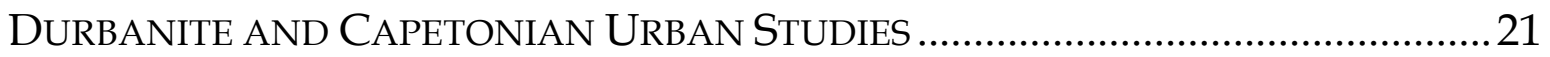

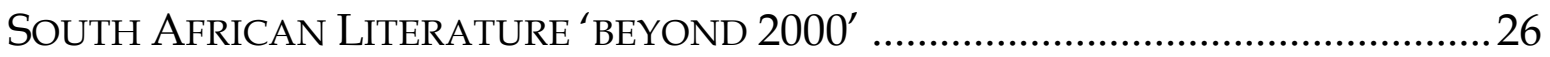

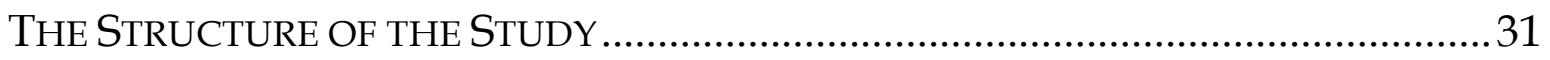

CHAPTER 1: (IM)MEMORABLE PLACES........................................35

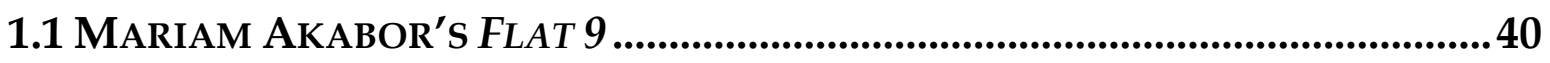

APARTHEID AND POST-APARTHEID NOSTALGIA IN FLAT 9 ................................. 43

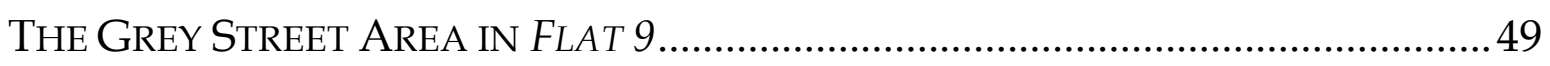

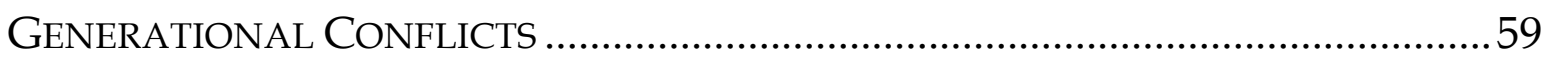

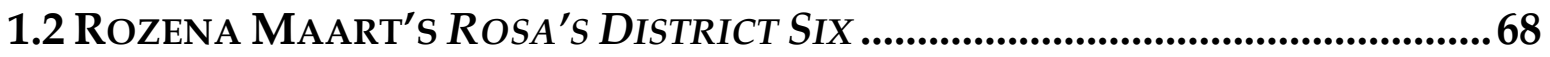

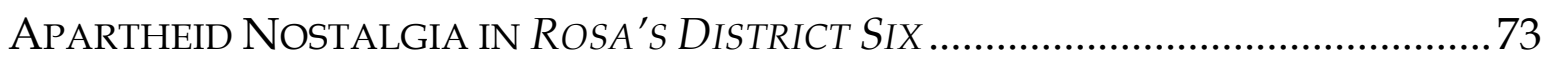

DISTRICT SIX AND CAPE TOWN IN ROSA'S DISTRICT SIX .....................................87

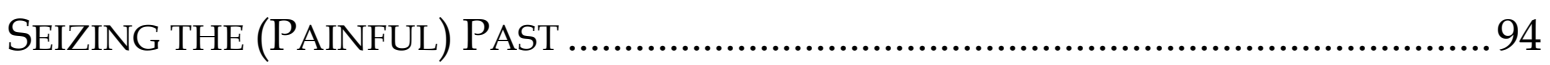

CHAPTER 2: MAD(DENING) PLACES ........................................103

2.1 JOHAN VAN WYK'S MAN BITCH .......................................................................109

Romantic Durban/Devilish Durban: The Point AREA IN MAN BITCH ....115

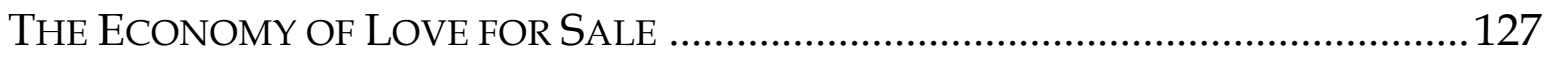

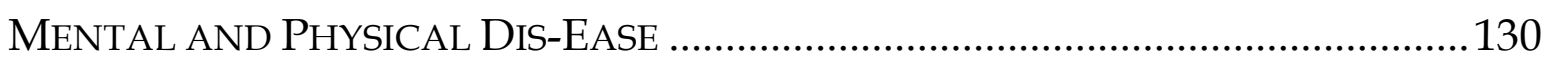

2.2 K. SELLO DUIKER'S THIRTEEN CENTS .......................................................141

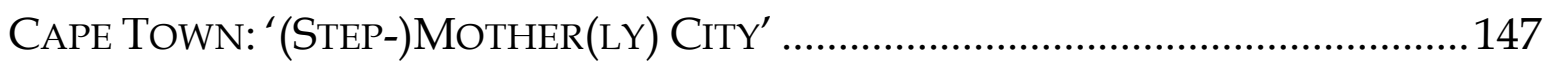

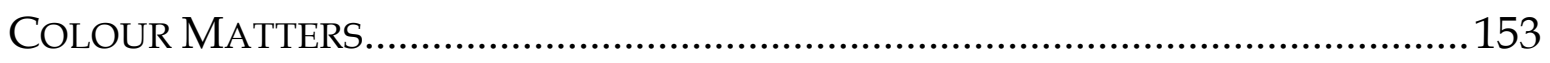

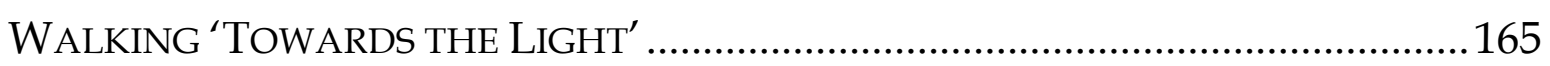


CHAPTER 3: USTOPIAN PLACES

3.1 BRIDGET MCNULTY's STRANGE NERVOUS LAUGHTER................................182

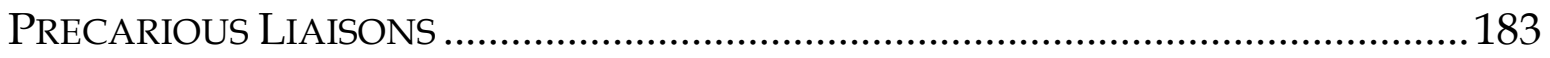

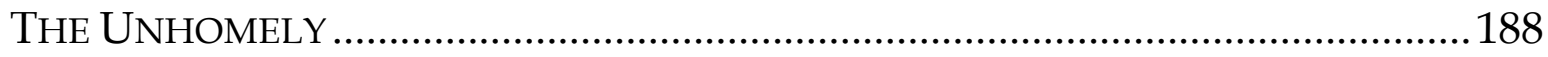

THE City of Durban IN StRAnge NeRVous Laughter ....................................192

MAPPING LOVE AND TRACING HOME-PLACES.................................................196

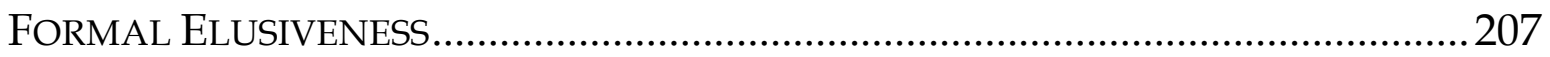

3.2 LAUREN BEUKES' MOXYLAND ..................................................................213

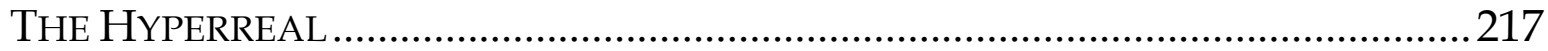

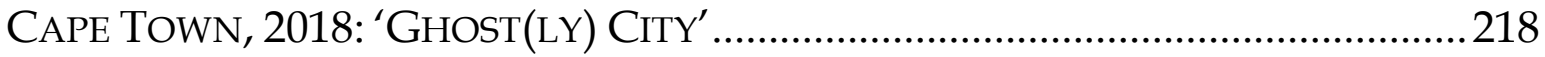

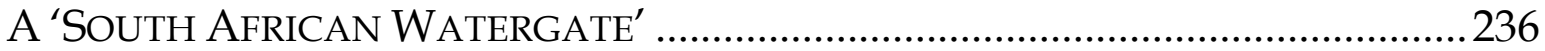

NARRATIVE AND SYMBOLIC HYPERREALITY _.....................................................239

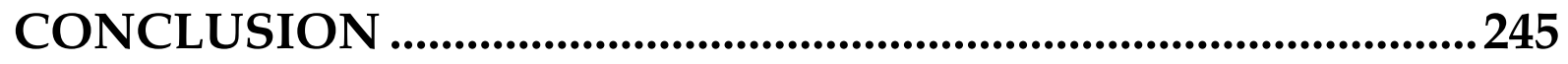

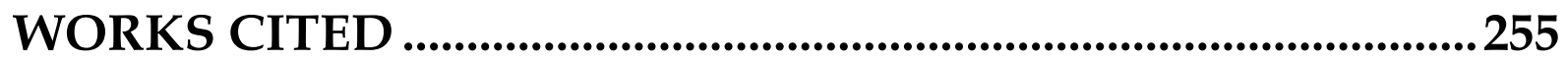

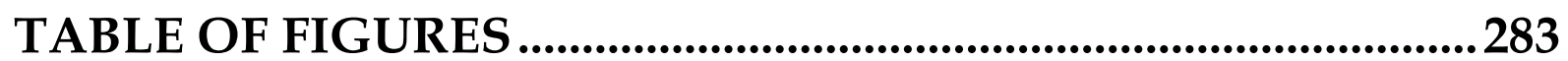




\section{INTRODUCTION}

The right to the city is far more than the individual liberty to access urban resources: it is a right to change ourselves by changing the city. It is, moreover, a common rather than an individual right since this transformation inevitably depends upon the exercise of a collective power to reshape the processes of urbanization. The freedom to make and remake our cities and ourselves is, I want to argue, one of the most precious yet most neglected of our human rights.

- David Harvey, "The Right to the City". (23)

With cities, it is as with dreams: everything imaginable can be dreamed, but even the most unexpected dream is a rebus that conceals a desire or, its reverse, a fear. Cities, like dreams, are made of desires and fears, even if the thread of their discourse is secret, their rules are absurd, their perspectives deceitful, and everything conceals something else.

- Italo Calvino, Invisible Cities. (44)

\section{SOUTH AFRICAN URBANISATION}

Historically, urban settlements in southern Africa can be traced back to precolonial times. Mapungubwe, situated in today's Limpopo province, was one of the first urban clusters in southern Africa and came into being around 1000 AD. ${ }^{1}$ Historian Vivian Bickford-Smith writes that "[a]s with the better-known Great-Zimbabwe to its north, Mapungubwe was probably linked to the Indian Ocean trade networks [...]. Yet neither of these settlements survived beyond the middle of the fifteenth century" (The Emergence 16). Then there were the Tswana 'agro-towns' which developed from 1500 AD onwards. Some of these agglomerations still existed when European colonisers advanced further inland in the late nineteenth century (Bickford-Smith, The Emergence 16; Freund, African City 3-7). Johannesburg, Cape Town, and Durban were the first more permanent urban agglomerations in southern Africa. These first urban popula-

\footnotetext{
1 Zakes Mda's novel The Sculptors of Mapungubwe recounts part of the kingdom's history. The novel, which begins in 1223 AD, follows the two friends Rendani and Chatambudza. Both sculptors, they could not be any more different from one another. While Rendani carves realistic sculptures and has three wives, Chatambudza's sculptures are purely imaginative and he is a bachelor, which is atypical for a man of his age. As the novel progresses, Rendani's discontent with Chatambudza grows and the two become rivals when they fall in love with the same woman. The novel is Mda's imaginative re-mapping of part of southern Africa's history.
} 
tions were not considerable in size, however. It was only by the early twentieth century that the population of the three cities exceeded 100,000 inhabitants for the first time or at least came close to it, but by 1911, Johannesburg had 237,104 inhabitants, while Cape Town and Durban had populations of 161,579 and 89,998 , respectively. The sudden surge in urbanisation in the second half of the nineteenth century was due to the 'mineral revolution'. In 1870, diamonds were discovered in Kimberley and the world's biggest gold deposit was found on the Witwatersrand in 1886 (Bickford-Smith, The Emergence 1617; Browett 14-17).

By that time Cape Town and Durban, the two cities I focus on in my study, already had long-standing histories. Cape Town, originally established as a way station for ships of the Dutch East India Company by Jan van Riebeeck in 1652, was taken over by the British in 1806 (Bickford-Smith, The Emergence 20-22; Browett 10-11; Worden et al. 15-16, 87-88). Bickford-Smith states that "British control over the Cape from 1806 increased the pace of urban growth" and the city of Cape Town henceforth profited from agricultural exports of goods such as ostrich feathers and wine (The Emergence 22). The city's economic successes lead to the construction of a harbour and railway in the 1860s. The latter connected the city to its farming hinterlands and, later, after the discovery of diamonds, also to Kimberley. Durban was established "as an offshoot British settlement at the Cape" in 1824 (25). In contrast to Cape Town, “[ $\mathrm{t}]$ he rate of Durban's economic and demographic growth before the mineral revolution was associated with sugar milling and export, with the building of sugar mills as well as small factories for other food and clothing production" (26). It was this increasing need for workers on these sugar plantations that led, between 1860 and 1911, to the importation of indentured Indian labourers, who were bound to five-year contracts before they were freed and could return to India (Browett 13; Freund, Insiders 3; Rosenberg, "Spatial Evolution" 18). Besides indentured labourers, there were also 'free' Indians who came to South Africa to open their own businesses (Bickford-Smith, The Emergence 26; Rosenberg, "Spatial Evolution" 18). Durban's Grey Street area, which is the focus of Chapter 1.1, became the new 'home' of what was to develop into the world's largest Indian diaspora. Durban's predominantly Zulu-speaking, black population, according to Bickford-Smith, would frequently "work stevedoring at the docks, as day labourers in the building industry, in laundry work or domestic service or [...] as rickshaw pullers. Further alternatives were [...] employment as domestic workers or self-employment in the informal sector, as small-scale traders or beer-brewers" (The Emergence 28-29). The em- 
ployment possibilities for Cape Town's black population were similar, apart from rickshaw pulling which is a distinctly Durbanite phenomenon.

\section{THE APARTHEID CiTY}

Mixed residential areas existed both in nineteenth-century Cape Town and Durban in the form of District Six, the focus of Chapter 1.2, and the Grey Street area, for instance. In the course of the nineteenth century, however, the white population increasingly relocated to more exclusive locations within South Africa's cities. With the emergence of the tramway in Cape Town in the second half of the nineteenth century, for example, the more affluent (white) population withdrew from the increasingly densely populated inner city and relocated to the city's southern suburbs or to Sea Point and Green Point (Bickford-Smith, The Emergence 24 and "The Origins" 37; Hart 119).

First attempts at urban segregation, however, can be traced to the midnineteenth century when different cities in the Eastern Cape and the Orange Free State endeavoured to separate the African and white populations (Robinson, The Power 51), but "an inadequate state machinery coupled with an unwilling black population meant that many well-laid schemes for control were thwarted or failed and had to be improved upon" (52). Durban's so-called 'Shepstone system', which was introduced in 1874, was one of the 'successful' early segregation schemes (Bickford-Smith, The Emergence 28-29; la Hausse 3940; Hemson, "In the Eye" 148-149). It imposed a night curfew on African labourers and "required payment of fees, registration and the wearing of badges by African employees" (Bickford-Smith, The Emergence 29). Another example is the passing of the Natal Beer Act in 1908, which established a municipal monopoly on the brewing of traditional beer. The proceeds of what became known as 'the Durban system' "provided a way of paying for African administration that included segregated housing" (138). ${ }^{2}$ The Durban system offered a fundamental example for further legislative measures on a national level that followed after South Africa's Union in 1910. At the same time, these early examples of legislative endeavours in an attempt to control the urban influx show how Africans were refused their basic "right to the [South African] city", to borrow David Harvey's argument. From the very outset of the country's urban history, Africans were denied active participation in "reshap[ing] the

\footnotetext{
${ }^{2}$ For a more detailed discussion of the Durban system see la Hausse; Hemson, "Class Consciousness"; Swanson.
} 
processes of [South African] urbanization" (23), despite the fact that they were indispensable to their economic functioning in the first place.

A number of further segregation laws followed during the period from 1910 to 1948. The list below shows some of the most important segregation laws from the pre-apartheid period (Browett 17-20; Clark and Worger 21-24; "Apartheid Legislation"):

- The 1911 Mines and Work Act prohibited Africans from carrying out more skilled work in the mines, which was the preserve of whites.

- The 1911 Native Labour Regulation Act determined the employment procedures of Africans who had to be recruited in the countryside, fingerprinted, and issued an identity document that allowed them to go and work in the city. A breach of employment contract or disregard of the length of their right to remain within the city resulted in detention and hard labour. The law is a precursor of the 1952 Pass Laws (see below).

- The 1913 Natives' Land Act (later renamed the Bantu Land Act and the Black Land Act) limited Africans' rights to own and rent land to specific areas that comprised a mere seven per cent of South Africa's territory.

- The 1923 Natives (Urban Areas) Act further specified the management of Africans within South Africa's cities and limited their accommodation to townships in the outskirts or municipal housing.

- The 1927 Native Administration Act (subsequently renamed the Bantu Administration Act and the Black Administration Act) separated the management and organisation of South Africa's African population from the management and organisation of its white population and passed all responsibilities relating to Africans to the Department of Native Affairs.

- The 1936 Representation of Natives Act effectively deprived Africans of their political rights. Henceforth, Africans were only allowed to vote for a small number of white representatives.

These are, as mentioned above, only a few examples of the many laws from the pre-apartheid period. While the laws are all concerned with the curtailing of the rights of South Africa's black population, it should be mentioned that the rights of South Africa's Indian population were also increasingly undermined. The 1943 Asiatic Trading and Occupation of Land (Transvaal and Natal) Restrictions Act (also known as the 'Pegging Act') and the 1946 Asiatic Land Tenure and Indian Representation Act (later renamed the Asiatic Land Tenure Act, also known as 'Ghetto Act'), which is comparable to the $1913 \mathrm{Na}$ - 
tives' Land Act and its consequences for the country's black population, restricted the Indian population's rights to buy and own land (Rosenberg, "Spatial Evolution" 28-29; "Anti-Indian Legislation").

By the time the National Party (NP) came to power in 1948, the segregation of South Africa's non-white population in general, and its African population in particular, was thus already in place. In fact, "[m]any apartheid laws merely elaborated on previous colonial policies and segregation legislation" from the pre-apartheid period (Clark and Worger 37). The following legislative measures are among the most notorious of the many apartheid laws (Browett 20-23; Clark and Worger 48-66; “Apartheid Legislation”):

- The 1949 Prohibition of Mixed Marriages Act forbade, as the name suggests, marriages between whites and non-whites.

- The 1950 Immorality Amendment Act forbade sexual contact between white and black people.

- The 1950 Group Areas Act, one of the key laws of apartheid, permanently institutionalised racial segregation. It allocated each racial group to particular living areas within the city, reserving the inner city for its white residents and banning its non-white population to the margins. Until the mid-eighties, thousands of blacks, Indians, and coloureds were relocated on the basis of this law.

- The 1950 Population Registration Act sought the classification of South Africa's citizens into three distinct races: whites, blacks (or 'Natives'), and coloureds. Indians, who were initially not recognised as permanent citizens of the country under this act, were added in 1959 and classified as 'Asian.' Initially, people were "classified primarily on the basis of their 'community acceptability,'" before a person's appearance and descent were given more emphasis in later amendments of the act in 1962, 1964, and 1967 in order to prevent coloureds and blacks with lighter skin complexions from 'passing' for white (Clark and Worger 49).

- The 1952 Native Laws Amendment Act and the Abolition of Passes and Co-ordination of Documents Act, commonly also known as the Pass Laws, introduced, and regularised, the issuing of pass books black South Africans had to carry with them at all times and had to present on request of a police officer. A black person furthermore had seventy-two hours to procure employment once they entered a city and had to leave again should the time elapse and they were unsuccessful in acquiring employment. 
- The 1953 Bantu Education Act separated the education of South Africa's white and black population. Black people's education intended to "mould Africans into compliant citizens and productive workers" and to prepare them "in accordance with their [limited] opportunities in life" (Clark and Worger 55).

- The 1953 Reservation of Separate Amenities Act, lastly, institutionalised separate infrastructures for white and black South Africans such as separate toilets, parks, beaches, entrances to buildings, and separate seats in public transport. The law also implied a qualitative difference in the amenities provided for the different races.

Many of these laws were subsequently adapted on several occasions in order to eradicate possible grey zones. It becomes apparent how extensive the interference of the many apartheid laws, together with those from the preapartheid period, was in the lives of South Africa's non-white population. Horst Nopens distinguishes three parallel levels on which apartheid legislation took effect: the macro-, meso-, and micro-level. While the homeland policy, for example, based on the 1913 Natives' Land Act operated on a macrolevel, the 1950 Group Areas Act was intervention on a meso-level. The prohibition of mixed marriages, in turn, constituted an intervention on the microlevel as it sought to regulate people's social interactions (20). The apartheid regime was thus a complex 'fabric' of a multitude of laws with national, more local (i.e. particularly urban), and interpersonal scopes all at once. Turok rightly states that the apartheid regime essentially sought "to fracture the physical form of [South Africa's] cities and disrupt the lives of black residents through forcing them to the periphery" (1). This spatial fracturing of South Africa's geography resulted in diverging understandings and meanings of space and place (both urban and rural) for the different racial (and social) groups of South Africa's population over time. While South Africa's white population was the primary locus of privilege of the apartheid regime, the country's black population felt the system's detrimental impact the most. South Africa's coloured and Indian populations, in turn, were left somewhere in-between, neither profiting from white privileges nor accepted by blacks as suffering the same, all-encompassing form of discrimination that South Africa's black population faced.

Urbanisation in South Africa has thus indeed happened under "rather unique circumstances", as Frédéric Giraut and Céline Vacchiani-Marcuzzo claim, since it was: 
linked first of all to the different phases of economic development which gave the main role to port cities on the periphery, and later to mining cities in the interior. The processes of urbanisation were then subjected to a shaping process in the form of spatial and ethnic apartheid policies, on national scale and on intra-urban scale. It is for this reason that the South African town and city system is often presented as being specific or unique, and difficult to compare with any other [...]. (46)

With the demise of apartheid, South Africa's non-white population was no longer legally restricted in their choices of residency within the city and their movements within the country at large (Turok 14), "leading to huge upswings in urban populations" as Garth Myers argues with regard to postcolonial Africa at large (53). What Myers sees as generally characteristic for the postcolonial city in Africa certainly holds true for the post-apartheid city. He rightly posits that "[j] ust as apartheid South Africa represented an extension of colonialism's geographies, the post-apartheid era in many ways parallels the postcolonial era for other cities across the continent" (57).

\section{African (URban) STUdies}

The African city of the postcolonial era has received considerable attention within urban studies. The work of several renowned scholars comes to mind here. There is Filip de Boeck's work on Kinshasa, Democratic Republic of Congo, in collaboration with the photographer Marie-Françoise Plissart (de Boeck and Plissart), or Bill Freund's work both on Durban as well as the (South) African city more generally (Insiders; African City; and (D)urban Vortex [together with Vishnu Padayachee]). Further examples are Richard Grant's work on Accra, Ghana, or Sarah Nuttall and Achille Mbembe's work on Johannesburg, South Africa (Nuttall and Mbembe; Nuttall, Entanglement), and there is no getting around AbdouMaliq Simone and his work on Dakar, Senegal, Douala, Cameroon, Jakarta, Indonesia, Winterveld, South Africa and other cities (e.g. New Urban Worlds [together with Edgar Pieterse]; For the City; and City Life). The interest in the (postcolonial) African city, according to Myers, goes back to the mid-twentieth century, lost its 'attractiveness' as an object of study in the interim between the late 1960s and the early 1990s, and saw a 're- 
emergence' in the 2000s (1-2). ${ }^{3}$ In his overview of more recent studies on the African city, Myers shows how "it is still generally the case that cities in Africa are ignored, banished to a different, other, lesser category of not-quite cities, or held up as examples of all that can go wrong with urbanism in much of both the mainstream and even critical urban literature" (3-4). Myers consequently asks for "conceptions of fluid African urbanism" (14; my emphasis), a call that reminds of Achille Mbembe's argument in his landmark study, On the Postcolony.

Mbembe contends that Africa and the African subject have been caught in a general discourse of negativity (On the Postcolony 1 ) in which they, as 'the absolute other', are pinned against the West whose self-conception is defined via the things it is not or does not want to be, those being Africa and African subjectivities (2). The 'postcolony', according to Mbembe, denotes "a given historical trajectory - that of societies recently emerging from the experience of colonization and the violence which the colonial relationship involves"; it is "chaotically pluralistic" but "has nonetheless an internal coherence" and is "characterised by a distinctive style of political improvisation, by a tendency to excess and lack of proportion, as well as by distinctive ways identities are multiplied, transformed, and put into circulation" (102). Accordingly, the postcolonial subject's flexibility and fluidity in working its way around existing laws and regulations where and when necessary are among the chief characteristics of the postcolonial subject and its existence in the postcolony (129).

Among the scholars whose work has focused on alternative, more positive approaches to conceiving of the African city, one certainly has to highlight AbdouMaliq Simone's work. In For the City Yet to Come, Simone argues that, in African cities:

what we may know conventionally as legality and illegality, war and peace, the corporeal and the spiritual, the formal and the informal, and movement and home are brought into a proximity that produces a highly ambiguous sense of place. The ambiguities do occasion intense struggles over which identities have legitimate access to and rights over specific places and resources. But they also amplify the historical capacity of many African societies to configure highly mobile social formations. These formations emphasize the construction of mul-

\footnotetext{
${ }^{3}$ Further works on African cities which have arisen in this period of 're-emergence' are, for example, Robinson's Ordinary Cities; Simone's "Reclaiming", "Uninhabitable?", and Always. For a concise discussion of de Boeck's and Simone's work see Mbembe and Nuttall (6-8) or Myers (10-13). For a critique of Mbembe and Nuttall as well as a discussion of Robinson's work see Myers (9-10, 13-14).
} 
tiple spaces of operation embodying a broad range of tactile abilities aimed at maximizing economic opportunities through transversal engagement across territories and disparate arrangements of power. (2)

Simone suggests notions such as the 'informal' or the 'invisible' as ways to account for the socio-economic and -cultural dealings "in the gaps between clearly designated and defined urban institutions, spaces, and actions" (22). While the informal considers the multiplicity of 'alternative' ways of creating employment in the absence of other possibilities (24), the invisible becomes a means to identify the intricate networks of solidarity at play in African cities and strategies of working around these very networks in an attempt by individuals to gain independence (65). Informality in African cities plays such an important role that Myers, building on Simone's argument, suggests the notion of the '(i)n(f)ormal' to profess its familiarity and normality within the African context (70-103).

In his later work, Simone adds the concept of 'black urbanism':4

Blackness as a device $[\ldots]$ attempts to navigate through the entanglement of possibility and precariousness in urban life. In other words, where exclusion, the provisional, the marginal, and the ephemeral - all thought to point to a certain collapse of urban civility and justice - are also the conditions under which new forms of the urban life are generated. ("Black Urbanism" 36)

More recently, Simone has used the notion of '(un)inhabitability' to account for African (and Asian) urbanity (Always and "Uninhabitable?"). Considering the extent to which urbanites in Africa (and Asia) transform seemingly uninhabitable spaces (and places) into habitable ones out of their necessity to survive, Simone suggests that we re-consider the notion of the uninhabitable as another form of habitability rather than stipulating the concept within the domain of stagnation and reactionism (Always 16-23). Overall, the various concepts show how Simone's work has constantly sought to re-imagine the African (and Asian) city in a more positive light.

Simone is, of course, not the only scholar with the agenda to reconceptualise the African city. Jennifer Robinson, whose case studies, among other African cities, focus on Port Elizabeth (The Power), Durban, and Johannesburg (Ordinary Cities), has similarly criticised the deadlock of the (South) African city's theorisation 'between modernity and development' in which the

\footnotetext{
${ }^{4}$ Black urbanism is a concept Simone first introduces in his second book, City Life from Jakarta to Dakar.
} 
(South) African city has been portrayed as 'lagging behind'. Robinson argues that "[i]n a deeply colonial move, it is the West that has been seen as the site of modernity and other places that have been entrained as not-modern or less modern through the transformation of historical time into geographical difference" (Ordinary Cities 13-14). Modernity thus became a privileged locus of a few select cities of the northern hemisphere to whose standards the rest of the world, and the global south in particular, had to live up to. In order to overcome this theoretical deadlock, Robinson pleads for a return to a comparative urbanism that, at the same time, accounts for the postcolonial character of African cities and the opportunities as well as problems that this postcolonial character implies (168).

\section{SOUTH AFRICAN URBAN THEORY, OR, ON TOPOGRAPHY}

Within the South African context, the city of Johannesburg has seen the most comprehensive theoretical re-conceptualisation. ${ }^{5}$ Of the many studies, Sarah Nuttall's and Achille Mbembe's Johannesburg: The Elusive Metropolis has proven particularly fruitful as a starting point for my own study. In line with, and building on, Mbembe's postcolonial theory, Nuttall and Mbembe endeavour to re-negotiate the negative stigmatisation of the South African urban. 'Elusiveness', as suggested in the book's subtitle, is a central theme in Nuttall's and Mbembe's rethinking and rewriting of Johannesburg. Johannesburg, they argue, is a city of double elusions. On the one hand, Johannesburg is 'elusive' because of the gulf between the city's social and cultural reality and its representation in theory and discourse (25). According to Nuttall and Mbembe, academia has not only failed to provide a satisfactory theorisation along racial and economic lines to explain the consequences of the severe infringements on the historical development of South Africa's cities, but it has also failed to account for Johannesburg's "city-ness" in the context of a worldwide discourse on metropolitanism (15). On the other hand, Johannesburg's 'elusiveness' can also be ascribed to "the multiplicity of registers in which it is African (or perhaps not at all, or not enough); European (or perhaps not, or no longer), or even American (by virtue of its embeddedness in commodity exchange and its culture of consumption)" (25). Johannesburg, they argue, is marked by its "ceaseless metamorphoses", which is owed to its condensed historical, social,

\footnotetext{
${ }^{5}$ See e.g. Judin and Vladislavić; G. Gaylard, Marginal Spaces; M. Murray, City of Extremes and Taming; Nuttall and Mbembe; Nuttall, Entanglement; and Kruger.
} 
and economic development in comparison to Western cities (18). Colonialism and globalisation have thereby significantly shaped the city's "fractured, colliding, and splintered urban life" (5).

Striving for new analytical and interpretive approaches, Nuttall and Mbembe thus emphasise the importance of extending the perception of the urban beyond its economic, infrastructural, and legal materiality to its creative and imaginative repertoires. Such a shift calls for "a more complex anthropology of things" (8). Simplistic binary oppositions need to be reconsidered in favour of a richer investigative vocabulary. Taking "formality" and "informality" as an example, they argue that "the 'informal' itself expresses a 'form'. It simultaneously hides and reveals other rationalities. In African cities, forms can be thought of as conjoined with signs, and as a series of operations (ways of doing, of making)" and the essential aim is "to capture these rhythms and operations via a rehabilitation of the concept of the "metropolis'" (9; original emphasis). Their suggested dialectic captures Johannesburg in its spatiality. Considering the city's planning and governance, Nuttall and Mbembe decode Johannesburg's double tension along horizontal and vertical axes. The traces of colonialism and globalisation, they argue, manifest themselves not only in Johannesburg's eclectic architectural mix but are also "built into its morphology and geological structure between the life below the surface, what is above, and the edges" (18).

Historically, an east-west and north-south division marked the city horizontally. While the former separated Johannesburg's English- and Afrikaansspeaking lower middle class, the latter divided the city's southern suburbs from the upper class residential areas in the north. Apartheid's "principle of proximity and social distance" (21) additionally reinforced this horizontal rift. Johannesburg's vertical axis can be roughly plotted along the mines, which themselves demarcate the split into surface and below - identified by Nuttall and Mbembe as the metropolis and necropolis. Here, instead of restricting the analogy to the physical "underground", i.e. the remnants of the city's mining history, Nuttall and Mbembe elegantly avoid easy symbolism by including the "lower classes, the trash heap of the world above, and subterranean utopias" into their understanding of Johannesburg's "underworld" (22).

Nuttall's and Mbembe's approach thus has a decidedly topographical component, i.e. it emphasises representational aspects rather than spaceconstituting elements (Günzel, "Einführung" 5) by seeking "a general (metaphorised) ordering pattern" (Bachmann-Medick 299; my translation) along the lines of horizontal and vertical axes. The following concern, however, re- 
mains: Vittoria Borsò correctly reminds of the fact that space is not predetermined but rather produced. ${ }^{6}$ Consequently, topographical aspects are more or less explicitly based on topographical thinking, i.e. "a critical reflection about the conditions of spatial production, its dynamics or its emergence" (279; my translation). Put differently; topographical and topological aspects of space must always be studied in connection. In fact, the difference between the two is small. While topography aims at a description of spatial representations and gives importance to spatial expansion, topology focuses on structural elements of space and on positional relations (see e.g. Günzel "Spatial Turn", "Raum", and "Einführung"). It can be argued that the two approaches simply work under inverse auspices. In order to account for change and flexibility within postapartheid (power-)relations, it will be imperative to include the temporal, which seems to be sidelined in Nuttall's and Mbembe's topographical approach. This problem as well as Massey's suggested solution will be discussed below, under Space and Place.

The idea of a surface, a below, and the edges is nevertheless a powerful analytical tool as it consciously opposes dichotomous categories in favour of a more complex, three-dimensional analysis along a spatial dialectics that reads the vertical and the horizontal in connection to each other. Aspects of formality and informality, belonging and exclusion, or sameness and difference are in no way thrown overboard, but can be accounted for with more subtle nuances and more contextual flexibility. Nuttall's and Mbembe's emphasis of aesthetic rather than economic, political, or historical urban aspects enable a distinct focus on the South African city's multiplicity of imaginative and unique forms. The city becomes an entity that is composed of a myriad of spaces, and these spaces are built, occupied, and charged with meaning by people. Johannesburg's mining history distinguishes the city within the broader South African historical context. The application of Nuttall's and Mbembe's figurative distinction between the surface and the below, however, can also be applied when attempting to decode other cities, such as Durban and Cape Town.

\footnotetext{
6 The assumption that space is essentially the result of social production is central to Henri Lefebvre's The Production of Space. In Lefebvre's opinion, space is an integral part of the capital goods as well as social practice rather than a neutral 'container' for historical events to happen in. This main idea has become a central reference for neo-Marxist social geography whose most prominent representatives are David Harvey and Edward Soja.
} 


\section{ENTANGLEMENT AND THE LITERARY CITY, OR, ON TOPOLOGY}

In her book Entanglement: Literary and Cultural Reflections on Post-Apartheid, Nuttall continues the discussion of the South African city as a cultural intersection and access point to the interwoven and hidden cultural meanings therein. She describes South Africa as being in a state of 'entanglement', which she defines as follows:

Entanglement is a condition of being twisted or entwined, involved with; it speaks of an intimacy gained, even if it was resisted, or ignored or uninvited. It is a term which may gesture towards a relationship or a set of social relationships that is complicated, ensnaring, in a tangle, but which also implies a human foldedness. It works with difference and sameness but also with their limits, their predicaments, their moments of complication. (Entanglement 1)

The concept of entanglement is underpinned by several principles. Firstly, it emphasises the complexity of social realities. Its suggestion of multiple overlaps or intersections reveals its multi-layered, palimpsest-like nature. Furthermore, the concept has a distinct relational aspect, including both interpersonal relations as well as relations on a non-social, material level. Finally, entanglement also aims at a conceptual expansion. Even though it works on the basis of a binary opposition, its multi-perspectival nature is critical of simple dichotomies.

Nuttall's concept reminds of Joanne P. Sharp's and her colleagues' definition of the term in Entanglements of Power: Geographies of Domination/Resistance, published in 2000. Sharp et al. consider entanglement as a concept that "conjure[s] up the threadings, knottings and weaving of power, thus deploying a metaphor full of spatial imagery to convey the complexity of $[. .$.$] the workings$ of power, domination and resistance" ("Entanglements" 24). They further emphasise the term's usability beyond its metaphorical meaning as the concept "is intended to signal that relations of power are really, crucially and unavoidably spun out across and through the material spaces of the world" and conclude that "[i]t is within such spaces that assemblages of people, activities, technologies, institutions, ideas and dreams all come together, circulate, convene and reconvene $[\ldots]$ and it is only as a consequence of the spatial entangling together of all these of these elements that relations of power are established" (24). It is the concept's "focus on the domination/resistance couplet" (1) that I find particularly interesting as it not only includes notions of voice/voicing and activity as opposed to silence and passivity, but considers 
the latter as a distinct form of resistance (2). Considering the concept's overall similarity to Nuttall's discussion and use of the notion of entanglement in general, and her subcategory of creolisation to account for power-relations within the South African context in particular (discussed in more detail below), it is surprising that she does not make recourse to it.

Nuttall brings together six forms of entanglement as used - directly or indirectly - by various other scholars (2-11). These are: (1) historical entanglement, (2) the time of entanglement, (3) ideas of the seam, and of complicity, (4) entanglement of people and things, (5) implications of the DNA signature, and (6) racial entanglement. In what follows, I will pick out two of these forms of entanglement, which are particularly relevant for my own endeavours.

The first is the 'time of entanglement' as used by Mbembe in On the Postcolony. He argues that "the postcolony encloses multiple durées made up of discontinuities, reversals, inertias, and swings that overlay one another, interpenetrate one another, and envelope one another: an entanglement" (14). Entanglement, is thus a temporal principle, which, according to Mbembe, is subject to the following essential presuppositions: Time has to be seen as nonlinear and palimpsest-like. It is "an interlocking of presents, pasts, and futures that retain their depths of other presents, pasts and futures, each bearing, altering, and maintaining the previous ones". Time is furthermore "made up of disturbances, of a bundle of unforeseen events, of more or less regular fluctuations and oscillations". And finally, time comes in "ebbs and flows" and "cannot be forced into any simplistic model". Mbembe's concept of entanglement thus consciously discards a linear conception of time with the aim to emphasise the plurality of African experiences. The negligence of this plurality, he opines, would lead to an impoverished representation of African reality (16-17).

The second form of entanglement I would like to highlight is historical entanglement. Historical entanglement articulates the interdependence of blacks and whites since the colonisation of (South) Africa. Based on the work of Cornelis Willem de Kiewet, among others, Nuttall argues that "as this dependency [of blacks and whites in South Africa] grew, so the whites tried to preserve their difference through ideology - racism" and adds that "the emergence and articulation of racial difference was, in this context, a symptom of loss (loss of independence through increasing dependence on black labour)" (2).

In the South African context, such a historical entanglement is, however, not restricted to the interdependence of blacks and whites. The city of Durban 
is characterised by its historical entanglement of black (Zulu) and Indian culture. Apartheid's racial categorisation created an economic imbalance between blacks and Indians, which was particularly evident in Durban's property situation. The Natives' Land Act of 1913 resulted in a characteristic hierarchy where "Africans were tenants of Indian landowners, customers of Indian shopkeepers, and neighbours" (Freund, Insiders 38). The conflict between the two ethnic groups escalated on January 131949 because of an altercation between an Indian shopkeeper and a black customer in Victoria Street in Durban's CBD. Parts of Cato Manor, a residential area located about seven kilometres west of Durban's CBD, were occupied by blacks as a result of this contention. In the police's subsequent intervention 87 blacks and 50 Indians were killed and Cato Manor suffered substantial property damage (Mainet-Valleix 87-88).

The contradictory and paradoxical racial definitions, which are still 'common sense' in South Africa even after the demise of apartheid (see e.g. Posel, "Consume", "Common Sense", and "What's"; Erasmus, "Apartheid Race"), are a remnant of South Africa's historical entanglement of whites and non-whites. Nuttall argues that "while under apartheid racial discrimination was crucial to the twin issues of work and wealth, in the post-apartheid the politics of black empowerment plays an important role in shifting institutional power politics" (Entanglement 28-29). Race has moved from being the "locus of privilege" during apartheid to being the "site of redress" in post-apartheid South Africa, which, despite a greater level of racial mixing and a looser correlation between race and class, ironically still takes apartheid's racial classification as its basis (Posel, "What's" 68-69; see also Erasmus, "Apartheid Race" and Nuttall, Entanglement 28-30).

The concept of entanglement hence not only offers a striking snapshot of present-day South Africa but also an innovative alternative approach to decoding cultural meaning. It is first and foremost the flexibility and broad range of applicability that makes the concept so immensely useful to analyse the conditions, dynamics, and emergence of spatiality, i.e. its topology. Entanglement becomes a particular way of reading South Africa, "a means by which to draw into our analyses those sites in which what was once thought of as separate - identities, spaces, histories - come together or find points of intersection in unexpected ways" (Nuttall, Entanglement 11). This can either be done by using apartheid's segregational dialectics as a methodological tool in the description of South Africa's present situation, or by using new vocabulary and tools in our analysis of post-apartheid South Africa. Combining both approaches, 
Nuttall establishes three 'reading methods': (1) creolisation, (2) regional variations, and (3) race and class. While creolisation implies the violence, inequality, conflicts, and cultural ramifications (positive and negative) of entanglements, regional variation emphasises differences in their realisation and development due to geographical, topographical, social, and historical circumstances. Race and class have to be seen as a particular lens through which Nuttall analyses present-day entanglements within the South African context. Ultimately, Nuttall calls for an awareness of "new temporalities or velocities of the social" and promotes that such an enterprise has to "pay attention to those archives still at times undervalued and, in any case, under-written by historians and anthropologists in South Africa" (30).

One such archive Nuttall pays particular attention to is the literary city (Entanglement 33-57; see also "Literary City"). She purposefully draws on the rich pool of recent Johannesburg city literature (published between 1998 and 2004) in which "the city emerges in an even more self-conscious way an aesthetic, a political and an imaginary site, a vivid and explicit template for an entire array of social fears and possibilities" (Entanglement 36). With reference to her theoretical endeavours, both her own as well as those arising from her collaboration with Mbembe, post-apartheid fictional texts become the gateway to the contemporary perception of the street, the café, the suburb, and the campus as various city-spaces, which in turn are coupled with diverse figures such as the migrant worker, the ageing white man, the illegal immigrant, and the hustler (40-57). Equating this array of city dwellers to their respective spheres of activity are an addition to the established literary figure of the flâneur as inspired by the writings of Walter Benjamin's The Arcades Project and Michel de Certeau's The Practice of Everyday Life. Such entanglements of people and things, or instead, perhaps, entanglements of people and places, are innovative and much needed in the South African context as they offer a new perspective when decoding the South African metropolis.

However, Nuttall's analyses of the literary city nevertheless appear incomplete in some respects: The importance of power-relations is only marginally taken into consideration, even though her sub-category of creolisation is meant to account for this. Social hierarchies and their constitution as well as their effect on the characters' patterns of movement and spheres of influence, for example, are not addressed. Furthermore, narratological features, which necessarily filter, support, or manipulate aspects of space, time, and subjectivity in literary texts, are similarly sidelined and gender aspects are almost entirely neglected. In order to fill out the points I have sketched here, and to con- 
solidate my reflections up to this point, I will now turn to the concept of 'space' and 'place' as suggested by Doreen Massey.

\section{ON SPACE AND Place}

The British geographer Doreen Massey defines 'space' "as constructed out of interrelations, as the simultaneous coexistence of social interrelations and interactions" (Space, Place and Gender 264). Massey's conception relies essentially on the relational, and so here I will consolidate them with Nuttall's and Mbembe's topographical 'mapping' of the (South) African metropolis in relation to its spatially marked history, as well as Nuttall's topological reading of the literary city with reference to the conditions of the South African city's various entanglements - both also relational concepts at their core - under one theoretical framework. My following comments draw on Doreen Massey's spatial concept, not only because she conceives of space and time as inextricably linked, both to each other and to questions of subjectivity, but also because of the political framework within which she conceives it.

Massey's concept of space (and place) builds on three fundamental propositions: Firstly, space is the result of relations. It is "constituted through interactions, from the immensity of the global to the intimately tiny". Secondly, space is characterised by its multiplicity. It has to be considered "as the sphere in which distinct trajectories coexist; as the sphere therefore of coexisting heterogeneity". And finally, space is always under construction. It is "always in the process of being made. It is never finished; never closed;" it is "a simultaneity of stories-so-far" (For Space 9).

These propositions are the result of Massey's critique of a set of "unpromising associations" (7) made by various structuralist and post-structuralist theorists such as Claude Lévi-Strauss, Louis Althusser, Chantal Mouffe, or Ernesto Laclau to name but a few. On the one hand, her criticism is directed at their definitions of space and place along a set of dualisms which generally equates space to the general/universal, the abstract/conceptual, and the masculine, while place is linked to the local, the specific/concrete, and the feminine (Space, Place and Gender 9; For Space 17-19). Ultimately, such dualisms define space and place to the exclusion of each other (For Space 17-18), which not only defies the "radical contemporaneity" of space and place, i.e. the coexistence of many different spaces and places (99), but also places the spatial in a state of stasis (30). As a result, space is "de-politicized" and becomes opposed to time (Space, Place and Gender 250-51). On the other hand, Massey laments how 
modernist thinking has generally conceptualised space as triumphant over time, challenging the tendency of western philosophy to subordinate space to time (For Space 29-30). The history of modernity, for example, has generally been conveyed as the sequencing of diversified historical events along a unifying temporal trajectory in terms of progress (Power-Geometries 10-14; For Space 62-75). Another example is the extreme but nevertheless popular imagination (particularly in sociology and cultural studies) of globalisation as a form of unrestricted mobility within a borderless space under the sign of economic progress. Such a belief considers globalisation as an inevitable process and thus, again by temporalising it, renders it devoid of spatial difference (PowerGeometries 14-21; For Space 81-89). Both spatial interpretations, Massey argues, are wanting, as "[ $[\mathrm{t}]$ here was no simple isomorphism of place and culture under modernity, in spite of efforts [...] to produce it. Similarly, today, in the midst of the so-called space of flows of globalisation, new barriers are being erected, new fortresses are being built" (Power-Geometries 21).

In the South African context, any "simple isomorphism of place and culture", i.e. a correspondence in development between the two, was at any rate prevented by the social engineering of the apartheid regime. Racial segregation infringed all aspects of life from the national (e.g. the homeland policy), and the urban (e.g. the allocation of the population to specific residential areas according to their racial classification) through to the social level of people's lives (e.g. the prohibition of mixed marriages) (Nopens 20). Particularly the forced removals of people living in the multicultural inner-city hubs of Sophiatown or District Six, to name but two of the most prominent sites of removals, prevented this isomorphism of place and culture for whole communities. More importantly, race continues to be the dominating feature of postapartheid social reality and governance even if under slightly different auspices. A drastically changed political sphere which is under firm 'black control' may characterise South Africa since the ANC's ascent to power, but for the majority of South Africans the economic conditions remain largely the same. While wealth can be considered as partially deracialised, not least due to a growing black middle class in connection to the ANC's Black Economic Empowerment policy, poverty is still strongly racialised and the black population remains most severely affected by it (Bundy 49). Upward mobility has thus become an even more dense and politically loaded entanglement of race and class.

This is where Massey's concept of the "power-geometry of space-time" takes effect. According to Massey, social interrelations and interactions are 
"full of power and symbols, a complex web of relations of domination and subordination, of solidarity and cooperation" ("Politics" 81), i.e. 'powergeometries of space-time', which she defines as follows:

For different social groups and different individuals are placed in very distinct ways in relation to these flows and interconnections [i.e. to time-space, to social relations, and interactions]. This point concerns not merely the issue of who moves and who doesn't, although that is an important element of it; it is also about power in relation to the flows and the movement. Different social groups have distinct relationships to this anyway-differentiated mobility: some are more in charge of it than others; some initiate flows and movement, others don't; some are more on the receiving end of it than others; some are effectively imprisoned by it. ("Power-Geometry" 61; original emphasis).

In their most obvious and general form, such power-geometries are visible in the architectural shapes of South African metropolises. Urban property development has been, and continues to be, market-oriented rather than sociallyoriented, with the consequence that property developers will continue to furnish architectural infrastructures for the wealthy, such as costly housing and extravagant shopping malls. Historian Colin Bundy, for example, states that "[ $t$ ]he love affair between the suburbs and the motor car remains intense, and the new highways shuttle people between separate spheres of work, leisure and home" and South Africa's many malls are, and will continue to be, "purpose-built" for the country's affluent as he poignantly adds (104). Furthermore, while South Africa's middle and upper class have easy access to these shopping malls in their private cars, the financially less fortunate are dependent on minibus taxis. This binds them to the taxis' schedules and travelling routes. The minibus taxi fares may be affordable, but they nevertheless put certain financial restrictions on those who are dependent on them. Possible changes of taxis since there might not be a direct route to the desired shopping mall add further financial strains. The situation is further complicated by the fact that leisurely shopping outside shopping malls is rare in South Africa. Both aspects add to the spatial marginalisation of South Africa's economically less privileged.

\section{From Space to Place}

In accordance with her conception of space, Massey defines 'place' as:

a particular articulation of those relations, a particular moment in those networks of social relations and understanding [...]. But the particular mix of so- 
cial relations which are thus part of what defines the uniqueness of any place is by no means all included within that place itself. Importantly, it includes relations which stretch beyond - the global as part of what constitutes the local, the outside as part of the inside. (Space, Place and Gender 5)

Similar to space, place thus also has a distinctly fleeting and thus dynamic aspect; it is under constant change. Additionally, place is not delimited by its boundaries, but in conversation with them. Furthermore, it is in constant exchange with the outside. This then opens up the question of the subjectivity of a place and (people's) subjectivities more specifically. In the broadest sense, subjectivities are established as a consequence of the effects that social interrelations and interactions have on both place and individuals in that place. It is here that notions of 'home' or the 'home-place', to use Massey's term, come into effect.

In Space, Place and Gender, Massey describes the twentieth century - and I would argue that this is still true for the twenty-first century - as shaped and influenced by a series of profound transformations, the transitions from modernism to postmodernism or from colonialism to postcolonialism being only two examples thereof (157). In the South African context, for instance, one can add the historically monumental transition from the apartheid to the postapartheid era as a further significant example. Massey argues that the frequent use of the prefix 'post' in describing the constant changes the world economy brings about are a sign of "the prevailing uncertainty about the positive shape of the new" (157) within a meta-narrative that is generally unified under the cover of globalisation (158). Due to this ambiguity, the notion of 'home-place' - a concrete space, a particular set of relationships and interrelations, that is imbued with meaning (and, ideally, linked to feelings of comfort, security, and stability) - becomes increasingly important as counterweight to "the new complexities of the geography of social relations" and the growing sense of "fear and anxiety [of disorientation and a sense of loss]" that they trigger (172).

The revitalising initiatives (RIs) for Cape Town's central business district (CBD) offer an excellent example of what could be called 'subjectivity branding' of a place and the type of fears and anxieties they fuel. ${ }^{7}$ A wide range of strategies have been implemented in order to overcome the CBD's reputation as a dangerous and dilapidated place, but of particular interest are the adop-

7 For an overview on RIs in Cape Town see Dewar; or Pirie, "Reanimating". 
tion of city improvement districts (CIDs). ${ }^{8}$ CIDs are zones within the city that profit from privately funded additional security, cleaning facilities, and marketing support with the overall aim to further Cape Town's establishment as a 'world-class city'. In this regard, the removal of informal traders from sidewalks within CIDs, for example, remains a particularly controversial issue. A thorn in the flesh of formal businesses, informal trading is the basis of livelihood for many of the lower economic classes. Nevertheless, the CBD's 'branding' as an "aestheticised commodity" (Mbembe, "Aesthetics" 54) in pursuit of investors and tourists ultimately outweighs concern for the informal traders' livelihood (Miraftab). ${ }^{9}$ Ultimately, CIDs and their endeavour to 'improve' economically profitable urban districts to further the city's 'international image' are a further example of power-geometries at play to the disadvantage and spatial marginalisation of South Africa's lower economic classes. Cape Town is thereby by no means an exception. Such RIs are a common feature of South Africa's principal cities and can also be found in Johannesburg (Bremner) and Durban (Grest).

Overall, Massey's concept is thus not only a way to unite Nuttall's and Mbembe's topographical 'mapping' of the post-apartheid city with Nuttall's topological reading thereof, but such a procedure results in a type of inventory of (imaginary) power-geometries. Such an inventory in turn provides an insight into possible causes for, and transformations of, these (imaginary) power-geometries as well as different coping strategies to withstand and circumvent these power-geometries. Finally, it is on the basis of such an inventory that a cross-city comparison (Nuttall's regional variations) can be conducted.

\section{DURBANITE AND CAPETONIAN URBAN STUDIES}

Johannesburg may have been the starting point for a more systematic reembedding of South Africa into urban theory as well as a more comprehensive analysis of various underrepresented cultural archives, but such endeavours have not passed by scholarly activity on South Africa's other two major metropolitan centres: Durban and Cape Town. Both cities feature prominently in David M. Smith's edited volumes Living Under Apartheid and its companion The Apartheid City and Beyond, published in 1982 and 1992, respectively. In a survey article from 2005, Gordon Pirie gives an overview of the hundreds of

\footnotetext{
8 See Miraftab for more on CIDs.

9 On the connection between this 'branding' and tourist imaginations see Bickford-Smith, "Creating a City".
} 
books, book chapters, journal articles, and theses produced on the city of Cape Town across different disciplines between 1990 and 2004 ("Researching"). Doubtlessly, many more have been added since. Of particular interest to my study is the research output of the Department of Historical Studies at the University of Cape Town where scholars have conducted research on various themes of the city's history that resulted in, among other things, a number of book publications. ${ }^{10}$ The work of Vivian Bickford-Smith, who according to Pirie is among "the ten most frequently published authors" between 1990 and 2004 ("Researching" 341), and his colleagues Elizabeth van Heyningen and Nigel Worden has to be mentioned here. Their co-authored books Cape Town: The Making of a City (Worden et al.) and Cape Town in the Twentieth Century (Bickford-Smith et al.), published in 1998 and 1999, remain the most comprehensive overview of Cape Town's history from its beginnings through to the height of apartheid. Bickford-Smith is furthermore the author of Ethnic Pride and Racial Prejudice in Victorian Cape Town, published in 1995, where he shows how Cape Town transformed from a colonial town to a modern city at the end of the nineteenth century and how the mineral revolution and the resulting increase in population changed the attitudes towards the city's growing number of non-white inhabitants, thus marking the beginning of the city's segregation policies. In The Emergence of the South African Metropolis, published in 2016, Bickford-Smith looks at all three major South African metropolises (i.e. Johannesburg, Cape Town, and Durban). He is interested in, among other things, "how perceptions of cities or discrete areas within cities contribute to creating or reinforcing social identities like nationality, ethnicity, race and class" (6). The work by Bickford-Smith and his colleagues is of particular interest as it partly reverts to literary texts as historical sources. Bickford-Smith reminds one how "[i]ndividual cities and city spaces have been represented in fictional formats like novels, feature films and poetry as well as ostensibly non-fiction social surveys, guidebooks, travel writing, city histories, select committee reports and documentaries" and contends that "representations of any kind generally reflect contemporary social attitudes to a particular urban place or to the urban in general [and] might in turn help shape or maintain those attitudes, and thereby contribute to conveying a place's identity to both visitors and residents" (The Emergence 10). It is here then that Italo Calvino's conception of the city as "a rebus [...] of desires and fears" takes its full effect (44). Literary texts consequently can be seen as "condensed artistic means of ad-

${ }^{10}$ For an overview of up until the last turn of the millennium see Bank and Minkley's editorial to the 1998/1999 special issue of Kronos. 
dressing and expressing socio-historical facts and societal change", a reflection of "individual and public conflicts, both past and present" that generate "dreams deferred or, rarely, fulfilled and develop utopian/dystopian 'alternative scenarios' to (seemingly) deadlocked situations", as I have argued elsewhere, together with Alan Muller and Lindy Stiebel (Introduction 10). As a representative of literary scholarship, Meg Samuelson's work, to which I will repeatedly make reference throughout my study, shall be flagged here. Her more recent work looks at water and the sea as a literary trope to think through the continuity of Cape Town's history from its initial settlement by the Dutch East India Company through to the neo-liberal post-apartheid city as represented in a range of post-apartheid literary texts ("Oceanic Histories", "Sea Changes", and "(Un)Lawful Subjects").

The city of Durban has also generated a prolific amount of scholarly literature. Bill Freund and Vishnu Padayachee, in their 2002 interdisciplinary volume of essays, (D)urban Vortex, claim Maynard W. Swanson's 1965 PhD “The Rise of Multicultural Durban: Urban History and Race Policy in South Africa 1830-1930" to be "a foundation stone on the emergence of South African urban history" (5). One also has to mention Paul Maylam's and Ian Edwards' 1996 edited volume The People's City: African Life in Twentieth-Century Durban that brings together contributions on Durban's economic history, labour struggle, and social issues, as well as Rob Pattman's and Sultan Khan's edited volume Undressing Durban: Behind the Tourist Gaze from 2007, which pools a vast number of contributions on topics of a sociological nature such as street children, HIV/AIDS, and sex work in and around Durban's harbour. Of particular interest to my study is also the rich documentation of the history of Durban's Indian population in such works as Bill Freund's Insiders and Outsiders: The Indian Working Class of Durban 1910-1990, published in 1995, Ashwin Desai and Goolam Vahed's 2010 Inside Indian Indenture: A South African Story 1860-1914, Hélène Mainet-Valleix's 2002 book Durban: Les Indiens, leurs térritoires, leur identité, or the 2013 volume The Making of Place: The Warwick Junction Precinct: 1870s-1980s, edited by Leonard Rosenberg et al. These scholars' works proved to be indispensable with regard to my analysis of the short story collection Flat 9 by the South African-Indian author Mariam Akabor in Chapter 1.1. The University of KwaZulu-Natal, Durban, furthermore, launched a comprehensive project in literary tourism in 2002 that has continued to expand since then (KZN Literary Tourism). The project culminated in the publication of $A$ Literary Guide to KwaZulu Natal (McNulty and Stiebel), which was published in 2017 and brings together the project's achievements of the past fifteen years. 
According to Lindy Stiebel, the project's initiator and director, the project had:

a threefold purpose involving firstly, the creation of a literary archive of local writers both past and present; secondly, the recording of selected writers and their works on film, and thirdly, the establishment for locals and visitors alike of routes which bring together writers and the places about which they write a literary map of the region. ("Hot Spots" 34) $)^{11}$

The third objective proves especially interesting with regard to my analysis of spatial representations and shifting subjectivities in a selection of fictional texts. Literary tourism works precisely at the interface of space (or rather place) and identity formations, although from a slightly different perspective than I intend to take in my study as it seeks to establish and document a specific author's relations to a particular place. The various literary trails of the KZN literary tourism project proved to be a fruitful starting point in my search for possible texts as the thematically pooled analysis of the project's literary archive is still in its beginnings. ${ }^{12}$ Mariam Akabor, whose short story collection I analyse in Chapter 1.1, as mentioned above, features among the so-called 'Grey Street Writers'. Among the writers of fiction listed in the Grey Street Literary Trail, Imraan Coovadia's and Aziz Hassim's work have attracted the greatest scholarly interest, ${ }^{13}$ which leaves Akabor's work, for example, underresearched.

While both Cape Town and Durban have generated a great number of scholarly outputs within the broader field of urban studies, there are not only surprisingly few cumulative approaches to the analysis of city literature in South Africa, there are also almost no comprehensive cross-city analyses of urban spaces in fictional works. Shane Graham's book South African Literature after the Truth Commission: Mapping Loss from 2009 is a rare exception that offers such a cross-city analysis. Taking the Truth and Reconciliation Commission (TRC) as "the opening chapter in the vast, ongoing process of transfor-

\footnotetext{
11 See also Stiebel "Pilgrimage" and "Last Stop".

12 The project has generated eight trails in total: The North Coast Writers Trail, the South Coast Writers Trail, the Midlands Writers Trail, the INK (Inanda, KwaMashu, Ntuzuma) Writers Trail, Paton's Pietermaritzburg, the Cato Manor Writers Trail, the Rider Haggard Literary Trail, and the Grey Street Writers Trail ("Trails" and McNulty and Stiebel, A Literary Guide).

13 See e.g. the 2016 special issue of Current Writing, edited by Ronit Frenkel; Mamet's "Fictional" and "Re-Constructing"; Govinden's A Time and "Healing"; Muller's "A Handful" and "Cosmopolitan Criminality"; for an overview on Grey Street writers see Stiebel, "Last Stop".
} 
mation" (3), Graham seeks to unearth "new forms of literal and figurative 'mapping' of space, place, and memory" (2). The second part of Graham's study focuses on urban spaces as represented in a selection of what he labels "the new urban literature" (19) and analyses Achmat Dangor's Bitter Fruit, Ivan Vladislavić's The Exploded View, K. Sello Duiker's The Quiet Violence of Dreams, and Aziz Hassim's The Lotus People. According to Graham, these texts "all engage in peripatetic archiving and narrative mapping that can both decode and obscure spatial inscriptions of memory" (18). With his selection of texts, Graham is an unusual example of a study on all three major South African metropolises, even if the actual focus is primarily on the TRC and the analysis of urban spaces seems to be more general than specifically comparative.

Like Graham's study, my analysis of fictional(ised) representations of Durbanite and Capetonian urban spaces in a selection of post-apartheid literary texts has a similar cross-city approach and focus on the interrelation between spaces and identities. My focus on the cities of Durban and Cape Town results from the fact that the analysis of the two cities' literary representations has, in comparison to Johannesburg's, received less scholarly attention. This corresponds to the two cities' "perceived national importance", as Stiebel argues, according to which "Johannesburg is the economic powerhouse, an urban edgy metropolis; Cape Town is the tourist destination, a geographically beautiful city with a cosmopolitan, even 'European' feel; Durban is the Cinderella city - subtropical, slower, spread out" ("Nkosi's Durban” 227). In contrast to Graham, however, my analysis does not take the TRC as its point of reference and my choice of texts deliberately falls on internationally lesserknown South African writers as well as a number of first works by South Africa's younger generation of writers. I see the texts by Mariam Akabor, Rozena Maart, Johan van Wyk, K. Sello Duiker, Bridget McNulty, and Lauren Beukes as a valuable counterweight to internationally long-established and renowned South African writers such as J. M. Coetzee, Nadine Gordimer, André P. Brink, or Athol Fugard. To foreground the former, however, does in no case imply that the latter have lost in value. It is much more a means of taking into consideration new perspectives on South Africa and thus "some of the shifting parameters of narrative interest and preoccupation in the country" (Nuttall, Entanglement 93). Three of the six authors I have selected for my study (i.e. Lauren Beukes, Rozena Maart, and K. Sello Duiker), furthermore, have either won or been shortlisted for one or more renowned literary prizes. The other works inclusion is justified on the basis of the texts' intrinsic interest. Mariam 
Akabor's Flat 9 is, as mentioned earlier on, listed among Durban's so-called Grey Street writers, where she features as one of two younger authors alongside Imraan Coovadia. It is the short story collection's critical stance towards South Africa's Indian population, particularly with regard to the depiction of intergenerational conflicts, that warrants the text's consideration for my study. Johan van Wyk is a renowned Afrikaans poet whose first work of prose, Man Bitch, caused quite the public uproar upon its publication in 2001. The relentless tale of an Afrikaans professor's sexual escapades with a number of black prostitutes offers deep insights into the psycho-sociality of post-apartheid South Africa and the problems at heart in the country's new dispensation. Ultimately, the text's problematic premises beg for its inclusion, especially because of their continuing relevance in view of the 2015/2016 student protests and the racial debate they (re-)issued. Bridget McNulty's Strange Nervous Laughter, finally, merits being included due to its uniqueness. With its amusing and magically tinted nature, the novel offers an unusual take on postapartheid society. Its publication both in South Africa and in the United States, a privilege that is usually reserved for the country's literary 'big guns' of the likes of Lauren Beukes and Sarah Lotz as well as internationally bestselling crime authors such as Margie Orford or Deon Meyer, further speaks to the novel's popularity around the time of its publication.

\section{SOUTH AFRICAN LITERATURE ‘BEYOND 2000’}

All six texts I focus on have either been published in 2000 or later, a time which, according to Michael Chapman, has seen, both quantitatively and qualitatively, a departure from the country's literary output of the 1990s. Chapman argues that after 2000, South Africa entered "a phase in which books tangential to heavy politics, or even to local interest, have begun to receive national recognition" ("SA Lit" 1). In this regard, Leon de Kock argues that the number of publications has grown exponentially since 2000, making it increasingly difficult to keep abreast of contemporary South African fiction ("Notes" and "The End"). In her discussion of a whole range of debut novels published since 2000, Margaret Lenta furthermore observes how authors of this new phase have broadened the understanding of 'South Africanness' by addressing formerly 'tabooed' topics such as intercultural and same-sex relationships or the marginalisation of women, thus "demonstrate[ing] a general awareness of new freedoms and new developments in South African society, as well as at times registering disappointment with the new regime" (50). Lenta sees these 
texts as predominantly concerned with the following six thematic fields: (1) 'previously silenced communities', (2) 'sex and gender', (3) the 'mixture of languages' as a typical characteristic of the works of black South African authors, (4) a 'writing back' to earlier works of the South African literary scene, (5) the 'roman à thèse' that circles around a distinct topic to such a degree that the text "becomes a fictionalised argument", and (6) an element of 'fusion', i.e. literary texts reflecting "the fact that people of different ethnic communities are now free to know each other outside of their work and to form what ties they wish" (53). It is the openness of the thematic fields that constitute one of the strengths of Lenta's approach, as it does not restrict individual texts to a single field but accounts for thematic crossovers. K. Sello Duiker's Thirteen Cents, which I discuss in Chapter 3.2 for example, does not only break the topical taboo of homosexuality, male prostitution, and mental illness (Demir et al. 31 ), but is at the same time of a multilingual character and, in view of its relentless depiction of the life of a street child, concerned with a previously silenced community. Indeed, Lauren Beukes' debut Moxyland, which is the focus of Chapter 3.2, can to a certain extent be considered a roman à thèse that is concerned with the downsides of post-apartheid Cape Town's hyperreal corporate world and neo-liberalist consumerism and its spiralling negative effects on post-apartheid subjectivities.

Besides the label of 'SA Lit beyond 2000', which is meant to account for "South African Literature in the transnational moment, 'transnational' denoting the nation caught in movement - possibly transformational movement 'in-between' local and global demands" (Chapman, "SA Lit" 1), the terms 'post-TRC fiction' (Akpome; Graham), 'post-post-apartheid literature' (Chapman, "Conjectures"), 'post-transitional South African literature' (Frenkel and MacKenzie, "Conceptualizing"; Samuelson, "Walking"), or the 'extended transition' (Bystrom) have been used to account for the changes within postapartheid literature at large. Interestingly, the same definition Chapman uses for his and Margaret Lenta's temporal label of a 'South African literature beyond 2000' - which, as mentioned above, Chapman sees as less politically involved and no longer solely concerned with South Africa - he uses elsewhere for what he then labelled as 'post-post-apartheid literature'. He argues that, in his later work, J.M. Coetzee, for example, "appears to have moved beyond his traumatised vision of his home country: that is beyond Disgrace" ("Conjectures" 2). Despite such seemingly stark changes, Chapman contends that much of South Africa's literature in this new phase still bears strong concerns 
with the country's apartheid past. He argues, however, that the term postpost-apartheid suggests a greater distance to that past. ${ }^{14}$

Ronit Frenkel and Craig MacKenzie argue in favour of the 'posttransitional' as a label for the country's literary output of the new millennium ("Conceptualizing"). According to Aghogho Akpome (41), the term 'posttransitional' was first used by Meg Samuelson in 2008 ("Walking"). In her article, Samuelson states: "A question of what we may call 'post-transitional' writing, then, is whether it may advance a recognition of the imbrication of public and private, and of the unhomely spaces that ensue [...]" (131-132). Samuelson may not give "a formal and comprehensive theorization" of the term, as Akpome claims (41), but she nevertheless provides a definition of sorts. Samuelson sees the post-transitional as a new period within South Africa's new dispensation in which "'rainbow nationalism' increasingly drops its variegated visage in order to reveal its deathly xenophobic face" and where "[t]he discomfiture or sense of stasis entailed in inhabiting the transitional margin is met by a desire to move on - to enter into a post-transitional state in which to create new structures of intimacy" ("Walking" 133, 134). One might regard Samuelson's definition as 'rather loose', but this is probably due to the fact that the article does not primarily target the coining of a new term to account for the changes within the post-apartheid literary production. Samuelson's scepticism towards the concept of the post-transitional and warning that "we may risk over-categorizing what remains an emergent, amorphous body of work" ("Scripting Connections" 113) in her response paper in Frenkel and MacKenzie's 2010 special issue of English Studies in Africa corroborates this conclusion.

Similar to Graham, Frenkel and MacKenzie see the end of the TRC as heralding the start of a new phase in South African writing ("Conceptualizing" 4). They maintain that post-transitional writing, while it may still reexamine the country's past, seems to be less constrained by its apartheid past and may even wholly disregard it. In addition, post-transitional writing is, according to them, more open to, and freer in its use of, humour and satire as well as genre crossing (2). They do not, however, see these characteristics as "unique to the present moment of South African literature" but as "so dominant in the present [...] that the hallmarks of apartheid-era literature - 'protest-style writing', literary realism, moral earnestness, the dominance of race, predictability - have largely been swept aside" (2; original emphasis).

14 Chapman also uses this argument in his preface to the edited volume SA Lit Beyond 2000 (vii). 
Protest writing certainly was a form of writing typical of the apartheid era. This type of writing was, to a certain extent, more concerned with political content than literary innovation and was thus characterised by a high degree of predictability. ${ }^{15}$ The fiction of democratic South Africa, in contrast, is anything but predictable, both in form and content, and engages with its apartheid past in new, original artistic ways. Its disavowal of the country's apartheid past, however, is not as definite as Frenkel and MacKenzie may want us to believe. Mariam Akabor's Flat 9 and Rozena Maart's Rosa's District Six, the two texts I analyse with regard to their uses of (post-)apartheid nostalgia for example, are inextricably linked to the country's apartheid past. More recent texts in which the notion of nostalgia is similarly important are C.A. Davids' The Blacks of Cape Town and Nadia Davids' An Imperfect Blessing. All of these texts, furthermore, are committed to literary realism which is still a thriving genre, despite the spike in speculative fiction by authors such as Lauren Beukes, Luis Greenberg, S.L. Grey, Charlie Human, Sarah Lotz, Lily Herne, and Henrietta Rose-Innes, to name but the most prominent examples. The two seemingly opposing genres of literary realism and speculative fiction both equally contribute to the understanding of changing/changed social realities within post-apartheid South Africa. While literary realism can be seen as a 'fictional(ised) stocktaking' of particular historical circumstances, speculative fiction, one could argue somewhat crudely, deals with alternative outcomes or projections of potential futures, both desirable and unwanted. It is also difficult to see post-apartheid literature as largely depleted of moral earnestness as Frenkel and MacKenzie seem to suggest. Johan van Wyk's novella Man Bitch, K. Sello Duiker's Thirteen Cents, or Lauren Beukes' Moxyland may be of a sexually explicit nature (e.g. van Wyk and Duiker) and/or may contain morally questionable characters (e.g. the protagonist in Man Bitch, Gerald and Allen in Thirteen Cents, and Toby in Moxyland). The ethical deficiencies these novels depict, however, serve the purpose of uncovering socio-cultural and -economic shortcomings, among them the continuing dominance of race, which Frenkel and MacKenzie claim to have been largely sidelined in posttransitional fiction. Even if not explicitly addressed, race still plays a predominant role in much of what Frenkel and MacKenzie label post-transitional liter-

\footnotetext{
15 Lewis Nkosi famously lamented the lack of imagination in black South African writing in Home and Exile where he claims that "[i]f black South African writers have read modern works of literature they seem to be totally unaware of its most compelling innovations; they blithely go on 'telling stories' or crudely attempting to solve the same problems which have been solved before" (131).
} 
ature. It is striking, for instance, how Man Bitch and Thirteen Cents are preoccupied with the continuing perpetuation of white normativity. Humour and satire, lastly, have indeed become popular in South African Anglophone literature since 2000 - one thinks of Imraan Coovadia's Green-Eyed Thieves, Niq Mhlongo's Dog Eat Dog and After Tears, or Zukiswa Wanner's Men of the South and The Madams, for example. In their more recent works, however, all three authors have moved away from humour and satire to pursue more serious and politically loaded topics. I am thinking here of Coovadia's High Low InBetween and Tales of the Metric System, Mhlongo's Way Back Home or his more serious short stories, such as "The Warning Sign", "My Name is Peaches", or "Affluenza", in Affluenza, and Wanner's London, Cape Town, Joburg.

One can indeed say that post-apartheid fiction has moved on to pursue new ways of re-imagining the country's past as well as its present and potential future, often in generically innovative and funny ways as Frenkel and MacKenzie claim. The six texts that I analyse under aspects of nostalgia, mental illness, as well as (un)homeliness and hyperreality as distinct manifestations of the 'ustopian' (Atwood 66), however, suggest a continuing engagement with, and importance of, the apartheid past, much more than the concept of the post-transitional implies. While most of the texts I examine offer (more) positive visions of South Africa's post-apartheid present and future, they mostly proffer first steps towards a processing of the apartheid past. In line with Kerry Bystrom and Aghogho Akpome, I am thus sceptical of terms such as the post-post-apartheid or the post-transitional. The apartheid past is still much more significant than terms such as Chapman's notion of post-postapartheid or Frenkel and MacKenzie's concept of the post-transitional imply. In his contribution to Frenkel and MacKenzie's special issue, Chris Thurman poignantly asks: "How can there be such a thing as 'post-transitional literature' (which would imply that we have completed a transition)? Aren't we still in a process of transition from apartheid to something else?" ("Places Elsewhere" 91). Mbembe similarly argues that "[o]ne of the main tensions in South African politics and culture today is the realization that there is something unresolved in the constitutional democratic settlement that suspended the 'revolution' in 1994 but did not erase apartheid from the social, economic and mental landscape" ("Rule of Property"). I furthermore agree with Akpome who calls for a re-evaluation of "contemporary transition in South Africa and indeed in the postcolonial world in general within a broader historical and socio-political framework that includes anti-colonialism, decolonization, postcolonial nation-building, and the increasingly protean nature of social change" 
(48). According to Akpome, such an endeavour demands "awareness of the peculiar intergenerational contexts of late modernity and postmodernity as well as contemporary globalization and the numerous conflicts characterizing postcolonial social change within which modern African nation-states are evolving" and furthermore signifies that "changes within specific spatial and temporal boundaries are never self-contained and must be understood within wider macroscopic contexts" $(48,49)$. Therefore, I will use the more general term post-apartheid literature to account for the apartheid past's continuing importance for, and at times even overshadowing of, the country's postapartheid present and its potential (speculative) futures.

\section{THE STRUCTURE OF THE STUDY}

In what follows I analyse the relation between shifting post-apartheid subjectivities ${ }^{16}$ and urban space (and place) in six post-apartheid works. In each chapter, I compare and contrast two texts, one set in Durban and the other in Cape Town. While the first four analyses focus on particular neighbourhoods (Durban's Grey Street area and Cape Town's District Six in Chapter 1 as well as Durban's Point Road area and Cape Town's Sea Point and Green Point in Chapter 2), the last two analyses concern the two cities more generally.

In Chapter 1 I discuss two short story collections: Mariam Akabor's collection Flat 9 and Rozena Maart's Rosa's District Six. I look at how these two texts use notions of nostalgia in their re-negotiation of subjectivities in relation to Durban's Grey Street area and Cape Town's District Six. While the former neighbourhood still exists, even though no longer as a 'home' to Durban's Indian diaspora as it used to be, District Six fell prey to apartheid's resettlement policies and is one of the neighbourhoods that was levelled to the ground during apartheid. Based on Svetlana Boym's theoretical conceptions, together with more local and psychological discussions of the concept by Leswin Laubscher, David Medalie, and Derek Hook, I show how 'nostalgia' is used as a form to initiate a processing of a lost home, without, however, having to relinquish or becoming entrapped in memories of past times. In particular, it is Akabor's collection which shifts the focus from an older generation to the

\footnotetext{
16 In accordance with Nick Mansfield, I understand subjectivity to be "an abstract or general principle that $[\ldots]$ encourages us to imagine that $[\ldots]$ our interior lives inevitably seem to involve other people, either as objects of need, desire and interest or as necessary sharers of common experience. In this way, the subject is always linked to something outside of it - an idea or principle or the society of other subjects" (3).
} 
needs and problems of a younger generation, showing how the latter opposes the former's apartheid nostalgia while at the same time processing the unfulfilled hopes of the early post-apartheid years in the form of a post-apartheid nostalgia.

In Chapter 2 I discuss Johan van Wyk's novella Man Bitch and K. Sello Duiker's novel Thirteen Cents. Both texts, though in very different ways, are preoccupied with the mad(dening) perpetuation of white normativity and its effect on the two books' protagonists. Taking Michel Foucault's concept of 'madness', which he sees as socially constructed, as a starting point and combining it with both the work of Frantz Fanon as well as the more recent discourse on the continuing importance of race within post-apartheid South Africa by such scholars as Melissa Steyn, Samantha Vice, or Eusebius McKaiser, I show how different forms of madness are used to depict the two protagonists' differing abilities to re-negotiate their subjectivities. The white protagonist in van Wyk's autofictional novella, on the one hand, ultimately fails to reposition himself within the country's new disposition and 'goes mad' because of his increasing white anxiety. Duiker's black protagonist, a street child and child prostitute, on the other hand, is able to put to more creative and successful use the 'space of madness' into which he is driven by the various gangsters who reign the streets of Cape Town's Sea Point and Green Point, as I read the novel's surrealist, apocalyptic ending as a (mental) liberation from postapartheid's mad(dening) power-geometries.

In Chapter 3 I explore Bridget McNulty's Strange Nervous Laughter and Lauren Beukes' Moxyland. Based on Sigmund Freud's concept of the 'uncan$n y^{\prime}$, in connection to its more political or politicised version of the 'unhomely' as suggested by Homi Bhabha, I argue that McNulty's novel is characterised by a spatio-temporal elusiveness in content, form, and genre. This elusiveness not only reflects the general spatio-temporal openness of the new South Africa but also the ambiguities related to a re-negotiation of post-apartheid subjectivities and the differing degrees of success in overcoming the country's apartheid past that ultimately lend the novel a 'ustopian' character (Atwood 66). My analysis of Beukes' debut novel, in contrast, makes recourse to Jean Baudrillard's concept of 'hyperreality' and argues that the novel not only criticises South Africa's neo-liberal and capitalist state system, but more importantly offers a reading of the country as a 'South African Watergate', where the 'ustopian' city of Cape Town becomes a 'ghostly' and monstrous entity that prevents individualism and cements economic and socio-cultural segregation. 
Overall, my analyses could be considered concentric. Based on Massey's concept of power-geometries, my readings circle around a number of recurring themes, which can be outlined by a number of guiding questions: To what extent do the spatial remnants of apartheid's legacy influence the renegotiation of post-apartheid subjectivities? How and in what ways has the perception of the spatial within the South African city changed? Who profits from facilitated processes of mobility? Whose mobility is obstructed? In what ways are processes of mobility facilitated or impeded? What explanation for the facilitation or obstruction of processes of mobility do the fictional texts give? To what extent are sociological and/or geopolitical aspects of space reflected in the narrative structure of the texts in question? Does the analysis allow any conclusions as to repetitive patterns in the representation and the function of the spatio-temporal in the various literary texts at hand?

My readings thereby have a twofold purpose. On the one hand, they focus on the interrelation between subjectivity and the spatial. On the other, they analyse the influence of narrative strategies on the representation of subjectivity and the spatio-temporal within the literary texts. I am particularly interested in social (im)mobility as well as its interrelation with spatial limitations and transgressions. This begs the question of how the cultural topography and topology - i.e. the depiction of a particular social community and its regulating mechanisms - is put into effect in the various literary texts. As a result, the task of a re-construction of the 'mental geography and cartography' in the texts arises. Following this, I will analyse in what ways the characters' interpersonal relationships, their social, cultural, and political tensions, as well as the various coping strategies in response to the latter are implemented in the 'fictional reality'. 


\section{CHAPTER 1: (IM)MEMORABLE PLACES}

[...] in the seventeenth century, nostalgia was considered to be a curable disease, akin to the common cold. Swiss doctors believed that opium, leeches and a journey to the Swiss Alps would take care of nostalgic symptoms. By the twenty-first century, the passing ailment turned into the incurable modern condition. The twentieth century began with a futuristic utopia and ended with nostalgia. Optimistic belief in the future was discarded like an outmoded spaceship sometime in the 1960s. Nostalgia itself has a utopian dimension, only it is no longer directed toward the future. Sometimes nostalgia is not directed toward the past either, but rather sideways. The nostalgic feels stifled within the conventional confines of time and space.

- Svetlana Boym, The Future of Nostalgia xiv.

Nostalgia does not have to be a reactionary sentiment. It does not have to be a hankering after the past and a rejection of the present and the future. There is a way to be nostalgic about the past without forgetting that the struggle against apartheid was just. In fact, to be nostalgic is to remember the social orders and networks of solidarity that made the struggle possible in the first place.

- Jacob Dlamini, Native Nostalgia 17.

In this chapter, I explore the functions of 'nostalgia' in Mariam Akabor's Flat 9 and Rozena Maart's Rosa's District Six. My analysis is mainly based on Svetlana Boym's notion of 'nostalgia', which she understands as "a longing for a home that no longer exists or has never existed" (xiii). Boym traces the origin of the word to the 1688 medical dissertation by Swiss doctor Johannes Hofer. Hofer, who coined the "pseudo-Greek, or nostalgically Greek" term from nostos (signifying 'home') and algia (meaning 'to long for'), used the term to refer to the pathological sadness of Swiss students who moved to another city to pursue their studies, domestic servants who worked abroad, and Swiss mercenaries in foreign service (3). Swiss doctors suggested a whole range of treatments, such as leeches, opium, emulsions, a purging of the stomach, or a return to the Swiss Alps, to remedy the (at least originally) typical 'Swiss illness' (xiv, 4). Since Hofer's dissertation, nostalgia has undergone considerable semantic change. "[T]he early usage", Leswin Laubscher concisely outlines, "changed over time, most particularly away from medical to psychiatric pa- 
thology, and then, in another shift, to an understanding of nostalgia as a widespread, if not universal, and normal emotion" (215).

Following Boym's basic distinction between a restorative and reflective form of nostalgia, which I discuss in detail later on and supplement with more psychological theorisations of the concept where appropriate (particularly Hook; Klopper; Laubscher; and Medalie), I show how in both Akabor's and Maart's short story collections the latter, more critical form is put to use, but with decidedly different aims.

The notion of what I call 'immemorability' will be crucial in working out these different functions of nostalgia. Derek Hook, in his book (Post)Apartheid Conditions, highlights the fact that nostalgia, besides its socio-cultural component, also belongs to the domain of psychology and thus must also be considered "a mode of experience, of memory, indeed, of affect" (177; original emphasis). It is against such a psychological (and philosophical) background that Leswin Laubscher's conception of nostalgia as the (fond) reminiscing of a 'divided' self, to itself, about itself has to be understood (221). Thought of as a distinctly self-referential act, nostalgia, according to Laubscher, is "the impossibility of possibility, the non-condition for all conditional forms of nostalgia. It is what sets all these different understandings of nostalgia [such as advocated by Svetlana Boym and Jacob Dlamini, for example,] in motion, but whose forms are not, and never nostalgia 'itself'" (222).

Hook, in view of this impossibility, highlights, among other things, the "fantasmatic" nature of nostalgia and asks: "If nostalgia, like fantasy, is conditioned, by impossibility, should we not then view it as a fantasmatic formation in the technical sense of an imaginary figuration that attempts to remedy an impasse, to make good on a lack?" (182; original emphasis). Accordingly, Hook posits that "we need to take nostalgia seriously" as it "might be said to possess a diagnostic function: it contains within it an implicit diagnosis of current social ills, along with a potent imaginary loss" (182). And yet nostalgia is no longer a pathological condition but rather an (omnipresent) "incurable modern condition" (Boym xiv), rendering the identification of a clear symptomology practically impossible. There are two reasons for this: Firstly, nostalgia can have different meanings for, and impacts on, different sets of people in different spatio-temporal contexts. Because of its ubiquitous nature, nostalgia takes on an infinite number of possible (individual) forms: This makes a clinically comprehensive understanding of the symptomology of (post)modern nostalgia thus near impossible. Secondly, a clear symptomology suggests a recurring sequence of particular symptoms, which, in turn, implies the possibility to 
predict these symptoms. Such an assumption, however, dismisses those forms of nostalgia which cannot be controlled. For example, one element of nostalgia may be surprise - such as in the case of fond memories triggered by a scent one picks up when walking through the streets. This is what Laubscher calls "the surprise of the nostalgic seizure"; from the Latin surprehendere "to be seized from above, from elsewhere" (sur- meaning 'from above' and -prehendere 'to be seized or grasped') (12). Thus, the diagnostic function of (post)modern nostalgia which Hook posits should rather be understood as the ability of nostalgia to evoke different spatio-temporal trajectories - i.e. the interaction of past, present, and future - and the attempt to understand the different factors that play into the emotional entanglement of time and space. This begs several questions: What is remembered and what is (un)consciously left out? Who remembers? And what implications do these reminiscences have?

Besides these conceptual impossibilities of (post)modern nostalgia, however, one also has to take into consideration a more practical impossibility, namely the impossibility to remember the very past in question. This impossibility arises either because a person has not, or has only in part, experienced a particular space-time or because it is too painful or traumatic to be remembered and has consequently been forgotten (consciously or unconsciously); this I refer to as 'immemorability'. Immemorability, then, as the impossibility to remember, becomes the opposite of 'unmemorability' - in that something is not memorable because it is uninteresting and thus not worth remembering (Oxford English Dictionary). If I talk about (im)memorable places, then, I am interested in two things: (1) the degree of the (im)possibility of remembering a particular (home-)place and (2) the subsequent prognostic and/or remedying component which results from this (im)possibility. This second interest of mine ties in with the conceptual impossibilities of nostalgia discussed above. My discussion of Akabor's and Maart's short story collections will show that immemorability (and in turn the will or necessity to overcome it) can have different origins.

In Akabor's Flat 9, which is set in Durban's Grey Street area of the early 2000s, immemorability is a question of inter-generationally differing attitudes towards the neighbourhood's apartheid past. The short story collection highlights the increasing inability of a younger South African Indian generation to remember the apartheid past which it experienced only partly or not at all. At the same time, this younger generation is constantly confronted with an older generation's reflective apartheid nostalgia. This inter-generational clash results 
in the younger generation exhibiting a reflective post-apartheid nostalgia in opposition to the older generation's apartheid form thereof. This reflective post-apartheid nostalgia is subsequently used as a means to critique the increasing socio-economic and socio-cultural pressures on the younger generation of South African Indians, depicted as afflicted by the burdens of a multiple marginalisation along the lines of their gender, age, and (Indian) culture.

In Maart's Rosa's District Six, which is set in Cape Town's District Six in early 1970, the matter is necessarily a different one. One has to keep in mind that District Six, as opposed to the Grey Street area, does no longer physically exist. While Maart's short story collection also follows the lives of a number of families and a number of characters across different generations, there are two crucial differences in comparison to Akabor's Flat 9. Aspects of memory and (reflective apartheid) nostalgia are a trans- rather than an inter-generational matter. Immemorability is consequently not a question of experiencing a particular (space-)time and the (partial) (im)possibility of memories thereof, but is rather linked to questions of pain and suffering and their effects on processes of memory. The collection, I will argue, not only links nostalgia to a process of mourning, which is prompted by reflectively engaging with both positive and more traumatic memories of life in District Six under apartheid, but also emphasises the ongoing importance of mourning the losses that are a direct result of the apartheid regime.

For formerly oppressed people to have fond memories of apartheid South Africa seems to be a paradox at first glance and, as Hook rightly argues, strikes one as suspect (171). Laubscher, however, reminds one of the fact that in particular socio-historical and socio-political contexts (and post-apartheid South Africa can most certainly be seen as providing such a 'loaded' context), the search for meaning in/through nostalgia "has a clear political and relational effect" (222). This becomes evident in Jacob Dlamini's Native Nostalgia, for example, where the author puts forward that:

[t]o understand the question what it means for a black South African to remember his life under apartheid with fondness is to appreciate that the freedom of black South Africans did not come courtesy of a liberation movement. There were bonds of reciprocity and mutual obligations, social capital, that made it possible for millions to imagine a world without apartheid. [...] black South Africans were present at their making as citizens. Freedom was not sent to them in a gift box from Lusaka. At the same time, this is not to say that every black South African was against apartheid. That would be a lie. (13) 
What Dlamini highlights here is the communal spirit among black South Africans during apartheid and its importance in fostering hopes for a free South Africa. To be nostalgic for the apartheid past is thus to be nostalgic for the solidarity and the communal commitment during apartheid. Dlamini's critical involvement with South Africa's apartheid past and its effects on the country's present (and potential future), is, as I will show, similar to Akabor's and Maart's short story collections (and many other fictional and non-fictional texts), and must be seen as part of what Hook calls a "nostalgic turn" in postapartheid South African culture (170). In view of the past's significance and weight in a large number of post-apartheid fictional (and non-fictional) texts, David Medalie even argues in favour of "a literature of nostalgia" (36). At the same time, however, he warns to keep in mind the varying purposes of nostalgia and advises to be aware of the qualitative differences in these postapartheid texts' applications of the concept. He asserts that "[i]n the majority of cases, the nostalgia is glib, unambitious and utterly lacking in selfconsciousness" (37). Texts such as Jo-Anne Richards's The Innocence of Roast Chicken, according to Medalie, "disown the very nostalgia which they have sketched so vividly because they feel it is incumbent upon them to do so; but the narrative energy is focused to such an extent upon those elements that constitute the nostalgia that it leaves one in no doubt as to the force of its embrace" (37). Works such as Anne Landsman's The Rowing Lesson, in contrast, display a more critical and nuanced engagement with the apartheid past that "recognizes the extent to which the present invests in narratives of the past, as well as the constructedness of memory" (40). Dirk Klopper, with his insightful discussion of Zoë Wicomb's Playing in the Light and its uses of nostalgia, adds another example to this second, more select, group.

My analysis of Akabor's and Maart's short story collections, which I consider to exhibit a more nuanced form of nostalgia, thus adds to the ongoing scholarly discussion of the concept's value in analysing the "cathexis of subjectivity, memory and place" (Klopper 148) as each are concerned with a particular spatio-temporal constellation and its effects on the various fictional(ised) subjectivities involved therein. 


\subsection{MARIAM AKABOR'S FLAT 9}

The Grey Street area, or also Grey Street complex, spans the area from Emmanuel Cathedral in the south to the Greyville Race Course in the north and from the Botanic Gardens in the west to Soldier's Way in the east (Stiebel, "Last Stop" 7-8; Figure 1). Alternatively, the Grey Street area can be counted as part of the Warwick Junction Precinct (WPJ), which Leonard Rosenberg defines as:

the grouping of the Yusuf Dadoo (Grey), and Charlotte Maxeke (Beatrice) Street neighbourhoods, separated by a sport educational and transport zone, from the Wills/Chris Ntuli (Old Dutch) Road residential/commercial neighbourhood. The area is bounded by Greyville racecourse to the north, Botanic Gardens Road to the west, Anton Lembede (Smith) Street/King Dinizulu (Berea) Road in the south and Yusuf Dadoo (Grey) Street to the east, with the centre being the intersection of Chris Ntuli (Old Dutch) Road and Julius Nyerere (Warwick) Avenue [...]. (Introduction 9)

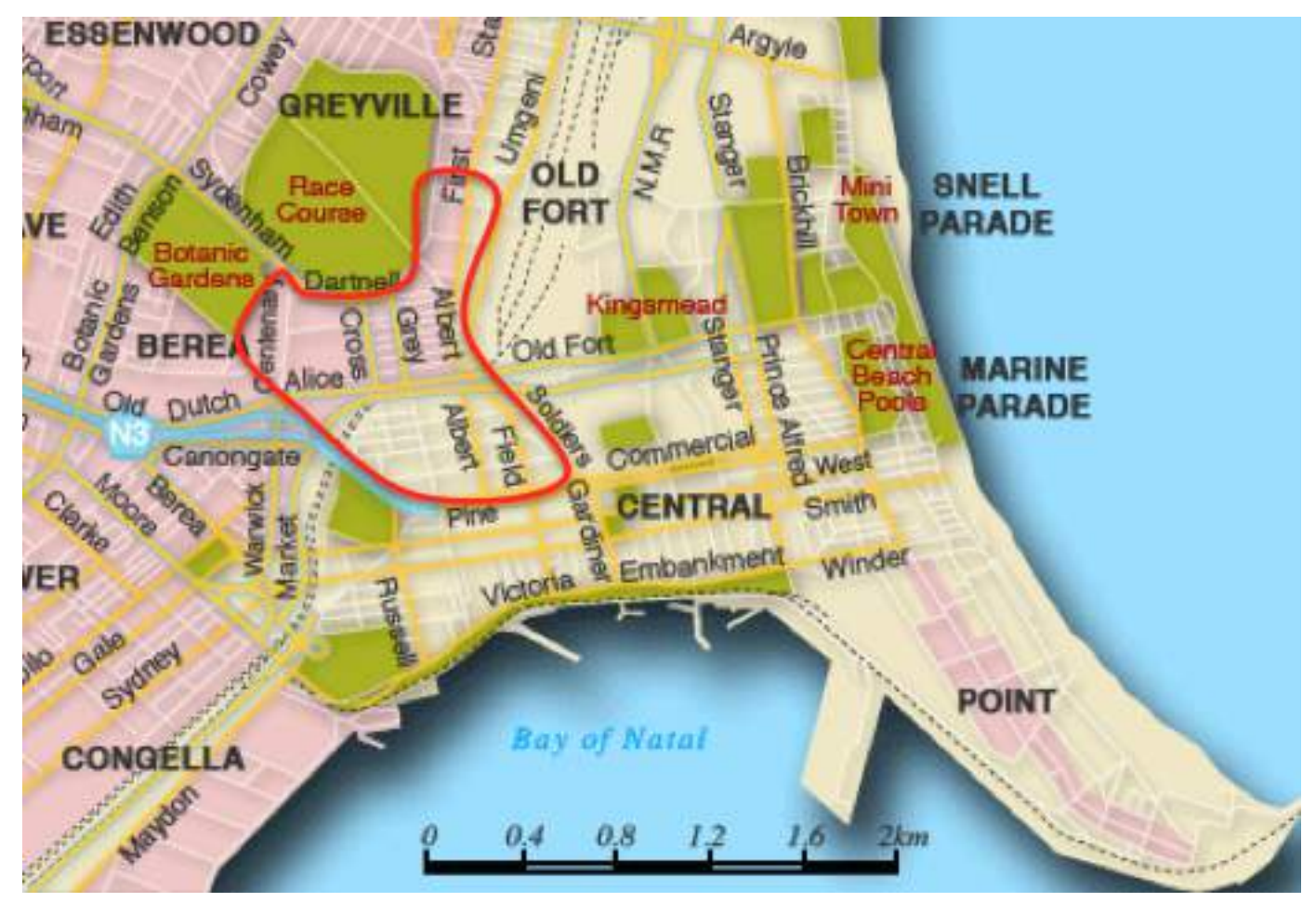

Figure 1: Map of Grey Street Area. 
Although Grey Street was renamed Dr Yusuf Dadoo Street, locals still refer to the (former) commercial main artery by its old name (Rosenberg, Introduction 10). Claudia Mamet, for example, reports that "many Indian writers still refer to the area as 'Grey Street' and struggle to adopt its new name" ("Fictional" 76). On the subject of the Grey Street's name change, Mariam Akabor, in her email correspondence with Mamet, explains:

When I heard about the re-naming of Grey Street I was horrified and sad. I couldn't believe that a street as significant in South African history like Grey Street was being renamed. I felt it as totally unnecessary. You can't erase a part of our history in that way. To this day, I still refer to it as 'Grey Street'. (qtd. in Mamet, "Fictional" 77)

From the 1870s onwards, the Grey Street area became 'home' to 'passenger' Indians and former indentured or so-called 'free' Indians. Indentured Indians, on the one hand, were bound to a five-year contract, mostly as agricultural labourers on the sugar plantations, but also as railway constructors, and mine workers, with the enticement of either a free return to India or the endowment of a piece of land in the Natal province upon the renewal of the contract for another five years (Rosenberg, "Spatial Evolution" 18). Between 1860 and 1911 just over 150,000 indentured workers were brought from India to the Natal Province (Freund, Insiders 3; Rosenberg, "Spatial Evolution" 18). According to Bill Freund, "no unfree labour system was more important than the use of indentured labour, particularly from the vast British domain in India, in filling the gap that existed after the abolition [of slavery]" (Insiders 2). 'Passenger' Indians, on the other hand, were "trading class" Indians who "paid their own fares and came independent of official government arrangements between Natal and India" (Rosenberg, "Spatial Evolution" 18).

The growing number of Indians, who - in stark contrast to Africans were allowed to own and settle on land, and thus became part of the city's economic activities, soon became a threat to Durban's white population (19). The city council consequently took numerous legislative measures in its opposition to the 'Asiatic Menace' (20). The Indian Immigration Law of 1895, for example, imposed a high tax on non-indentured Indians to dam the number of new Indian immigrants and to encourage 'free' Indians to return to their country of origin (21; see also Freund, Insiders 5-6, 11-12). The Public Health Act of 1934 and the Slums Act of 1934, which enabled the city "to clear areas considered as slums" (28), as well as the 'Pegging Act' of 1943 and the 'Ghetto Act' of 1946, which reduced Indian access to land ownership and restricted their 
property occupation (29), advanced the residential segregation of Durban's Indian population. These segregationist policies culminated in the Group Areas Act of 1950 under which 70,000 Indians were resettled within Durban's municipality (35).

The Grey Street area became the focus of the Department of Planning in 1969. The Department's doubts as to whether to zone the area as a White or Indian Group Area came to an end after more than two decades in 1973, when the Grey Street area was declared an Indian Group Area. While the Department's decision allowed trade and light industry in the area, it excluded use of the neighbourhood for residential purposes. This, in turn, meant the relocation of about 12,000 residents from the Grey Street area. Due to the Department's indecision the Grey Street area "had suffered from uncertainty for decades and deteriorated. The loss of the residential component adversely affected not only residents and businesses, but also the residential character of the area" (35).

Given the neighbourhood's turbulent historical background, its inextricable link to the history of South Africa's Indian community, the community's segregation during the apartheid era, as well as the community's resistance against the regime, it is thus not surprising that the narrative of the Grey Street area permeates the writings of the so-called 'Grey Street writers'.

The KwaZulu-Natal Literary Tourism Project drew out the particular historical value of this narrative with their Grey Street Literary Trail (McNulty and Stiebel, "Grey Street" and A Literary Guide), a project which merged the 'real' and 'fictional' or 'fictionalised' aspects of this particular urban space. The trail comprises of both a number of non-fiction writers, such as Phyllis Naidoo, Dr Goonam, Fatima Meer, or Ravi Govender, and writers of fiction, such as Aziz Hassim, Imraan Coovadia, or Mariam Akabor. Tourists can visit landmarks that feature in these authors' writings on a walking tour of the Grey Street area (Stiebel, "Last Stop"). Of the fictional works, Coovadia's The Wedding and Hassim's The Lotus People have been of central academic interest (see e.g. Mamet, "Fictional" and "Re-constructing"; Govinden, A Time and "Healing"; A. Muller, "A Handful"; for an overview see Stiebel, "Last Stop").

Mariam Akabor (b. 1984), who also features among the writers of the Grey Street Literary Trail, was born and raised in Merebank, a suburb located in South Durban ("Mariam Akabor"). Together with Imraan Coovadia, she belongs to the 'younger generation' of Grey Street writers whose writings differ from the activist background of Naidoo's, Dr Goonam's, and Meer's works but share the nostalgic inclinations of Hassim's and Govender's texts (Stiebel, 
"Last Stop" 12-14). Akabor holds a BA in English and Media and Communication from the former University of Natal and an MA in Creative Writing from the University of KwaZulu-Natal, Durban ("Mariam Akabor"). She is the author of a short story collection, Flat 9, and an unpublished novel, "The Muezzin's Daughter", which was Akabor's MA thesis. Together with her husband and their two children, she lives in Durban's Bluff, the southern natural enclosure of Durban's harbour, and works as a part-time doctor's receptionist at her husband's surgery (Akabor, Personal Interview).

The eleven vignettes of Akabor's Flat 9 - "written partly out of stories handed down the generations and also partly from her experience of living in Grey Street in a dilapidated block of flats" owned by an uncle of Akabor's (Stiebel, "Last Stop" 13; Akabor, Personal Interview) - follow the tenants of AK Mansions, a more than a centenary old, decrepit building in Durban's Grey Street. The rich and complicated history of the former, busy Indian CBD interweaves with the bustle of everyday life, creating an agitated backdrop within which the pasts and futures of Grey Street's inhabitants play tug-ofwar with the present.

It is surprising that even though Mariam Akabor's Flat 9 occupies a place among the Grey Street writers, there is no comprehensive analysis of the short story collection. The collection's general nostalgic touch has rightly been highlighted (Mamet, "Fictional" and "Re-constructing"; Stiebel, "Last Stop"). The more fundamental question of how exactly the concept 'nostalgia' is put to use, however, remains unanswered. I am going to argue that in Akabor's short story collection, reflective nostalgia is used as a conscious technique for a critical (re-)construction of the Grey Street area. At the core of this critical (re-)construction there is a fundamental generational clash, which is also connected to a cultural conflict. In entangling the neighbourhood's past, present, and future, the collection critically (re-)negotiates the Grey Street area as a distinctly Durbanite urban space. For my analysis, I will (mainly) take recourse to Svetlana Boym's notion of nostalgia, to which the discussion will now turn.

\section{APARTHEID AND POST-APARTHEID NOSTALGIA IN FLAT 9}

For the literary critic Svetlana Boym, nostalgia is a longing for a (return) home, a feeling of having lost something, of being dislocated, but in part also a dallying with (one's own) fantasy (xiii). According to her, nostalgia is "a defence mechanism in a time of accelerated rhythms of life and historical upheavals" (xiv). Boym's interest thereby lies in the concept's temporal component, as she 
claims that on closer consideration nostalgia is only seemingly a longing for a place and much more a desire for a different temporal perception (xv). Neither directed towards the present, nor (exclusively) the past, nostalgia is a constant negotiation between the past, the present, and the future, albeit not in a traditional chronological understanding of time (xvi). Boym's conception of nostalgia has thus a distinct relational component, which depends on the nostalgic person's mental trajectory, i.e. the focus of his/her spiritual and emotional projection. She argues that "nostalgia tantalizes us with its fundamental ambivalence: it is about the repetition of the unrepeatable, materialization of the immaterial. [...] To unearth the fragments of nostalgia one needs a dual archaeology of memory and place, and a dual history of illusions and actual practices" (xvii-xviii). In this regard, Boym distinguishes between 'restorative' and 'reflective' nostalgia: while restorative nostalgia emphasises nostos, the return home, and suggests a re-creation of the lost, reflective nostalgia stresses algia, the longing and the loss (xviii, 41). Restorative nostalgia, on the one hand, takes itself seriously (49) as it is always truth- and tradition-oriented, totalitarian, and/or national/nationalist (41). Reflective nostalgia, on the other hand, realises and accepts the imperfections in the act of remembrance; it is flexible, individual, and can be critical, ironic, or humorous (49-50). Boym concludes that " $[\mathrm{t}]$ his typology of nostalgia allows us to distinguish between national memory that is based on a single plot of national identity, and social memory, which consists of collective frameworks that mark but do not define the individual memory" (xviii).

This interplay between "social memory" and "individual memory" is also discernible in Flat 9. The following passage is probably the most apparent example of (collective) "social memory" at work in Akabor's short story collection:

'REMEMBER THE OLD DAYS? WHEN MA used to send us to Victoria Street market early in the morning to buy the freshest vegetables and fruit?'

'How Ossie always used to eat something on the way home! Especially the fruit!'

Everybody laughed.

'And how we used to watch movies in Shah Jehan every week? Do you know how your father used to like Dimple Kapadia? Everyone knew he watched Bobby more than ten times at the movies!'

More laughter. (Flat 9 103) 
This is the opening of the collection's second-to-last vignette, "All About the Money" (103-113), which tells the story of seventeen-year-old Firoz, who wants to become a chef, an idea his father firmly disagrees with. The story sets in with the protagonist's parents, uncles, and aunts reminiscing about the past. The dialogue continues as follows:

'We couldn't go to certain benches, only had to live in certain areas. You know that Firoz?' his father asked.

'Daddy, the amount of times you told me those stories, I feel as though I lived it and not you.'

His uncle's laughter boomed through the flat. (104)

While the first excerpt establishes the theme of nostalgia under positive auspices (it centres around fond memories of the past that cause general amusement), the second one highlights the negative facets of the past. It is precisely the confluence of fond reminiscences with more critical memories that constitute what Dlamini calls 'native nostalgia' or what should probably be called an Indian South African version thereof, considering that Dlamini's discussion reviews apartheid history and its effects from a black South African's point of view. Interestingly, the act of nostalgia is thereby located within the older generation. The older generation's fond but critical reminiscences are in stark contrast to Firoz' comment that his father's countless retellings make him "feel as though [he] lived it" in his stead (Akabor, Flat 9 104). This raises the issue of 'postmemories' on Firoz' part, i.e. recollections of experiences "only by means of the stories, images, and behaviors among which [he] grew up" (Hirsch 106). The danger of such postmemories, however, is resolved once the topic is resumed shortly thereafter:

'Firoz, you have an opportunity to go to any university. We didn't have that back in our days. We struggled. It was a difficult life...'

His father began his usual lecture, which Firoz had been hearing from the time he had started high school.

'We all stayed in this two roomed flat and we made do with what we had. Some days we didn't even have uniforms to wear to school because of the rain. Those days we would stay at home,' Uncle Moshin added wistfully.

'So does it mean that I must live your dreams for you? What about my dreams? My happiness?'

'We know what's best for you. We are more experienced,' his father said angrily. 
'Children today, so ungrateful,' Firoz heard his Aunty Ruwaida mutter to his mother. (Akabor, Flat 9 107)

It is the combination of Firoz' reluctance to hear his father's "usual lecture", and his advocating of "[his own] dreams" and "[his own] happiness" with which he distances himself from the adults' (apartheid) memories. The Grey Street his parents, uncles, and aunts remember is an immemorable place for him, i.e. a place that is impossible for him to remember because he did not experience and/or witness it. While the adults' patronising tone towards Firoz is part of the continuous generational conflicts at play in Akabor's collection, to be discussed in detail later on, it is the fact that the older generation acknowledge the irrevocability of the past, as well as the opportunities afforded by the present (as well as the future), which makes them reflective nostalgics. The adults' initial positive, rear-facing view may suggest the concurrent existence of restorative nostalgic tendencies, though this is undermined somewhat by the father's subsequent more critical observations. Overall, the above passages show that restorative and reflective nostalgia "are not to be considered mutually exclusive types, but rather trajectories, tendencies - that often overrun one another - of giving meaning and shape to nostalgia" (Hook 173).

Besides these more overt forms of nostalgia, Flat 9 is full of more indirect nostalgic pockets. One such pocket is the collection's imitation of accents. Time and again, the dialogues are interspersed with little linguistic idiosyncrasies.

Here is temperamental Rashida, a tenant of AK Mansions, shouting after some of the neighbours' children: "'You blurry idjiits! Voetsek fum 'ere! Your mother never thort you manners!" (Akabor, Flat 9 1; my emphasis). And shortly thereafter again: "Whatchu think you looking at? Mine your own bizniss!'” (3; my emphasis).

Or here is part of a dialogue between the 'Dictionary Uncle', a retired teacher living in AK Mansions, and his wife Punniama:

'Why are you so upset Punni?'

'You know Saturdays are my shopping days. Who is goin' to buy veggi-tables now? So late in the day it is! All the fresh veggi-tables will be sold!' (123; my emphasis)

Both examples imitate a stereotypically South African Indian accent. 
And here is an extract of a dialogue between the domestic worker Princess and her employer Zohra Bibi, the former parodying a stereotypically black South African accent:

'Sorry missus. I want to leave air-lee today.'

'I'm not paying you to leave early Princess. Finish washing first.'

'I have to go to, eh, funeral.'

'Funeral?'

'Yes missus.'

'Who passed away?'

'My braa-dha.'

Zohra Bibi looked at straight-faced Princess. 'But your brother passed away last year.'

'That was my big braa-dah.'

'Is he your real brother or your cousin?'

'Missus, all are my real braa-dhas.' (65; my emphasis)

Despite the exaggerated and humorous tones present in this exchange, these linguistic markers can also be seen as an attempt to (re-)create part of the Grey Street area's phonic atmosphere. The situation is, however, not only representative for the animosities between Princess and Zohra Bibi but is also reminiscent of the contention between Durban's black and Indian population, which I discussed in the Introduction.

Another linguistic idiosyncrasy employed to underline the neighbourhood's Indian flair is the occasional borrowing of vocabulary from various Indian languages. Borrowing occurs for individual words such as terms that express familial relations, e.g. Dadi/Dadima (i.e. paternal grandmother) or Nani (i.e. maternal grandmother), or typical Indian dishes like Roti (i.e. home-made Indian bread) or Samoosas (i.e. a savoury triangle-shaped pastry that comes with various fillings, such as potatoes or mutton mince).

Food is a recurring theme in Flat 9 that is closely linked to acts of nostalgia. Its importance is established by the Corner Shop Café, one of the collection's main settings, and its double function as both popular meeting point and eatery:

Apart from the social aspect of the café that people were attracted to, there was one other reason. The bunny chow. Uncle Imoo had gained most respect and money for his unrivalled bunny chows. 
Uncle Imoo had proudly been named the maker of the Best Bunny Chow for a good few years. Framed certificates adorned his walls, as did the numerous newspaper clippings about himself and the Corner Shop Café. (15)

Food is thus inextricably connected to tradition and pride and becomes "the great carrier of diaspora, culture and "home" (Stiebel, "Last Stop" 18). The feelings of home and (be)longing are repeatedly expressed through food. Upon his homecoming after an absence of almost five years, Latif, for example, "sat at the small wooden kitchen table and helped himself to his mother's chicken curry - a dish he'd sorely missed" (Akabor, Flat 9 7). His mother's chicken curry is thus an integral part of Latif's "individual memory" (Boym xviii) of home.

Food is also an essential part of the Friday afternoon tea parties of four lady friends at AK Mansions, where it becomes a symbol for the women's bond of friendship:

Between Hawa Khala, Mrs Bhoola, and Najma, there was an assortment of savouries for tea. Zohra Bibi's task was to make the tea and have the table set whilst the others provided the snacks. Hawa Khala alternated between mince and potato samoosas each week; Mrs Bhoola supplied the vades and bhajias; and Najma did the baking. Zohra Bibi would occasionally make her special homemade pies. (Akabor, Flat 9 35-36)

In accordance with Lindy Stiebel, who argues that "in the detail [...] lies the remembering, the reflective nostalgia" ("Last Stop" 16), it can thus be said that both food and the linguistic markers serve as distinct elements of the "collective frameworks" (Boym xviii) at work in the collection's critical (re-)construction of the Grey Street area.

The use of linguistic markers and the theme of food, however, are not the only strategies put to use to evoke a sense of reflective nostalgia in the short story collection. The nostalgic, according to Boym, has "an amazing capacity for remembering sensations, tastes, sounds, smells, the minutiae and trivia" (4). Flat 9 is indeed full of picturesque passages that transpose the reader into the world of the Grey Street area, both past and present. The sensory wealth of these descriptive passages, to which I now turn in my discussion of the collection's setting, transforms them into further little nostalgic pockets within the neighbourhood's detailed (re-)creation. 


\section{The Grey Street Area in Flat 9}

The eleven vignettes of Akabor's short story collection Flat 9 form a 'time capsule' in which the past, present, and (potential) future of Grey Street overlap. The area's long-standing history and its remnants are thereby reflected in the collection's setting, which mainly consists of AK Mansions and the Corner Shop Café. While both are fictional(ised) places, they can, according to Stiebel, be traced back to Afzal Building on 292 Grey Street and Haribol's Superette on the corner of Grey and Lorne Street, respectively ("Last Stop" 18; see Figures 2 and 3).

AK Mansions, on the one hand, a block of flats which is home to the majority of the characters in Flat 9, speaks to the residential character of the Grey Street area:

The flat was five storeys high and 'EST. 1902' was engraved at the top of the building in stone, indicating its old age. However, that wasn't the only indicator of old age. The paint on the building peeled off inconsistently in layers thus making the building appear with more than one colour of paint. Bright green, pale pink and yellow were the most prominent colours. It was in a devastating state. (53)

At first glance, the building's multi-coloured appearance can be read as a subtle weaving of non-racialist ideals in post-apartheid South Africa into the narrative by means of the collection's setting. It seems to reflect the ideal of abandoning skin colour as a social marker, as the building only "appear[s] with more than one colour". However, the building's apparent multi-coloured appearance can also be read as an indirect critique of the unfulfilled ideals of the 'rainbow nation' and thus suggests the need for a more critical reading of the neighbourhood's past, present, and (potential) future. AK Mansions thus becomes a symbol for the Grey Street area's complex history built-up in a palimpsest-like manner and the flaking painting reveals what lies below the surface. It is as if the dilapidated building itself suggests a nostalgic but nevertheless critical view of the Grey Street area as - as Pierre Nora would call it - a lieu de mémoire, i.e. a place "where memory crystallizes and secrets itself" (7), in order to stop the place from falling into oblivion and preserve its past meaning for the present and the (potential) future (19). 


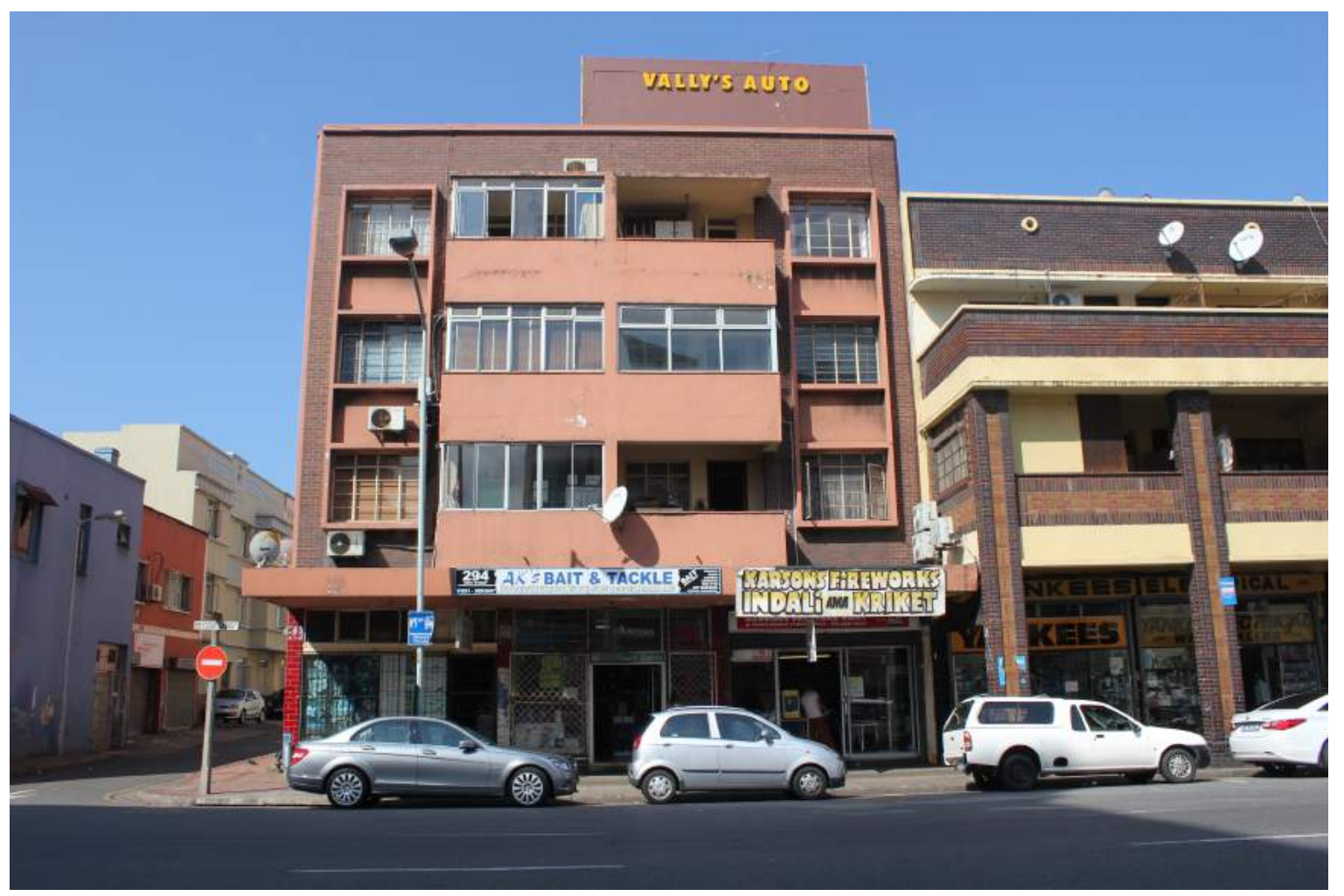

Figure 2: Afzal Building on 292 Grey Street.

The Corner Shop Café, on the other hand, is the neighbourhood's central meeting place:

UNCLE IMOO'S CAFÉ WAS SITUATED AT the corner of Grey Street and Lorne Street. His greatgrandfather was the initial owner of the then tearoom a century ago. The Corner Shop Café was home to the many factory workers in the area; housewives, especially the lazy ones who didn't feel like cooking; the school children who didn't like what their mothers packed for them for lunch, as well as passers-by.

The café was old and had a colonial presence. Even though it wasn't as spacious as the urban cafés, customers didn't mind having to wait for a table. The café exuded a vibrant atmosphere. An aging air conditioner that emitted a jarring sound kept the customers cool. The constant buzz amongst the customers, punctuated by Uncle Imoo's shouting of orders to the staff in the kitchen was perfectly normal. Then there were the regulars, who were referred to as the regs. They were rightly named by the staff since they would visit daily without fail. They sat at the same table every day. (Akabor, Flat 9 14-15) 
Similar to AK Mansions, the Corner Shop Café is an exemplary (architectural) reminder of the area's long-standing history, which stretches back to colonial times. With its multitude of different customers, the café thereby again signposts the area's vibrant flair both past and present.

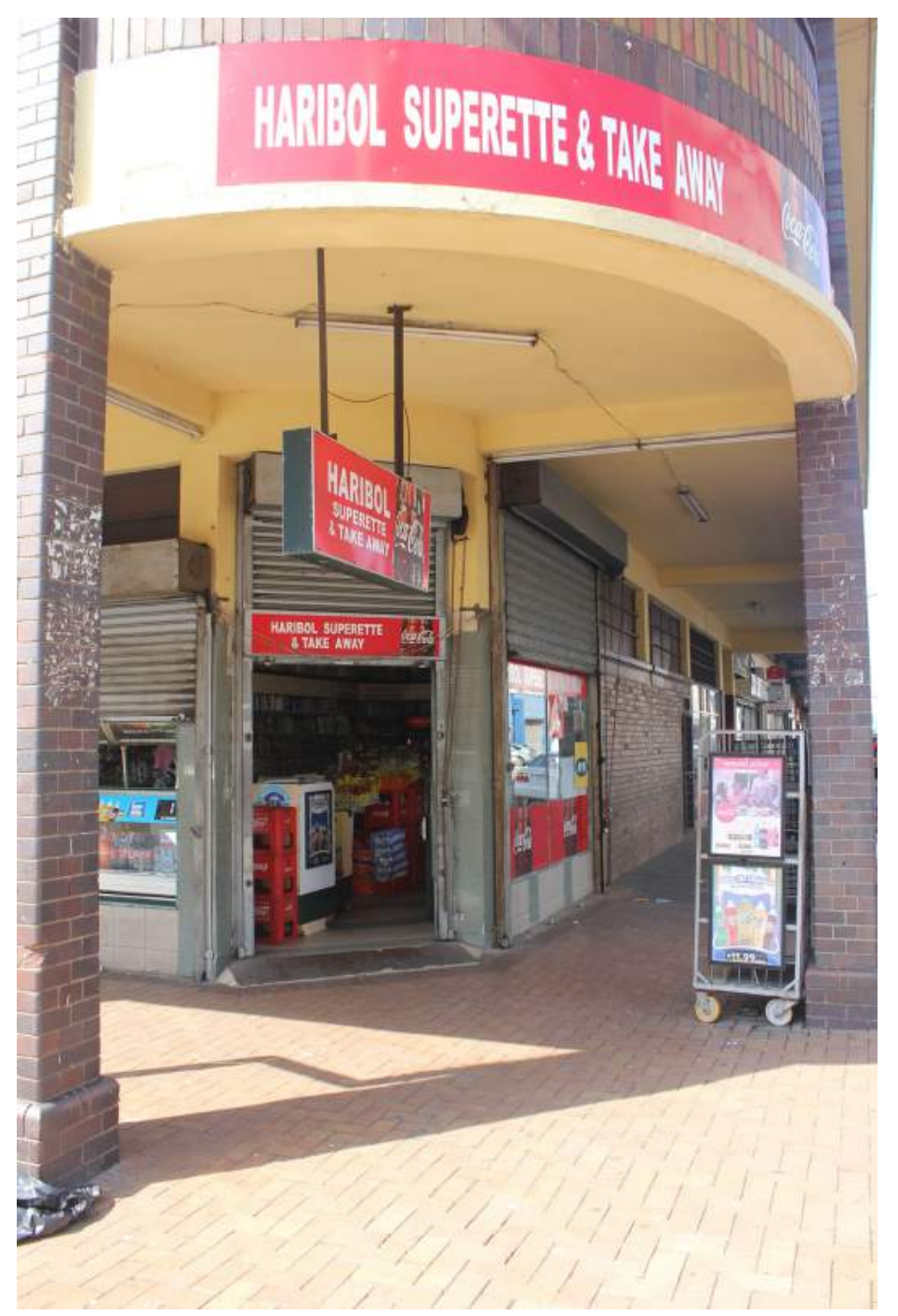

Figure 3: Haribol Superette on the Corner of Grey and Lorne Street.

Both owner of the Corner Shop Café and resident of AK Mansions, Uncle Imoo embodies the neighbourhood's economic and residential components. At the same time, he also becomes the prime example of the neighbourhood's subliminal double standards. During the course of "The Corner Shop Café", the collection's second vignette (14-23), Uncle Imoo has to face a major dilemma when asked for a discount by a new customer. Despite being known for his intransigence on price reductions with his regulars, Uncle Imoo eventually ends up giving the discount, only to be asked for another one on a se- 
cond order for the customer's son who turns out to be a famous local ANC politician. Pulled over the barrel twice, Uncle Imoo consequently becomes the laughing stock of his regulars, not so much for giving the discount in the first place but for flattering the politician when offered the prospect of welcoming the President at his café. Despite all these contradictory qualities of his character, Uncle Imoo becomes one of the defining characters in the short story collection's fictional(ised) (re-)construction of the Grey Street area. In fact, the often unexpected and ironic plot twists are one of the trademarks of the short story collection's (critical) reflections on the area.

Together with the Corner Shop Café, AK Mansions build the basis of Grey Street's social geography. Even though the social order and powergeometries of AK Mansions seem to be impenetrable at first, the first elements of each are established by the vertical hierarchy actualised by the dilapidated, five-story building. The higher up an apartment is situated, the more respected its residents are. This general principle is supported by the fact that the 'Dictionary Uncle', a well-respected, retired teacher who tutors the children of AK Mansions, even if not for the sake of altruism, lives on the fourth floor. Rashida, on the contrary, who is feared and avoided by the residents of AK Mansions, lives on the first floor.

This vertically defined hierarchical criterion, however, is undermined by competing criteria such as a character's influence on the flow of information and the character's commercial success. It is not all too surprising that the two overlap in Uncle Imoo's character:

Gossip exchange was an important part of Uncle Imoo's business. Some of the regs would just stop by to find out what new juicy bit of information was exchanged. Tales of bitter family feud and illicit dealings amongst prominent community members were just some of the topics discussed, and at times, even heartily debated. (15)

Farhaan's case in "The Paki", the collection's fifth vignette (50-63), becomes exemplary for the community's handling of (alleged) "illicit dealings" (15). Uncle Imoo and his wife play a leading role in plotting against the Pakistani immigrant, who is suspected of selling pirated DVDs. Based on her husband's (mis)information about Farhaan's involvement in the distribution of pirated DVDs, Uncle Imoo's wife subsequently (mis)uses her connections to the police to have them give Farhaan a scare. This episode is not only representative of the community's defence mechanisms, but also reflects the power translocation from a vertical to a horizontal element and thus the change and fluidity of 
power-geometries within the community. The horizontal aspect of the community's social geography is further stressed in an element of spatial expansion. Zohra Bibi, the host of the weekly tea party of four lady friends who all live on the second floor of AK Mansions, lives in an apartment that is twice as big as all the others. This (vertical) "extra space" (35) puts her at the top of this four-way constellation from which she pulls the strings and influences the flow of information between the four housewives.

The (implied) reader thus gradually learns about the various characters who live, or plan to live, in AK Mansions, and yet is never able to exactly locate them within the building except for the floor on which they live. On the one hand, this sketch-like characteristic in which the social order of the community is depicted can be viewed as a reflection of the opacity of the powergeometries that shape the community. On the other hand, the depiction of these power-geometries mirrors the collection's overall sketchy structure with its eleven short vignettes.

In "AK Mansions", the collection's third vignette (24-34), the (implied) reader is taken on a 'walking tour' through the Grey Street area. The story circles around Fatima, who works as a shop assistant in (old) Victoria Street. ${ }^{17}$ In order to save the money spent on the daily commute to and from Phoenix, an Indian township northeast of central Durban, she decides to move to AK Mansions, a plan she wants to announce to her mother and brother upon their arrival from Johannesburg. Instead, she learns of her mother's paralysis due to a stroke and is confronted with a fait accompli shortly thereafter, being instructed by her brother to give up her job in order to look after their sick mother. While the story is not directly concerned with aspects of nostalgia, Fatima's walk through the Grey Street area nevertheless implies a reflectively nostalgic aspect in that it 'records' (and subliminally criticises) the area's post-apartheid demographic and economic changes and their (negative) effects on the younger generation.

It is with the collection's upsetting third vignette that the reader plunges into a more 'sensory' experience of Grey Street's distinct Indian/Muslim flair:

THE AZAAN REVERBERATED THROUGH Grey Street, signalling the evening prayer. The sky was cast with a burnt orange glow as the sun gradually disappeared from the horizon. Noisy pigeons flocked to their urban dwellings. Shop owners prepared to leave for home. Some street vendors were busy packing their goods

17 Now Berta Mkhize Street (Rosenberg, Introduction 11). 
in boxes whilst others had already begun folding up their makeshift wooden tables. The queue for the minibus taxis had increased. (24)

The short story's opening evokes an acoustic Durbanite idiosyncrasy. The prayer calls, used as yet another symbol of Durban's multicultural and unique flair, resound five times a day from the minarets of the city's many mosques and seemingly transpose the (foreign) listener to a faraway eastern country. In the case of the Grey Street area, the prayer call furthermore alludes to one of the neighbourhood's most distinct landmarks, the Juma Masjid Mosque at the corner of (old) Grey Street and Queen Street. ${ }^{18}$ The romantically painted sunset, together with the noisily flocking pigeons that parallel Grey Street's bustling late afternoon activities, thereby lends the opening an elated atmosphere that accompanies Fatima's joy about her mother's and brother's imminent arrival.

It is within this joyful atmosphere that the (implied) reader follows Fatima through the neighbourhood's streets:

For the first time in months she had been able to walk leisurely to the taxi rank, pausing to buy fruit from the vendors. Today had been a typical Durban day. The humidity was overwhelming, but that hadn't deterred Fatima from buying fruit for her mother. The street vendors, affected by the heat too, lay limp and only responded when they had to. Those vendors whose stalls were housed in the shade exuded enthusiasm, assuring everyone that their fruit was the sweetest. Some even offered Fatima 'to taste before buying'. (25)

While AK Mansions and the Corner Shop Café offer a more abstract view of the neighbourhood, or what Michel de Certeau would label a more distant or conceptual angle (92; 95), Fatima's "turns [...] and detours" (100) through the Grey Street area bring the reader/observer to the "ground level" (97). It is by means of such a 'close up', de Certeau claims, that a city dweller's relationship with his/her surroundings can be revealed by evaluating people's "walking rhetorics", i.e. their "styles and uses" of walking (100).

While Fatima's stroll through the neighbourhood may evoke the (literary) figure of the flâneuse, which meets her good mood, the leisurely and recreating notion is immediately revoked by the fact that it constitutes an exception for her. The flâneur, the leisurely walker, is doubtlessly one of the most popular literary figures. The trope's popularity, Merlin Coverly pointedly argues, is owed to its "elusive quality, and [its] resistance to easy classification, which is

${ }_{18}$ Now Dr Yusuf Dadoo and Denis Hurley Street respectively (Rosenberg, Introduction 11). 
also apparent in the identity of the flâneur himself (for he is invariably seen as male), a character who has managed to establish a literary history for himself without having fully disclosed his origins" (The Art 153). Despite the ambiguous beginnings of the flâneur, it "remains inextricably linked to the streets of Paris and the poetry of Charles Baudelaire (1821-1867)" (154). The reason for the trope's continuing popularity across academic disciplines, however, is doubtlessly the work of Walter Benjamin (1892-1940), "Baudelaire's most insightful critic" (157). ${ }^{19}$ In her adaptation of the trope to the South African context, Sarah Nuttall observes that the problematic conception of the flâneur as a predominantly male figure up until recently may, in fact, offer new opportunity for scholars to represent "the experience of the flâneuse" (Entanglement 38): Fatima, in Akabor's "AK Mansions", can be seen as a rare South African example of the female counterpart to Baudelaire's flâneur. ${ }^{20}$

It is the exceptionality of Fatima's leisurely stroll through the Grey Street area that evokes an implicit element of nostalgia, her last one dating back months. The reflective element thereby lies in the seemingly stark contrast of the area's current state of affairs and Fatima's memories thereof. Her memory is not 'up to date', so to speak.

Interestingly, this temporal shift is reflected in the weather conditions. The above passage, reminiscent of Bridget McNulty's Strange Nervous Laughter, highlights Durban's hot and humid weather. This sets Durban clearly apart from other South African city's such as Cape Town and its decidedly more volatile meteorological conditions, as depicted in Maart's Rosa's District Six, for instance. However, the city's (sub)tropical climate also creates a slowmotion effect. On the one hand, it is striking how this overall 'speed reduction' reflects Fatima's flânerie, which is opposed to her 'walking style' in the next paragraph. Suddenly time is of the essence and Fatima is forced to walk to the taxi rank "in quick short steps" (Akabor, Flat 9 26) in order to catch the taxi and arrive at home in time. On the other, the heat is another clever stylistic move in support of building up both the Grey Street area's many conflicting characteristics as well as the short story's arc of suspense.

It is through the walking tour, which also turns out to be a (re-)discovery of the area for her personally as well as a covert demographic survey for the (implied) reader, that Fatima is 'brought up to speed':

\footnotetext{
${ }^{19}$ For an overview of the trope see e.g. also Coverly, Psychogeography; or Solnit.

${ }^{20}$ See Alan Muller for a brief discussion of Khateja, the female protagonist of Coovadia's The Wedding, as another example of a South African flâneuse ("A Handful" 187).
} 
Fatima had walked along Victoria Street until she came to Grey Street. On this Wednesday afternoon, it had been busier than usual. She had made her way through the crowds of Grey Street, passing the numerous cell phone shops owned by foreigners and persistent salesmen who shoved their products in your face, urging you to buy them. It was amazing how she had never really noticed all these tiny shops even though she had been working in town for years. (26)

Despite the fact of having walked the streets so many times before, Grey Street still holds surprises for Fatima, as if she had missed the forest for the trees. Fatima's walking experience thus seems to speak to the fact that each new (walking) trajectory entails the potential of discovering previously unknown or unnoticed aspects of a seemingly familiar and memorable place. Such discoveries need not necessarily be positive, but may well be of a more critical nature. The obtrusive foreign salesmen seem to allude to the Grey Street area's changing/changed 'face'. Indeed, many of the formerly Indian-owned or -run shops in Grey Street have been taken over by 'foreigners', as the passage above suggests (see also Rosenberg, "Spatial Evolution" 35). The antagonism between Fatima's negative discoveries and her ostensibly (more) positive memories thereby make the experience an indirect act of reflective nostalgia. Fatima's (subliminal) nostalgia, it should be noted, differs significantly from the one displayed by Firoz' relatives, discussed above. It is not concerned with apartheid times but is restricted to changes in Grey Street since the end of apartheid. What is displayed through Fatima's walk is thus a reflective postapartheid nostalgia, as opposed to the reflective apartheid nostalgia of Firoz' relatives, and it is through this post-apartheid nostalgia that the area's changing/changed 'face' and its effects on the younger generation are revealed.21

The aspect of change is expanded in "The Paki", the collection's fifth vignette (Akabor, Flat 9 50-63), which tells the story of the Pakistani immigrant Farhaan (see also above). Unsuccessful in finding a placement for his postgraduate training, the electrical engineer leaves his home country for the prospect of a better life. Upon his arrival in South Africa he initially works at the takeaway/cell phone shop owned by his cousin's friend, Zafar, in Grey Street. Farhaan's initial experiences in Grey Street are portrayed as follows:

\footnotetext{
${ }^{21}$ I follow Hook in using 'apartheid nostalgia' to refer to (fond) reminiscences of the apartheid past (174-177). By 'post-apartheid nostalgia', in contrast, I mean a younger generation's (fond) memories of earlier times which, due to that generation's partial (im)possibility to (fully) remember the apartheid past, can stand in opposition to an older generation's apartheid form thereof.
} 
Since Farhaan had been working for Zafar on Grey Street when he had first arrived in South Africa, central Durban or 'town' was all that Farhaan got to see. He had no problem with it and made lots of foreign friends, especially those from other African countries. Farhaan soon learnt that there was a vacancy for a barber in one of the salons in an arcade.

This was what he had been waiting for. The previous barber, a South African, had passed away, leaving his loyal customers with no hairdresser. The salon was going to close down but Farhaan jumped at the opportunity. (52-53)

The passage thus not only attests to Grey Street's shifting demographics in post-apartheid South Africa, but with Farhaan's takeover of the barber salon, also reflects the economic changes within the neighbourhood, and, on a microscale, of South Africa more generally.

Even though given advanced warning about the harsh treatment of foreigners in South Africa, his neighbours' xenophobia hits Farhaan with full swing when he moves to AK Mansions. The rumours that 'the Paki' is an illegal 'retailer' of pirated DVDs spread quickly through AK Mansions and the tenants do not hesitate to take action against Farhaan. When his rent goes unpaid after the police threaten him in his salon at the request of Uncle Imoo's wife, the tenants feel vindicated in their suspicions about Farhaan's illegal activities and are convinced that he has left South Africa. What they are unaware of is the fact that Farhaan has actually returned to Pakistan to celebrate his engagement.

Imraan Coovadia's third novel, High Low In-Between, sees its protagonist, medical doctor Nafisa, display a similarly one-sided picture of Pakistani immigrants as a subliminal/hidden (and parasitic) threat that, together with other immigrants from the African continent, is co-responsible for the changing/changed 'face' of the demographic landscape, both in South Africa more generally and Durban in particular:

They had taken over many of these nearby shops because they were willing to work in parts of town where Durban's better-off Indians, not to say the whites, didn't set foot.

The Pakistani's were tough new characters, recent arrivals from the subcontinent. Nafisa knew they were usually in the country without papers. She had only registered their presence in the past year.

Since the advent of the new government nobody enforced the rules on immigration. Unending blocks of Johannesburg were dominated by the Nigerians who moved heroin and morphine from Lagos to Los Angeles. The Senegalese and Congolese were established in Cape Town. Then there were groups of 
Zimbabweans, Mozambicans, others from the Horn of Africa who had served in infantry battalions in Eritrea. But the Pathan Pakistanis were reputedly the toughest.

Nafisa admired them for their severity. They were quite unlike local Indians, having earned a reputation as fierce fighters. They carried short knives under their jackets which she had seen them take out when they felt threatened.

The Pakistanis went everywhere, did everything they wished, and in this way were the freest inhabitants of the country. (16-17)

While xenophobia is thus the major centrifugal force that foreigners must face in the Grey Street area, it is the lack of worthwhile job opportunities that has the same centrifugal effect on locals. This problem is hinted at in the collection's first vignette, "Latif's Mother" (1-13). It tells the story of the temperamental Rashida whose hopes for her son's return are answered on the Saturday morning that the collection begins with. Upon his return, Latif explains to his mother: "I decided to leave Durban on my own. It was not Perumal's fault... I just couldn't take it, living here with so many problems..." (8). His upcoming marriage to a girl from Johannesburg and the opportunity to run his father-in-law's business become the potential routes of escape out of the Grey Street area for Latif and his mother.

In comparison to these two examples of centrifugal forces to the disadvantage of the Grey Street area, Fatima's decision to move to the city centre is made under inverted auspices:

Money had been an issue for her since her divorce. It was costing her a large amount of her salary to travel every day from Phoenix to town and back. That's why she had recently decided to move to town. Rent was cheaper even though the flat that she chose was in a dilapidated building called AK Mansions. She would be able to walk to work. (28)

Fatima's precarious financial situation is thus due to the distance between her workplace in the city centre and her home-place in Phoenix, a condition which is the direct result of the separation from her abusive, drug-addicted exhusband (27). The financial benefits of her move to AK Mansions ultimately outweigh the building's decrepit condition and give the neighbourhood a centripetal force.

Overall, it is striking that these examples of the Grey Street area's centrifugal and centripetal effects, which are the result of demographic and economic changes the area has undergone since the demise of apartheid, are portrayed as primarily linked to the younger generation. It is Fatima's walk through the 
neighbourhood that initially brings these changes to light and criticises them in an implicit act of reflective post-apartheid nostalgia. The fact that the older generation of Grey Street seems to be less affected creates a generational imbalance, with the younger generation being restricted in their social mobility. The divide between young and old can be seen as an interpersonal reflection of nostalgia's central antagonism between the new and the old, i.e. the present and the past. This generational imbalance, however, finds expression not only on an economic level but also surfaces time and again in the form of more personal disagreements.

\section{GENERATIONAL CONFLICTS}

The generational clashes, and with them the opposition of the old and the new/the past and the present, are introduced at the very beginning of Flat 9:

EVERYONE WHO LIVED IN AK Mansions knew that there was going to be hell to pay when Latif decided to return home. His mother had been waiting for almost five years already. Some tenants believed that he wouldn't return at all. With a mother like Rashida, it was understandable that he wouldn't want to come back.

'You blurry idjits! Voetsek fum 'ere! Your mother never thort you manners!' Rashida would be heard yelling every week.

This week was no different. The children scurried down the stairs of the five-storeyed flat laughing themselves sick. Just one look at Rashida every Saturday morning and they would burst into fits of giggles. For they knew she would be doing her weekly 'facial' where she would apply tons of homemade cream. Except for her large round eyes, the gooey green slime would be smeared across her face for an hour. They would creep up the stairs and mock Rashida who didn't believe in shutting her flat door unless she was out. She would be seated on her dilapidated cinnamon sofa directly in front of the television, her chubby feet on a footstool, following up intently on the soap opera repeats. As soon as she spotted the children, she would leap out of her seat and grab her broom from behind the door, shouting and cursing the children, their mothers and fathers, and eventually their grandparents, some of whom were deceased.

Rashida was a short, corpulent woman in her late forties, or so she claimed. No one in AK Mansions in the hub of the city of Durban believed that, of course. She was known for her temper tantrums, exaggerated tales, and loud mouth. No one dared to pick a fight with Rashida for she was too quick in her speech and undaunted in her thoughts and beliefs. (1-2) 
This passage, taken from the collection's opening story "Latif's Mother" (113), is rich in symbolism that mirrors various aspects of the historical, political, and social background of the Grey Street area and its population as discussed above. Rashida's hag-like description is particularly noteworthy: She is portrayed as "a short, corpulent woman in her late forties" (2) and her face is 'distorted' by the green slime of her weekly 'facial'. The latter not only reflects the neighbourhood's changing/changed 'face' mentioned earlier in this chapter, but is also a herald of the 're-make' that is about to happen both in Rashida's life as well as the lives of the tenants of AK Mansions. Discomposed by the children's ridiculing, she grasps her broom and chases after them. It is as if the past (i.e. Rashida) was chasing the present and the future (i.e. the children or tomorrow's generation). When Rashida suddenly faces Perumal, the atmosphere becomes tense. The situation escalates into a proper scandal when Rashida attacks Anuradha, Perumal's wife, after the latter contradicts Rashida. This is the first time Rashida's power is undermined. The fight between the two women can only be stopped by the prodigal son's return. Latif's sudden appearance immediately shifts the power relations, and even disarms Rashida, who is forced to apologise to Anuradha in order to be allowed to move to Johannesburg with her son. In other words, the younger generation prevails over the older one, despite the fact that Rashida's apology is an insincere one at best (the token of reconciliation that she offers Anuradha is a plate of stale biscuits, which "Rashida usually saved for the birds" (11)).

In a way, Rashida's story appears as a time compression of Grey Street's history from the heyday of apartheid to its abolition, as it is reflected in Rashida's unpredictable mood swings and her moving out of AK Mansions at the end of the story. Her departure is thereby all too reminiscent of the forced removals under the Group Areas Act. However, the story also reflects the two sides of the constantly recurring generational conflicts in Flat 9. On the one hand, there is an older Indian generation (i.e. Rashida) who cherishes Indian culture and traditions. Despite apartheid, the Grey Street area became a new 'home' to them, filled with good (and bad) memories. On the other hand, there is a younger generation that is faced with a dilemma. Firstly, they (i.e. the children, Latif, Perumal, and his wife) experienced the apartheid regime only in part, if at all, and secondly, they are torn between the (old) traditions of Indian culture and an increasingly globalised and modern (new) South Africa. This necessarily leads to differing relations with regard to the apartheid past, which express themselves in two distinct forms of nostalgia, as argued above. 
The collection's opening thereby marks a distinct interplay of chaos and order. A first wave of chaos is triggered by the children's provocation and momentarily calms down with Perumal's unexpected appearance. The second wave of chaos is prompted by Anuradha's intervention in Rashida's unsubstantiable accusations towards her husband. It culminates in the two women's physical tangle and comes to a halt with Latif's return. The commotion rekindles in Rashida's flat when Latif tells his mother about his wedding plans and return to Johannesburg, but abates with Latif's ultimatum. The constant fluctuation between moments of chaos and moments of order is a discernible (rhythmical) pattern, not only in the opening vignette but throughout the whole collection, which becomes a distinct feature in the collection's portrayal of spatio-temporal arrangements in the Grey Street area. In each of the eleven vignettes, different unpredictable moments of chaos challenge the protagonists and destabilise the social interrelations and interactions of the character(s) in question. It is striking that the element of disorder permanently alters the power-generations in all but one story. ${ }^{22}$ Typically triggered by a clash of the older and the younger generation (in addition to the two generations' opposing views and expectations), the interplay of chaos and order thus, once again, mirrors nostalgia's fundamental past-present dichotomy. At the same time, its destabilising effect is a powerful reminder of "the surprise of nostalgic seizure" (Laubscher 215) in the form of the older generation's inability to control the younger generation and dictate their (joint) present based on the hopes and wishes fostered within the restrictive conditions of the apartheid past. The constant ups and downs thus ultimately speak to the neighbourhood's ongoing involvement with its turbulent past and its ramification into the new South Africa at a time when people seem to not yet (fully) have gained a foothold.

This social instability is echoed in the constant change of focus throughout the collection. I have briefly touched upon the topic above in connection to Fatima's 'walking tour' through the Grey Street area. Overall, there is a constant (vertical) oscillation between close-ups and long-shots. The opening story draws the (implied) reader into the world of the Grey Street area and has him/her symbolically enter the neighbourhood through Rashida's open front door. Once Latif closes the door later in the opening story, the (implied) reader

\footnotetext{
22 At the end of "Princess" (64-77), the domestic worker, after which the collection's sixth vignette is named, returns to her employer Zohra Bibi, and apologises. With her apology, the initial power relations (and thus the order) are restored. This outcome thus ironically reestablishes the historically rooted hierarchical dependence of Durban's Zulu population on Durban's Indian population.
} 
has become part of the Grey Street area. This zooming effect, both the zooming in and out, is also reflected on the narrative level. The collection predominantly exhibits an omniscient third person narrator, who orchestrates these shifts of focus. This choice suggests a general authorial distance between the narrator and the object of narration. Only two stories, i.e. "Home Sweet Home" (7885) and "Living with Dadima" (86-93), have a first-person narrator. Interestingly, these two stories follow the collection's centrepiece "Princess" (64-77).

"Home Sweet Home" is set in Verulam, a town about 30 kilometres north of Durban. The story follows its protagonist, a young girl, through her childhood memories of the summer of 1963 at her grandparents' house. One day the son of her grandparents' servant discovers a marijuana plant on the side of the road leading to the house. As the children admire the plant, they swear each other to secrecy, including their curious, youngest cousin Razia. It is the same summer that Auntie Fozie, the protagonist's youngest paternal aunt, is to be engaged to Dawood Moosa's son, no one less than the future heir of both Moosa's Supermarket and AK Mansions. All plans are thwarted, however, when Razia breaks the children's oath and asks Dawood Moosa if he has come to buy the marijuana.

While the story's first-person narrator exhibits a vertical approximation on the narrative near/far-axis, the vignette's setting has a twofold decentralising effect in the horizontal dimension. The setting not only spatially (re-)moves the story from the Grey Street area but also temporally, as the story takes place in 1963 and thus roughly four decades earlier than the remainder of the collection. The story's fond retrospective view furthermore rekindles the theme of nostalgia.

In "Living with Dadima" the vertical decentralising effect is resolved. Set in AK Mansions again, the vignette tells the story of twelve-year-old Rokaya, whose father runs a shop on the building's ground floor. Emotions run high when Rokaya's parents and paternal grandmother find out that Sumaya, Rokaya's older sister, is in love with Ifraan, the Pakistani who works at the father's shop. Before the father can confront Ifraan, however, the latter runs away and the love affair ends abruptly. This incident of xenophobia finds a continuation on the day Rokaya decides to bring home her black friend Pumi from school, only to see her grandmother chase her out of the living room, mistaking her for the domestic worker's daughter. This episode again reflects the historically rooted tensions between Durban's Indian and black population. 
Equivalent to "The Paki", "Living with Dadima" locates xenophobic tendencies within the older generation, i.e. the parents and above all the grandmother. The grandparent-grandchild relationship between Dadima and Sumaya is in any case portrayed as a particularly difficult one. Expected to become the next doctor in the family, Sumaya has different plans and wants to take a gap year before starting her studies. According to the grandmother, however, "[y]oung girls mustn't travel alone under any circumstances! [...] It's fine for boys but not for girls! If only you had a brother, you could have travelled with him to Europe" (87). Dadima's view is thus characterised by two unmistakably separated, gendered spaces with clear expectations for each gender. A point the grandmother does not miss to constantly remind her daughter-in-law of, for example, is that "an Indian mother is considered a successful one if she produced a son" (88). This (social) expectation is reflected in the collection's first vignette, "Latif's Mother", which similarly defines Rashida through her son.

Similarly gender-restrictive is the following discussion that arises in response to Firoz' wish to become a chef in "All about the Money" (103-113):

Uncle Moshin asked his nephew calmly, 'Firoz, what type of career is a chef? For a man too?'

His father's sister, Ruwaida, added, 'Everyone will look at you and laugh at you. You should look into engineering or law or accountancy. Look how well Yusuf is doing as an accountant. He earns so much money too.'

'But I am not interested in them. Besides the best chefs in the world are male. So why can't I become one? I have a passion for food.'

'One day you will get married and your wife will do the cooking. There will be no need for you to cook. Cooking is for females only,' Auntie Ruwaida said as she nodded her head emphatically. (106)

Both examples demarcate the South African Indian community as distinctly patriarchal. There are clear (restoratively nostalgic) expectations of women, who, in view of their restricted mobility, their responsibility to bear a son, and their cooking duties, are confined to the domestic sphere. Firoz, whose career aspirations blend the (female) domestic and (male) public sphere, does not meet his family's (restoratively nostalgic) expectations as to what constitutes a suitable career choice for a man. The primary duty of men, as the story's title suggests, is to have a well-paid job. This is humorously underlined by the father's sudden approval of Firoz' career choice after reading an article on Jamie Oliver and the "fact that he was a self-made millionaire" (113), which also em- 
phasises how much easier it seems to be for Indian men to transgress cultural boundaries.

These gender and age restrictions, which both Firoz and Sumaya face, reflect what Tarry Frankish and Jill Bradbury call "the (im)possibility presented to young people to navigate their own lives" as an older generation "navigate[s] and negotiate[s] lives in the present and the future out of the remnants of the past" (305). While it should be noted that this form of (im)possibility differs from the younger generation's increasing (in)ability to (fully) remember the apartheid past due to their young age, the two are nevertheless closely linked. The form of (im)possibility that Frankish and Bradbury describe, in fact, poses yet another structural hindrance that the younger generation has to compete against.

Interestingly, the gender aspect is undermined by age and its social 'ranking function'. This becomes evident by the peculiar power the paternal grandmother seems to have over the family:

[Dadima] lived with us and thought she had a say in the running of our lives, which she did to a certain extent because Papa would not hear of anyone saying anything against his mother's wishes.

Mummy would get caught up occasionally in this feud but she never took anyone's side. (Akabor, Flat 9 88)

Dadima's age, which affords her a venerated position within the family and consequently bestows her with a strange power over the younger members of her son's family, places her at the head of the generational hierarchy. While Sumaya's constant challenging of her grandmother's views can be read as an attempt to break away from these 'traditional' familial structures, she ultimately fails to reach her goal as both her relationship with Ifraan and her wish to travel to Europe remain unfulfilled.

In contrast to Sumaya, Fatima's brother Salim succeeds in overcoming a similar familial tradition. As the family's only son, it is Salim's "duty to look after his mother, even if his wife disagreed" (32). By shunting his mother off to Durban, however, Salim not only honours his wife's wishes (who does seem to disagree with the previous arrangement (33), probably because of her motherin-law's difficult illness), but also turns Fatima's life upside down. This counter example reveals how the younger generation of South African Indians endeavours to break free from certain seemingly outdated traditions, but reinforces gender inequalities. 
Another prominent example of such a restrictive gendered space can be found in "Flat 9", the collection's title story (45-49). Every Friday afternoon Hawa Khala, Mrs Bhoola, and Najma meet at Zohra Bibi's place, flat 9 on the second floor of AK Mansions, for tea (35). One day, Najma, the group's youngest member, unexpectedly leaves to look after her mother who has fallen ill. The remaining three women meet for tea the following Friday where Zohra Bibi updates her friends about the second marriage of Najma's husband, the real reason behind their friend's sudden departure. In reaction to the news, the following heated debate ensues:

Mrs Bhoola's face contorted with anger. 'How can you be so normal when Najma is going through all this?'

'What can we do? Goolam is already married to his second wife!' Zohra Bibi said.

'As a Muslim, he has committed no sin,' Hawa Khala added. After pausing a moment to bite into her muffin, she continued, 'My nana had three wives. But he only married the second and third ones after his first had passed away.'

'I think that this practice makes no sense and only serves to demean women,' Mrs Bhoola said in irritation.

Zohra Bibi was quick to reply, 'Would you rather have men living in sin with other women or living respectably?'

'It's not about living respectably... it's the whole concept of having the option to be with more than one woman, I suppose.'

Hawa Khala intervened, 'Mrs Bhoola, you don't understand the reasoning behind polygamy.'

Mrs Bhoola sighed. 'Well I really don't think there can be any rational explanation for such a custom!'

'The same can be said for the Hindu practice of suttee. Why does a woman have to burn herself when her husband dies? Why are widows treated so badly in your religion? Can a woman help it if her husband dies before her?' Zohra Bibi asked, but didn't wait for her Mrs Bhoola to reply, 'I think that suttee is actually worse than polygamy.'

'Suttee is not demeaning! Polygamy is! Suttee shows a woman's loyalty and virtuosity!' (43-44)

The three women's discussion displays a strong bond of 'female solidarity' and what is a religious debate at heart culminates in a crosstalk between Zohra Bibi and Mrs Bhoola with the latter's defeat and sudden departure. It is striking that this act of solidarity takes places in a private space of seclusion with no men present and ultimately no concrete impact on the problem at hand. 
Najma is not able to escape the religious custom and her husband's decision, but returns to him and accepts her fate. It is a noticeable detail that Najma's acceptance is never discussed by the group of friends but finds expression in Najma baking her "special date and nut cake" (48) for their first reunion after Najma's return to AK Mansions. This finesse - that picks up the idea of food and its unifying function, and I would add friendship and solidarity in this particular case - speaks for the collection's sensitivity in dealing with and subliminally critiquing delicate socio-cultural issues. The feeling of 'home' acquires an important acoustic dimension by the sounding of the (familiar) azaan that ends the women's get-together (49). The azaan's circularity and regularity furthermore parallels the women's tea ritual. Nevertheless, the story leaves the (implied) reader with a stale aftertaste as it ends with the women discussing a current murder case and gossiping their way through the afternoon in their customary way, moving on to business as usual as if Najma's problem had never existed.

Overall, the generational conflicts at hand in Akabor's short story collection seem to feature two characteristics: While the generational conflicts show a balanced picture (both the older and the younger generations are victorious throughout the collection), the female characters, particularly the ones from the younger generation, seem to be marked by a double, if not triple, marginalisation brought about by: (1) Indian culture, (2) their gender, and (3) their age. These three markers seem to make women of the younger generation particularly likely to lose a generational conflict, such as in Fatima's or Sumaya's case. I would argue that the collection's reflectively nostalgic (re-)creation of the Grey Street area (as a lieu de mémoire) consciously shifts the focus to the needs of the younger generation among South Africa's Indian community. While the former Grey Street is a distinctly memorable place for the older generation, it becomes an increasingly immemorable place for the younger generation who "wishes to move away from an inner city that no longer signifies 'Indianness'" (Govinden, "Healing" 295). ${ }^{23}$ In addition to the impossibility to remember the Grey Street area's apartheid past due to their young age, the

\footnotetext{
${ }^{23}$ In a personal interview, Mariam Akabor confirmed this tendency. In addition to the growing number of foreigners, which increasingly prompts the remaining Indian families to leave the neighbourhood, Akabor thinks that the Grey Street area "looks dirtier" and has become "more dangerous". In combination, these elements lead to the neighbourhood's increasingly less residential flair. Akabor furthermore said that now that her husband's uncle has sold the house in which she and her husband used to live and consequently her last relatives are moving out of Grey Street, she sees no more reason to go back to her former home-place (Akabor, Personal Interview).
} 
younger generation is also faced with a varying (im)possibility to determine their own lives. This is due to the fact that the younger generation's freedom of choice is restricted by both the older generation's high hopes, which are based on their own reflective apartheid nostalgia, as well as the predominant cultural constraints. Flat 9 thus illustrates how the younger generation is caught in a past which is only partly theirs, a past which keeps chasing them and keeps obstructing their future. Reflective nostalgia, ultimately, becomes a distinct form of critique in Akabor's short story collection and the various socio-cultural problems that the younger generation faces leaves the (implied) reader with the question "whether we can talk about a 'born-free generation'" (Frankish and Bradbury 305) or whether it is too early as of yet. 


\subsection{ROZENA MAART'S ROSA'S DISTRICT SIX}

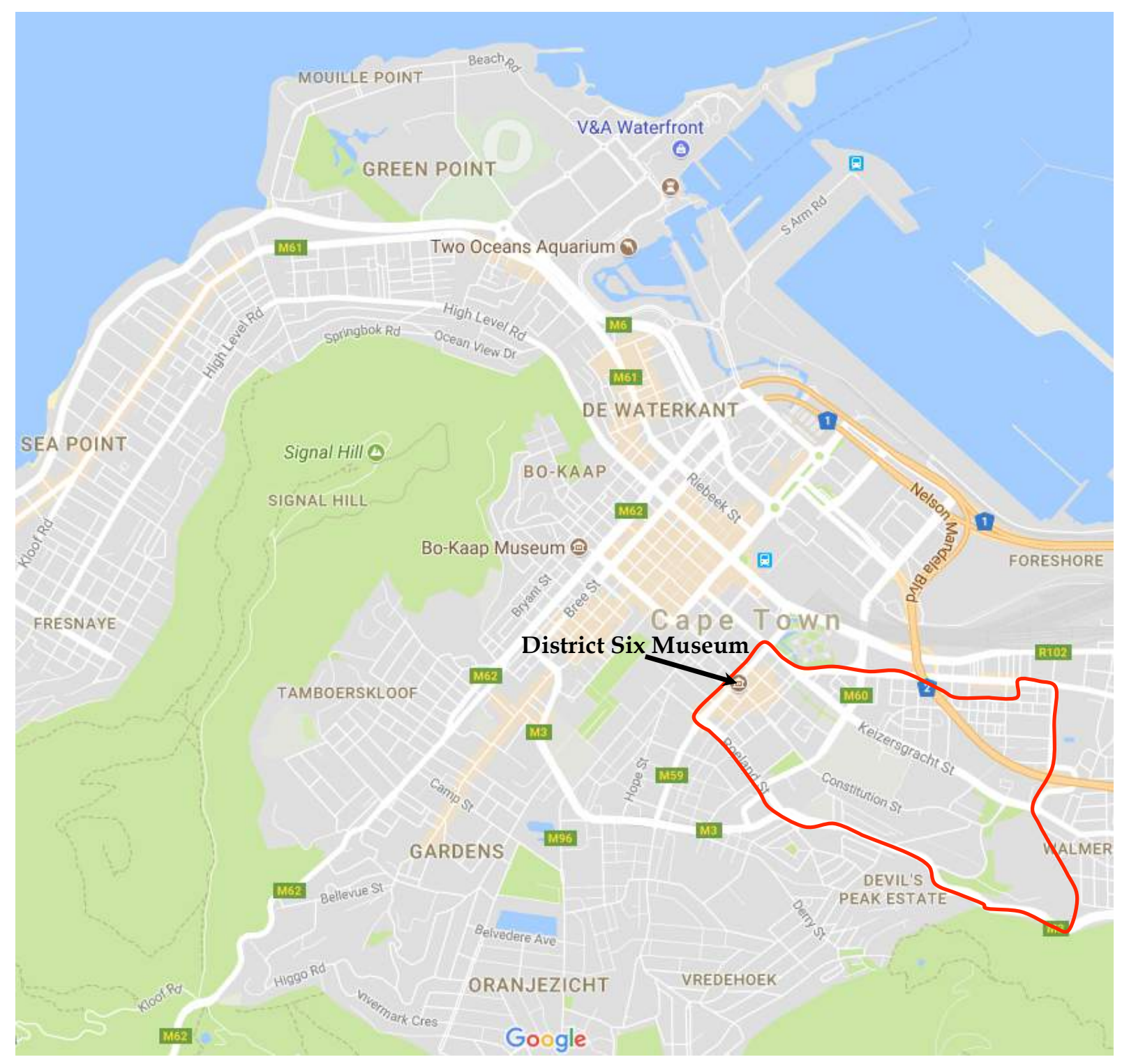

Figure 4: Map of District Six, now Zonnebloem.

The neighbourhood of District Six - situated in Cape Town's city bowl at the foot of the Devil's Peak mountain, on landscape with a slight downward gradient - spans the area from Roeland Street and De Waal Drive in the south to Sir Lowry Road in the north and from Buitenkant Street in the west to Searle Street and Cambridge Street in the east (see Figure 4). Initially known as Kanaladrop by locals - derived either from the fact that several canals had to be crossed in order to reach it or from the Malay word kanala, "a reciprocal pooling of talents and tasks, and an indication of the spirit of community it came to symbolize" (Hart 119) - the neighbourhood was renamed with the Municipal 
Act of 1867 which saw the reorganisation of Cape Town's municipality into six districts (Bickford-Smith, "The Origins" 36; Hart 119; Manuel and Hatfield 1).

The origins of District Six go back to the turn of the nineteenth century, when the first houses were built in the area to accommodate officers who were stationed at the neighbouring Castle of Good Hope; over the next five decades the neighbourhood became home to 3,000 people (Hart 119). By the end of the nineteenth century, District Six was "a sizeable residential area with a cosmopolitan population of approximately 30,000" (Bickford-Smith, "The Origins" 36), a development that also has to be seen in view of the emancipation of the slaves in 1838 (Hart 119). While the District's population in the mid-nineteenth century was composed of a mix of all of Cape Town's social classes, the city's social stratification became more clear-cut with the emergence of railways and tramways in the second half of the century. This resulted in the richer population settling west of the Castle in the Gardens, as well as in the city's southern suburbs, Green Point, and Sea Point (Bickford-Smith, "The Origins" 37; Hart 119). Economically, the District's population at the turn of the century was thus working-class and consisted of a mix of artisans, dockworkers, merchants, shopkeepers, "with a tiny sprinkling of professionals in the form on an occasional doctor, clergyman or lawyer" (Bickford-Smith, "The Origins" 37). Culturally, the population was predominantly of 'mixed' race: generally categorised as 'Malays', who were descendants of former slaves brought to South Africa by the Dutch East India Company in the seventeenth century, and 'Coloureds', descendants of 'mixed' marriages between Khoi, other Africans of Bantu origin, or between 'Malays' and white settlers. However, the District was also home to people from several African tribes from the Eastern Cape, Indians, Jews (usually Russian, German, and Polish), Chinese, Brits, and Australians (Bickford-Smith, "The Origins" 37; Hart 119-120). It was the neighbourhood's proximity to Cape Town's CBD and the city's economically thriving docklands as well as its vibrancy that attracted both local and foreign migrants alike.

The notorious reputation of District Six as "a ripe, raw and rotten slum" that "was drab, dingy, squalid and overcrowded", to quote the author Richard Rive who grew up in District Six ("District Six" 111), came almost concurrently with its official (re-)naming in 1867 (Hart 120). The neighbourhood's bad reputation can be attributed to "the severe neglect of District Six" by the municipality of Cape Town (Bickford-Smith, "The Origins" 39) which, for instance, failed to provide sufficient wastewater facilities or to adequately deal with the rapid population growth that, in turn, supported the inflated rental rates (Hart 
120). At the same time, the neighbourhood's poor sanitary installations and its overpopulation made it susceptible to epidemics such as the smallpox epidemic in 1882 (Bickford-Smith, "The Origins" 39) or the outbreak of the bubonic plague in 1901 (Bickford-Smith, "The Origins" 40; Hart 120). Both outbreaks hit the District hard.

It is against the socio-historical background of the nineteenth century that the city's 'slum clearance' scheme in the first half of the twentieth century has to be understood (Bickford-Smith et al. 146). The Slums Act of 1934, which gave both the municipalities and the government the power to acquire dilapidated buildings for demolition and rebuilding, brought the necessary legislative amendments to effectuate the vision of a 'clean(er)' Cape Town. The impact of the act was twofold: It not only encouraged landlords to upgrade their properties, but it also allowed the city officials to formally determine particular neighbourhoods, such as District Six, as 'problematic' (147). While World War II put the slum clearance scheme to a halt (Manuel and Hatfield v), the victory of the Nationalist Party in the 1948 elections marked the beginning of a whole series of new legal measures to further the separation of the country's white from its non-white population. Most prominent amongst these measures is the Group Areas Act of 1950, which provided the legal basis for the population's allocation to different residential areas and business locations according to their race (Bickford-Smith et al. 159). It was, however, not until 11 February 1966 that District Six was declared a White Group Area (BickfordSmith et al. 154; Hart 125). Subsequently, between 1968 and 1982 (BickfordSmith et al. 183), more than 60,000 people were forcibly removed from District Six to the Cape Flats some twenty-five kilometres away from Cape Town's city centre and all but a number of religious buildings, such as the St. Marks Anglican Church (see Figure 5), were bulldozed (154).

In the aftermath of its destruction, the significance of District Six as one of the country's multicultural strongholds grew exponentially and resulted in its symbolisation as the archetypal space of black and coloured suffering under apartheid oppression. In contrast to Sophiatown in Johannesburg or Cato Manor in Durban, for example, "District Six had the advantage of remaining a visible scar on the slopes of Devil's Peak, an open wound not immediately patched over, that became a constant reminder of the callousness of the apartheid regime" (M. Murray, Commemorating 115). The reason for this is the continuous opposition both from inside and outside of District Six, first to the 
forced removals in the late 60s and throughout most of the 70s and later to the neighbourhood's redevelopment from the late 70s onwards. ${ }^{24}$

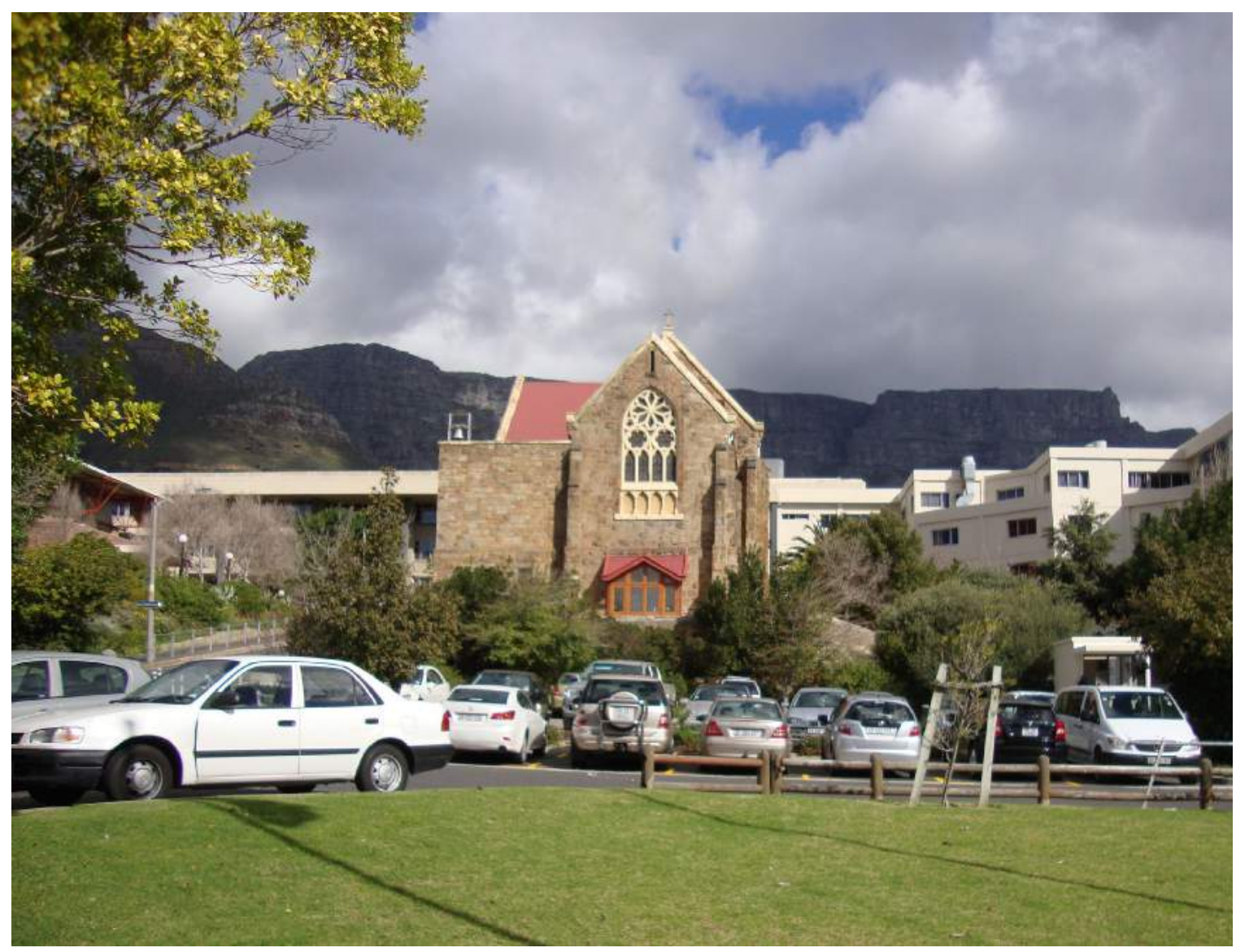

Figure 5: St. Mark's Anglican Church in Zonnebloem.

Considering the neighbourhood's symbolic significance, it is not surprising that the long and tumultuous history of District Six and the wish to keep memories of the area and its vibrancy alive found multimedial expression. ${ }^{25}$ The District Six Museum, which is located in the former Central Methodist Mission in Buitenkant Street and opened in December 1994 (District Six Museum), is doubtlessly "the prime site of District Six remembrance" (Erll 35). The District Six Museum Foundation, which originated from the Hands of District Six campaign - responsible for successfully preventing the redevelopment of the neighbourhood by the oil giant BP in 1986, for example (Soudien 171-177) - inextricably links the museum to the (continuous) struggle for District Six mentioned above (see Jeppie and Soudien). Since its opening, the numerous exhibitions and its rich (archival) collections have made the museum a key in-

24 For an overview, see Soudien.

25 For an overview, see Erll 35-37; McCormick 202-206; Rive “District Six". 
terface for both a local and international public as well as researchers on the subject. ${ }^{26}$ The history of District Six has been documented in painting, photography, music, film, as well as personal memoirs and fictional texts. As a detailed overview would go beyond the scope of this study, ${ }^{27}$ I present a brief account of the fictional representations of District Six, below.

Writers such as James Mathews, Adam Small, Dollar Brand (more famously known as Abdullah Ibrahim), or Graham Ellis have written poetry on District Six. The first novel to be partly set in District Six, according to Richard Rive ("District Six" 114), was Peter Abrahams' The Path of Thunder. The most famous fictional representations of the District, however, are doubtlessly Alex La Guma's novella A Walk in the Night, Achmat Dangor's novella Waiting for Leila, and Richard Rive's (by now cult) novel 'Buckingham Palace', District Six. Rive's novel was later adapted into a play by Rive himself. He was, however, never to see the production at Cape Town's Baxter Theatre, as he was murdered a fortnight before the play's opening night on 4 June 1989.28 Basil Appollis, who portrayed the narrator Richard in the novel's theatre adaptation, reworked Rive's novel in "My Word! Redesigning Buckingham Palace", a oneman show celebrating the live and work of Richard Rive, as well as the District's vibrant history that premiered at the Baxter Theatre on 26 November 2013 (Saunders). Besides Rozena Maart's Rosa's District Six, Carol Ann Davids' The Blacks of Cape Town and Nadia Davids' An Imperfect Blessing, two recent novels that are both partly set in District Six, should be mentioned. These recent works are proof of the ongoing contemporaneity and enduring significance of the neighbourhood and its history.

\footnotetext{
${ }^{26}$ For the history of the creation and curation of the museum, see Rassool and Prosalendis.

27 On paintings of District Six see e.g. Maurice; on photography see e.g. Greshoff as well as Hallett and McKenzie; for a general overview of the photographic documentation of District Six see Smith and Rassool; on Cape Jazz see e.g. C. Miller or C. Muller; on David Kramer's and Taliep Petersen's District Six - The Musical and Kat and the Kings see e.g. Jaffer or de Villiers and Slabbert. With regard to films on District Six see e.g. Rive ("District Six" 112) who mentions Lindy Wilson's Last Supper at Hortsley Street, a 1983 short film that portrays a family's forced removal, and Yunus Ahmed's Dear Grandfather, Your Right Foot Is Missing, a postdestruction documentary from 1984. More recently, Neill Blomkamp's internationally acclaimed science fiction film District 9, whose title and premise are inspired by District Six and its history, has to be mentioned (see e.g. Erll for a discussion of the film in connection to District Six). There is also a considerable number of memoirs, documenting both the familial and communal life of former residents, such as The House in Tyne Street: Childhood Memories of District Six by Linda Fortune (for a more extensive list of memoirs see McCormick 203-204). 28 On the novel's adaptation, see Viljoen's book, Richard Rive: A Partial Biography.
} 


\section{APARTHEID NOSTALgIA IN ROSA'S DISTRICT SIX}

Rozena Maart (b. 1962) was born and raised in District Six and in 1973 Maart and her family were forcibly removed. She later studied Literature, Philosophy, and Psychoanalysis. While she did her undergraduate studies at the University of the Western Cape, Maart holds an MA from the University of York. She then obtained a PhD from the University of Birmingham. Maart taught at various universities in England, Canada, and the United States before returning to South Africa where she is currently director of the Centre for Critical Research on Race and Identity (CCRRI) at the University of KwaZulu-Natal in Durban. Besides her many academic contributions, Maart is also the author of several works of fiction: the collection of poems Talk About It!, the short story collection Rosa's District Six, and the novel The Writing Circle. In 1992, her short story "No Rosa, No District Six" won the Canadian Journey Prize and later became the opening story of Rosa's District Six. The Writing Circle was shortlisted for the 2010 Aidoo-Snyder Book Prize (Maart, Personal Interview; Rozena Maart).

Set in Cape Town's District Six in the months of April and May 1970, Ro$s a^{\prime} s$ District Six circles around the daily lives of a number of District Sixers at a time when the apartheid laws had reached their full scope and the relocation of the neighbourhood's residents had already started. The collection's five short stories share one commonality: little Rosa, the collection's central character, whose explorations guide the (implied) reader through the neighbourhood and weave together its inhabitants and their (hi)stories.

Maart's short story collection thus forms part of the rich, ongoing tradition of recollecting District Six and the lives of its residents. In the collection, the restriction of the time frame to the months of April and May 1970 speaks to apartheid nostalgia as the predetermined form of (be)longing to/for the place. However, the fact that District Six does not physically exist anymore, an obvious difference in comparison to Durban's Grey Street area, necessarily triggers different aspects of apartheid nostalgia which, as I will show, are linked to aspects of pain and suffering. The impossibility of a physical return to the former (home-)place inhibits a physical comparison of past and present. This embeds the nostalgic act (even) more firmly in the realm of thought, making it "fantasmatic", to use Hook's term (182). 
While the literary works of the so-called 'District Six Writers', i.e. Richard Rive, Alex La Guma, and James Matthews, ${ }^{29}$ have received considerable academic attention, ${ }^{30}$ few academics have worked on Maart's collection. The scholarly interest in Rosa's District Six up to date has thereby predominantly focused on the same-sex relationships as portrayed in the collection's opening and closing stories "No Rosa, No District Six" (1-14) and "The Bracelet" (163225), respectively. Jessica Murray reads the lesbian relationship in "No Rosa, No District Six" as a form of social defiance against "an environment that is characterized by extreme racial and gender oppression" (60), but also wishes to raise awareness of the apparent lack of engagement with lesbianism in South African literary criticism (52-53). Brenna M. Munro, in connection with what she calls "Richard Rive's queer nostalgia" (105), sees Maart's collection as "a female counterpoint to Rive's work" (136). She argues that while "[c]oming out as queer is [...] combined with coming out as coloured" (138) in "The Bracelet", the lesbian relationship in "No Rosa, No District Six" can be seen as "a sign for women's hidden power in the culture of District Six" (140). Jean-Paul Rocchi regards the two stories as "a breach with the black masculinist nationalism of the new South Africa and with the mythification of the postcolonial moment as a radical break in which only demonstrably heterosexual South African men would be counted" ("Literature" 63). Elsewhere, he argues that "No Rosa, No District Six" is an expression of a triple displacement "deployed on spatio-temporal, historiographical and feminine textual terrains" and a critique of "the dismemberment and the partition of the national consciousness along ethno-racial, sexual, and gender lines" ("Intersecting" 375, 381). ${ }^{31}$ Influenced by the feature of Cloete Breytenbach's photograph "Seven Steps" on its cover (Breytenbach and Barrow 30), ${ }^{32}$ Astrid Erll sees Maart's short story collection as taking part in a by now established tradition of

\footnotetext{
29 On these writers see e.g. R. Gaylard 133-178.

30 This is particularly true for Alex La Guma's and Richard Rive's works that remain of considerable scholarly interest to this day. On La Guma see e.g. Diala-Ogamba; Field; van der Vlies; or López. On Rive see e.g. Viljoen, "Langston Hughes", "Non-Racialism", "Richard Rive", and Richard Rive; G. Davis; Farred; or Munro.

31 This chapter is a shortened translation from the earlier, French version, "Walls as Words as Weapons as Womb as 'Woooooow'; Fente murale, fente $t / \operatorname{sex}(u)$ [elle], fondu identitaire: Jouir/écrire ou la post-identité dans 'No Rosa, No District Six' de Rozena Maart".

32 Other books that display one of Breytenbach's pictures on their cover are the 2006 edition of Alex La Guma's A Walk in the Night by Trent Editions or the 2006 edition of Richard Rive's 'Buckingham Palace', District Six by Cornelsen Senior English Library (Erll 40). Consequently, Erll argues that "[i]t seems as if Breytenbach's photographic collection [The Spirit of District Six] has become a nodal point in the plurimedial constellation constituting 'District Six' as a memory schema" (40).
} 
"mnemonic cross-referencing" in the context of District Six and its history and argues that such practice has been part of establishing the neighbourhood "as a shorthand for lost hybridity and creole reality burgeoning in a multicultural urban space" $(39,45)$.

In view of the predominant interest by the above-mentioned scholars in the way in which the two stories (re-)negotiate the neighbourhood's historicity, i.e. "the quality of a discourse [...] or even of an opinion" (Harré and Moghaddam 95), it is astonishing that the merit for an analysis of the entire collection, and not just those two stories, has remained unnoticed. Erll's discussion of District Six in the context of so-called 'memory schemata', ${ }^{33}$ and Munro's loose placing of Maart's collection within a broader framework of post-destruction and post-apartheid nostalgia certainly suggest the warrant for such an approach.

In what follows I argue that in Maart's short story collection, similar to Akabor's, reflective nostalgia is used as a means to critically (re-)negotiate District Six and its history. In contrast to Flat 9, which places the focus on Grey Street's younger generation and its conflicts in connection to a changing/changed place, I illustrate the foregrounding of an older generation and its reminiscences of a (lost) place in Rosa's District Six. The short stories thereby demonstrate a distinct interplay between 'the ordinary' and 'the spectacular' (Ndebele), which, however, strives to highlight the former (rather than the latter) as a means to (re-)conquer District Six and its everyday stories, with little Rosa as golden thread. It is, in fact, through Rosa's character and her unclearly defined physical condition that aspects of documentability and historicity of the District's past are addressed and (re-)negotiated.

The collection's retrospective gaze, even if somewhat covertly, is presented in the opening lines of "No Rosa, No District Six":

mummy and mamma orways say dat I make tings up and dat I have a lively emagination and dat I'm like der people in der olden days dat jus used to tell stories about udder people before dem das why mummy and mamma orways tear my papers up and trow it away but tis not tru I never make tings up I orways tell mamma what happened and mamma doan believe me and I tell mummy and mummy doan believe me too and den I write it on a piece of paper or on der wall or behind Ospavat building or in der sand at der park and Mr Franks at school he doan believe me too cos he says dat I orways make

\footnotetext{
33 Erll defines 'memory schemata' as "patterns and structures of knowledge on the basis of which we make assumptions regarding specific objects, people, situations and the relation between" (31).
} 
trouble wi der teachers and I talk too much and I jump too much and I laugh too much and I doan sit still too much and I orways have bubble gum and I orways have pieces of tings and papers and my hair orways comes loose and mamma toal Mr Franks dat I'm under der doctor and dat I get pills cos I'm hyper active like mamma say 'someone who is restless all der time' but Mr Franks doan believe dat I'm under der doctor cos I make too much movements [...] (Rosa's District Six 1)

The story sees eight-year-old Rosa skip school and hide in Mrs Hood's and Uncle Tuckie's house. When Mrs Hood and Auntie Flowers, whom Rosa expects to go grocery shopping, unexpectedly re-enter the house, Rosa hides under the bed and becomes witness to an erotic encounter between the two women everyone believes to be cousins.

Rosa's description by her "mummy and mamma", i.e. her mother and grandmother, as someone who is "like der people in der olden days dat jus used to tell stories about udder people before dem" places her along a transgenerational tradition of remembrance connected to District Six and its history. The child narrator's loquacity, on the one hand, suggests that storytelling seems to be something that comes naturally to Rosa and lends her innocence and likeability to her account, while her disregard for punctuation and standard spelling, on the other hand, further bespeak Rosa's essential joie de vivre and simultaneously imply Rosa's impatience and unruliness. It seems as if Rosa's impetuosity and lack of self-control sweep across any regard for linguistic 'correctness'. This contradiction in Rosa's character embodies the multicultural and at times contrastive character of the lives and people in District Six, presented in Rosa's District Six as objecting to the apartheid ideology. In that respect, the collection contributes to the District's well- and over-established memory schema as the stronghold of black and coloured culture and the archetypal space of black and coloured suffering under the apartheid regime. While such an (over-)simplification, and this is in addition to "migrants and mass media as their carriers" (Erll 32), may, to a certain extent, be helpful and even necessary for memory schemata to 'travel' and reach transnational and transcultural status, it disregards more (self-)critical facets of memory such as they are present in Maart's collection. Memory schemata, at least as presented by Erll in the context of District Six, do not seem to account for the connection between memory and nostalgia, but obtain a one-sided, restorative character instead. The more (self-)critical, or rather reflective, side of remembering District Six, however, is ostensible from the outset of Maart's collection. 
The reflectiveness of the collection is inextricably linked to questions of secrecy, reliability, and legitimation. Munro pointedly argues that " $[t]$ he image of papers being torn up and thrown away and the idea of stories that are disbelieved by figures of authority" in the above quoted excerpt "evoke all kinds of lost or forbidden histories" (139). The connection between underrepresented histories and aspects of secrecy becomes particularly apparent in the following passage in which Rosa relates a recent history lesson about Jan van Riebeeck and the founding of the Cape Colony:

[...] and four weeks ago Mr Henson teached us Van Riebeeck made Cape Town and built a fort and erecticated a half way station for food and supplies for der Dutch people and der European people [...] and den Mr Henson also toal us dat Van Riebeeck's wife Maria de la Quelerie [...] den Mari der big girl in my class she has der periods oready she toal us she wondered where Maria put her cotton clot wi blood on it in der ship from Holland cos Mari's mummy told her not to tell her daddy her broder or her uncles about her periods cos men mus never see or know dees tings and den we all laughed cos Mari's very funny and today we had to give in our assignments on Van Riebeeck and Mr Henson ga me four cuts on my hand cos I drew a picture of Maria and not Jan and $\mathrm{Mr}$ Henson say dat der assignment was about Van Riebeeck and not Maria and I say is der same ting cos it was part of der same history lesson and Mr Henson screamed at me to shut up [...] (Rosa's District Six 1-2)

The incident has rightly been read as a spatio-temporal entanglement of Rosa's fictional(ised) present and an andro- and Eurocentric historiography with Rosa's decision to draw Maria rather than Jan as a re-writing of history with an intuitively feminist inscription (J. Murray 56-57; Munro 138-139; Rocchi, "Intersecting" 374-375). Rosa's captivation with female menstruation is pivotal in this historical (re-)negotiation: It is not only "the point of the overlapping of individual and collective history, spheres of the past and the present, the creative imagination and historiographical determinism" (Rocchi, "Intersecting" 374) or evidence as to "how girls become socialized into shame" (J. Murray 56), but it also pre-empts Rosa's (re-)considerations with regard to her notion of 'secrecy'.

After the passionate love making between Mrs Hood and Auntie Flowers, Rosa remains behind in Mrs Hood's bedroom processing what she has witnessed. Once her initial fit of laughter subsides, Rosa comes to the decision that "[i]t's a secret and nobody knows" (Maart, Rosa's District Six 13). As if to lend it more gravitas, Rosa performs a little ritual to seal her decision: 
She raised herself almost graciously, in adult fashion, and found a piece of wood at the back of the yard and took a splint from the dry log. Having pricked her finger, as she usually did when writing on walls and implanting her print, she swore to secrecy and vowed never to talk about the events she had witnessed. (13)

This ritual act symbolises Rosa's initiation to the world of (female) adulthood and its (need for) secrets and contradictions, as Rosa remembers her grandmother's directive to "talk about everything, hide nothing" followed by the restriction that "when you grow older, you'll find out that there are some things you jus doan talk about. These things take time to talk about" (13). At the same time, Rosa's ritual also initiates the (implied) reader to the multicultural, animated, and - in view of the grandmother's instructions - contradictory world of District Six and implicitly includes him/her in the obligation to maintain confidentiality. Once the pact between Rosa and the (implied) reader is made, she "climbed over the wall and rested herself among the wooden logs of Mrs Benjamin's backyard. There was nobody home and she could climb all the walls to the end of the street" (14). Together with Rosa, the (implied) reader climbs over the wall and enters "the space of the 'after-wall'" (Rocchi, "Intersecting" 379) where Rosa disappears as the main focaliser but keeps reappearing throughout the remainder of the collection.

The uncovering, keeping, and - at least later on in the collection - breaking of secrets are closely connected to the question of narrative credibility and aspects of legitimation. Rosa's "lively emagination" and her being "hyper active" (Maart, Rosa's District Six 1) establish her as an unreliable narrator. This undermining of Rosa's reliability puts the erotic encounter between Mrs Hood and Auntie Flowers into question and makes it appear as childish imaginings and exaggerations. Rosa, who remains the focaliser once the narrative changes to third person and Standard English, does not seem to fully comprehend what is happening between the two women as her following reflection suggests:

Auntie Flowers stroked Mrs Hood's hair and made rings with it, sprinkling water on the curly strands. Some of the droplets nestled onto Mrs Hood's lips. The two women placed their fingers in each other's mouth. Rosa found it exciting to see grown women exchange spit. She wondered whether they did the same with food. Although this was an exchange of water, Rosa thought of it as equally defiant. Mamma Zila had warned Rosa so many times about exchanging 
food already chewed and Rosa thought about telling Mamma Zila about this incident. (10)

It is far more the exchange of spit that attracts little Rosa's attention than the two women's love act. Rosa's intention to tell on the two women based on her grandmother's warning "about exchanging food already chewed" further attests to her incomprehension, at least to some extent. Shortly thereafter Rosa also wonders: "Is this like sex? she asked herself, having been told that that was when a woman allowed a man into her vagina" (11). Even though Rosa seems to recognise the sexual nature of the encounter, her understanding of sex is abstract at best. This partial insight is underlined by Rosa's "odd angle from under the bed" (Munro 139), which lends her (narrative) position an additional (e)strange(d) character. This aspect of estrangement, in turn, mirrors the dis-placement that both the forced removals of the District's residents as well as the retrospective look on District Six as a lost place imply. Ultimately, the (implied) reader is left puzzled by the related events and Rosa's suggested unreliability is maintained beyond the collection's opening story.

The question of Rosa's (un)reliability is also linked to the (un)reliability of memories more generally - i.e. issues of incompleteness, fragmentation, and the subjective nature of memory processes - and, by implication, nostalgia more specifically. Certain elements of the past are (necessarily) altered and/or silenced, particularly if the past is marked by a traumatic event (Frankish and Bradbury 299-300). The forced removals under the apartheid regime are one example of such a traumatic experience which, consequently, connects apartheid memories and nostalgia to aspects of trauma. According to Stephen Legg, trauma and nostalgia:

are theoretically and practically linked. While nostalgia denotes a positive attachment to a past real or imaginary home, trauma denotes the negative inability to deal effectively with a past event. While both conditions represent a problematic engagement with the past, nostalgia often focuses on a time and place before or beyond a traumatic incident. (103)

The timeframe of Maart's short story collection - the stories are set in April and May 1970, shortly before the forced removals from District Six - thus follows the (typical) (dis)placement of nostalgic memories to a "pretrauma, although not preapartheid" past (Frankish and Bradbury 300). While the collection's spatio-temporal return is indeed concerned with the processing of the 
traumatic past, as I show below, it is reflected in Rosa's constant reappearance (or return) throughout the collection and the question of her (un)reliability.

The question of Rosa's unreliability is taken up by the collection's second story, "The Green Chair" (Maart, Rosa's District Six 15-61). The story follows the two sisters, Jasmin and Latiefa, who, left behind to clean the house while their mother and grandmother go shopping, are visited by little Rosa. After singing and dancing with Rosa, the two sisters fulfil their household chores and decide, against Rosa's intervention and unaware of the anger they would cause, to have their mother's favourite chair fixed.

It is with Rosa's warning as to why the two sisters should reconsider their decision that the issue of her supposed unreliability resurfaces:

'Auntie Magda talk to someone wit a boy's name in dat chair,' Rosa said.

'What?' Latiefa asked, as she frowned and looked at her sister.

'Is true. I was playing in der yard over there [...] and den I hear Auntie Magda speak to someone wit a boy's name and Auntie Magda talk to him and say tings.'

$[\ldots]$

'Argh! Rosa, remember what we said about making up stories?' Latiefa said again.

'Ja. I know,' the child replied.

'Well, so don't then. Go and call Uncle Peter, kanala, Rosa. We need to know what time he's leaving for Hanover Street.' Latiefa took another glance at her watch as the Town Hall clock struck one.

'Remember what happened with Faiz der other time... and you also said I was making up stories.'

'Mmmm, ja, that is true,' Latiefa said as she shook her head.

'Der policeman took him in der van...'

'Rosa, I don't want to hear about it anymore,' she interrupted. (29)

While Rosa's ghost story seems to corroborate her "lively emagination" (1) and her unreliability, the incident with the police that Rosa hints at in conversation with Latiefa is an indication to the contrary. The story's ending, which brings to light the mother's long kept secret about the death of her firstborn son to whose ghost she speaks every night, sees Rosa's reliability (re-)established and corroborated by Latiefa's acknowledgement that " $[\mathrm{t}]$ he young child was telling the truth" (60).

Through this ghostly apparition, the collection's nostalgic character also overlaps with elements of the uncanny. In this regard, Klopper argues that: 
Nostalgia is located in interesting ways not only between the psychic and the geopolitical but also between a determinate conceptual phenomenon and an indeterminate conceptual relation. It is useful, therefore, to think of nostalgia as located between the phantasy and the real. Thought of in this way [...] nostalgia begins to resemble the aesthetic figure of the uncanny. (148)

Klopper's remarks remind of the "fantasmatic" aspect of nostalgia that similarly places the concept in the realm of the imaginary (Hook 182). Laubscher's comment that "nostalgia is less like an elephant, and more like a ghost, less given to the empirical sense than the affective sensibility" which, rather than an ontology, consequently asks "for a spectral academics, and a(n) hauntology" (216) follows the same line of argument. Klopper continues:

The rhetorical relation between restoration and reflection [...] can be seen as an uncanny relation, a relation of splitting and doubling. Inasmuch as the one is the negative of the other, it is a relation of haunting, an encounter with the unfamiliar in the familiar and the familiar in the unfamiliar. As Freud points out in his essay "The Uncanny", this splitting, doubling and haunting, this ambivalent sense of familiar and unfamiliar, this coexistence of phantasy and the real, is the very experience of the uncanny. (148-149) ${ }^{34}$

In Maart's short story collection, the uncanny most prominently features in the ghastly weather conditions, which usually appear near the beginning of the different stories. With "The Green Chair", "Money for Your Madness", and "Ai, Gadija", three out of five stories start with a description of Cape Town's windy and wet weather. The following, for example, is the opening of "The Green Chair":

A warm breeze was hanging over Table Mountain and extended itself to Devil's Peak, located to the right of the mountain range. The southeaster was now blowing its last few breaths and a cool, sometimes cold, northwesterly wind would take its place by the month of May. Devil's Peak is not visible to those seeking it out from the streets of District Six, yet it looms in the backdrop, with horns ready to draw the will of those who surrender to it. District Sixers especially refer to the mountain and mean by their reference Table Mountain, or rather the Tabletop, and sometimes forget about Devil's Peak; but it never forgets

\footnotetext{
34 The characteristic of one aspect that is reflected or represented in the other, on the one hand, is the prime characteristic of Baudrillard's notion of the 'hyperreal', which I use as an analytic lens for my reading of Beukes' Moxyland in Chapter 3.2. The novel's 'ghostly' setting in a Cape Town of the near future links Beukes' hyperreal novel to the uncanny. The aspect of doubling as a trigger element of the uncanny, on the other hand, is central to my discussion of McNulty's Strange Nervous Laughter in Chapter 3.1.
} 
them. The wind which howls from its horns during moments when unsettled souls roam the streets capture the essence of that moment of weakness; once they gaze at the horns which seek them out on those weary days when shadows follow footsteps, they are overcome by its might. [...] Devil's Peak often puffs balls of smoke over Table Mountain when it is angry, challenging the mountain to chastise her children and when she fails to do so, he claims the spirit of those who tamper with circumstance. (Maart, Rosa's District Six 15)

Cape Town's (in)famous Southeaster, which is common from early spring (August/September) to late summer and early autumn (March/April), is generally responsible for clearing the sky and bringing fresh air during hot days (van der Velden). The first part of the descriptive passage thus sets the story's positive and - due to the richness in details, a typical characteristic of nostalgia (Stiebel, "Last Stop" 16; Boym 4) - the nostalgic atmosphere. It is striking, however, that Table Mountain and Devil's Peak, which together with Lion's Head form the three characteristic topographical features of Cape Town's city bowl, are established as clashing contrasts. According to the legend, Table Mountain, emblem of the 'Mother City', was "put there by a woman, millions of years ago, so that she could always feed her children and their children" (Maart, Rosa's District Six 62). This female, motherly landmark finds its counterpart in the masculine Devil's Peak that chides its citizens with "balls of smoke" for their misbehaviour (15). The latter, while an uncanny, symbolic harbinger of the neighbourhood's fate in general and the imminent ghostly apparition at the end of "The Green Chair" in particular, also hints at another phenomenon for which the Southeaster is responsible: the so-called "Table Cloth'. The Table Cloth is a massive cloud that hovers on top of Table Mountain and drapes over its edges. The cloud can descend into the city bowl in next to no time and cover the city in a thick layer of fog that lends Cape Town an eerie atmosphere (van der Velden). This becomes apparent in the opening lines of "Money for Your Madness", in which this particular phenomenon is included in the short story collection:

April afternoons in Cape Town were always unpredictable, and never more so than in 1970. The afternoon clouds would hover over Table Mountain until the wind lifted them and sent them tumbling down the cliffs, gracefully and breathlessly. When the clouds tumbled down the mountain everyone in District Six would stand still to watch the event. In a matter of minutes, the mountain would come to life, take on a character of its own, transform its setting, and change the weather completely, which would in turn change the mood of those who observed it. (Maart, Rosa's District Six 62) 
The rapid change of weather, similar to the previous excerpt, pre-empts the sudden turn of events at the end of story, which I will return to in more detail below. It is the uncanny character that these descriptions lend to the short story collection overall, I would argue, that set it apart from Akabor's Flat 9 where (apartheid) nostalgia's haunting character is of less significance as the younger generation is depicted as rejecting the older generation's nostalgic apartheid stories. These repeatedly ghastly and ghostly weather conditions, i.e. their doubling, is herald to the return of the repressed in the most Freudian sense ("The Uncanny"). This becomes apparent in the repeated resurfacing of the past in the fictional present in Maart's stories; for example, the recurring theme of rape in "Ai, Gadija" and the recurring theme of same-sex relationships both in "No Rosa, No District Six" and in "The Bracelet", or Rosa's continuous recurrence throughout the collection. The latter theme is, as I have already argued, and here the circle comes to a full close, inextricably linked to the question of Rosa's (un)reliability. (Un)reliability thus has to be seen as a narrative strategy which sees the (implied) reader, in an act of constant critical (re-)evaluation, actively participate in (re-)evaluating not only the validity and value of information presented but also questions with regard to the legitimation of the history and historicity of District Six more generally. On the one hand, the question of Rosa's (un)reliability forces the (implied) reader to deploy a reflective gaze and to retrospectively acknowledge the passionate love scene between Mrs Hood and Auntie Flowers, for example, as genuine rather than imagined. On the other, it is with and throughout this process of (re-)evaluation that the contemporaneity of extreme contrasts, which are established as one of the many charms of the District, are actualised both through the text and the (implied) reader's implicit act of solidarity in re-membering District Six and (a part of) its history. At the same time, Rosa's (un)reliability and the involvement it asks on the part of the (implied) reader can be seen as a (re-)negotiation of the District's immemorability, i.e. the danger of its gradual sinking into oblivion, that is prevented both through the text's very existence as well as every new read the short story collection is given.

While these narratological elements can be considered as predominantly concerned with establishing the collection's overall reflective nature, its nostalgic flair is further reinforced on other levels. This is already evident in the opening passage discussed in detail above. The English vernacular used for Rosa's account, together with non-standard Afrikaans, imitates the characteristic type of language used by District Sixers. According to Kay McCormick, the language used by District Sixers "can be seen as a spectrum with standard 
English at one end and standard Afrikaans at the other" and includes "the non-standard dialects of both languages as well as a mode of switching between them" (90). The narrative switches to standard English after the opening passage, as mentioned before, but the English vernacular is consistently used in Rosa's direct speech in the remainder of the collection. In addition to being a common denominator for the collection's stories on a content-related level, Rosa's language use thus provides a linguistic suture that runs through the different stories. ${ }^{35}$ The little girl, who would be in her early to mid-fifties today, ${ }^{36}$ furthermore becomes a carrier of this English vernacular from the fictional(ised) past to the present and with it a carrier of another of the District's flairs. At the same time, the opening passage constitutes a 'linguistic barrier' of sorts that the (implied) reader has to overcome and that forms, together with the implicit (co-)performance of Rosa's ritual and the consent to the pact of secrecy as suggested above, part of the (implied) reader's initiation to District Six.

Similar to Akabor's collection, borrowing is also frequently used for terms that express familial relations. Oemie, for example, is the Malay/Muslim term for mother or grandmother (Maart, Rosa's District Six 231). ${ }^{37}$ Borrowing furthermore occurs for more general terms of endearment such as bokkie, a diminutive meaning little dear or pet (231), or meisie and meisikind, signifying girl or girl child (230). In comparison to Flat 9, Rosa's District Six thus exhibits a broader variation with regard to borrowing in the expression of interpersonal relations.

\footnotetext{
35 For the sake of completeness, it should be noted that the English vernacular is not restricted to Rosa exclusively. It also appears in other characters' direct speech, particularly, but not exclusively, in emotionally critical moments.

36 Rocchi, in his article, takes into account the parallels between the protagonist Rosa and the author by fusing the two in the spelling: 'Rosa/Rozena' ("Intersecting"). In a personal interview, Maart revealed that she shares Rosa's individualism and independence of mind which indeed caused problems when she was a girl. Maart's grandmother, similar to the account on the collection's opening pages (Maart, Rosa's District Six 2), had to pressure the headmaster to accept her back to school after a formal suspension (Maart, Personal Interview). That being said, I would be hesitant to read Maart's short story collection as an autobiographical account, despite the parallels between little Rosa and the author's personal life. The collection, first of all, is not declared as an autobiography, which begs for its treatment as a fictional text. Furthermore, narrative theory strictly separates the author from his/her implied counterpart (see e.g. Rimmon-Kenan).

37 Other examples are Tietie, a Malay form of address for a family's oldest girl, Boeta, a Muslim form of reference to a family's oldest brother, or Motchie, a form of reference to an older Muslim woman similar to the more general term 'Auntie' (Maart, Rosa's District Six 19, 227, 231).
} 
Finally, borrowing, again analogous to Akabor's collection, also happens in the domain of food. Throughout the collection, there are a great number of references to typical Cape dishes such as Bobotie (i.e. a sweet and sour casserole of spiced minced meat that is baked with an egg- and milk-based topping) or Koeksisters (i.e. a type of 'doughnut' or 'cookie' - the word in fact derives from the Dutch word koekjie which means cookie - that is fried and then covered with a sugar-syrup icing; the Cape Malay version is sprinkled with coconut (A Dictionary of South African English)). In some occasions, a particular dish is linked to a specific event or date:

Pickled fish was a traditional District Six dish that was often eaten during the year but especially on Good Friday. On Good Friday, the smell of onions sautéing in oil and turmeric took over the streets; palm-sized pieces of fish would be fried then placed in the turmeric sauce, which contained not only tamarind and brown sugar but also vinegar as the extra, necessary ingredient to preserve the fish. The smell of freshly baked white bread, made by women, mostly, would waft in and out of homes as women got their knives ready, sharpened them against the paved step in their backyards and would cut bread to accompany the fish. The smell of oil, onions, fish and baked white bread enveloped District Six. [...] Christian families attended the three-hour mass in the morning, and returned home to eat their pickled fish. Muslim families went to mosque in the morning; they too would go home to enjoy their pickled fish and then would return to mosque at different times of the day. Food in District Six was not divided along religious lines. Many families kept halal homes because they had extended family that were Muslim, and eating was such an important part of District Six life, everyone wanted their friends and families to be able to eat at their homes. Good Friday was usually a quiet, somber day with no music echoing from the long-player or the radio. (16-17)

There are several salient aspects about this excerpt, which is taken from the "The Green Chair". Food clearly has a unifying function that highlights the neighbourhood's multiculturalism as well as aspects of home and (be)longing (on the former point see also Erll 44-45), very much like in Akabor's collection. This sense of (be)longing, though on a more personal level, also becomes evident in Rosa's visits to Jasmin and Latiefa in prospect of the customary "Redro fish paste sandwich" which she awaits with "her eyes big and bright and almost as large as her appetite" (Maart, Rosas's District Six 26). In comparison to Flat 9, however, there is a more prominent focus on cooking in Rosa's District Six. The processing of food and its sensory corollaries emphasise the aspect of nostalgic re-creation implied by cooking; the re-creation of a collective bond, 
but also of a distinct idiosyncrasy of the District's life. This element of recreation is also reflected in the temporal setting of "The Green Chair". The story sets in on the morning of Good Friday, 1970. This gives the story a temporal double-layer that conflates the story's fictional and the District's historical timelines. The weekend as a general temporal marker suggests a moment of transition from one week to the next. On a symbolic level, the weekend can thus be seen as a reflection of the imminence of the residents' evictions from the District, the bulk of which was effected throughout the seventies (Hart 126). The Easter weekend and its Christian significance more specifically suggest an additional twist: Good Friday, on the one hand, sees the crucifixion and death of Jesus and again mirrors the imminent destruction of the neighbourhood. Easter Sunday, on the other, celebrates the resurrection of Christ, which symbolically echoes both the fictional(ised) 'revival' of the District through Maart's collection as well as its (continuous) 'renaissance' with every new read.

The re-creative and connective quality of food becomes evident in the following example:

'I started to feel dizzy again in the afternoon ... and I still have this headache ... I know that Louisa thinks that Nana gets up to funny business ... I don't know, Zila.'

'Did you drink the rooibos tea with buju that Flowers left for you?'

'Yes I did. I had some of it this afternoon. Anyway, Zila, I better be off. I don't know if Nana made anything for supper.'

'You can always come here. Always. I make do with the little I have but there's always a pot on the stove. I'll come over tomorrow. That daughter of yours doan fool me.' Mamma Zila pulled a face then gathered her arms behind her back. (Maart, Rosa's District Six 94)

This is part of a conversation between Grandma Naidoo and Mamma Zila in "Money for Your Madness" (62-99), the collection's third story. The story follows Louisa, who, after a nervous breakdown more than fifteen years ago, lives under the rigid control of her mother, Nana. The former singer and actress, who gives all her attention to her yellow bird, Sunny, lives off her daughter's 'mad money' and refuses Louisa a social life. Mrs Naidoo, Louisa's grandmother, is ill and unable to help her granddaughter. When Rosa accidentally tells Louisa about her secret admirer, Cliffie, who keeps sending flowers that never reach her, Louisa finally decides to stand up to her mother. 
Reminiscent of the four lady friends and their Friday afternoon tea parties in Akabor's collection, the excerpt above displays a deep sense of confidence and solidarity between Grandma Naidoo, Mamma Zila, and (indirectly) Auntie Flowers that is inextricably linked to food. Despite her doubts regarding Nana's involvement in her fits of dizziness, Grandma Naidoo has confidence in Auntie Flowers' buju, i.e. a herb with calming effects (228), which in turn becomes a symbol for the solidarity between women. Mama Zila's invitation to dinner not only repeats this act of solidarity through food but also adds a distinct component of comfort to it.

Food and cooking thus serve as a spatio-temporal entanglement that lends both the stories in particular as well as the collection more generally a distinctly nostalgic tone and can be seen as another entanglement of the personal and collective (Boym xviii), through memories of both food and cooking. Similar to Akabor's collection, the reflective re-construction of District Six in Maart's short story collection is, however, not restricted to the domains of food, cooking, and language, as I will illustrate in the following discussion of the collection's setting.

\section{DISTRICT SIX AND CAPE TOWN IN ROSA'S DISTRICT SIX}

Rosa's District Six is replete with detailed accounts of both the District's and Cape Town's sensory wealth as well as their topographical and topological peculiarities, here boiled down to an essence:

People from the Eastern Cape say Cape Town is like a baby, it's either wet or it has wind. And perhaps it is like a baby: demanding, joyful and indulgent in the pleasures of the body, the pleasures of food, the pleasures of singing and cajolling [sic], which many say people do not celebrate in other parts of the country as they do in Cape Town. Cape Town is a city of sea, mountain, wind and sun; the pleasures of eating, drinking and conversing are certainly celebrated in District Six as though there is no tomorrow. Sayings like 'Tomorrow never comes' is [sic] always on the tip of the tongues of those who indulge in pleasures. Many would argue that District Six represents six pleasures: eating, drinking, dancing, cavorting, talking and rebelling - and that these are always accompanied by music. (106)

At first glance, Cape Town's wetness and windiness, two meteorological characteristics that set the city apart from Durban's hot, (sub)tropical climate as described in Akabor's collection, for example, may seem to introduce two tac- 
tile and unpleasant properties. On closer examination, however, the simile (i.e. "Cape Town is like a baby") rather serves to highlight Cape Town and, by way of deduction, District Six as 'living organisms'. This intention becomes even more evident, I would argue, with the subsequent enumeration of various pleasures that both Capetonians and District Sixers eagerly indulge in. It is, for example, noteworthy how food, drinking, and eating are picked up in the excerpt, even if in a more light-hearted context and in direct connection to other (types of) pleasures. More striking, however, is the fact that the description of the District emphasises acoustics and movement, establishing these as the basic parameters of the District's vibrancy. The importance of acoustics and movement is most ostensible in the significance of music and dancing and their relation to the (re-)construction of the subjectivities of District Sixers and District Six as a (lost) (home-)place.

"District Sixers", the (implied) reader is told at the beginning of "The Green Chair", for example, "had their own music", and this music:

was played in their home mostly on weekends, when friends brought their instruments and neighbours brought their rhythms, their food and their alcohol, to partake in grooving to the beat of their labour, their leisure and the time they gave to one another to take pleasure. To outsiders this was township music, a blend of sounds and rhythms that reflected the hustle and bustle of District Six [...]. (17)

Music, here, has as a distinct contextualising function that demarcates a reflectively nostalgic (be)longing to/for District Six as a (lost) home-place. The temporal encoding of these musical get-togethers as weekly events thereby suggests a circularity that echoes the reflectively nostalgic (re-)creation of District Six and its residents on a symbolic level. The spatial (or topographical) is further corroborated by the insider/outsider-rhetoric hinted at in the excerpt to which the more specific labelling as "township music" adds another socioeconomic (or topological) component.

The interconnection between the District's music as one of its distinct acoustic idiosyncrasies and dancing, which is only alluded to in the above passage by the "grooving to the beat", becomes clearer in the following scene. Rosa asks Uncle Lester to play a song on his pennywhistle, a request he willingly complies to: 
Lester took his pennywhistle from his pocket and played a short tune.

Rosa was bobbing away again. Lester now began to use the large dining room table as a drum. He kept the whistle in one hand and drummed with the other. Lester stood still and laughed as he saw how easy it was for Rosa to dance.

'She's not shy, hey, Uncle Lester,' Latiefa remarked.

'Oh no. Not at all,' he added.

'I like it better wit all der udder people playing ... wit der drums ... I like der goema,' she asserted.

Latiefa and Jasmin could not contain their laughter. The two young women were holding onto each other and laughed joyfully.

'Ja, you're [a] District Sixer, Rosa,' Lester asserted as he shook his head proudly. 'No one in District Six can live without their goema, huh.' (25)

Rosa's subjectivity and that of District Sixers more generally (with little Rosa as their proxy) are inextricably linked to music and dancing. Even though not in a gender-related fashion, Rosa's subjectivity is, in fact, a distinctly 'performative act' in the most Butlerian sense. In Gender Trouble, Judith Butler defines performativity as "a dramatic and contingent construction of meaning" and as necessarily subject to repetition that "is at once a re-enactment and reexperience of a set of meanings already socially established; and it is the mundane and ritualized form of their legitimation" $(190,191)$. It is, according to Uncle Lester, Rosa's goema dancing that 'makes' her or 'legitimises' her as a District Sixer. Uncle Lester's and Latiefa's observations about Rosa's ease and self-confidence at dancing furthermore highlight dancing as a positive "corporeal enactment" (189) of Rosa's subjectivity. If I (temporarily) deplete Butler's concept of performativity of its gender(ed) aspects, I by no means imply that they are inexistent in Maart's collection, on the contrary. I would like, however, to focus on a more abstract level where the (reflectively) nostalgic act that the sensitive and detailed depiction here entails becomes a 'performative act' in itself. It is by the text's 're-enacting' of various acoustic idiosyncrasies that the District is 'heard' (again), despite its material inexistence. At the same time, they can be seen as yet another creative tool in circumventing nostalgia's impossibility of a 'true' (or physical) homecoming due to the neighbourhood's physical inexistence.

Another acoustic idiosyncrasy besides the music is, for instance, the sounding of the Ospavat factory siren that structures the working day in District Six (Maart, Rosa's District Six 4-6; 83) and speaks to the neighbourhood's predominant working-class background. There also are the chiming bells of 
Cape Town's City Hall $(28,29,39)$, indicating the District's proximity to the city centre, or the prayers "echo[ing] from over the loudspeaker from the main mosque on Hannover Street" (120). The latter is reminiscent of the azaan resounding through Durban's Grey Street as described in Flat 9. The District's Muslim background, while certainly also another indication of its multicultural flair, is thus a direct link between the Grey Street area's and the District's shared Indian culture. This link, even if fleetingly, is established more directly with Grandma Naidoo asserting that her sons "are all in Durban living their own lives" as they want to avoid their sister, Nana, and her self-centred behaviour (91).

All these acoustic idiosyncrasies, including the linguistic ones discussed earlier on, the dancing, as well as the olfactory and gustatory stimuli of cooking, eating, and drinking focus on quotidian aspects of the District's life during apartheid, very much in the spirit of Njabulo Ndebele. Ndebele argues that South Africa's 'protest literature' of the 1950s, -60s, and -70s is "a highly dramatic, highly demonstrative form of literary representation" (37). Authors such as Alex La Guma or Dennis Brutus, Ndebele posits, promote "the spectacular contest between the powerless and the powerful" where "[m]ost of the time the contest ends in horror and tragedy for the powerless" (43). In doing so, protest literature followed a simple pattern: "the more brutality of the system is dramatized, the better; the more exploitation is revealed and starkly dramatized, the better. The more the hypocrisy of liberals it revealed, the better" (45). Ndebele, however, highlights the need for the less spectacular. It is, according to him, "[b]y rediscovering the ordinary" that people are reminded of the fact "that the problems of South African social formation are complex and all embracing; that they cannot be reduced to a single, simple formulation" (55).

It is this complexity, I would argue, that lies at the heart of the collection's (at times) nostalgic but (always) critical (re-)construction of people's lives in District Six during the height of apartheid, and which explains the scarcity with which the spectacular aspects of the apartheid regime surface in the short story collection. The already ongoing demolition of houses in District Six, for example, is mentioned once and only in passing:

Sid observed that some of the buildings had been knocked down at the end of Caledon Street and sighed aloud for he knew why. There were chunks missing, like from a partly eaten loaf of brown bread, and he looked at the surrounding buildings, wondering how they supported themselves. He was now on Castle 
Street, and the castle lay right before him, as a reminder of who he was and why he lived in District Six. He held this thought, his face assuming a contemptuous look, for a few seconds. His mouth curled with sorrow and he looked behind him at the site upon which District Six was erected. (Maart, Rosa's District Six 45)

It is striking how the District's colonial origins as a former slave quarter, its volatile present, and depressing future are entangled in this excerpt. And yet, the comparison of the demolished houses with "a partly eaten loaf of bread", which serves to downplay the importance and impact of the destructions and the District's imminent future, suggests a moment of strength, even if only a fleeting and symbolic one.

Then there is Gadija's husband, Abdul, "who had been serving time on Robben Island since 1964 for conspiring to overthrow the government" (102) and the two (white) policemen, van der Merve and a young constable, who bring home Gadija's sister, Gairo, and inform the family about her being raped (124-126). The policemen's "stepp[ing] into the house without an invitation" and van der Merve's "light[ing] a cigarette and smirk[ing], fully aware that no one in Motchie Gafsa's house smoked" (124) become two powerful reminders of apartheid's fundamentally bioculturalist rational, which inevitably turned District Six into a highly 'suspicious' place. This fundamental 'racially coded suspicion' becomes particularly evident in van der Merve's decision to take down the names of all the men who have gathered in "the small wooden cabin in the backyard" of Motchie Gafsa's house for choir practice (Maart, Rosa's District Six 122), stating to his young colleague: “They are in the men's Muslim choir, so they say, but who knows, hey, who knows?" (126). Such racially driven chicaneries stand in stark contrast to the collection's brief references to gang culture (135) and stabbings (186-187) where, in reflection of the District's reputation as a crime-ridden place, the police are nowhere to be seen.

The collection's last story, "The Bracelet", deals with both apartheid's anti-gay laws as well as the phenomenon of 'passing', which signifies a person being accepted or even classified as white despite being coloured, in fact, and thus 'benefitting' from white people's privileges. The story sets in on the evening of the annual dinner that Caroline and Nathaniel Chambers host for Rosa's family as a thank you for Mama Zila's saving the Chambers's daughter, Victoria. Shortly after the two families get together, Caroline learns about Nathaniel's meetings with his (male) lover in a park in Tamboerskloof. It is during this altercation between husband and wife that Caroline (indirectly) makes 
reference to the Immorality Act of 1957 and the Immorality Amendment Act of 1969:38

'[...] My God, the gayest place you could find. Are you out of your mind? What if the police caught you having sex with a man ... in public. They would have come knocking on this bloody door ... I would have to answer questions about my moffie husband ... I would have to bail you out ... I would have to save your bloody moffie ass from jail.' (194) ${ }^{39}$

Carolyn's argument, which relies on the hypothetical, framed by the "what if", inextricably links Nathaniel's 'queerness' to the question of knowledge. Public knowledge of Nathaniel's gay relationship would effectively destroy the family's social standing that, in turn, is built partly on Carolyn's 'knowledgeable' position as "a university-educated schoolteacher" (165), and partly on Nathaniel's ignorance (or not knowing) about his being coloured. Carolyn's university education resurfaces during the marital dispute. When Nathaniel quotes the opening lines from Christopher Marlowe's "The Passionate Shepherd to His Love", ${ }^{40}$ Carolyn responds condescendingly: "Well done, Nathaniel. Oh, aren't you clever. I see my university education has served you very well. So, you didn't just lie in bed with me, lie there and cheat about who you are, you have actually learnt something from me" (Maart, Rosa's District Six 195; my emphasis). Interestingly, Nathaniel's and Carolyn's contrasting characters - he is sensitive and impulsive; she is cool and rational - are reminiscent of the shepherd's passionate impetuosity as opposed to the lover's implied hesitance and aloofness. The seeming distance between the poem's lyrical I and addressee is reflected in Carolyn's pronominal use (me versus you) with which she places herself above Nathaniel whom she establishes as the beneficiary of her education. The theme of knowledge and its various implications is thus cleverly deployed to establish more salient aspects of the District's (internal) social inequalities.

These inequalities are also reflected in the District's topography:

\footnotetext{
38 The Immorality Act of 1957, on the one hand, prohibited sexual intercourse between whites and non-whites in general. The Immorality Amendment Act of 1969, on the other, declared sexual intercourse between men a statutory crime and introduced the infamous 'three men at a party' clause that sought to forbid public (sexual) intercourse between men (“LGBT Legislation"; Gevisser).

39 Moffie, according to Maart, is a shortened form of 'hermaphrodite' (Rosa's District Six 231).

40 The poem, which opens with the lyrical I's request "come live with me, and be my love", comprises a list of things the speaker promises to fulfil should the lyrical I's beloved agree to the initial request.
} 
Carolyn and Nathaniel lived on the upper side of DeVilliers Street. Uppersiders lived along the border between District Six and De Waal Drive. Roeland Street was the lower part of De Waal Drive and met several District Six streets, quite against the better wishes of those who cherished the notion of living on its border. DeVilliers Street had an upper side only to those who named it such, to suit their purposes. This upper side on DeVilliers Street was composed of a row of seven houses, close to Roeland Street, which were occupied by families who carried themselves as though they were not Black and certainly not Coloured, as the latter was more descriptive of the social, ethnic and cultural particularities of District Sixers. (Maart, Rosa's District Six 163)

This topographical distancing is further corroborated by the washing lines of District Sixers "strung with rope [...] whilst uppersiders exhibited few items on their lines" (164), which symbolically weighs the burdens of the according lifestyles. Another example is what could be called the 'food line' that exists between District Sixers and Uppersiders. Uppersiders are said to eat English and Dutch food since " $[t]$ heir palates were not trained to crave the spiciness of the District Six dishes nor desire the saucy, passionate performance of hands scooping curry with roti or tongues licking warm cooked desiccated coconut out of syrupy ginger and cardamom spiced koeksisters" (165). This, of course, once again reiterates the importance of food and eating in fostering a sense of (be)longing, which is also spatially marked. Nathaniel, finally, behaves differently towards District Sixers depending on his wife's absence or presence respectively: "Nathaniel made an effort to speak to his neighbours, but when he was accompanied by Carolyn, he ensured that he stayed a safe distance from the District Six residents, whom he greeted with his eyes; he did not utter a word to anyone she disapproved of in her presence" (166). All three examples thus speak to an incorporation of an ambiguous subjectivity in the context of District Six, particularly at the height of the apartheid regime, and people's knowledge or unawareness about their own and other people's "true ancestry" (164) plays an important role with regard to this ambiguity and the (multiple) social inequalities it implied.

In Nathaniel's case, this multiple marginalisation is further increased with his coming out to his parents that is marked by an unexpected turn of events. Mr Chambers, whose memories are triggered by Nathaniel's transgender boyfriend, not only reveals his own bisexuality, but also his 
'jumping the colour line'. ${ }^{41}$ It is worth noting how Mr Chambers's (unexpected) coming out is, once more, connected to goema dancing and thus to the collection's recurring theme of acoustics and movement more generally. His repeated chanting of the dance's name, "Goema, goema, goema..." (Maart, Rosa's District Six 220, 221), serves as a 'prologue' of sorts to his confession to which the dancing and thus the 'corporeal enactment' of being a District Sixer follow automatically. "That is", Mr Chambers asserts, "how we used to do it in District Six in those days, hey?" (221). Munro rightly argues that Mr Chambers' admission entangles being queer with being coloured and that the story thus:

complicates the temporality of the 'coming out story', which is usually a progress narrative in which the gay subject moves away from the closeted past into a more truthful future. Here, coming out makes the family look back, unearthing a memoir within the memoir, so that 'writing history' becomes a collective, layered event. (138-139)

Connected to this temporal layered-ness of the District's history, however, is the question of its 'durability' and 'documentability' which is repeatedly raised by different kinds of diseases that appear throughout the collection: $\mathrm{Mr}$ Chambers's Alzheimer's disease, little Rosa and her suffering from hyperactivity disorder and an undiagnosed disease that affects the use of her hands, as well as Louisa's (alleged) madness. These examples and their function as to the collection's fictional(ised) (re-)creation of District Six and its past will be the focus of the following section.

\section{Seizing the (Painful) PAst}

The question of the 'durability' and disruption of (personal) history is most prominent in Mr Chambers' condition. Early on during Nathaniel's and Matthew's visit Mrs Chambers explains: "His day-to-day memory is not so good, you know. His mind is a little gone. He is fine most of the time ... he just blurts things out sometimes but does remember things" (Maart, Rosa's District Six 214). Alzheimer's patients, particularly in the early stages of the disease,

\footnotetext{
${ }^{41}$ In that respect "The Bracelet" and Wicomb's Playing in the Light have striking similarities. There are further parallels between the two texts than their dealing with the sensitive topic of 'jumping the colour line' and the stigma of coloured identity. Both texts, for example, deploy the Alzheimer's disease/dementia, among other things, to address the issue of memory's 'faultiness'.
} 
typically display difficulties in recalling more recent events while their older memories remain intact. The progressive cognitive impairments that the Alzheimer's disease entails become a means to symbolically (re-)negotiate aspects of (im)memorability with regard to the broader history of District Six. The imbalanced affectedness of the short- and long-term memory can be seen as establishing memorability and immemorability as the two extremes of people's (in)ability to remember. In-between the two poles there is a whole memory spectrum. For Akabor's collection, I argued that the question of (im)memorability is essentially an inter-generational one. The younger generation is increasingly confronted with the problem of their parents' and grandparents' Grey Street becoming an immemorable place for them, i.e. a place they cannot (possibly) remember as they experienced it only partly or not at all. Maart's collection deals with this aspect of (im)memorability in the Chambers' case. Mr and Mrs Chambers' District Six is an immemorable place for Nathaniel as he grew up in Salt River (164), unaware of his coloured background and profiting from the (white) privileges that came with growing up there. Mr Chambers' confession deeply shakes Nathaniel's sense of identity, which is alluded to by Nathaniel's repeatedly throwing up in his parents' backyard (223-224). The story's focus, however, is on the older generation's memorability of District Six.

The exploration of the District's (im)memorability in connection to aspects of disease, furthermore, links the act of remembering to questions of discomfort and pain. It is this agony, both psychological and physical, that makes (certain) memories of the District's life (potentially) immemorable, i.e. too painful to be remembered. Elaine Scarry, in her book The Body in Pain, argues that " $[w]$ hatever pain achieves, it achieves it through its unsharability, and it ensures this unsharability through resistance to language" (4). At the same time, Scarry asserts that "the act of verbally expressing pain is a necessary prelude to the collective task of diminishing pain" (9). With the theme of disease repeatedly recurring in the narrative, the (more) unpleasant and traumatic sides of remembering District Six seem to be consciously addressed and, ultimately, a process of mourning initiated.

Freud, in "Beyond the Pleasure Principle", describes a child's pleasure in repeatedly playing 'disappearance and return' with his toys as a way to compensate for the occasional absence of his mother to whom the child is particularly attached (14-15). The complete game goes as follows: The child throws a wooden reel that is attached to a string out of his sight accompanying the act by an expressive 'o-o-o-o' for 'fort' (i.e. 'gone'). Following this, the child pulls 
the reel back by means of the string, celebrating its reappearance with a delighted ' $d a$ ' (i.e. 'there'). Freud argues that "[a]t the outset he [i.e. the child] was in a passive situation - he was overpowered by the experience; but, by repeating it, unpleasurable though it was, as a game, he took on an active part" (16; original emphasis). By 'voicing' the more unpleasurable and traumatic facets of the District's past, Maart's collection can thus be seen as 'taking on an active part' in (re-)capturing District Six as a (lost) home-place.

This aspect of 'tangibility' becomes most evident in little Rosa's condition that is, for example, addressed during her visit at Latiefa's and Jasmin's house:

'Rosa, show me your hands,' Latiefa asked.

'No!' the young child exclaimed.

'Rosa, I just want to see. You can click your fingers now ... So it's not sore then ... or stiff?' Latiefa was speaking slowly so as to encourage the child to share the details of her undiagnosed condition. Rosa did not reply. 'So Mr Henson doesn't bother you anymore, huh?' Rosa did not reply and stood with her hands behind her back. 'Did Mamma Zila get you to wear the book around your neck so that you won't write on the walls anymore, Rosa?' Rosa still did not reply.

'What the doctors say, Rosa?' Jasmin asked as she bent down to Rosas height.

'Nothing! ... Is not contay ... ay ...,' the child stammered.

'Contagious, contagious ... is that the word?' Latiefa asked.

'Yes, dat's der word. Der doctor say dat,' Rosa replied. 'It means dat noborry else can get it from me,' she said, looking wide-eyed at both Latiefa and Jasmin.

'Rosa, we are not worried for us, we are just worried for you sweetie,' Latiefa said reassuringly. (Maart, Rosa's District Six 22)

Rosa's seemingly improved condition in the above excerpt, which is set in mid-April (16), is in stark contrast to her difficulty in moving her hands in July, i.e. South Africa's winter, reported elsewhere in the collection (183). Despite the fact that her condition remains "undiagnosed" (22) throughout the collection, which in turn suggests a more psychosomatic origin of the disease, it seems that Rosa is suffering from a (chronic) rheumatic-like disease. ${ }^{42}$ Rosa's painful and at times stiff hands, which make it difficult for her to grasp things, can be seen as an allusion to the general difficulties in, and (im)possibility of,

\footnotetext{
42 In a personal interview, Maart also talks about the traumatic effect the forced removal from District Six had on her personally. Maart's family was relocated on 4 August 1973. After the family's removal from District Six, Maart would break out in hives every year on 4 August. That is until she decided to write a story about District Six: "No Rosa, No District Six". Together with the publication of the story, the hives disappeared (see also Maart, "Philosophy" and Rozena Maart).
} 
(accurately) keeping/preserving memories but also the painfulness that accompanies memories of District Six in particular. The latter is symbolically reflected in the little book Rosa is wearing around her neck that bespeaks the multiple 'burdens' of Rosa's disease, being a District Sixer, as well as the dealing with painful memories of a lost home-place. Jasmin's inquiry reveals that Rosa's condition is not infectious, and thus furthermore speaks to the stigma that seems to come with the inexplicable disease, an aspect that is corroborated by both Rosa's unwillingness to show her hands and Latiefa's reassurance that Jasmin's and her concern is for Rosa and not themselves. On the one hand, Rosa's defensive reaction alludes to the stigma connected to South African coloured identity. On the other, Rosa's refusal can be seen as a sign of her strength of character and agency. In writing down/about the things she sees and experiences, Rosa becomes a chronicler of the District's contemporary events, so to speak, with her little book containing a whole number of accounts similar to the collection's opening pages. In view of Rosa's condition, these accounts are necessarily linked to the physical pain that the holding of a pen and documenting of her observations and experiences involve for Rosa. At the same time, the reflectiveness of Rosa's (written) accounts in particular and, by way of implication the collection's short stories more generally, implies the initiation of a process of mourning.

Dirk Klopper compares Boym's two forms of nostalgia with Freud's concepts of mourning and melancholia ${ }^{43}$ and argues that:

Like restorative nostalgia, melancholia transforms time into space in an attempt to hold on to what has been lost, and like reflective nostalgia, mourning transforms space into time by letting go. Both conceptual pairs contain a relation of inversion conforming to the rhetorical figure of the chiasmus, a mark that appears to fix a stable relation in place but in fact describes a potentially unstable relation. (148)

It is by Rosa's working through, with, and beyond her pain that her documentations become a form of mourning the loss of District Six as a home-place. This more symbolic (or psychological) aspect is linked to the collection's ambiguous narrative (spatio-temporal) structure. Similar to Wicomb's Playing in the Light, there is the question of the identity of the collection's third-person

\footnotetext{
${ }^{43}$ In his essay "Mourning and Melancholia", Freud discusses two forms of longing: mourning and melancholia. While the former implies the dealing with and getting over the grief of what has been lost, the latter does not relinquish its hold on the object of loss and thus refuses personal improvement.
} 
narrator. ${ }^{44}$ Despite the fact that the narrator's identity ultimately remains unresolved, there are several indications that suggest it is adult Rosa. The thirdperson narrator has (intimate) insider knowledge that can only come from someone with (unlimited) access to District Six. Rosa, who is able to go in and out of people's houses at liberty, as "nobody locked their doors anyway" (Maart, Rosa's District Six 6), has that kind of access and unashamedly makes use of it. Rosa, furthermore, constantly reappears throughout the narrative, particularly in crucial situations. At the same time, there is a gradual 'zooming out' or distancing (along the near/far-axis) with regard to the collection's narrative perspective. Rosa is the first-person narrator (and thus focaliser) of the opening account and then becomes the main focaliser for the rest of the collection's opening story after the shift from a first- to a third-person narrative. For the remainder of the collection, Rosa also is no longer the main focaliser of the various stories but nevertheless remains a continuous presence. This gradual (spatio-temporal) withdrawal suggests an emotional distance that the narrator has gained in relation to the difficult topic at hand and her ability to retrospectively shed (new) light on District Six. A reflective re-visiting and reevaluating of both the District's positive but also, and more importantly, its negative and traumatic sides by adult Rosa would then speak to a process of mourning that is initiated by the collection. This process of mourning is inextricably linked to the finding of (an authorial) voice, reflected, for example, in Rosa's need to write and, consequently, her (written) accounts.

The most momentous symbolic expression of aspects of voicing (and therein included aspects of silencing in turn) can be found in the escalation of Nana's unremitting contention with her daughter, Louisa, at the end of "Money for Your Madness". The dispute between mother and daughter rekindles once more when Louisa catches Nana red-handed attempting to add her daughter's psychotropic drugs to Grandma Naidoo's tea (95), a discovery that solves the mystery of her grandmother's spells of dizziness. The subsequent physical altercation between the two women sees Nana's retreat to her bedroom and thus her loss of voice (or her silencing). Nana's loss of voice is not only reflected in the fact that she used to be a singer and actress but also in Luisa's subsequent act of vengeance in which she catches and kills Nana's bird, Sunny, with her mother's "favourite kitchen knife" (98). In killing Sunny, Louisa re-gains her agency in a most literal sense and her behaviour after the assassination further attests the act's symbolic significance:

${ }^{44}$ For a discussion of the narrative structure of Wicomb's novel see Klopper (149-150 in particular). 
Sunny's head now rested on the counter, limp and severed from the rest of his tiny-feathered body. Louisa had no blood on her hands, none at all. She turned her head a few times, from side to side, as if she was asking herself something deep and personal. She placed the knife on the wooden block in the backyard and glanced at the blood on its edge. Louisa tilted Sunny's head up and down. Sunny would never chirp again. Her forefinger now had blood on it. She held it up to the sun, then moved towards the wall, where she made several marks with her finger. She walked over the logs of wood and looked over her shoulder to see if he was still where she had placed him, beside the knife on the wooden block. There was now a trail of death to where he had sat and chirped and sometimes hid. Louisa pushed the blocks of wood away to find the one at the bottom, where she left another bloody print. She had now touched and stained with blood almost every piece of chopped wood that he would sit on. She motioned her hand to resemble his shape and made his sound as he lay there lifeless on his back with his neck gaping open and with his eyes fixed on her. For a moment she stopped, almost convinced that she heard him, and then mimicked him again, and again, until her own sound convinced her that she had finally copied his chirp - and for once, he had to bear witness to her call. (98-99)

Repeatedly imitating Sunny's chirp and reproducing the bird's shape with her hand gestures, Luisa takes over Sunny's subject position. This 'embodiment' is anticipated by their visual resemblance: Sunny, as the name suggests, is a "yellow budgie" (69) and Louisa is still wearing the yellow dress she has put on earlier to go for a walk with Grandma Naidoo $(78,97)$. This 'yellowness', reminiscent of the yellow wallpaper and its symbolic function in Charlotte Perkins Gilman's short story ("The Yellow Wall-Paper"), suggests an element of ambiguity and instability. In contrast to Perkins Gilman's protagonist whose mental ailment deteriorates over the course of the story, ${ }^{45}$ Louisa, similar to Azure in K. Sello Duiker's Thirteen Cents, is able to return to a certain level of (mental) stability and cleanliness. This becomes apparent at the end of the story where Louisa decides to meet her admirer, Cliffie, after dinner for which she changes into a white dress before joining her grandmother for dinner at Mama Zila's

\footnotetext{
45 "The Yellow Wallpaper" circles around an unnamed first-person narrator who, due to her post-natal depression, is taken on a summer vacation to a remote house by her husband where she is instructed to rest. The narrator is particularly upset with her husband's rational behaviour. He belittles both her condition and her views, contrasting with her sensitivity and creativity. Isolated in her room, the narrator becomes interested in the yellow wallpaper. Her initial interest in the wallpaper's pattern and colour soon turns into an obsession and the narrator eventually loses her mind, locking herself into her room and tearing the paper from the walls.
} 
(Maart, Rosa's District Six 99). In view of the callousness of the act of violence Louisa commits, however, this recovery is an unstable one at best. The blood trail Louisa leaves not only (spatially) marks her taking over of what used to be Sunny's territory, but it can also be seen as an enactment of the suffering she has endured under her mother's oppression. It is by (literally) 'dis-embodying' Sunny, the bird is reduced to its head that is then played with, that Louisa is able to take (temporary) control of her mental dis-ease. On a more abstract level, this act of 'dis-embodiment' can be seen as a proxy for the District's history where the forced removals equal the dis-embodiment/ dis-placement of the people. All that the former residents of District Six were/are left with after the forced removal and the neighbourhood's subsequent demolition were/are their memories and their pain - their heads, so to speak.

In contrast to Akabor's Flat 9, where the aspect of apartheid nostalgia is present but less prominent as the collection rather focuses on a survey of postapartheid demographic and economic changes and their effects on the younger generation in the form of a reflective post-apartheid nostalgia, Maart's Ro$s a^{\prime}$ s District Six displays a more multifaceted form of reflective apartheid nostalgia. This nostalgia is what Hook calls "fantasmatic" (182), given the fact that District Six no longer physically exists. What thus turns out to be an imaginative remembering of a (lost) home-place ultimately proves to be a (to some extent uncannily) resurfacing of a repressed traumatic past. This traumatic past, in turn, is linked to a process of mourning which is (un)consciously initiated on a creative level through the (literary) text. The reflexivity of this (at times) nostalgic process of mourning thereby happens in several ways. Rosa's (un)reliability, on the one hand, which is linked to questions of secrecy and legitimation, forces the (implied) reader to actively take part in the constant (re-)evaluation of the given information. This replicates the collection's generally retrospective (or nostalgic) character on a more structural (or narratological) level. On a more content-based level, on the other hand, the importance of acoustic idiosyncrasies and of movement within District Six (most prominently through music and dancing) highlight the neighbourhood's vitality. While this certainly has to be understood as a creative form of resisting the District's physical inexistence, it also stresses the ordinary over the spectacular (Ndebele), which is (un)consciously marginalised in the narrative. The aspect of agency, which is indirectly (re-)gained on a creative level by this marginalisation, becomes more apparent in the recurring theme of disease, most prominently in the form of little Rosa's rheumatic-like condition. Rosa's necessity to write 
down/about events and experiences despite the difficulty using her hands not only (symbolically) secures the District's continuing historicity, but the verbal expression that Rosa's writing gives to the District's past also initiates a mourning process.

Both texts, though in different ways, thus engage with what Hook, based on Freud, calls "apartheid nachträglichkeit" (186; original emphasis). According to Hook, apartheid nachträglichkeit firstly implies a delay in the past's effects on the present. Secondly, the present, which is constantly threatened by the past, cannot but be of an uncertain and unstable nature. And thirdly, apartheid nachträglichkeit involves the possibility of a temporal reversal from the future back to the past and thus the possibility of a retrospective (re-)assessment thereof by potential future(s). This possibility ultimately bears both risks and chances of changing the past's meaning, of changing the past into a 'future past' (186-187). ${ }^{46}$ Akabor's Flat 9, on the one hand, engages with apartheid nachträglichkeit through the lens of a younger generation whose reflective post-apartheid nostalgia critiques the constraints of their parents' past on their present and (potential) future. Maart's Rosa's District Six, on the other, can be seen as (un)consciously confronting apartheid nachträglichkeit by initiating a reflectively nostalgic process of mourning. Neither of the texts, I would argue, thereby runs the risk of creating a future past.

Pamila Gupta, in her article "The Future(s) of (Colonial) Nostalgia or Ruminations on Ruins", asks:

If nostalgia (for something lost) produces utopian longings (for change, for hope, for possibility), can we think about this (ordinary) affect as a catalyst for individual and collective action that is not always reductively conservative (war, genocide, xenophobia), but rather as potentially liberatory through its articulation of the sensory, the sublime, and the sloppily sentimental, all at once?

Both Akabor's and Maart's short story collections and their use of nostalgia as a means to project their (be)longing to/for a (lost) (post-)apartheid place, including both wished-for changes and hopes, as well as the articulation of

\footnotetext{
46 Ashraf Jamal, based on Hal Foster, uses the term "future-anterior" and suggests: "In attempting to grasp new and emergent (hybrid) moments in South African literature it seems that one must forego linear logic. Foster's concept of a future-anteriority certainly serves us well in this regard, for it allows us to bypass conventional categories such as struggle literature and post-apartheid literature, and, so doing, generate a more lateral and untimely schema" ("Bullet" 13). This non-linear, or entangled, temporal conception, Jamal rightly points out (14), reminds of Mbembe's time of entanglement, discussed in the introduction.
} 
(im)possibilities in a critical and reflective way, I would argue, show that we can. For, as Dlamini argues, "the irony about nostalgia is that, for all its fixation with the past, it is essentially about the present" (16) and, as Boym would doubtlessly want to add, about potential futures. 


\section{CHAPTER 2: MAD(DENING) PlaCeS}

Madness has become man's possibility of abolishing both man and the world and even those images that challenge the world and deform man. It is, far beyond dreams, beyond the nightmare of bestiality, the last recourse: the end and the beginning of everything. Not because it is a promise [...] but because it is the ambiguity of chaos and apocalypse: Goya's Idiot who shrieks and twists his shoulder to escape from the nothingness that imprisons him - is this the birth of the first man and his first movement toward liberty, or the last convulsion of the last dying man?

- Michel Foucault, Madness and Civilization. (267)

Key to understanding [post-apartheid South Africa's] reality is to see racism on a spectrum: at one end you will find the most brutal physical attacks motivated by racism, and at the other end you will have a cluster of manifestations of racism and white privilege that seem innocent but which should properly be called out as part of racism's spectrum.

- Eusebius McKaiser, Run Racist Run. (112)

In what follows, I explore notions of 'madness' as an engagement with, and critique of, South African whiteness in Johan van Wyk's Man Bitch and K. Sello Duiker's Thirteen Cents. Madness has indeed had "many faces" throughout history (Pietikainen 3), and both the changing perception of its socio-historical and -cultural significance as well as its theoretical implications have prominently been analysed. ${ }^{47}$ Among the many studies, Michel Foucault's Madness and Civilization has doubtlessly become "the theoretical paradigm of a major current in the studies of madness and society" (Veit-Wild 1). In a nutshell, Foucault argues that the Thirty Years' War (1618-48) was followed by an era of "great confinement" (35). As "a "police' matter" and "an imperative of labor" to counteract the economic crisis of the seventeenth century $(43,46)$, European states began to send the socially aberrant to prisons, hospitals, and mental asylums. Accordingly, society's attitudes towards madness began to shift. Besides the established association with the realm of 'unreason', the

47 See e.g. Feder; Foucault; Porter; Keller; and Pietikainen for a socio-historical and -cultural approach to madness. For a psychoanalytic approach see e.g. Derrida, "Cogito"; Felman; Freud (e.g. "Beyond the Pleasure Principle"); Freud and Breuer; Lacan (The Psychoses and Écrits); and Laing. 
madman was, according to Foucault, "included in the proscription of idleness" and morally stigmatised because "he cross[ed] the frontiers of bourgeois order of his own accord, and alienate[d] himself outside the sacred limits of its ethic" $(53,54)$.

The historical accuracy of Foucault's study has rightly been questioned. Among other aspects, Petteri Pietikainen, in Madness: A History, refutes Foucault's idea of a 'great confinement' in Europe between 1650 and 1800 and shows how such an era only began in the nineteenth century when Foucault believed it to be already over (79-80). Nevertheless, Foucault's analysis is seminal in that it establishes madness as a 'social construct', the meaning of which shifted and changed over time. What appears to be a historical study at first glance proves to be, in fact, "the philosophical search for a new status of discourse, a discourse which would undo both exclusion and inclusion, which would obliterate the line of demarcation and the opposition between Subject and Object, Inside and Outside, Reason and Madness" (Felman 42; original emphasis). Madness is then - and this is what makes it such a powerful analytical tool - a figure of thought, a Denkfigur, that offers an entry point to the negotiation of the various oppositions Shoshana Felman associates with Foucault's "philosophical search".

It is such an opposition that Foucault establishes in the first epigraph to this chapter, in which he sees madness as a potential metaphorical (re-)birth or death of the madman and it is this idea that I take as the starting point of my analysis of the mad(dening) post-apartheid subject in Johan van Wyk's Man Bitch and K. Sello Duiker's Thirteen Cents. "While [madness]", Flora Veit-Wild posits in Writing Madness, "can mean an agitated state of mind such as frenzy, rage, rapture or recklessness, it is also used as a synonym for insanity, that is of mental disorder, a psychopathology" (2). The adjectives 'mad' and 'maddening', which I use as analytic pillars for this chapter, bear the same range of meanings Veit-Wild establishes for the noun. The Oxford English Dictionary defines the pronoun 'mad' as "[s]uffering from mental disease; beside oneself, out of one's mind; insane, lunatic. In mod. use chiefly with a more restricted application, implying violent excitement or extravagant delusions: Maniacal, frenzied". Its derivative form "maddening' signifies "to become mad" or "to make mad; to drive out of one's mind; to excite to frenzy or uncontrollable anger; [...] to irritate, annoy, vex". The terms' link to the notion of place, however, needs some explaining.

Place here is meant both in a geographical as well as a mental or psychological sense. On the one hand, this chapter deals with real geographical plac- 
es, i.e. Durban's Point Road area in Johan van Wyk's Man Bitch as well as Cape Town's Sea Point and Green Point in K. Sello Duiker's Thirteen Cents, and their depiction in fiction. On the other hand, the (mentally destabilising) effect of both fictional(ised) geographical locations on the books' protagonists are considered. The description of a place as mad or maddening thus not only entails the evaluation of a place's state as depicted in a literary text but also the effect that a fictional(ised) place's development and progress - or, for that matter, the lack thereof - has on a fictional character. The label mad or maddening may imply a more critical stance towards the place in question. It does, however, not necessarily imply a purely negative assessment as I will show in my analysis of Duiker's novel, where the madness of both the place and the protagonist can be seen as having more positive and creative implications.

The notion of place that I apply in my study, furthermore, is similar to Foucault's understanding of madness. As seen in the Introduction, I consider place to be a specific realisation of social interactions and interrelations and these social interactions and interrelations are, a priori, multi-layered and in continuous transition. My understanding of place, which follows Doreen Massey, is thus of as an (inter)relational and fleeting nature as Foucault's concept of madness. The two concepts indeed complement each other. While the concept of place accounts for the actualisation of interpersonal relations - both between different individuals (or fictional characters) as well as an individual (or fictional character) and society (or social institutions) at large - within the 'fictional reality', the notion of madness can be seen as the intrapersonal (or psychological/psychopathological) expression of, and reaction to, these social relations. Madness, which "in the fabric of a text and through the very act of writing [...] is at work, stirring, changing place, and wandering away" (Felman 55; original emphasis) thus becomes a way of 'capturing', even if only as a snapshot within a particular space-time, an individual's - and by extension a society's - degree of dis-content and dis-ease. It is here that the notion of 'alienation', the original term for madness in the nineteenth century when "mental illness was commonly understood as the insane persons' alienation from themselves (their true identity) as well as from their social environment" (Pietikainen 107), takes effect. This idea of the mad(dening) subject as alienated/alienating is thus of a decidedly spatio-temporal nature. It not only highlights the interconnectedness of madness and place, but it also entails the mad(dening) subject's spatio-temporal dis-placement, a spatio-temporal Verfremdung, that the German word for madness, Ver-rücktheit (literally displacement), already contains. Where suitable, the latter, more psychological 
and psychoanalytical side of madness will be complemented by appropriate theorisations (particularly Fanon's Black Skin, White Masks).

Foucault's 'history' of madness, which was the starting point of my reflections, is of a decidedly European scope. Africa, the 'dark' continent, has been delimited as "a space of savage violence and lurid sexuality, but also as a space of insanity" (Keller 1) since colonial times. The 'scientific racism' that ensued throughout Europe's colonies in Africa stigmatised the African subject as 'the mad Other'. ${ }^{48}$ According to Veit-Wild, "the political situation in Africa is so full of absurdities, monstrosities and grotesque aberrations that it demands a literary response reflecting the innermost madness of this very situation and the structures ruling it" (2). ${ }^{49}$ In the South African context, these "absurdities, monstrosities and grotesque aberrations" manifested themselves through apartheid's bioculturalist racial stratification which secured 'white supremacy' and, among other mechanisms, was implemented via such bizarre methods as the so-called 'pencil test' (Posel, "What's" 59). Even after apartheid's demise, these racial categorisations are still common sense to the extent that current discourses of 'whiteness' and 'white supremacy' are considered to inhibit the full development of South Africa's black society (see Haffajee 1-29).

South African whiteness has been widely discussed both within the field of Critical Whiteness Studies and beyond. ${ }^{50}$ Melissa Steyn, on the one hand, has argued that the white subject position needs to be reconsidered within South Africa's post-apartheid context where political dominance has changed more radically than social and economic powers. This renegotiation, according to Steyn, needs "to redefine and complicate identities for those interpellated by discourses of whiteness, by bringing them into dialogue with 'other' identities" (xxviii). Samantha Vice, on the other hand, has pleaded for a silencing and withdrawal of the white subject from the country's public discourse, a

\footnotetext{
${ }^{48}$ For a concise, general overview of the management of madness in the colonies see Pietikainen 97-103; see Keller; Mouralis; and Sow for 'colonial madness' in the African context. ${ }^{49}$ It should be noted that Veit-Wild's statement is not unproblematic as it seems to buttress European stereotypes about the African continent rather than overcoming them at first glance. Despite its seemingly Eurocentric character, however, the assertion nevertheless highlights the immediacy of the '(post)colonial condition' and its mad(dening) effects on the (post)colonial subject which, according to Veit-Wild, is bound to find (a more creative) expression in literature.

50 See e.g. Steyn; de Kock, "Blanc de Blanc" and "The Call"; Schmidt and West; and Vice who work within the field of critical whiteness studies; but also, McKaiser, Run Racist and Haffajee who do not associate with and criticise liberal whiteness and the field of Critical Whiteness Studies.
} 
proposition that received mixed reactions. ${ }^{51}$ In his recent book, Run Racist Run, Eusebius McKaiser explores 'non-bloody' racism (as opposed to acts of racism that entail physical violence) in present-day South Africa and the white liberal's involvement in, and reaction to, such acts of 'non-bloody' racism. Assessing the country's overall socio-political situation since the demise of apartheid, he writes:

I am angry. I am fucking angry. I am angry about the profound levels of social injustice in our country that refuse to go away because, between politicians, corporates and many wilfully ignorant citizens, we refuse to see the moral stains of the society we live in. We often pretend we do [...] but the structures of our society remain monumentally unjust. (9-10)

This passage brings me back to the concept of madness, my principal analytical category for this chapter. McKaiser's anger about present-day South Africa's social injustices and the continuing importance of race and racism - as well as their disavowal - are mad and maddening in both semantic notions of the words established above. Acts of racism can thereby oscillate between overt and clandestine forms of expressions as revealed in the second epigraph to this chapter. Due to this continuing racial madness that McKaiser describes in his book, South Africa becomes a mad(dening) place. Madness, race (the shifting understanding of South African whiteness being my focus here), and place are thus inextricably linked and it is this interconnectedness that informs my analysis of these concepts' manifestations in Johan van Wyk's Man Bitch and K. Sello Duiker's Thirteen Cents.

In Johan van Wyk's Man Bitch, which is set in Durban's Point Road area around 2000, madness expresses a white South African liberal's failure to adjust to the country's shifting racial power-geometries. On the one hand, the protagonist's self-imposed exile to Durban's red-light district in Point Road and his interracial relationships with various prostitutes can be read as a form of white liberalism. On the other hand, the protagonist's relocation can be seen as a mad(dening) class suicide that 'disturbs' the prevalent social order. What seems to be a paradise of peaceful cohabitation across apartheid's former racial boundaries at first rapidly transforms into a living hell of mad(dening) proportions for the protagonist at the separation of relationship after relation-

\footnotetext{
51 Vice's article "How Do I Live in This Strange Place?" has indeed kindled a controversy in the South African media. While McKaiser (in "Confronting Whiteness"; a position he has revoked more recently in Run Racist Run 2-3, 95-109) and Swart, for example, favoured Vice's position, de Kock ("Capitalism”) and Mnxqitama criticised Vice's suggestion.
} 
ship. Characterised by an abandonment neurosis in the most Fanonian sense (Black Skin, White Masks), the various interracial relationships speak to the protagonist's dis-ease within, and dis-respect towards, the country's shifted/shifting racial relations. The protagonist's inability and unwillingness to overcome his white privilege and anxiety ultimately brand Durban's Point Road area, and by implication post-apartheid South Africa at large, as a mad(dening) place.

In K. Sello Duiker's Thirteen Cents, predominantly set in Cape Town's Sea Point and Green Point during early post-apartheid, madness has, as previously mentioned, a more constructive and imaginative function. The novel follows the street child and boy prostitute Azure, whose repeated, brutal physical and sexual exploitation transform Cape Town into a mad(dening) place. Particularly the coloured gangsters who run the streets of Sea Point and Green Point tantalise Azure by perpetuating apartheid's white heteronormativity with their 'playing white'. Azure thus flees to Table Mountain where he has a series of dreams and hallucinations. It is in this mad(dening) space that he is able to re-connect with his cultural heritage and mentally overcome Cape Town's racially biased and violent post-apartheid power-geometries by killing his tormentors and destroying Cape Town in an apocalyptic battle. Azure's madness thus becomes a space of freedom and re-enforcement of black subjectivity. 


\subsection{JOHAN VAN WYK'S MAN BITCH}

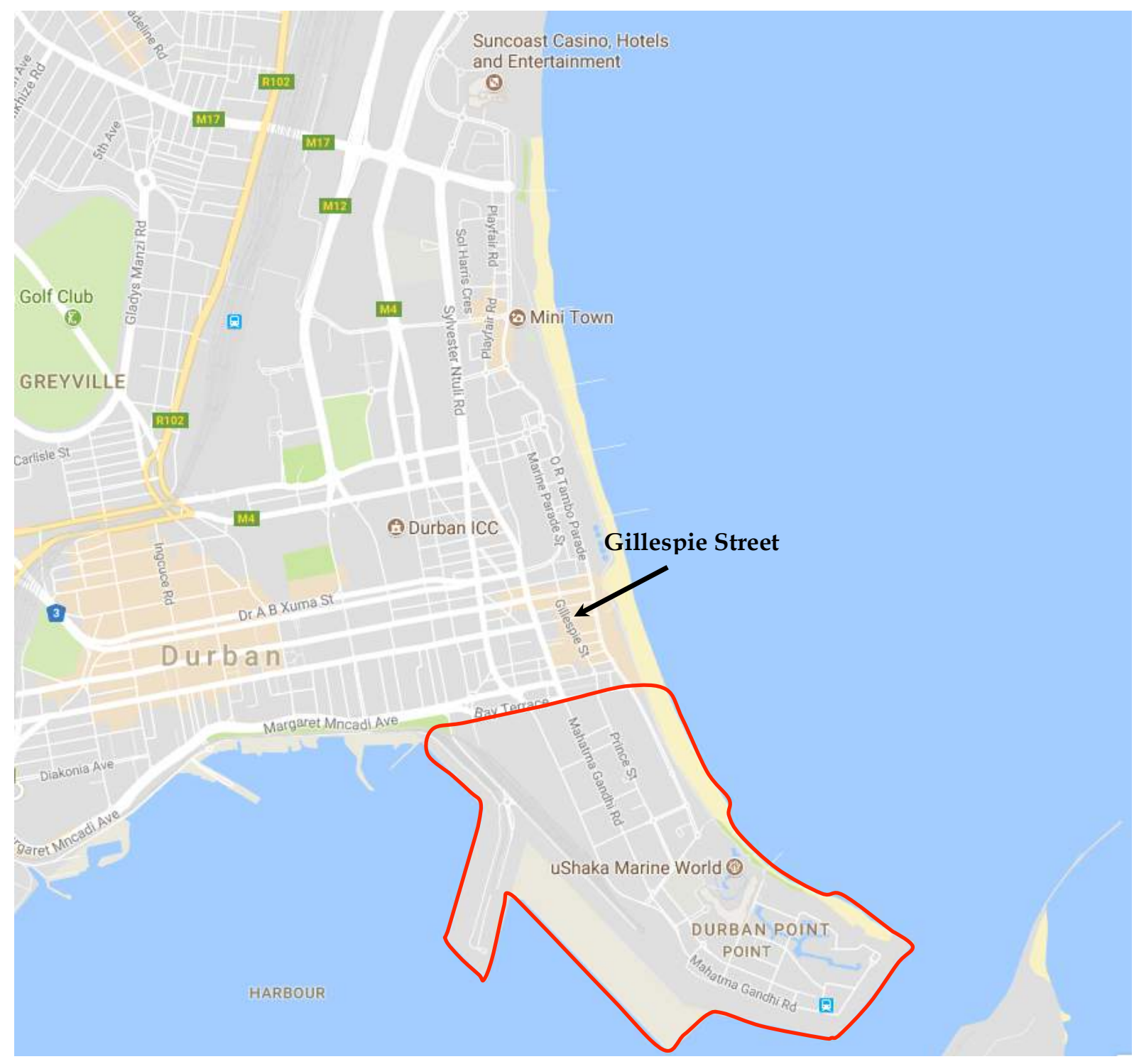

Figure 6: Map of Durban's (Greater) Point Area.

Gillespie Street runs between OR Tambo (old Marine) Parade and Mahatma Gandhi (old Point) Road. Together with Mahatma Gandhi Road, it forms, in a way, the frontcourt of the Point area, also referred to as the Point precinct. The latter is the headland south of Bay Terrace and Rutherford Street that forms the northern natural enclosure of Durban's harbour (see Figure 6). "Point Road", Barend van Niekerk writes, "around the turn of the century was Durban's most lively area and as late as the thirties it was Durban's version of Hamburg's Reeperbahn: nightclubs, hotels, cosy bars and all the paraphernalia belonging to the life of a sailor in port studded the streets" (114). With the Res- 
ervation of Separate Amenities Act of 1953, which sought to limit public contact between South Africa's different race groups by separating public facilities ("The History of Separate Development in South Africa"), Durban's beachfront, like those of other South African coastal cities, became racially segregated. Roughly, the beaches north of Battery Beach, today architecturally characterised by the Suncoast Casino complex (see Figure 6), were designated for non-whites, while the whole area south of it was reserved for whites. This included the lower part of Battery Beach, Snake Park Beach, and the whole of North and South Beach. The upper part of Battery Beach became a multiracial beach in 1982 and served as a 'buffer zone' between Durban's white and nonwhite beachgoers (Misgun and Oakes 120; see also Durrheim and Dixon, as well as Moller and Schlemmer).

With the segregation of the beaches, the area around Gillespie Street behind Durban's 'Golden Mile' became predominantly white, too. Awaiting death by hanging in prison for supposedly having raped a white girl, Ndi Sibiya, the protagonist of Lewis Nkosi's Mating Birds, reminisces:

I can see it all quite clearly: the beach, the children's playgrounds, the seafront hotels, and the sweating, pink-faced tourists from upcountry; the best time of all is that silent, torpid hour of noon when the beach suddenly becomes deserted and, driven back to the seafront restaurants and the temporary shelter of their hotel rooms, crowds of sea bathers suddenly vanish, leaving behind them not only the half-demolished cheese and tomato sandwiches but sometimes an occasional wristwatch, an expensive ring, or a finely embroidered handkerchief still smudged with lipstick from a pair of anonymous lips. Not infrequently, the tourists leave behind them an even worthier trophy - a young body lying spent and motionless on the warm white sands to be gazed at by us, the silent forbidden crowds of non-white boys in a black, mutinous rage. (2-3)

By the late 1970s, however, the Point area was "but a pale and really miserable reflection of its heyday as entertainment and commercial focal point in the first three decades of [the twentieth century]" (B. van Niekerk 48) and has further deteriorated since, despite existing plans to revitalise and upgrade the site that date back to the early 1990s (West). The deterioration is mainly due to the fact that the land in the Point area is owned by a handful of investors who are reluctant to rent out their buildings in anticipation of making high profits by selling their properties to big developers (Dardagan). Many of the buildings have been left vacant for years and are consequently in various stages of decay. "The plan for the Point was", Chris Kirby writes, "to transform the un- 
derutilised site into a major tourism and economic hub, in an attempt to regain national and international investor confidence", but the project "has yet to live up to the high expectations" (5). One of the realised subprojects of the Point area's revitalisation is the uShaka Marine World that opened its doors in April 2004. This recreational facility contains a water park, an aquarium, as well as a whole number of restaurants and shops (uShaka Marine World). Prior to the 2010 FIFA World Cup, the beachfront promenade, running between the uShaka Marine World and the Moses Mabhida Stadium, received a 'facelift' and now shines in new splendour. Furthermore, a number of residential and mixed-use buildings have been built south of the uShaka Marine World. Other than that, "the southern section of the Point, which has be[en] allocated for major development, remains relatively barren. There are large parcels of open land, as well as a series of old derelict buildings which are scattered amongst the new buildings" (Kirby 29). The northern part of the Point area remains largely unchanged.

The stagnation in the area's revitalisation is partly due to fact that the redevelopment plans had to be reworked several times (see e.g. Dardagan; Carnie; West). Investment in the area, however, spiked in 2015 due to the city's release of the new redevelopment plan for the Point precinct and the relocation of several big companies to the area (Dardagan). The latest redevelopment plan envisages an addition to Durban's skyline by erecting a row of skyscrapers along the beachfront south of the uShaka Marine World from the base of Vetch's Pier to the harbour (Carnie).

Another reason for the area's slow redevelopment is the Point's pervasive bad reputation. In 1979, Barend van Niekerk was already writing that the Point area was "regarded in a rather bad light and endowed with many unsavoury associations" (114). The area's negative stigma continues to exist more than thirty years later. In 2012, Neil Sungeeth, the manager at Durban Point Waterfront Properties, said that " $[t]$ he area you have to drive through to get to the Point precinct and uShaka is quite dilapidated. It is an eyesore as you travel down Mahatma Gandhi Road... The buildings need to either be refurbished or taken down completely." Sungeeth continues: "There is a feeling that it is not really safe to walk around outside the Point precinct, that there is an element of crime. And even if this is not so, crime should not be encouraged by having the buildings as they are. Development is happening very, very slowly" (qtd. in Fourie). 
In April 2015, Durban's Point area hit the headlines due to a wave of xenophobic violence that spread from the city's townships to the CBD. ${ }^{2}$ The Mercury reported that the foreigners built a barricade and armed themselves in protection against the locals effectively bringing Mahatma Gandhi Road to a standstill (Manda et al.). In addition, there is the greater Point area's notorious reputation as Durban's hazardous red-light district and drug hub. "With an estimated turnover of more than R1,4-billion", Jani Meyer writes, "Durban's notorious Point area has the dubious distinction of having a drug industry worth half the agricultural production of the entire province". In his review of Man Bitch, Lewis Nkosi, who knew the area, describes the inhabitants of the post-apartheid Gillespie Street and Point area as "the newly 'liberated' underclass of disappointed school-leavers, unemployed domestic and 'sex workers', or just spivs and drug dealers". Nkosi continues that "[a]ll of them are crowded into the waterfront where only a little over a decade ago they would have been rounded up and thrown into jail for 'loitering without an intent'. This human flotsam of bag snitchers, sex workers and dope peddlers of Gillespie Street represent the underside of post-apartheid society" (in Stiebel and Steffen 226). 53

Johan van Wyk (b. 1956) was born and raised in Welkom, a small mining town in Orange Free State (Lessing 45; "Johan van Wyk"), and spent his youth in Harare, Zimbabwe, and Mozambique (van Wyk, "Man-bitch: Poetry" 397; Kleinboer 30). In the 1970s he managed to evade conscription by escaping to Swaziland (Kleinboer 30). Van Wyk was, however, captured and detained until he was eventually discharged from the army on grounds of schizophrenia (van Wyk, "Man-bitch: Poetry" 397-398; Kleinboer 30). He received his MA in Languages and Art History at the University of the Witwatersrand and the University of South Africa and holds a PhD from Rhodes University. His doctoral thesis on the life and work of the Afrikaans poet Ingrid Jonker, which was supervised by the late André P. Brink, is entitled “Die Dood, die Minnaar

\footnotetext{
52 This new wave of xenophobia was reminiscent of the violent clashes in Soweto in January 2015 and the xenophobic wave of violence that started in Alexandra and spread to other townships of Johannesburg in 2008 (D. Smith; on the 2008 xenophobic attacks see e.g. Landau).

53 The review was published in the Neue Zürcher Zeitung on 27 July 2002 and is a shortened version of an unpublished essays by Nkosi, entitled "The World of Johan van Wyk", written in 2001. A reprint of the original newspaper article and an English translation, which I will be referring to in what follows, can be found in Stiebel and Steffen (219-227).
} 
en die Oedipale Struktuur in die Ingrid Jonker-Teks". ${ }^{54}$ He then became professor at the Centre for the Study of Southern African Literature and Languages (CSSALL) at the University of Durban-Westville (now University of KwaZulu-Natal) where he did pioneering interdisciplinary research in postapartheid and postcolonial studies ("Johan van Wyk"; Kleinboer 30). ${ }^{55}$

Van Wyk is well-known for his poetry collections which have established him as "a cult figure and icon" of Afrikaans poetry (Kleinboer 30; my translation). ${ }^{56}$ Man Bitch is van Wyk's first work of prose, or rather autofiction, ${ }^{57}$ in English. The language change, van Wyk said in an interview with Carel Lessing, was prompted by the poor reception and sales of his fourth poetry collection, which left van Wyk with little Afrikaans in him (45).

Man Bitch was self-published in 2001 after several publishers had rejected the manuscript (van Wyk, "Man-bitch: Poetry" 403). The partly autobiographical, partly fictional(ised) account is an unapologetic chronicle of the sexual encounters and failing/failed relationships between the first-person narrator, who bears the same name as the author, and seven black prostitutes. What seems to be the midlife crisis of a white, middle-aged university professor at first glance, at the same time turns out to be an unrelenting depiction "of a slice of life lived in the demi-monde of Durban's port and beachfront area, set

54 "Death, the Lover and the Oedipal Structure in Ingrid Jonker's Work." Van Wyk selfpublished his PhD in 1999 under the title Gesig van die Liefde: Ingrid Jonker (The Face of Love: Ingrid Jonker; my translations).

55 Among his academic publications from his time at the CSSALL are his book Constructs of Identity and Difference in South African Literature and the co-edited volume Rethinking South African Literary History (together with Johannes A. Smit and Jean-Philippe Wade).

56 Van Wyk's poetry collections are: Deur die Oog van die Luiperd (Through the Eye of the Leopard); Heldedade Kom Nie Dikwels Voor Nie (Heroic Deeds Are Rare); Bome Gaan Dood om Jou (Trees Die Around You) and Oe in ' $n$ Kas (Eyes in a Case; my translations).

57 There is a whole range of genre labels that have been used in relation to Man Bitch (see Kleinboer; Lessing; N. McNulty, "Reading the City"; Nkosi, "Freiheit" and "The World"; Reddy; Stiebel, "Lewis Nkosi's Durban"; Visagie, "Wit Mans"). Personally, I will follow Visagie's suggestion and refer to Man Bitch as an autofictional novel or, in view of the text's conciseness, rather as an autofictional novella. Despite the nominal conflation of author, narrator, and protagonist that the label 'autofictional' accounts for, it nevertheless places a strong focus on the text's fictional(ised) component. The label thus accommodates my caution with regard to reading the text as (mainly) autobiographical. Van Wyk did not label the book as autobiographical. Niall McNulty furthermore rightly points out that "[f]or a supposed autobiography, we learn very little about Johan van Wyk, the man" ("Reading the City" 42). All the (implied) reader learns about the protagonist is his profession, his place of residence, his predilection for young, black prostitutes, and (partly, but not only, because of his interracial relationships) that he has a(n) (e)strange(d) relationship with his conservative parents. To be fair, this is partly due to the fact that the text has a limited timeframe, i.e. the turn of the last millennium, and thus has to be seen as a snapshot of a particular (space-)time and not as a full-fleshed autobiography. Man Bitch is, to quote McNulty again, "more a biography of a place and a time than a man" (45). 
one or two blocks back from the 'Golden Mile' of the tourist strip" (Stiebel, "Lewis Nkosi's Durban" 234). Van Wyk's Gillespie Street is, according to Nkosi, "a horizontal hell without depth but a great deal of surface" (in Stiebel and Steffen 224).

Man Bitch is based on notes van Wyk took over a period of three years while he was living in Gillespie Street (Lessing 45). Extracts of these notes were published as a series of blog posts called Gillespiestraat-slenters (i.e. Gillespie-Street-Scams) on LitNet, an independent Afrikaans literary journal on the Internet, between January 1999 and April 2001 ("Gillespiestraat-slenters"). In 2000, van Wyk recorded an abridged version of the text in preparation for readings in England and Poland. The CD, entitled My Name Is Angel but I'm Not from Heaven in Any Way, 58 was distributed by Ike's Bookshop in Durban and the author himself (van Wyk, "Man-bitch: Poetry" 401). A second, shortened and revised edition of Man Bitch, which will be the basis for my analysis, was published in 2006, again at van Wyk's own expense.

Despite the commotion that Man Bitch caused upon its publication, ${ }^{59}$ van Wyk's novella has received little scholarly attention. It is, however, surprising that, notwithstanding the text's generally sinister, disturbing, and explicit character, the few existing readings of Man Bitch are positive (N. McNulty "Reading the City"; Nkosi "Freiheit" and "The World"; Visagie, "Wit Mans"). Lewis Nkosi argues that Man Bitch "reveals that the effacement of lines that once divided city inhabitants according to race or ethnic origins in turn permits the emergence of new characters in fiction who use the newly deployed space to express new identities" ("The World" 4). According to Nkosi, the novella's protagonist "figures mainly as the 'victim' of the street-wise black women who driven by personal need, greed or pure malevolence, take their revenge on a well-intentioned member of what was once a powerful white tribe in South Africa" (9). Niall McNulty similarly argues that the area, despite its notorious reputation, provides a home to the novella's characters and that Durban's inner-city "is also shown to be a cosmopolitan melting place of the old and the new, of different cultures and belief systems and of people across the race and economic divide" ("Reading the City" 71). Despite taking into account the more negative aspects of van Wyk's novella, Andries Visagie, akin to Nkosi and McNulty, argues that Man Bitch gives expression to new, "more porous" forms of South African identities which "are based on a rapproche-

58 This is the answer given by Angel, one of the prostitutes the narrator meets and has a relationship with, when asked for her name (van Wyk, Man Bitch 9).

59 See Kleinboer 30; Nkosi, “The World" 10; Reddy 12; van Wyk, "Man-bitch: Poetry" 404. 
ment to and identification with the historical other of white people in Africa, namely blacks and more specifically black women". At the same time, according to Visagie, "[t]here is also a recognition [...] that these identities are to be born out of the dirt of hundreds of years of sexual - and racial [-] inequality in South Africa, a birth that must take place in liminal spaces such as Durban's Point area $[\ldots]$ where cultural reciprocity and hybridisation have become essential survival strategies [...]" (“Wit Mans" 245; my translation).

The self-imposed - and at the same time mad(dening) - marginalisation of Johan van Wyk, the narrator and protagonist of Man Bitch, ${ }^{60}$ may have a hopeful and optimistic incentive to start with, however, the predominantly positive lens through which the novella has been read so far shies away from the more uncomfortable, socio-political post-apartheid 'realities' the text depicts. Reading the novella in terms of South Africa's whiteness debate allows the unearthing of extant and deeply rooted, $\operatorname{mad}($ dening) questions of race which speak to the protagonist's white privilege and his anxiety of being left behind in the new South Africa. I argue that while van Wyk may be acting in good faith at first, his abandonment neurosis (Fanon, Black Skin, White Masks) becomes paramount for his inability and unwillingness to defeat his racial preconceptions, an inability that, in turn, has a mad(dening) effect on him. Such a psycho-social reading reveals a seemingly insurmountable catch-22 situation at the centre of van Wyk's interracial relationships. The increasing (mental and physical) dis-ease the protagonist displays throughout the novella is thereby not only indicative of the protagonist's narcissistic (self-)victimisation but also becomes a powerful metonymy for the ailing/ailed body politics of post-apartheid Durban in particular and post-apartheid South Africa more generally. While Man Bitch is a deeply problematic piece of autofiction, it is the novella's problematic nature, particularly with regards to its treatment of race and gender, that confronts a number of socio-political and -economic issues far ahead of its time.

\section{Romantic Durban/Devilish Durban: The Point ARea in MAN BITCH}

Johan van Wyk's decision of a life in Durban's red-light district is mad(dening) in two respects. It seems incredibly reckless - paramount to so${ }^{60}$ Unless indicated, when I talk about Johan van Wyk, I henceforth mean the novella's narra-
tor and protagonist and not the author. 
cial suicide - for a white, middle-aged university professor to go and live in such a 'disreputable' neighbourhood of Durban's CBD in order to entertain relationships with various black prostitutes. It seems even more insane to romanticise life in Durban's drug hub and love mile considering the harsh everyday realities of most of its inhabitants, particularly the various prostitutes with which van Wyk is involved. While the former can be seen as a conscious break with social expectations, the latter speaks to, as I will argue in what follows, the protagonist's white privilege, which is inextricably linked to aspects of walking and movement. Van Wyk's choice is partially explicable by the new freedoms that came with the 'spatial openness' of post-apartheid South Africa. As 'racial mixing' was no longer a crime as it was under apartheid, the country entered a space-time of hope and great expectations after the first democratic elections in 1994. In this respect, Carol Long, in her article "Transitioning Racialised Spaces", argues that "[t]ransitional phenomena [...] are areas of creativity where distinct divisions between self and other and playing and reality are suspended in potential space" (62). It is this "transitional spacetime' that 'allows' van Wyk's madness and justifies Niall McNulty's, Nkosi's, and Visagie's more positive readings of the novella outlined above. ${ }^{61}$

The city's hilly topography, heavy traffic, and busy CBD do not make Durban a pedestrian-friendly city. Its beachfront promenade and beautiful, long stretches of beaches are the exception. It is through his walking the Point area's streets that van Wyk (re-)maps his surroundings:

I went for a walk at seven in the morning. Durban was waking up and outside Costa's I saw the owner carrying tables outside. I walked all along the promenade next to the sea. A few people jogged, while others were fishing on the pier, extending into the greenness of a misty horizon.

At the flea market, I turned around, and walked back. The sellers, hoping it was not going to rain, were still unpacking their goods. I passed two Jehovah Witnesses, preying on the lonely, while Zulu aunties were arranging their curios and beads along the sidewalk. From a transistor came the nostalgic sounds of

\footnotetext{
61 In his article on Zakes Mda's novel Ways of Dying, van Wyk argues that transitional spacetimes are accompanied by the production of transitional literature. This literature, according to van Wyk, can be characterised as follows: "A resurgence of repressed instincts embodied in images of violent death, birth and sexuality, accompanies the breakdown of the old order. This resurgence of the repressed in turn implies regression: a loss to some extent of the reality principle (so that the form of this literature evokes the dream and mysticism). Death combines with rebirth, and the apocalyptic with the carnivalesque" ("Catastrophe and Beauty" 80). Many of these characteristics are indeed present in Man Bitch. This theoretical contextualisation helps in understanding N. McNulty's, Nkosi's, and Visagie's reading of the novella as a distinctly transitional piece of (auto)fiction.
} 
the Staccatos singing, 'Cry to Me'. Back in West Street, the shop owners were unlocking their shops.

An old pale man with a plastic red nose, who usually played the penny whistle at the entrance of Oxford House, sat despondently with his head on his arms, while the blind man on the steps of the Wheel shook his tin furiously. He has no eyes to intimidate the passers-by with. Three Quarters sat on a cement block, his wooden leg stretched out in front of him. He peered into nothingness, with his oily locks and sunburnt face.

Rugged men and a girl sat outside at a sidewalk table at Costa do Sol. Inside there was soccer on the TV, and great applause and jubilation. I returned to my flat. (van Wyk, Man Bitch 2)

Van Wyk's incessant walking evokes the figure of the flâneur, as McNulty argues ("Reading the City" 53-58). Interestingly, and this has gone unnoticed so far, van Wyk exhibits both elements of the Baudelairean notion of flânerie as well as its Benjaminian counterpart or continuation thereof. It is the former, more 'romantic' type of flânerie that prevails in the passage above. Baudelairean flânerie, Keith Tester argues, "call[s] forth a poetic - and a poet's - vision of the public places and spaces" (1).

In Man Bitch, van Wyk's (initial) vision is one of a 'poetic re-union'. His early morning stroll establishes an elated atmosphere with the joggers and fishermen along the promenade as well as the "Zulu aunties" setting up their stalls and the various shop owners opening their shops for the day (van Wyk, Man Bitch 2). At the same time, the walk stakes out the principle setting for the greater part of the novella and introduces two of its most important places: 27 Oxford House in Gillespie Street, van Wyk's home-place, and Costa do Sol, the narrator's favourite bar in the neighbourhood where he drinks and meets (his) girls (see Figures 7 and 8). While the homeless people, who complete van Wyk's early-morning picture of Durban, certainly emphasise the area's ambiguity, they do no harm to the generally positive atmosphere of the excerpt. On the contrary, they seem to complete the picture of a peaceful, multicultural cohabitation and/or coexistence in, and around, the greater Point area. 


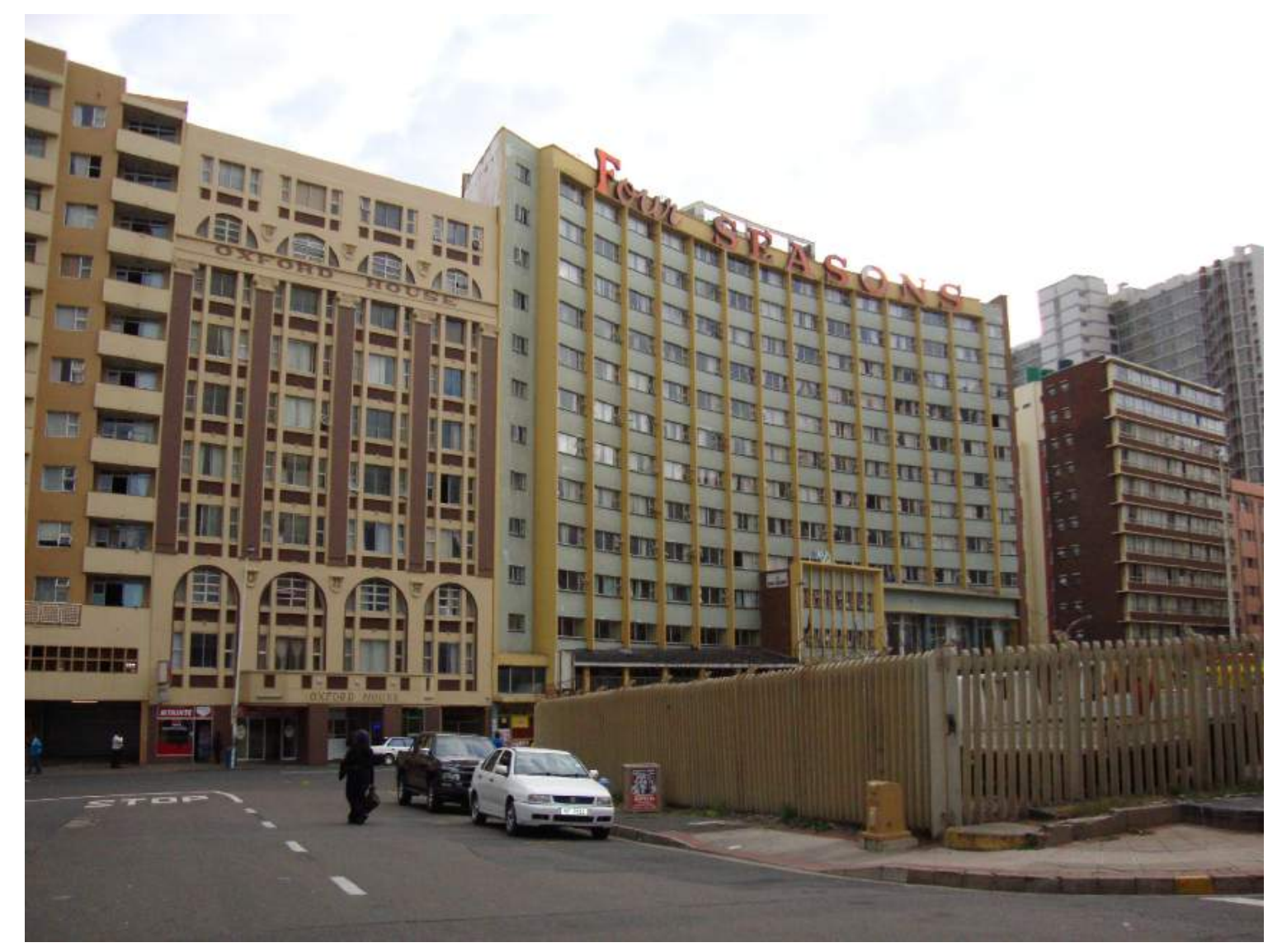

Figure 7: Oxford House and Four Seasons Hotel in Gillespie Street.

Durban's inner-city, which the greater Point area and the beachfront are part of, is indeed portrayed as "a site for the clash of subcultures", as McNulty suggests ("Reading the City" 56). Sporting events, such as the soccer game the customers of Costa do Sol are following with "great applause and jubilation" in the excerpt quoted above (van Wyk, Man Bitch 2), highlight the area as a multicultural point of intersection. One night, the protagonist similarly reports that he "ventured into the streets. There was great activity and excitement: Bafana Bafana won against Mauritius, and the South African cricket team against Pakistan. Costa do Sol were [sic] full of people celebrating the victories" (5). The two sports jointly celebrated here are typically black and white sports, respectively (N. McNulty, "Reading the City" 56). If one considers the strict racial segregation that was in place within the domain of sports during apartheid, their joint celebration becomes an even more powerful symbol for 'racial unison'. While after the demise of apartheid a quota system was introduced to redress racial inequalities within the national teams of the various sports popular in South Africa, Costa do Sol - and by implication the greater Point area - is furnished with a 'romantic(ised) role model function' that accounts for the non-racialist ideals of the 'rainbow nation' without the need for 
legal regulations to overcome racial boundaries. At a later point, the "streets were full of high-school kids in tracksuits. Durban was the host of some big sporting event" (van Wyk, Man Bitch 11). The high-school kids may not match the area's 'dubious', lower-class image and may reflect the area's contrasting character (N. McNulty, "Reading the City" 56), but the sporting event also draws people into an area they would usually not necessarily frequent and can thus again be seen as a symbolic 'break-down' of social boundaries. Music serves a similarly 'unifying' purpose. At one point the protagonist tells the (implied) reader about the Four Seasons Hotel just next to his block of flats having "a motorcycle gang congregat[ing] there: guys and girls trying to see who could make the most noise, some of the girls singing a beautiful Negro spiritual, while their boyfriends gave it a kwaito-chorus" (van Wyk, Man Bitch 4). McNulty pointedly observes that the motorcycle gang is a "typically white subculture" ("Reading the City" 56). The stereotypical association of such gangs with (hard) rock and/or heavy metal music is dismantled through their performing a musical mix of an African-American slave song with kwaito. Kwaito music, according to Bhekizizwe Peterson, is "undoubtedly the most singular innovation in popular culture in South Africa in the 1990s" and is characterised by its musically 'hybrid' form that draws from a wide range of local and international music styles including "South African 'bubble-gum', rap, reggae, ragga, rhythm and blues, as well as European and American house-music" (198). Its language is the so-called "scamto", an urban slang that mixes African languages with English and Afrikaans (199). The hybrid character of kwaito music thus once again serves to highlight the neighbourhood's racially and socially mixed character.

All these examples establish the greater Point area as a distinctly open place and emphasise the protagonist's cross- and inter-cultural vision thereof. Van Wyk's flânerie stands, however, in stark contrast to the various prostitutes' socio-economic options and becomes emblematic of his white privilege. This becomes particularly evident in the following passage which describes van Wyk's trip to one of Durban's beaches with Angel and Poschia, two of the prostitutes he frequents: 


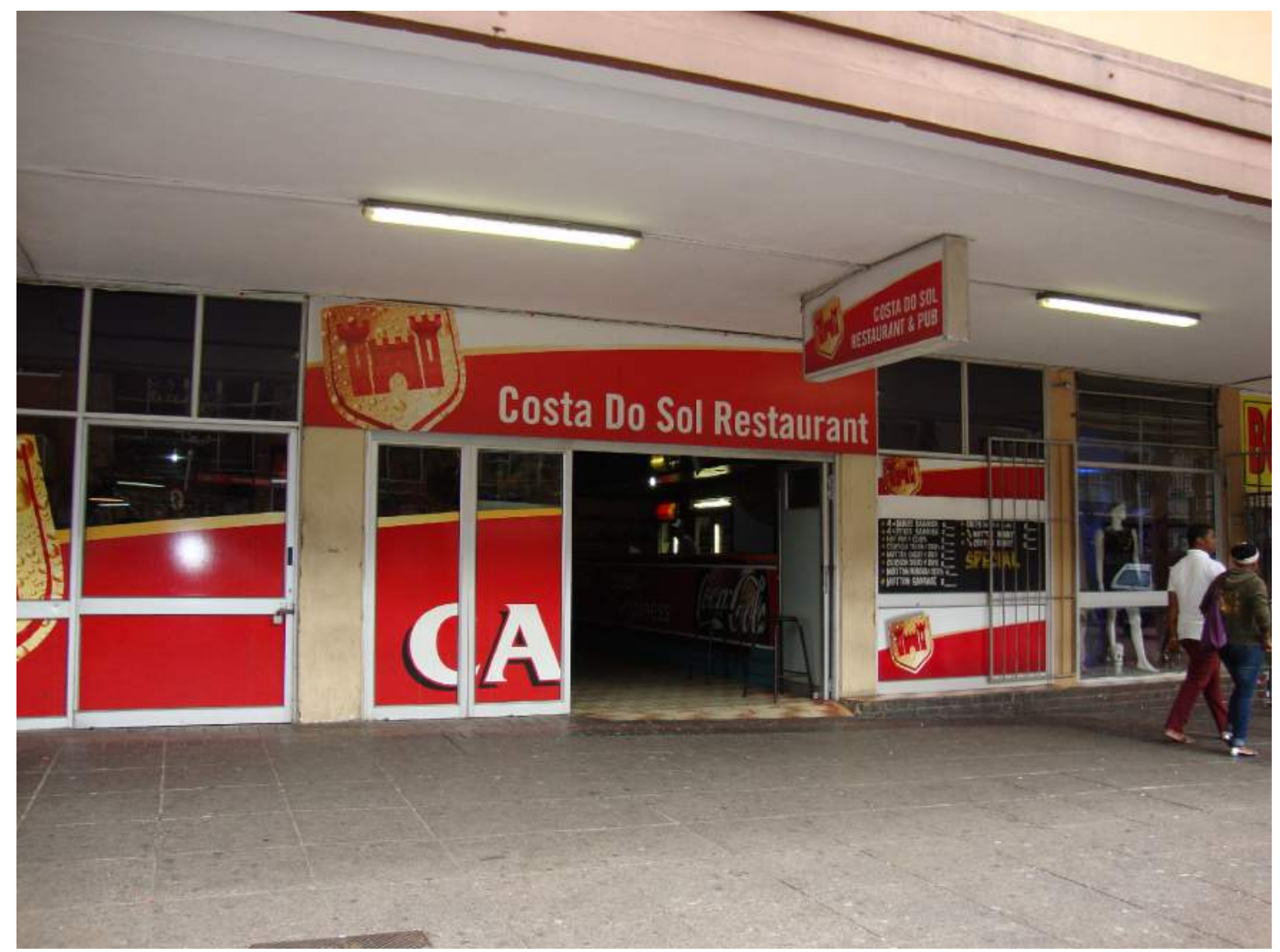

Figure 8: Costa Do Sol Bar in Dr Pixley Kaseme Street.

We took the Maydon Wharf road, at the back of the harbor, through the Bluff, where I knew a secluded beach at the end of Sloan Street. It was low water, with rocks appearing everywhere above the foam of the withdrawing waves. We walked until we found a space where it was not too rocky, and we could swim. Unlike Durban, the sea was alive here, with shells washed up on the beach, and the remains of crabs, lobsters, and oysters. The water was surprisingly warm. The rock shapes, resembling sharks and octopuses, appearing every now and again just above the swirling water, frightening Angel and Poschia. Then we saw a small fish, trapped by the low tide, and I caught it with my hands, and we put it in a plastic Coke bottle with a big hole on the side. (van Wyk, Man Bitch 13-14)

While the outing is depicted as a memorable event, at least from van Wyk's perspective through which the whole experience is necessarily focalised, it establishes a clear socio-economic demarcation between the narrator and his companions. Since the beach is only reachable by car, Angel and Poschia (themselves not in possession of a car) are generally excluded from these recreational spaces within the city. The women's spatial restriction is further stressed by the narrator's observation of the rich marine life that is in opposi- 
tion to Durban's 'dead' sea. This life/death-dichotomy pre-empts van Wyk's increasingly purgatorial experience and depiction of the Point Road area and establishes the women as part of a 'lifeless' city-space that deprives them of a privacy in service of their clients' (sexual) pleasure. While the sea has a purely recreational function for van Wyk, its function is thus more ambiguous for Angel and Poschia. The sea supplies them with "a mixed crowd of Oriental and East European seaman" (15), their sources of livelihood which, similarly to the "crabs, lobsters, and oysters" in the passage above (14), are "washed ashore' at Durban's harbour. At the same time, the sea demarcates a physical boundary for Angel and Poschia that they are not likely to overcome since their socio-economic restraints prevent them from travelling the world, much unlike van Wyk who, throughout the novel, travels extensively. Lewis Nkosi, reminiscing about Durban's ship traffic and commenting on the prostitutes' situation in Man Bitch writes: "Now the passenger lines are gone but the merchant ships still enter and leave the harbour in a way no less provoking to wanderlust than when I was a young boy, but those who watch the sea now cannot leave the country just as they wish for lack of financial means" (in Stiebel and Steffen 226). The "small fish" the narrator catches "with [his] hands" and then 'showcases' in "a plastic Coke bottle" in the above-quoted passage (van Wyk, Man Bitch 14) thus become symbolic both for the prostitutes' 'imprisonment', i.e. their socio-economic restrictions, and their sexual exploitation at the hand of van Wyk and other clients. The prostitutes' fate is very similar to Ndi Sibiya's in Mating Birds. Ndi Sibiya is also black and poor and exploited by Veronica before being left out to hang in the most literal sense.

The romantic(ised) stance at the bottom of the leisurely outing is typical for the Baudelairean flâneur whose perception is a selective one at best. Benjamin, who has extensively commented on Baudelaire's work, argues that the Baudelairean flâneur has:

the gaze of [an] alienated man [...] whose way of living still bestowed a conciliatory gleam over the growing destitution of man in the great city. The flâneur still stood at the margin, of the great city as of the bourgeois class. Neither of them had yet overwhelmed him. In neither of them was he at home. He sought asylum in the crowd. [...] The crowd was the veil from behind which the familiar city as phantasmagoria beckoned to the flâneur. In it, the city was now landscape, now a room. (Charles Baudelaire 170; original emphasis) 
According to Benjamin, the flâneur is 'out of tune' with the city. He has not yet, or not really, 'caught up' with its changing/changed 'face' of his surroundings. Socially marked by a downward movement and at the same time both part of and separate from the crowd in which he seeks refuge, the flâneur is characterised by a double, self-imposed marginalisation that renders him essentially 'homeless' (see also Frisby 87). It is his 'alienated gaze', I would argue, that makes the flâneur a mad(dening) figure since his marginal position within society can be seen as a mad(dening) alienation from his 'true' self as well as his (original) social environment (Pietikainen 107). In addition to van Wyk's alienation by moving to the Point and thus (seemingly) relinquishing his white middle-class background, his 'phantasmagorical' vision of the city, which changes its meaning according to the narrator's needs and safeguards (or perpetuates) his 'belonging separateness', further adds to his mad(dening), i.e. eccentric, character.

This fundamental oxymoronic characteristic of the flâneur's position within the city and its social fabric finds varied expressions throughout Man Bitch. On his way to visit his first girlfriend Mbali, who is hospitalised at King Edward VIII Hospital in Durban with advanced symptoms of HIV/AIDS, van Wyk recounts how "[a] large crowd gathered at the entrance. Apart from a housewife and her daughter, I was the only white in the crowd. At one o'clock the crowd, consisting of families dressed up in their Sunday clothes, with plastic bags and food, started to move through the gates" (van Wyk, Man Bitch 6). A similar situation arises later on when van Wyk goes for a walk along the beachfront with the children of his then girlfriend, Luisa from Mozambique, realising that "[e]verybody stared at the white man, strolling with black toddlers" (26-27). Both examples highlight the 'markedness' of van Wyk's existence and by implication that of the flâneur. Within the Point area, which has seen a great influx of blacks (both South African and foreign) since the demise of apartheid as seen above, the (white) narrator is the 'odd one out'. The first incident may not be concerned with walking per se but it clearly establishes van Wyk as both part of the crowd and at the same time standing out of it due to his skin colour. The second example elaborates on his 'belonging separateness'. Similar to the incident at the hospital, van Wyk, here together with Luisa's children, is part of the crowd, but the other walkers' 'racialised' gazes at the same time separate him (and the children) from it. It is van Wyk's markedness, I would argue, that signifies a break away from Baudelaire's romantic(ised) 'original' figure. Such a markedness may be predictable and inevitable within the post-apartheid context. It is, however, in this predictability and 
inevitability, which seem to go unnoticed on van Wyk's part, that the dilemma of his flâneuristic existence lies.

The protagonist, for example, does not comment on the stares of the passers-by but merely acknowledges them and when asked about the children, he claims them as his:

A student came up to me: 'Hi, Prof, are they yours?'

'Yes.'

'Where is the mother?'

'At the flat.'

A grandmother asked: 'Baba, are they all yours?'

'Yes, mamma,' I said. (27)

There are two sides to the coin here. The scene, at first glance, speaks to the narrator's non-racialist attitude that clashes with the general public's rootedness in a long-established 'zebra thinking'. Portraying himself as 'ahead of his time', van Wyk attempts to break with the romantic(ised) Baudelairean flâneur who, according to Benjamin, suffers from a spatio-temporal belatedness rather than a foresightedness (Charles Baudelaire 170). This progressive self-portrayal, however, at the same time reiterates the romanticising that lies at the heart of Baudelaire's 'poetic flânerie'. By merely acknowledging the passers-by and their stares, van Wyk consciously chooses to ignore the continuing importance of race within the post-apartheid context. This deliberate disavowal can be seen as an indicator of the narrator's disavowal of racial matters within postapartheid society, a 'luxury' of the white liberal who, according to McKaiser, can afford 'racial blindness' (Run Racist 18). Melissa Steyn who, in her book on South African whiteness, discusses different "shades of whiteness" by presenting five "narratives of whiteness" (47-148), calls this variation of whiteness "A Whiter Shade of White" (101-104). It seeks "to establish racial innocence" and, according to Steyn, "[t]here are obvious, self-serving reasons why it should suit whites in South Africa to be colorblind now that the politics in the country have changed. This is a tale of evasion" (153). Van Wyk's claiming the children to be his, however, can furthermore be seen as an act of 'appropriation' and 'self-exoticising' in an attempt to belong to the Point's black community. Steyn labels this understanding of whiteness "Don't Wanna be White No More" (120-127). This form of dealing with and expressing whiteness seeks "a public overidentification with everything that is black" and is, Steyn argues, "an attempt to evade the pain of confronting whiteness, by appropriating blackness. People who are deeply identified with white guilt tell this tale" (121, 154; orig- 
inal emphasis). One form of dealing with this guilt is by "taking on a pastiche of blackness" (154) such as is the case with van Wyk's (public) appropriation of Luisa's children to 'make himself black(er)'. This appropriation of blackness on van Wyk's part becomes even more evident through his various interracial relationships. The "pastiche of blackness" that is achieved by the protagonist's relationship with the different black prostitutes, however, goes beyond a mere transgression of former racial taboos, as both Niall McNulty ("Reading the City" 67) and Visagie ("Wit Mans" 243) suggest. It also speaks to the complex processes of white subjectivity formation within the post-apartheid context at play here, a connection that I will discuss in the next section. Ultimately, van Wyk's 'racial blindness', in combination with his 'self-exoticising', undermines his non-racialist values which have to be relativised and seen as part of his phantasmagorical world view.

The examples discussed so far not only lay bare the narrator's underlying racialised beliefs and white privilege, but also put to the forefront his search for a sense of belonging within South Africa's post-apartheid society. "The changes in the country", Steyn posits, "have suddenly made whites feel 'out of place.' [...] There is an acute sense of loss of the familiar, loss of certainty, loss of comfort, loss of privilege, loss of well-known roles" (156). The white subject's sense of dis-placement and dis-comfort within South Africa's new dispensation, according to Steyn, is related to an "unfamiliar, even alien" sense of 'home' (157). Such an 'alienation' with regard to the sense of 'home' is perceptible in Man Bitch. Van Wyk's flat in Gillespie Street is not a very 'homely' place to begin with. The flat is a neglected place, "with dishes piling up, dust gathering on half-read books" (4) and it is a place of loneliness, which is - almost stereotypically - mirrored in the flat's emptiness $(1,9)$. The desolate state of van Wyk's flat can thus be seen as a reflection of the white South African's uncertain subject position. In an attempt to improve his flat's 'homeliness', van Wyk "fill[s] it with his girlfriends" (N. McNulty, "Reading the City" 59). As the different women 'revitalise' the narrator's home-place, new points of conflict arise and at times, the women seem to be just as annoying for van Wyk as the cockroaches which eventually "tak[e] over [his] space" so that he needs to initiate "an extermination campaign" (van Wyk, Man Bitch 50).

As the incongruence between the narrator's phantasmagorical perception of the Point area and the fictional(ised) 'real conditions' grows, his initially romantic(ised) depiction of the area becomes increasingly more sinister. About two thirds into the novella, van Wyk recounts that "there was lightning all around the skyscraper hotels" which he equals to "the physical image of hell" 
(50). When opening the window of his flat shortly thereafter, he remembers how "the breeze, the voices of an excited drunken crowd and sirens floated in" and associates the experience with "hear[ing] the sounds of hell" (50). With love turning into "a kind of hell" (58) and the protagonist's flat "becoming [his] hell" (70), the infernal eventually finds its way into van Wyk's private sphere. This increasing overlap or blurring of the public and the private sphere is reminiscent of Homi Bhabha's concept of the 'unhomely', which I discuss and use in connection to Bridget McNulty's Strange Nervous Laughter in Chapter 3.1. Bhabha conceives of the 'unhomely' to account for the postcolonial subject's essentially dis-placed position and the postcolonial subject's resulting unease within the postcolonial world. Considering that in Man Bitch the white subject is described as being unhomed and that this position is self-perceived, van Wyk's unhomed state can be seen as an expression of his growing white anxiety.

The series of (freak) accidents he records throughout the novella further add to the Point's infernal properties. There is, for example, "a truck that landed on a bakkie" (4). While a woman has to be freed from one of the vehicles, there are no fatalities. Shortly thereafter, "[a] slab of concrete fell and killed two people on the sidewalk outside the Squireman's Pub" (4). Later on, "a man was run over by a car on the fly-over. He must have been crazy, thinking that he could dash across the highway" (50). The floods that beset South(ern) Africa in late 1999/early 2000 similarly contribute to the Point's hellish picture where "cars washed down Gillespie Street" (47) as a result of the incessant rainfalls.

Nkosi pointedly observes that "[i]mages of hell, man-made or malignant acts of God, abound in Man Bitch" and he rightly adds the ever-present threat of HIV/AIDS, "South Africa's biggest killer disease", as another aspect of the Point area's infernal character ("The World" 12). The disease's omnipresence has not only a far-reaching societal impact but also a more personal, purgatorial 'what if-effect', both for the prostitutes as well as the narrator himself. "Angel said", van Wyk reports at one point, "that if ever she was told that she had AIDS, she would drink petrol, and set herself alight on the highway" (van Wyk, Man Bitch 61). Susan Sontag, in AIDS and its Metaphors, describes "[t]he end-of-the-world rhetoric that AIDS evoke[s]" and argues that the apocalyptic rhetoric around AIDS is a coping mechanism to handle seemingly 'uncontrollable fear' (174-175). In the South African context, that fear will necessarily be a racial(ised) one. 
In view of the numerous, more negative, (counter-)examples of the fictional(ised) life in the Point, van Wyk's initially romantic(ised) depiction of the area is, contrary to his flânerie and its generally phantasmagorical perception, replaced by an increasingly infernal picture thereof that could be labelled as 'dystopian' or even 'apocalyptic'. If taking this viewpoint, van Wyk's novella joins the ranks of a growing body of dystopian/apocalyptic works within the South African literary scene. Texts such as K. Sello Duiker's Thirteen Cents and Lauren Beukes' Moxyland, which will be discussed in the second half of this chapter and Chapter 3.2, respectively, or Charlie Human's Baxter Saga as well as Lily Herne's Mall Rats series come to mind here. ${ }^{62}$

Commenting on the significant growth of dystopian/apocalyptic texts within South Africa's literary scene since 2000, Michael Titlestad posits that this type of literature "stages itself as presenting a sobering rejoinder, if not an outright pessimistic counterpoint, to the story of the transfiguration of the nation from international pariah to moral beacon, now shining its light into the racist recesses of the world". Considering that the vast majority of the genre's texts are penned by white writers, South Africa's dystopian/apocalyptic literature, according to Titlestad, can not only be seen as representative of historically entrenched (socio-)political antagonisms but also as an addition to "the public conversation about racialized fear" (31). Christopher Thurman similarly claims that considering the racial disparity with regard to the writers who work within the genre, South African dystopian/apocalyptic literature "does indeed foreground, presuppose or underscore (implicitly or explicitly) whiteness" ("Apocalypse Whenever" 60). The novella's increasingly dystopian/apocalyptic tenor thus reflects the Point area's increasingly mad(dening) effect on the narrator and his growing white anxiety, both of which are inextricably linked to the fate of the repeatedly failing/failed relationships between van Wyk and the different black prostitutes. The novella's increasingly dystopian/apocalyptic tenor, is at the same time connected to the central theme of mental and physical dis-ease. Both aspects will be addressed in the remainder of the chapter, starting with the protagonist's interracial relationships.

62 While Human's Baxter Saga consists of Apocalypse Now Now and Kill Baxter, Lily Herne's Mall Rats series comprises Deadlands, Death of a Saint, The Army of the Lost, and Ash Remains. 


\section{THE ECONOMY OF LOVE FOR SALE}

The fact that the relationships between the narrator and the various black women fall apart leaves the (implied) reader wondering why the protagonist repeatedly engages in them. There have been different attempts at answering this question:

Visagie, on the one hand, reads the (sexual) relationships between van Wyk and the various black women as "a liberation from the taboos of [sexual] intimacy with the [black] other" which was impossible under apartheid's strict racial segregation. At the same time, he argues that this breach is linked to the narrator's implicit death wish, death being imminent in the danger of being infected by HIV/AIDS. Visagie suggests that the narrator's death drive could be seen as the motivation behind his continuous (sexual) involvement with the various women, an involvement that "threatens to overwhelm, even destroy, the culturally acquired contents of the [white] self" ("Wit Mans" 243; my translation). Despite the omnipresence of death, Visagie ultimately puts the (sexual) relationships into a positive light and - reading them as an interplay of the protagonist's Eros and Thanatos (Freud, "Beyond the Pleasure Principle") - sees them as a fictional(ised) expression of reciprocal and hybrid subjectivities that, according to him, are necessary in order to survive within the post-apartheid context of Durban's Point (245). There certainly is an idealistic intention of a non-racial coexistence at the heart of the different interracial relationships. Such a reading, however, neither accounts for the repeated failure of the relationships nor the inherently mad(dening) and self-destructive contradictions at play in these 'amorous liaisons'.

Niall McNulty, on the other hand, suggests considering the relationships either as the protagonist's "claim to the potential power of the space of the black female" or alternatively the protagonist's "rejection of his Afrikaner apartheid heritage" ("Reading the City" 67). While there is some truth to both of McNulty's suggestions, I would question van Wyk's success both in asserting his position within the (living) space of the various black women as well as the discarding of his Afrikaner background. In van Wyk's failure, however, lies the narrative's greatest potential, as it is through the constant power struggles and manipulations within the different (sexual) relationships that the narrative's social criticism becomes most visible.

The Point's nightlife and his visits to the Point's various bars and nightclubs form a counterpart to the narrator's daytime walking. Similar to the day- 
time strolls, these 'nocturnal outings' serve the satisfaction of van Wyk's voyeuristic tendencies:

I walked to the Squireman's Pub, on the first floor of the Arcade, with an entrance from the dark side street.

There were some girls sitting at the bar. One particularly beautiful, with bright crimson-coloured silk slacks came in and out of the place at intervals, and flirted with men. [...]

I looked at her face as long as possible. She was beautiful beyond words. She must be sought-after; judging by her expensive clothes, the gold rings, and diamonds in her ears. Her voice was that of an illiterate child. Realizing defeat, I eventually left for my empty flat. (van Wyk, Man Bitch 1)

From the very beginning of the novella, the narrator thus places himself within the economy of Durban's fictional(ised) 'love industry' which is inextricably linked to the Point area. All of van Wyk's (sexual) relationships are linked to money: he repeatedly buys the women drinks (e.g. 5, 9, 15, 62, 64, 65), pays them for sex (e.g. 10, 23, 65), and the ones with whom he engages in more permanent relationships, he provides with food, clothes, and other things they require (e.g. 11, 19, 23, 25, 61). The monetary component de-romanticises the narrator's phantasmagorical perception of his relationships and defines them as economically driven.

Shanta Reddy, in her review of the novella, argues that "[w]ithout uttering a phrase of economics, it's one of the most powerful critiques of our economic system" (12). Van Wyk's relationships with the various black prostitutes are indicative of South Africa's economy at large where the powergeometries have shifted politically more so than economically (see e.g. Bundy). The monetary component of the narrator's interracial relationships indeed becomes a placeholder for the white man's (seemingly) endless financial power and influence in South Africa. In order for more exclusive claims on the women, van Wyk tries to bind them to himself. He buys Angel, his second girlfriend, a cell phone, reasoning that it "would be an investment on a permanent claim on Angel" (van Wyk, Man Bitch 12). This (stereotypically) moneydefined power-geometry, however, does not take root, and the narrator's "claim" does not last, as Angel repeatedly stands him up for other customers $(12,21)$. This misunderstanding is characteristic for van Wyk's inability to accept that the relationships are a 'commodity exchange'.

The various women in fact soon dictate the protagonist's movements and actions within the Point, even inhibiting his flânerie. As the protagonist be- 
comes involved with the various women, his leisurely walks and outings become less frequent. If the protagonist is joined by one of the women, this happens either as a form of 'service' connected to some sort of monetary compensation or the leisurely outing is imposed on van Wyk by one of the women. After buying Angel a cell phone, for instance, van Wyk relates:

we went for a walk through the nature reserve at Umhlanga Rocks, and sat on the beach looking at the waves, my head on her lap. She looked beautiful and vulnerable. I was getting obsessed with Angel.

We drove back, after a great day, with my left hand holding her two hands in her lap, and my other steering the wheel. (12)

That very night, however, Angel stands him up for the first time (12). At a later point, van Wyk recounts that Luisa, his third girlfriend:

made a call to her friends from a phone booth, and they demanded that I take them for a drive into the harbour. [...] So we drove to the harbour on the Bluff side and back. Then I dropped them all, except for Luisa, who led me to a jewellery shop in the Wheel, and chose a golden ring, which I was obliged to buy. (23)

The various relationships between the narrator and the different women are thus characterised by a strange interdependence, money being an everrecurring theme. While van Wyk may be fully aware of the women's financial constraints and their need to entertain other customers, he nevertheless repeatedly displays fits of jealousy when the women are with other men (e.g. 11, $14,69)$. This contradiction is symptomatic for the narrator's inconsistent actions which lead to recurring conflicts between himself and the women. Already early on in the novella, his behaviour results in Angel publicly humiliating him at Costa do Sol:

'This man was my boyfriend. He gave me this cell phone.' And she showed it to everybody.

'He slept with my best friend. He is doing it to everybody. He fucks around. He has done it to Mbali (spontaneous clapping of hands by friends of Mbali, who has warned her). He is a bitch. He is a man bitch. He is a Boer. He is just another Boer.' (16)

The combination of the word 'bitch' - i.e. a female dog or, in its figurative application, a promiscuous woman or prostitute - with the word 'man' in this scene, which in fact gives the novella its title, bespeaks van Wyk's promiscui- 
ty, immorality, and active libido. At the same time, Angel's insult brings together aspects of sexuality and race (Visagie, "Wit Mans" 238). Van Wyk's labelling as both "man bitch" and Boer - i.e. a white South African of Dutch descent - indeed assigns him the untrustworthy subject position, which is marked as male and white, and, in fact, becomes indicative for the fundamental mistrust that seems to determine the relationships between him (the white subject) and the women (the black subjects). The relationships mirror the fundamental racial antagonism of apartheid's power-geometries which, in turn, are rooted in the colonial power dynamics between coloniser and colonised. Instead of abolishing racial boundaries in accordance with van Wyk's (and the 'rainbow nation's') romantic(ised), non-racialist idea(l), they are thus rather corroborated by the constant question of (un)trustworthiness that destabilises the relationships and fuels the continuous mutual manipulations in the first place.

However, there is a twist to this story. It should be noted that van Wyk deliberately misleads Angel and makes her believe that he has slept with her best friend, Poschia, in order to seek revenge for her standing him up and for him to regain the upper hand in their relationship. One of the things McKaiser criticises about white liberals in South Africa is that they "fancy themselves morally unproblematic allies of black people" (Run Racist 13). Van Wyk's manipulative tendencies and his refusal to accept his relationship with Angel (as well as the other prostitutes) for what it is, namely a 'commodity exchange', challenge his supposed liberal stance and moral integrity. Indeed, his behaviour does not help to overcome racial mistrust towards the white subject, the erstwhile perpetrator of apartheid times, and its stigma. On the contrary, his behaviour speaks to the "relationship paralyses between blacks and whites" which, according to McKaiser, are characteristic for the post-apartheid South Africa's racial relations (73). There remains the question of how to explain the self-destructive nature of van Wyk's relationships with the various prostitutes and their mad(dening) effect on him.

\section{Mental AND Physical Dis-EASE}

Frantz Fanon, in Black Skin, White Masks, offers detailed comment on interracial relationships and their pathological effects. He posits:

Out of the blackest part of [the black man's] soul, across the zebra striping of [his] mind, surges this desire to be suddenly white. 
[He] wish[es] to be acknowledged not as black but as white.

[...] By loving [him] she proves that [he is] worthy of white love. [He is] loved like a white man.

[He is] a white man.

Her love takes [him] onto the noble road that leads to total realization....

[He] marr[ies] white culture, white beauty, white whiteness. (45; original emphasis)

Van Wyk's desires in Man Bitch are strongly reminiscent of Fanon's stance here, even if within a different spatio-temporal context and under different 'racial auspices'. Similar to Jean Veneuse, the protagonist of René Maran's novel Un Homme Pareil Aux Autres, who serves as the basis of Fanon's argument, van Wyk can be said to suffer from an abandonment neurosis. A neurosis is a mental disorder of a non-organic cause which includes stress-related symptoms, such as depression, anxiety, obsessive behaviour, or hypochondria. In contrast to a psychosis, however, a neurosis does not involve "a radical loss of touch with reality" (Oxford Dictionaries). ${ }^{63}$ While a neurosis is a form of 'madness' so to speak, though a "relatively mild" form (Oxford Dictionaries), the question of losing "touch with reality" as part of the 'clinical picture' of a neurosis reminds one of the flâneur's generally phantasmagoric perceptions of the world and the problems resulting from it. Due to the intensity with which the figure of the flâneur is evoked in the novella, van Wyk's flânerie could, in a way, be seen as part of his abandonment neurosis if one considers the flâneur's spatio-temporal belatedness as (part of) his unwillingness to accept socioeconomic and -cultural change. Ultimately, it is this clash of 'illusion' and 'reality' that is characteristic of both the flâneur and the neurosis and it is this clash that has a mad(dening) impact on van Wyk.

While van Wyk's interracial relationships can be seen as his desire to 'renounce' his whiteness, as Niall McNulty ("Reading the City" 67) and Visagie ("Wit Mans" 243) claim, I would argue, that the failing/failed relationships lay bare deeper psycho-social issues; the white anxiety of being left behind in South Africa's new dispensation. Fanon, in accordance with Germaine Guex, ${ }^{64}$ connects abandonment neurosis to the following three primary symptoms: "the anguish created by every abandonment, the aggression to which it gives

\footnotetext{
63 The Oxford English Dictionary defines 'psychosis' as "any kind of mental illness or disorder that is accompanied by hallucinations, delusions, or mental confusion and a loss of contact with external reality".

${ }^{64}$ Fanon's argument is based on Guex' La Nérvose d'Abandon.
} 
rise, and the devaluation of self that flows out of it" (Guex qtd. in Fanon, Black Skin 52-53; original emphasis).

Van Wyk repeatedly displays these symptoms. During his relationship with Angel, for example, his anguish is initially triggered by the fact that Angel does not show up for their arranged night out, and grows due to the Palmerston Hotel, where Angel lives and receives other customers, turning out to be a decidedly inaccessible place for him. It is an interesting detail that he is only ever allowed into Angel's room at the Palmerston Hotel once throughout the novella (van Wyk, Man Bitch 17). Characterised by its inaccessibility, the Palmerston Hotel can thus be seen as a harbinger of how the greater Point area itself remains a distinctly closed space for van Wyk, ultimately never really becoming a 'true home' for him. Opposite to van Wyk's phantasmagorical perception, which proves to be nothing but make-believe, the greater Point area remains a racially divided place. The narrator's aggression, in turn, manifests itself in his wish for Angel "to stop this life of bitching" and telling her that "it was her choice. If she wanted to fuck other guys, then [he] would fuck other women" the night before the éclat at Costa do Sol (15). Unsuccessful with his ultimatum, he then tricks Angel into believing that he has cheated on her with Poschia. The devaluation of the narrator's self, finally, becomes evident not only in his silence during Angel's public humiliation of him, but even more so with his open-hearted confession to Angel shortly after the public scene at Costa do Sol: He confesses he "wanted someone who was prepared to stay with [him], and whom [he doesn't] need to pay to make love to" (17), only to be left behind dumbfounded by Angel's immediate, silent departure. Her reaction to van Wyk's revelation not only constitutes yet another abandonment, it also marks the beginning of another passage through the perpetual 'circle' of primary symptoms linked to his apparent abandonment neurosis. Van Wyk effectively foists the 'duty' to soothe his abandonment neurosis and white anxiety onto the women. The devaluation of the narrator's self is furthermore a sign of his self-victimisation which defers the responsibility to actively confront the cause of (his) racial preconceptions.

The source of neurotic tendencies, as Fanon reminds, can (stereo)typically be explained by "uncover[ing] [...] an analogy with certain infantile elements, a repetition, a duplication of conflicts that owe their origin in [to] the essence of the family constellation" (Black Skin 109). This also applies to Man Bitch where the threads similarly converge in van Wyk's conflictual relationship with his parents. Here is the scene in which the protagonist introduces his parents to Luisa, his third girlfriend: 
My mother greeted Luisa coldly, and didn't want to know me anymore. She said, crying, that she gave birth to me with difficulty, and they stood with me when I refused to go to the army, and asked why I was doing this to them? She didn't know what was wrong with me, and wanted to know why I could not leave the blacks alone? Then Luisa and I left. (van Wyk, Man Bitch 48)

The mother's reaction reveals blatant racism on her part. Within the South African context, such racist presumptions are characteristically linked to Afrikanerdom and its prevalent role in promoting nationalist/separatist thinking that ultimately lead to the apartheid regime. The (psychological) pressure on van Wyk is additionally increased by the mother's reminder of her (and her husband's) dissatisfaction about his decision to evade conscription, which she equates with her disappointment about her son's interracial relationship. For the parents, van Wyk's interracial relationship becomes aberrant as it goes against their definition of white subjectivity in opposition to its black counterpart. Such an attitude, Leon de Kock claims, has to be understood in light of the country's settler history whose missionary work established the light/dark-dichotomy and the resulting association of morality and immorality, civilisation and wildness, with white and black subjectivity, respectively ("The Call" 16). Against this historical background, van Wyk's interracial relationships become a "quite spectacular literary-symbolic engagement with whiteness, dramatising the Trojan Horse of inner instability, the wildness within, repressed and hidden, that gives the lie to whiteness as a monolithic entity", as de Kock compellingly argues - although this point he makes in reference to Marlene van Niekerk's Triomf (23). Van Wyk's interracial relationships can thus be seen as a continuous reiteration of his failure to comply with his parents' expectations as well as a display of "the paradoxical nature of whiteness, its complicity with wildness" (de Kock, "The Call" 16).

Van Wyk re-enforces the historically pre-determined racial deadlock with his interracial relationships: By 'showcasing' his sexual prowess throughout the narrative, he 'appropriates' the (stereo)typical image of the "tremendous sexual powers" of the black man (Fanon, Black Skin 121). The fact that the narrator recalls how Angel "smiled at [his] small penis" when having sex with him for the first time (van Wyk, Man Bitch 9), however, implies yet another devaluation of the narrator's (white) self, even if in a more private context. The incident is indicative of the conflicts that van Wyk's attempted appropriation implies and speaks to his white anxiety. The latter becomes particularly evi- 
dent when van Wyk recounts suffering from potency problems towards the end of the novella (69).

The narrator's racial(ised) fear also becomes apparent during his time as visiting professor in Europe (31-46). While the greater part of the novella is related in past tense, the protagonist's time in Europe is narrated in the present tense. ${ }^{65}$ This tense shift can be seen as an indication of a feeling of 'presence' and 'actuality' that van Wyk's work as a scholar and writer bestows him with, a feeling that cannot be sustained by his life at the Point and the relationships with the various (black) women. The narrator's trip to/through Europe can also be seen as mirroring his privileged position as (white) professor/scholar. It is his (white) privilege that allows him to travel extensively in the first place, while most of his girlfriends are restricted to a life within Durban's Point area. Luisa, who leaves Durban and returns to Maputo in Mozambique, where she finds a job as the manager of a disco and can subsequently afford both a car and a property $(51-52,75)$, is the big exception. Van Wyk, however, is neither able to accept Luisa's independence nor is he willing to leave his life (and job) in Durban behind to move to Mozambique.

The use of present tense to narrate the events in Europe is thus also an unconscious expression of van Wyk's rootedness in, and wish to preserve, his (white) privilege as well as an unconscious attempt to make up for the break with his parents. Furthermore, the trip to/through Europe reflects the opposition of his conflicting private and professional lifestyles. While in Durban, van Wyk's work life is marginalised and negatively stigmatised. The ups and downs of his private life are so prevalent that he loses interest in his job. He, for instance, recounts driving to work with "[a] heavy devastated feeling cramping around the heart" (20), considering work as simply "mindless" (27). In Europe, in contrast, he experiences a period of professional satisfaction. The spatial distance from Durban's Point area provides van Wyk with a 'spacetime of (relative) mental ease', which rekindles his joy for professional conversations and leisurely walks. During his time in Essen, van Wyk recounts long conversations and walks with the American scholar Mary Shannon. One of their conversations revolves around America and its need for "a revolution to transcend its race hatred" with "the revolutionary spirit [...] no longer alive", to which the protagonist replies that a revolutionary spirit "needs love and lots of love, but I do not know what love is, nevertheless I know it can make a difference" (39). The protagonist's statement here is reminiscent of his (initial-

${ }^{65}$ It should be noted that the tense shift is not absolutely consistent, a fact that can, most likely, be attributed to the novella having been self-published. 
ly) romantic(ised) and phantasmagorical perception of life at Durban's Point area. It is no accident that the protagonist's idea(l)s re-surface during his time in Europe. As a 'space-time of (relative) mental ease', Europe becomes a 'safe zone' for idea(l)s of peaceful living across racial boundaries, at least on a theoretical/discursive level. These idea(l)s, however, clash with the protagonist's actual experiences at Durban's Point, proving his idea(l)s to be unrealisable. The discussion is symptomatic for one of the main problems the novella raises with regard to South Africa's race relations: Non-racialism remains, for the most part, a theoretical and discursive endeavour. ${ }^{66}$ This becomes evident in van Wyk's inability to implement such non-racialist idea(l)s into his relationships and, as McKaiser warns, "being in an interracial relationship doesn't mean you grasp the ways in which racism continues to play out" (Run Racist 20).

It is also in this regard that van Wyk's physical dis-ease during his time in Europe has to be seen. While Europe may be a 'period of (relative) mental ease', van Wyk becomes infected with intestinal worms. As a malady of the inner body, the worms become a reminder of the protagonist's (mental) distress and trouble back 'home'. Over the course of his stay in Europe, van Wyk makes repeated reference to his "itching", "slimy", "painful", "bleeding", and "tickly" arse (33, 35, 39, 42, 43, 45), a development that amounts to the externalisation and physical manifestation (or materialisation) of his mental torment which, in turn, is the result of van Wyk's mad(dening) circumstances of life as described in the previous two sections. ${ }^{67}$

The alternation between physical and mental pain (or dis-ease more generally) that dominates the narrator's existence is central to Elaine Scarry's argument in The Body in Pain: She reasons that "pain and imagining are the 'framing events' within whose boundaries all other perceptual, somatic, and emotional events occur; thus, between the two extremes can be mapped the whole terrain of the human psyche" (165). While pain, according to Scarry, "is like other forms of sentience but devoid of the self-extension that is ordinarily the counterpart of sentience, the imagination is like other forms of the capacity of self-extension without the experienceable sentience on which it is ordinarily premised" (162). If physical pain, as Scarry suggests, lacks "self-extension", i.e.

\footnotetext{
66 On non-racialism see e.g. Viljoen, "Non-Racialism".

67 Van Wyk's worm infestation involuntarily reminds one of Dimitri Tsafendas (1918-1999), who stabbed Prime Minister Hendrik Verwoerd in parliament on 6 September 1966. Tsafendas later claimed that he was infested by a giant tapeworm. He was found not guilty of murder by reasons of insanity and remained imprisoned for the rest of his life (see e.g. van Woerden).
} 
it remains within the bodily boundaries, van Wyk's physical dis-ease during his time in Europe gains further meaning. It is not only a 'memento' of his (mental) suffering back in Durban's mad(dening) Point, it also speaks to his eccentricity and/or self-centredness, and ultimately a fostering of his (self-)victimisation. This becomes more evident when taking into consideration the development of van Wyk's dis-ease in the remainder of the novella.

Van Wyk's rapidly deteriorating physical and mental health in the remainder of the novella is triggered by two tragic incidents: Luisa's accident in Maputo in which she loses the child they are expecting, and Mbali's death (van Wyk, Man Bitch 50, 60). The rapid deterioration is reflected in his subsequent more frequent change of (sexual) partners. In the novella's last chapter, three new women (Zodwa, Beauty, and Z) enter van Wyk's life. Compared to the three previous women who dominate his private space for the greater part of the narrative (Mbali, Angel, and Luisa), van Wyk dedicates considerably less narrative space-time to them. "His relationships with these women", as McNulty argues, "has now accelerated and formed a repetitive pattern. They no longer each require a chapter" ("Reading the City" 67). I would reason, however, that the reduced allocation of narrative space-time to Zodwa, Beau$\mathrm{ty}$, and $\mathrm{Z}$ is not only a question of requirement, but also - and maybe more importantly so - a question of appreciation. This is particularly evident in the following scene between Zodwa and van Wyk, which brings to mind his public humiliation by Angel:

I was drunk. Alone was her name. Alone was sitting with me. Why was I sitting with this stupid bitch? Why was I fucking up? [...] I phoned Zodwa. Zodwa I'm drunk. [...] I'm drunk. I've got a confession to make. Today, I'm an emfebe. I'm a bitch. I want to feel like a bitch. I do not want to hurt you. I love you too much, Zodwa. Zodwa, don't feel sorry for me. Just understand. I love you despite everything, but today I'm not going to be alone. I'm going to be with Alone. Betrayal, I hate it, changing from one person to the next in my life. I hate it.

In a wind enwrapping me in a curtain at the window, Zodwa was suddenly there. The flat was dark. She cared for me. I told her that Alone was on her way. It hurt so much I could not feel. She left, and said that she wanted to be alone, to think. As she left, she saw Alone arriving. (van Wyk, Man Bitch 71-72)

This excerpt is the climax of van Wyk's abandonment neurosis, which here finds a particularly dramatised expression through the 'alone/Alonewordplay'. Considering the outcome of the episode - he sends Alone home 
and follows Zodwa to her flat where he breaks down in tears on her bed and is not allowed to touch her - van Wyk's plan not only fails, but once more highlights his self-centredness, manipulative tendencies, and incomprehension for his partners' needs. This becomes particularly evident in his increasing selfvictimisation that is used to account for and manipulate the meaning of particular events - for himself and the (implied) reader. Recovering from a nervous breakdown at his parents' house in Bloemfontein, the place he probably least expected to find himself, van Wyk recalls the following scene:

I played tennis against the wall until the retarded boy from across the road, joined me. He told me how he assaulted a maid with a golf stick, for misplacing the keys to his fishing trunk. I felt nauseous. Even the innocent and the disabled had internalized the abusive behavior of the place. (73)

It is striking how van Wyk, having placed a (secure) distance between Durban's Point and himself, seems to regain a reflectiveness that he does not exhibit when interacting with his (sexual) partners. While the racism displayed by the boy seems to provoke repulsion and disgust on van Wyk's part, there seems to be little remorse for his disrespectful treatment of his (sexual) partners. Van Wyk's conduct towards his (sexual) partners is no less disrespectful and degrading, as the particularly graphic and gruesome ending of the novella demonstrates:

$\mathrm{Z}$ returned from her rural home, and she was menstruating. On Thursday, Zodwa surrendered herself. Hein [i.e. her lawyer] took her with his car to the court. She stumbled, and she clung unto him. She phoned her baby boy, and this was where tears ran silently down her face. In a court office she was attached - 'ball and chained' and assisted by two big guards to the van, taking her to prison. My penis took a deep slide into the bloody darkness of Z. (76)

Van Wyk's disrespect functions on several levels. The overlapping or confluence of Z's and Zodwa's narratives in the novella's ending illustrates the impact of the reduced narrative space-time given to them: Not only are $Z$ and Zodwa 'worth' less narrative space-time, they also have to 'share' it, so to speak. Z's character, moreover, is reduced to a single letter, an abbreviation of a name, which can be seen as a further (narrative) de-valorisation. $Z$ 's negative value is corroborated in her portrayal as van Wyk's (sexual) solace. $Z$ becomes a mere placeholder for Zodwa now that the latter reports to the police in order to start serving her prison sentence. Van Wyk's decision to have sexual intercourse with $\mathrm{Z}$ while she is menstruating is also strangely reminiscent of a simi- 
lar scene earlier on. During his relationship with Luisa, van Wyk recounts how "her periods came. Fucking someone with periods, brings bad luck. We made love, nevertheless" (24-25). The narrator's willingness to have sexual intercourse with Luisa despite his awareness of her apparent (superstitious) beliefs can be seen as a clear sign for his disrespect. The disturbing image that the novella's last sentence evokes shows the same level of disregard towards $\mathrm{Z}$. At the same time, it seems impossible not to think of Joseph Conrad's Heart of Darkness. The protagonist's 'venture' "into the bloody darkness of Z" (van Wyk, Man Bitch 76) is reminiscent of the narrator, Marlow, in Conrad's novella, who travels up the Congo river to recover the ivory trader Kurtz from the Company's Outer Station, thus entering 'deep' into the Congo's interior, i.e. its 'heart of darkness'. The (sexual) act's 'bloodiness', similar to Marlow's voyage up the Congo River, reminds one more of an act of conquering than an act of love. The menstruation blood, which is excreted by the female body at the end of a fruitless menstrual cycle, becomes a symbol of the ineffectiveness of van Wyk's (initially) romantic(ised) idea(l)s of a peaceful life together across racial boundaries in post-apartheid South Africa. Again, similar to Conrad's novella, which ends with Marlow lying to Kurtz's fiancée, telling her that his last words were her name, thus maintaining the fiancée's romantic(ised) picture, Man Bitch ends in an act of dis-respect and van Wyk does not seem to (want to) see the reasons for the repeated failure of his relationships.

The protagonist's lack of self-reflection with regard to his relationships reminds one of Aubrey Tearle, the protagonist of Ivan Vladislavić's The Restless Supermarket. Vladislavić's novel follows the white, dissatisfied, retired proofreader, Aubrey Tearle, who struggles with the post-apartheid changes within Hillbrow and whose world is turned upside down when his favourite café, Café Europa, announces its closing. Sarah Nuttall reads the novel from the vantage point of the 'ageing white man' whom she sees as occupying a position of refusal. ${ }^{68}$ According to her:

[Tearle's] fantasy of Europeanness [despite the fact that he has never been to Europe] is also the refusal of Hillbrow, and Johannesburg, at least as they are becoming after political transition. Specifically, it is the refusal of the transformation of Hillbrow from a mostly white, orderly suburb inhabited by large

\footnotetext{
68 Examples within a Capetonian context are J.M. Coetzee's Nobel Prize winning Disgrace or André Brink's The Rights of Desire. Both book's protagonists, David Lurie and Ruben Olivier, are forced to (re-)evaluate their position (as 'aging white men') within post-apartheid South Africa.
} 
numbers of Eastern European immigrants who benefited from apartheid privileges into a diverse, disorderly Afropolitan inner-city quarter. (Entanglement 45)

Similar to Aubrey Tearle's inability to accept the socio-cultural and -economic changes within post-apartheid Hillbrow (Johannesburg), the 'aging white' narrator's increasingly reprehensible conduct in Man Bitch bespeaks his failure to accept the changing/changed 'face' of Durban's Point area and his inability to adapt to his (self-imposed) living space. The more the protagonist's romantic(ised) idea(l)s clash with the 'fictional(ised) reality' around him, the more dystopian/apocalyptic his perception of the Point area becomes and the more his mental and physical health deteriorate. Van Wyk's increasingly dystopian/apocalyptic perception and his growing dis-ease speak to 'the aging white man's' (racialised) fear of being left behind in South Africa's new dispensation. His dis-eased body thereby becomes a placeholder for the white subject position within post-apartheid South Africa and for South Africa's ailing/ailed body politics at large, where 'whiteness just isn't what it used to be' (Steyn) and needs to be re-negotiated within the country's newly formed democracy. This re-negotiation includes the mediation of white privilege and (unconscious) racialised attitudes. Man Bitch is a problematic piece of autofiction in this regard as it portrays van Wyk as being unaware of his white privilege and unsympathetic towards the continuous relevance of race in post-apartheid South Africa. The novella is, however, simultaneously ahead of its time as it portrays the catch-22 situation of a white South African liberal who can only go wrong within the post-apartheid context whether he does something or not (McKaiser, Run Racist 95). The recent \#RhodesMustFall and \#FeesMustFall movements have shown how current the racial tensions at play in Man Bitch still are. In a comment on the 2015 \#RhodesMustFall protests, McKaiser states: "It is little wonder that campaigns to remove the images of colonial powers like the statue of Cecil John Rhodes gained so much momentum at the University of Cape Town: racial consciousness is a South African thing, just as much as rainbow myth-thinking is a South African pastime" (Run Racist 90). This seemingly gridlocked and contentious condition of post-apartheid South Africa's racial relations forms the basis of Man Bitch, which turns out to be a discursive attempt of 'transcending' the apartheid past and its racial divisions. Man Bitch, however, attests more to the mad(dening) difficulties such a transition implies. The novella's various mad(dening) components - van Wyk's mad(dening) actions and behaviour, his mad(dening) relationships which are biased by (post-)apartheid's mad(dening) racial relations, as well as the 
mad(dening) effects of his living conditions in the Point and the mad(dening) effect of his repeatedly failing/failed relationships - highlight the extent to which a hybrid, non-racialist South African identity still seems to 'remain an idea(l)' (Viljoen, "Non-Racialism"). "Instead of a creative tension between internal and external reality, where illusion can be explored", to borrow Long's argument, "the space is foreclosed and the oppositions of apartheid are solidified" (72). Ultimately, it seems that just as van Wyk is not at ease in Durban's mad(dening) Point area, so Durban's Point area, and by implication South Africa more generally, is not (yet) a place at ease. 


\subsection{K. SELLO DUIKER'S THIRTEEN CENTS}

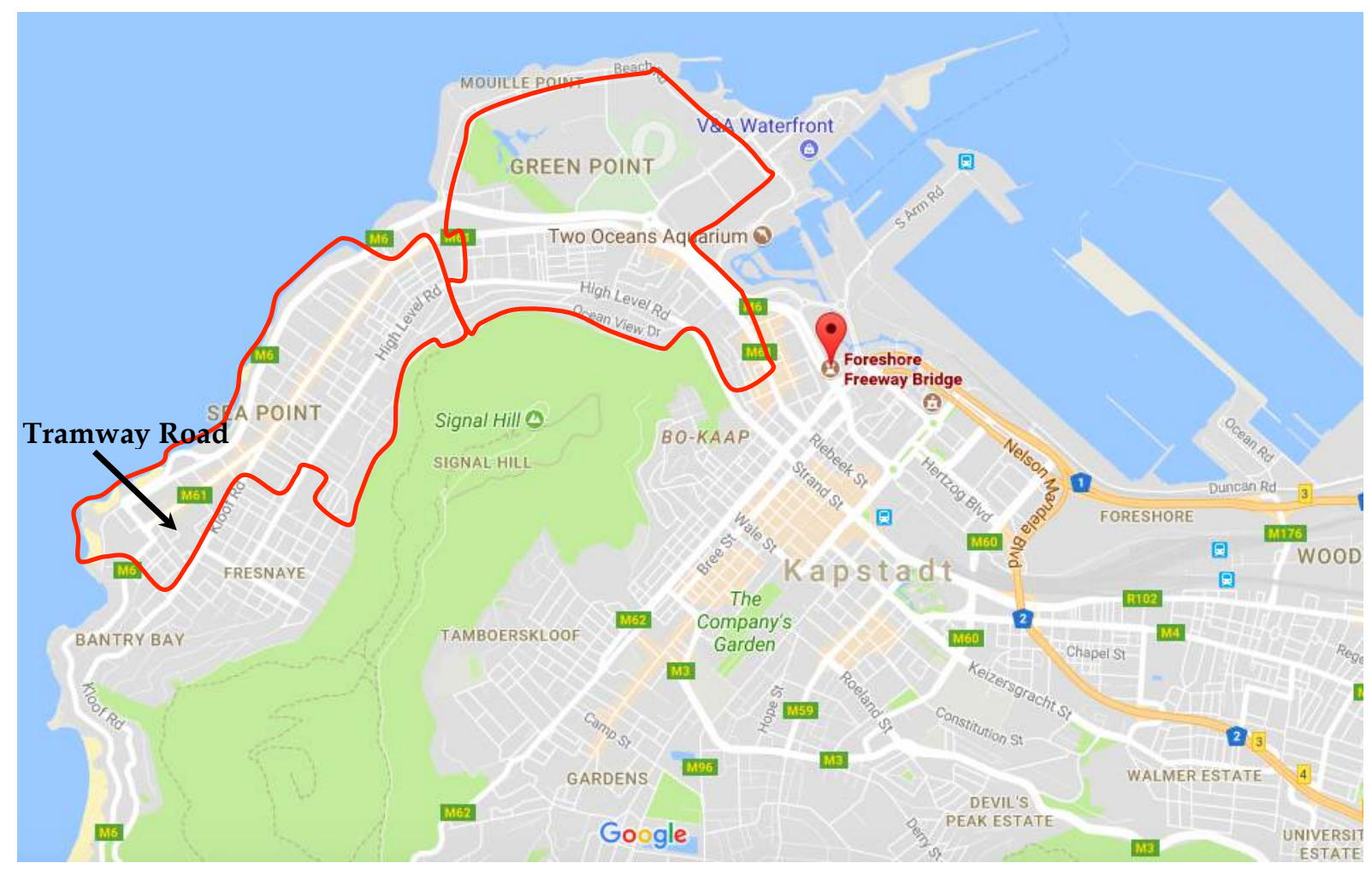

Figure 9: Map of Sea Point and Green Point.

Sea Point and Green Point are two affluent suburbs of Cape Town. Green Point comprises the area between the north-eastern slope of Signal Hill and Bay Road in the south and from the V\&A Waterfront (Napier Road, the M6/M61, and Portswood Road being the eastern perimeters) to shortly before Three Anchor Bay where Helen Zuzema Boulevard turns into Bay Road, with Glengariff and Hill Road forming the area's other two western perimeters. Among its more prominent landmarks are the Green Point Lighthouse, the Cape Town Stadium (nicknamed the "Toilet Bowl" by locals), and the Green Point Urban Park. Sea Point is the adjoining area along the M6 (Beach Road), M16 (Main Road), and High Level Road on the eastern slope of Signal Hill. To the south, Sea Point neighbours Bantry Bay and Fresnaye, where its southern perimeter runs along Fir Avenue, Kloof Road, Avenue Française, St Johns Road, and Avenue de l'Hermite (see Figure 9). Sea Point is well-known for its beautiful beaches and its promenade that runs all the way past Three Anchor Bay, Green Point Urban Park, and Green Point Lighthouse right into the centre of Mouille Point. Similar to Durban's beachfront, Sea Point and Green Point received a considerable 'facelift' prior to the FIFA World Cup in 2010 (Phillip). 
European settlers began to take up residence in Sea Point in the early nineteenth century and in 1839 Sea Point and Green Point became a joint municipality ("Sea Point"). It is, however, in the second half of the nineteenth century that the area became more popular, first due to the tramway and then because of the additional train services that were established between Cape Town and Sea Point in 1862 and in 1892, respectively (Paulse 39). As a result, Cape Town's white middle-class residents started to leave the increasingly overpopulated and racially mixed inner city and settle in Sea Point and Green Point (Bickford-Smith, "The Origins" 37; Hart 119). While the population of Sea Point and Green Point consisted of mostly white, middle-class residents at the time, "[c]oloureds who met the labour needs of the dominant population increasingly moved into the area" (Paulse 50). They settled in coloured enclaves such as Tramway Road and Ilford Street, at the south-east end of Sea Point (see Figure 9), where the tramway company built housing for its employees close to Sea Point's tramway terminal (Paulse 35, 51). Such racially mixed working-class residential areas were common in Cape Town - Woodstock, the Waterfront, and District Six being further examples (Bickford-Smith, Ethnic Pride 127-128, 151). The coloured enclave in Tramway Road and Ilford Street survived after the closure of the tramway in 1939 through to the beginning of 1961, when coloureds were forced to leave the area (Paulse 58).

The forced removals from Sea Point and Green Point were among the first in Cape Town (Mesthrie 65). On 5 July 1957, the Table Mountain area was proclaimed a White Group Area (Mesthrie 64; Paulse 180). Consequently, "[c]oloureds and Indians in Newlands, the Gardens, Tamboerskloof, Oranjezicht, Green Point, Sea Point, Clifton, Bakoven and Camps Bay - the places affected by the Table Mountain Proclamation - faced removals from their homes" (Paulse 180). Coloured residents in these areas were initially given two years to vacate their homes (Mesthrie 64; Paulse 184). The residents in Tramway Road and Ilford Street, however, repeatedly succeeded in delaying their removal until the end of 1961 on the legal grounds of lack of alternative housing (Mesthrie 66-76; Paulse 186-213).

Since the demise of apartheid, Sea Point and Green Point have undergone various ups and downs with regards to their public image (Morris et al.). In the late 1990s and early 2000s, Sea Point and Green Point saw an influx of crime. Cape Town was afflicted with several bomb attacks between November 1999 and August 2000, two of them in the city's gay scene (Joseph; Lovell; Merten). The situation culminated in the so-called 'Massage Massacre' in 2003 where nine men were brutally killed in the Sizzle massage parlour in Graham 
Road, Sea Point, an incident that marked the area "as a dangerous and violent no-go area" (Morris et al.). Merten reports how "the murders have revealed another side of the Mother City - an underworld of gangs and drugs that has steadily crept from the Cape Flats to other areas in the peninsula as prostitution, protection rackets and narcotics provide lucrative markets throughout the city". It is this drug- and crime-related side of post-apartheid Cape Town aside from the bomb attacks - that provides the setting for K. Sello Duiker's novel.

Among other topics, Duiker's novel addresses the issues of homelessness and street children in Thirteen Cents. In an article Duiker wrote for the Rhodes Journalism Review in 2004, he notes how "[f]or some reason street children seem to stand out more in Cape Town than elsewhere. [...] Cape Town's street children are very much part of the city" and recounts a period of three weeks he spent with a group of street children in search of a lost friend of theirs ("The Streets" 9; see also "The Last Word" 28). It is in this respect that the Foreshore Freeway Bridge, Cape Town's infamous 'unfinished bridge' northeast of the CBD (see Figure 9), has to be mentioned. The bridge prominently features in Thirteen Cents as Azure, the novel's protagonist, is forced to move there by Gerald, one of the drug lords he gets involved with. The Foreshore Freeway Bridge, which was left unfinished in 1977 due to financial restraints, used to be a popular shelter for street people, until the city installed "a sprawling grid of tightly spaced rocks, planted vertically" in early 2013 to prevent the homeless from sleeping there. Many of them had lived there for many years and many a life story of these street people is linked "to the dark, criminal reputation of the former shanty" (Earnest). In 2016, the Foreshore Freeway Bridge made headlines with Cape Town mayor Patricia de Lille announcing plans to complete the unfinished bridge within the next five years (Bamford).

According to the City of Cape Town's Integrated Annual Report 2015/16, the city's "overall crime levels since 2011/12 have been around twice the national average. [...] Drug crimes and theft/burglary related crimes are among the most frequently occurring crimes in the city, and Cape Town has a higher incidence of these crimes than other major metros" (17). Even though crime still is one of the city's major concerns, the public image of Sea Point and Green Point has recovered since its downturn around the turn of the millennium (Morris et al.). Sea Point and Green Point have become social and cultural hubs and have served as paramount examples of Cape Town's (racially and socio-economically) inclusive policies (see e.g. Sea Point Days). According to Marianne Merten, "Sea Point occupies a special place in the city: its Jewish and 
gay communities are well established, and it has been a haven for black South Africans since the apartheid years". The situation is similar for Green Point whose nightlife - particularly its gay clubs - and dining scene around Somerset Road north-west of Cape Town's CBD is well-known (see e.g. G. Visser). Particularly the Sea Point Promenade with its public gym, playgrounds, and further recreational opportunities, which are frequented by the more affluent and financially less fortunate alike, is celebrated as "Cape Town's most successful public space" (Hodes). Brett Petzer characterises Sea Point's Main Road as "a robust mix of good value shops where astute working-class shoppers can stretch a budget, and a growing (but far from dominant) presence of determinedly elite shops and restaurants" that "coexist on every block". This socioeconomic tension is also reflected in Duiker's work.

Kabelo Sello Duiker (1974-2005) was born in Soweto as the eldest of three sons. He attended Redhill School, a private school in Sandton, Johannesburg. In an interview, his mother, Angeline Duiker, recalls: "He started [schooling] when it was still Bantu education, but we made a conscious decision as parents to take our children to private schools. At that time we were allowed to, but they were mixed schools. So he had that, but we lived in the township [...]" (qtd. in Demir et al. 27). Duiker was an avid reader growing up, a passion he shared with and, according to him, owed to his mother (Duiker, "The Last Word'" 28; Demir et al. 27). He and his mother would "recommend books to each other and share their favourite passages from the ones they were reading" (Demir et al. 27). In 1995, Duiker went on to study Journalism and Art History at Rhodes University (Duiker, “The Last Word'” 27; Demir et al. 27). On completion of his BA, he moved to Cape Town in 1998, where he studied copywriting (Duiker, "The Last Word"” 28; "Interview with Victor Lackay" 19). He was, however, expelled from university for missing classes for three weeks due to his 'odyssey' with a group of street children in search of one of their friends. The events of these three weeks were to become Thirteen Cents, the first draft of which Duiker wrote after his expulsion from university (Duiker, "The Last Word'" 28 and "The Streets" 9). Duiker returned to Johannesburg after two years (Viljoen, "K. Sello" xviii) and subsequently worked as a copywriter, a scriptwriter for television, and a commissioning editor at the South African Broadcasting Corporation (SABC) (van der Merwe, "In Memoriam"). On January 19 2005, K. Sello Duiker took his own life. In his tribute to Duiker, Sam Raditlhalo writes: "He may have died by his own hand, but there is no doubt that what killed him was a potentially lethal illness that is stigma- 
tised, little understood and often poorly managed" ("'The Travelling Salesman'" 96). Duiker had suffered from bipolar affective disorder.

Duiker is the author of three novels: Thirteen Cents, The Quiet Violence of Dreams, and The Hidden Star. The latter was published posthumously. Thirteen Cents was awarded the 2001 Commonwealth Writers' Prize for Best First Book in the African Region. For The Quiet Violence of Dreams, Duiker won the 2002 Herman Charles Bosman Prize. "Truth or Dare", a short story of Duiker's, was published in the Mail\&Guardian (Raditlhalo, "'The Travelling Salesman'” 96). As I have argued elsewhere, together with Danyela Demir and Alan Muller, Duiker's "first two novels in particular were pioneering with regard to breaking taboos such as (black) same-sex relationships, male prostitution, and psychosis" (31). Writer and academic Sally-Ann Murray similarly highlights how Duiker's work "tackles difficult experiences in gritty urban subcultures [...] and reminds us as South Africans of how much we still struggle to - refuse to? - accept" (qtd. in Demir et al. 29).

Thirteen Cents, the focus in this second half of the chapter, is predominantly set in Cape Town's Sea Point and Green Point of the late 1990s. The novel follows the street child Azure who prostitutes himself to older men in order to make a living on Cape Town's streets. Azure furthermore has to comply with the arbitrary rules of several coloured gangsters. After falling into disgrace with Gerald, the merciless leader of the gangsters, Azure climbs up Table Mountain where, in an apocalyptic and surreal ending, he relishes Cape Town's destruction.

With Duiker's death, South Africa indeed lost the second of its "two [...] most promising writers to emerge in the post-Apartheid era" (Mzamane, Introduction xi) within the scope of a mere month. Phaswane Mpe, to whom Duiker was often compared (see e.g. S.-A. Murray), had died on 12 December 2004. The two author's untimely deaths were honoured in Words Gone Two Soon, a collection of tributes, interviews, criticism, short fiction, and poetry edited by Mbulelo Vizikhungo Mzamane. Despite his popularity, Andy Carolin and Ronit Frenkel, in a joint article, maintain that Duiker's novels have not (yet) received their due attention within academia (36). Brenna Munro, together with Raditlhalo in his tribute to Duiker in "The Travelling Salesman", is one of the few scholars working on both Thirteen Cents and The Quiet Violence of Dreams. She reads Duiker's first novel "as a riposte to the triumphalist tendencies of 'rainbow' nationalism [...] perhaps, an un-coming-out novel" and argues that "[r]ather than offering images of rebirth and a family romance of nation, this novel is about orphanhood" (199). Raditlhalo, in another article, 
similarly discusses "the problematic of sexuality as a currency to those that do not have nuclear families" and argues that Thirteen Cents "is a harrowing read that is unsparing of the disintegration of social mores and values, and renders African $u b u n t u / b o t h o$ insufficient to rescue Azure/Blue from a life of penury" ("A Victory" 273, 276). Shaun Viljoen, in his introduction to the novel's American edition by the Ohio University Press, reads Thirteen Cents as a coming-ofage novel that "is as much about Azure's interrogation and exploitation of the temporal and spacial dimension of his urban world as it is about the social and sexual dimensions" ("K. Sello" xv). Though somewhat less optimistic than my own interpretation, Viljoen sees the novel's ending as "hold[ing] a moment of reassurance for both Azure and the reader" (vxii). Timothy Johns looks at the novel from the angle of "contemporary South African masculinity" and shows how "the novel challenges the idea that 'homosex is not black culture' - that is, the idea that African men are somehow more 'naturally' connected to traditional culture than modern economics" $(250,252)$. In his article, Johns makes recourse to the history of South Africa's mining industry and shows how same-sex relationships were common among mineworkers. Danyela Demir, in turn, offers a reading of Duiker's first novel in the light of racial melancholia. She highlights the importance of race as a topic in the novel and argues that "Azure's in-between position and the evocation of the figure of Sara Baartman during Azure's first stay on Table Mountain suggest that the racialised subject's quotidian experiences speak of violence, loss, and a subsequent melancholia" (155). Tom Penfold sees Thirteen Cents as "bear[ing] witness to the perpetuation of a fundamentally dystopian society" (993), and Mamadou Abdou Babou Ngom regards the novel "as an indictment of South African society" and uses the novel as a companion to a more sociological discussion of street children in post-apartheid South Africa. Meg Samuelson, even though only in passing, makes reference to Thirteen Cents in her discussion of the Dutch East India Company's history in Cape Town ("(Un)Lawful Subjects"), and her analysis of the sea as "a medium eminently suited to the expression of change" in recent South African fiction ("Sea Changes" 10). J. L. Powers, finally, reads Duiker's novel alongside the works of other black writers such as Niq Mhlongo, Sifiso Mzobe, and Masande Ntshanga, whose fiction, according to her, "frequently portray[s] protagonists embarking on lives of crime" (32-33). She then opposes them to the classic 'detective novel', a genre she sees as predominantly occupied by white authors, and offers the rather problematic conclusion that "[o]ne could understand this [generic opposition] as a social impetus that subconsciously equates white citizens with law and order and black 
citizens with lives of crime - an overly simplistic understanding but one with some basis in reality, given South Africa's past and present" (33).

In my reading of Duiker's Thirteen Cents, I will show how Azure's continuous sexual and physical abuse turn Cape Town into a mad(dening) place for him. The preservation of apartheid's bioculturalist racial concepts is central to Azure's continuous suffering as it is the 'mixed message' of his physical appearance - he has a light, brown skin complexion, but blue eyes - that constitutes a threat to various gangsters and their attempts at 'playing white'. Eventually driven out of the city, it is through the mad(dening) dreams and hallucinations atop Table Mountain that Azure is able to mentally free himself from the socio-political and -economic constraints of the mad(dening) postapartheid city and to re-kindle the connections to his cultural roots. I thus consider aspects of madness, as deployed in Duiker's novel, as serving a discursive space of self-determination and as an empowerment of black subjectivity.

\section{CAPE TOWN: '(STEP-)MOTHER(LY) CITY'}

Duiker's novel depicts Cape Town as a place that stands in opposition to the city's postcard image. It is particularly Cape Town's prominence as the 'Mother City' against which the novel pins its counter narrative of the orphaned street child Azure.

Initially, Cape Town is a place of refuge for Azure, a place to turn the page and start over after the brutal murder of his parents in Mshenguville, a former informal settlement in Mofolo, Soweto. 69 "The streets of Sea Point are my home" (Duiker, Thirteen Cents 1), Azure explains at the outset of the novel. Despite the fact that he changes his place of dwelling several times during the novel, Cape Town's streets become Azure's home-place, one he even defends against the stereotypes of others, as can be seen in the following exchange with Oscar, a hiker Azure encounters on Table Mountain:

'So what, you live with homeless people?'

'We have a home. It's just not your normal kind of home with a kitchen and all that stuff but it's still a home.' (116)

\footnotetext{
69 The inhabitants of Mshenguville were resettled to the Lehae housing project in Lenasia, a township south of Soweto, between 2007 and 2009. As Mshenguville's former residents were relocated, the settlement's shacks were gradually demolished, as the area was to become a park (Pongoma).
} 
Azure may be defending more himself here than his actual home-place, which at this point in the novel is the Foreshore Freeway Bridge (115-116). His insisting on homeless people "hav[ing] a home", even if it is not the "normal kind of home", reflects one of the novel's central issues: the question of Cape Town's '(un)habitability' (and by implication that of the South African metropolis more generally), to borrow AbdouMaliq Simone's concept. Simone proposes: "what if the so-called uninhabitable does not necessarily point to a depleted form of urban life but simply a different form - one that constantly lives under specific threats and incompletion" (Always 10-11). Such a reconceptualisation, according to Simone, allows one to focus on the potential of such seemingly uninhabitable spaces/places, considering how Asian and African dwellers, often out of necessity, convert seemingly uninhabitable spaces/places into habitable ones (Always 16-23; see also "Uninhabitable?").

Rather than being the hoped-for 'Mother City' and replacing Johannesburg - a place that, with the murder of his parents, became uninhabitable Cape Town thus turns out to be a 'Step-motherly City' instead. The Cape Town of Duiker's Thirteen Cents is indeed a Januform beast: "She's bad, Cape Town. She takes you in, in the beginning, but be careful. She'll destroy you if you're not watching" (116), as Azure attests towards the end of the novel. However, despite the fact that Azure's position within the city is both fraught with uncertainty and pervaded by power-geometries to which he is, at times, forcefully subjected, he constantly re-negotiates Cape Town's uninhabitability in its various guises.

The city is step-motherly because it keeps Azure 'afloat' and yet simultaneously threatens to let him 'drown'. It forces him to constantly walk (through) its streets. Early on in the novel, Azure relates: "I walk a lot. My feet are tough and rough underneath" (2). Tom Penfold thus posits that "the narrative continually evokes three motifs: walking, feet and footwear" (998). Contrary to Penfold, who claims that these motifs bespeak Azure's spatial freedom within the post-apartheid city, I would argue that Azure's perambulations are more goal-oriented. He is constantly in search of food or his next trick to make some money. For Azure, walking is - very much in contrast to the narrator's (initial) strolls through Durban's Point in Johan van Wyk's Man Bitch - a necessity. In order to survive on Cape Town's streets Azure needs to be just as "tough and rough" (2) as his feet, a lesson he is to learn the hard way. Furthermore, apartheid may officially have come to an end, but Duiker's novel depicts life in Cape Town's underbelly as still very much spatially and racially divided. While the cityscape was formerly regulated by the manifold apart- 
heid laws, in Thirteen Cents it is dominated by pimps and gangsters of the likes of Allen, Gerald, and Richard. Duiker's novel thus highlights the socioeconomic conditions of the post-apartheid city's less fortunate inhabitants, the street children, by turning the city's hidden structures inside out and rendering them visible.

Cape Town is furthermore step-motherly because it claims " $t$ the arrest of [Azure's] childhood development to a middling adulthood" (Raditlhalo, "A Victory" 273). On the day Azure turns thirteen, a number that he equals with adult- and manhood from the outset of the novel, he meditates on the importance of grasping the consequences of entering adulthood:

It's my birthday today. I'm thirteen. I feel it too, all those numbers. I can see them clearly and they all make thirteen. One. Three. I must understand that number. I must understand what it means to be a grown-up if I'm going to survive. That's what they all keep telling me. Grow up. Fast. Very fast. Lightning speed. Everything is always like that. Quick. You must act quickly. Understand quickly. Otherwise someone will fuck you up nicely. (Duiker, Thirteen Cents 6667)

Azure's rite of passage is thus one that happens under immense pressure and it is striking how nuanced his reflection on the different layers of pressure on him is. Azure's Cape Town not only puts enormous time pressure on him to grow up "very fast", even "lightning speed", it also requires a mental and physical agility on his part. Either he "act[s]" and "understand[s] quickly" how adult life on Cape Town's streets works or "someone will fuck [him] up nicely". Azure's premature 'coming of age' is thus linked to enormous responsibilities.

One of the most important responsibilities the step-motherly city imposes on Azure, besides making money and finding food, is emotional strength. Shortly before his thirteenth birthday, he asserts: "Men don't cry. And since I'm nearly thirteen I mustn't cry. I must be strong. I must be a man" (23). Little does Azure know at this point of the novel how strong he has to be and to what extent his emotional strength is to be tested. In a moment of cannabis induced weakness, Azure calls Gerald "kaffir" (19) and is subsequently beaten up, tortured, kept prisoner, and abused by Gerald's lackeys, Sealy and Richard (41-55). It is during his time of confinement that the (city's) exigence of 'being strong' is at its most urgent.

The criminal and opaque power-geometries of Cape Town's street life (see next section) - to which Azure, at least for most of the novel, falls easy 
prey - add a further layer to the city's step-motherly character. Cape Town, in Azure's eyes, is a lonely, fearsome, and hellish place:

I know what fear is. I know what it means to be scared, to be always on the lookout. I know what it means to hear your own heartbeat. It means you are on your own. The world is watching you but only you can hear the music. The mad music of bicycle spokes and speeding cars. I know what it feels like to hear your own fear beating in your ear. I know what it feels like to bite the insides of your mouth to control the fear. I know what it feels like to bite your nails till your fingertips are raw and sensitive to everything you touch. I know fear. And I hate it. I live with it every day. The streets, they are not safe. They are roads to hell, made of tar. Black tar. (66)

Other characters' judgement of the city is similarly negative, and similarly speaks to the city's imperious character and the difficult interdependence between the (post-apartheid) city and its (street) people. Early on in the novel, Joyce, Azure's ersatz mother of sorts, confirms Azure's sentiment when stating: "Cape Town can be so lonely" (11). Vincent, with whom Azure "hiked to Cape Town" after his parents' death (90), warns Azure in similar vein: "You must look after yourself, bra. Do you understand that? No one's going to help you in Cape Town. You must do everything yourself" (98). In an earlier conversation between the two, Vincent reasons: "'Cape Town is fucked up.' [...] 'And the people. Don't forget the people. They're also fucked up'" (37).

Life in Cape Town, the 'Step-motherly City', proves to be a draining experience for Azure, both physically and emotionally, despite his attempt to make the (implied) reader believe otherwise. Shaun Viljoen rightly argues: “As the novel's title suggests, the destructive forces in Azure's worlds continually work to reduce him to near nothing, to a meager thirteen cents, to an object whose value is merely money" ("K. Sello" $\mathrm{x}$ ). This reductionist characteristic of the city is mirrored in Cape Town's eerie ability to (re-)name people. Azure's renaming to Blue (Duiker, Thirteen Cents 56) makes his former name obsolete and with it his 'true' subjectivity is nullified..$^{70}$ On Cape Town's streets,

\footnotetext{
70 Raditlhalo rightly points out that this renaming is an allusion to Toni Morrison's The Bluest Eye (“'The Travelling Salesman'” 98). Morrison's novel, set in Lorain, Ohio, tells the story of the black girl Pecola, who, constantly told how ugly she is, starts fostering a burning desire to be white and have blue eyes. Repeatedly raped by her alcoholic and violent father, Pecola becomes pregnant. The child, however, dies after its premature birth. In consequence of these traumatic events, Pecola becomes delusional, believing that her wish for blue eyes has been granted. While Azure's seeming madness is a parallel to Pecola, his rejection of being (believed to be) white due to his 'misleading' light skin complexion and blue eyes is in stark contrast to Pecola's wish to be white and have blue eyes.
} 
everybody becomes someone new/else and nobody can be trusted to be who they say they are. An ever-present aspect of pretence is thus a further devious characteristic of the mad(dening) 'Step-motherly City'.

Sea Point, "the safest place to be at night" according to Azure (3), becomes a counterpoint to Cape Town's CBD and the 'Step-motherly City's' adverse and contradictory disposition. Broken Bath Beach in Sea Point, where Azure's sleeping (and dwelling) place is located, is a 'safe place', an emotional anchor point and place of clarity, that helps Azure to balance out the exigent demands of Cape Town's (street) life, at least until he is forced to leave Sea Point and join Gerald and his gang under the bridge at Green Point (57). Shortly after his relocation from Sea Point, which is an uncanny reminder of the forced removals under the apartheid regime, Azure reminisces:

Fuck knows how many things I've lost along the way. The way in Cape Town, it's a long road, winding. I'm always lost, that's why I hide out in Sea Point. Get it? 'See Point.' That's where my eyes are. That's where I can see the best. I miss Sea Point. And I know that I can never go back there. (65-66)

The question of (in)visibility Azure ponders in the above passage is closely linked to aspects of Azure's (be)longing. On the one hand, there is Gerald's claim of ownership over Azure (57) which incorporates Azure into the powergeometries of Cape Town's street life. The security that comes with this incorporation is, however, an ostensible one at best and one that comes at a high cost. It entails not only a degrading of the net worth of Azure's subjectivity which is reflected in Azure's renaming, but also the dissolution of Azure's/Blue's safety net. Vincent/Mandla, Azure's "only connection" in the city (97), leaves Cape Town for Port Elizabeth and Joyce, Azure's ersatz mother of sorts, betrays Azure's trust. Azure's former safety net is replaced by his total dependence on, and permanent availability for, Gerald. On the other hand, there is the issue of Azure's longing to (both physically and emotionally) appertain to the city and for the 'Mother City' to become his new home-place. Azure's continuous perambulatory movement between Sea Point and Cape Town's CBD, however, speak to his state of 'non-belonging'. Either hiding from Gerald and his lackeys, running away from them, or on the lookout for a new trick, Azure is constantly 'adrift'. He becomes the epitome of the 'unwelcome element', the street child and street hawker, in the post-apartheid city's postcard image. 
Moments of rest and relaxation such as in the following passage, which is reminiscent of similar scenes in Johan van Wyk's Man Bitch and Lewis Nkosi's Mating Birds discussed in the first half of this chapter, are rare:

We [Azure and Bafana] sit there and listen to the waves. It feels like flying. I stretch out my arms and stand up to stretch out my back.

'They said Gerald fucked you up,' he says.

I look at him and walk over to the water's edge. If only it was that simple, that easy, Bafana, I say to myself and spit into the water. I stand there and the wind blows. The sun is getting closer to the water. Boats go by. I wonder if they can see me. I wonder how far it is from here to them. They look small in the distance like toy boats. That black man walks beside me and also looks out over the water. He looks at me and grins. There is something familiar about his grin, something naughty about it. He looks like a bad man, the kind who would steal an old woman's bag. (78-79)

In the above scene, the beach initially is a place of peace and freedom. Azure is temporarily able to forget the 'Step-motherly City' and its degrading powergeometries and the floating boats, however small and distant they may seem, reflect Azure's exhilarated spirit, and become placeholders for his hopes. The peaceful beach scene, however, ends abruptly with the sudden appearance of "[t]hat black man", who, looking "like a bad man", brings back the threats of Cape Town's criminal underbelly. The 'Step-motherly City's' ambivalence is thus mirrored on a symbolic level in the beach and, by extension, the sea. Samuelson posits that in Thirteen Cents "[t]he sea is [...] ambivalently cast as source of danger, contamination and predation and of protection, purification and strength" ("Sea Changes" 20). Sea Point and its beaches indeed become a paradoxical place for Azure. Besides the rare moment of (peaceful) reflection quoted above, the sea functions as a veritable 'catching basin' for the evils Azure encounters in the 'Step-motherly City'. After a violent trick with a married man, for example, Azure takes a dip in one of the natural pools to ease his aching buttocks (Duiker, Thirteen Cents 5-6). At a later point, he recounts witnessing a woman giving birth at the beach and then throwing the new-born into the sea (142). Similarly, the beach, as a liminal space between the land and the sea, functions as both a place of inclusion and exclusion. Sea Point and its beaches, if one considers their geographical location, are both part of the city and at the same time removed from it. This geographical dis-location reflects Azure's place within the city of Cape Town and post-apartheid society. Azure is, and is not, from the city. While he is deeply ingrained in the city's (and 
post-apartheid society's) power-geometries, Azure's continuous perambulatory movements back and forth between the city centre Sea Point echo his 'afloat-ness' and, resembling the sea's tidal movements, bespeak his liminal status. Azure's roaming through Cape Town's streets can at the same time be seen as the reluctance on the part of the 'Step-motherly City' to take Azure in. By means of Azure's liminality, Duiker's novel thus swiftly weaves Sea Point's post-apartheid realities, i.e. its image of extremes as both "everymansland" (Sea Point Days) and crime hub, into the narrative.

Thirteen Cents clearly focuses on the latter, less favourable, and uncomfortable 'face' of South Africa's mad(dening) 'Mother/Step-motherly City'. It is, however, not only Cape Town's mad(dening) topography that afflicts Azure but also the city's mad(dening) topology, above all the continuing predominance of apartheid's 'colour scheme'. These 'colour matters', which Duiker's novel weaves into the narrative on a structural as well as more symbolic level, will be discussed in what follows.

\section{COLOUR MATTERS}

Of all the characters in Duiker's oeuvre, according to Viljoen, Azure is "the most clearly solitary and relentlessly individual character, who does not belong to any one place or to any social group, and who defies attempts to categorize him" ("K. Sello" vii). In view of his blue eyes and light skin complexion it can, to a certain degree, be claimed that Azure goes against apartheid's tripartite racial categorisation ('white', 'coloured', and 'black') since "he is none of them and at the same time all of them" (xi). While Azure himself, however, identifies as 'black' (Duiker, Thirteen Cents 35, 151-152), it is in the socioeconomic and -cultural norms of the novel's fictional(ised) (post-)apartheid setting that the protagonist's dilemma lies.

The divergence between Azure's misleading (coloured/white) physical appearance and his identification as black sends mixed signals. Azure's blue eyes contest his black subjectivity and make him 'stand out'. "I' $m$ used to people staring at me", he says on the novel's opening page (1). And yet, the attention Azure attracts reflects his troubled position and ingrained insecurity: "I can never look too long in the mirror as my blue eyes remind me of the confusing message they send out to people. I wear my blue eyes with fear because fear is deeper than shame", he admits (19). The colour blue, a symbol for both whiteness and Azure's fear and shame, reappears throughout the novel in many forms; the blue towel Azure is handed by one of his customers (9), the 
blue dress for patients given to him by the doctor at Somerset Hospital (42), his new name Blue (56), or the glittering, blue tracksuit pants Azure is to wear after his renaming (68). The colour blue involuntarily reminds one of the musical genres of Blues and Jazz. In his article, "Is Philosophy Blue?", Lewis R. Gordon stresses that black subjectivity is "a rejected sight of normative life in the modern world with the realisation of being indigenous to that world. [...] This contradiction raises a condition of blackness in the modern world, one that is nothing short of blue" (17). This contradictory, and negative (or negated) subject position found prominent expression in Blues (and Jazz). Gordon traces the origins of Blues to the expression 'blue devil' from the seventeenth century, which refers to the hallucinatory effects of grave alcohol withdrawal, and links this possible genesis to the colour blue and its connection to the light conditions at dusk, but also its relation to the regal (light blue) or to mourning (dark blue) in West African tradition. While the origins of the term Blues seem to be unclear, "[w]hat is clear", according to Gordon:

is that the blues emerged when these worlds, African and European, converged in the new world in conditions of misery whose reverberations echo to the present. This adds a dimension, perhaps psychoanalytical, to the European premise of a drunken after effect: the high of modern exploitation and profit wreaked the low of the morning hangover; reality always has its price. (17)

Both Azure's new name and the constant resurfacing of the colour blue can be seen as reflecting the negativity of Azure's subject position and an inscription of his shame and fear on his body. Within the (post-)apartheid context, it should be noted, feelings of shame and fear are typically ascribed to coloured subjectivity, particularly coloureds from the (Western) Cape. Classified as neither white nor black under the 1950 Population Registration Act, coloureds were left in the legal 'black hole' between "being the privileged black and the 'not quite white' person" (Erasmus, "Re-emagining" 14; see also Wicomb, "Shame" 101). The Black Consciousness Movement subsumed the coloureds under 'the fig-leaf of blackness', with the consequence that "[a]lthough coloured people could identify with the struggle against apartheid by rejecting their identity and identifying as black, they would still be 'blacks of a special type'" (Erasmus, "Re-emagining" 19). Coloureds were furthermore stigmatised as immoral, loose, impure, and deceitful, which involuntarily bound coloured subjectivity to a deep sense of shame (Erasmus, "Re-emagining" 17), and "the shameful vote of Cape coloureds for the National Party in the first democratic election" only added to it (Wicomb, "Shame" 93). Jointly, this re- 
sulted in coloured identity as lacking "an identity 'in its own right'" (Erasmus, "Re-emagining" 17). By means of Azure's 'misleading' (coloured) appearance, Duiker's novel thus ingeniously blurs the boundaries between (apartheid's) racial categories and transfers this fundamental element of coloured dis-ease to Azure's black subjectivity. It is not until Azure's dream encounter with Sara Baartman, whose case has become iconic for the embodiment of (coloured) shame (Wicomb, "Shame" 93), that he is able to overcome this aspect of shame, as I will argue in the last section.

At the same time, this notion of a seeming genetic entanglement is one of the sources of Azure's fearful and uncertain existence within the fictional(ised) post-apartheid city where his subjectivity clashes with the white normativity perpetuated 'top-down' by the 'play-whites' Allen and Gerald (Duiker, Thirteen Cents 35-36). Allen and Gerald can be said to be preserving the "collective unconscious" of South African whiteness during apartheid, i.e. "the unreflected imposition of [white] culture" on non-whites, to adopt Fanon's argument to the South African context. According to Fanon, it is not unusual for the black subject, or in Allen and Gerald's case the coloured subject, "to be anti-Negro. Through the collective unconscious [it] has taken over all the archetypes belonging to the European" (Black Skin 147). It is Allen and Gerald's envy of Azure's blue eyes - here symbolising South African whiteness (among other things) - that triggers their 'negrophobia', and here the argument yet again leads back to the concept of madness, or rather neurosis. Fanon defines phobia as "a neurosis characterized by the anxious fear of an object (in the broadest sense of anything outside the individual) or, by extension, of a situation" which provokes "both fear and revulsion" (Hesnard qtd. in Fanon, Black Skin 119). Allen and Gerald's 'negrophobia' thus gives expression to the mad(dening) legacy of apartheid's racial categories and their mad(dening) and compulsive application among non-whites.

This system of make-believe, however, is - at least initially - beyond Azure's grasp and needs explaining by his childhood friend Vincent. The following scene takes place after Azure has mistakenly called Gerald by the wrong name, a slip of tongue the latter considers a racial insult. Now, Azure is hiding from Gerald. Having bought himself a pair of veldskoene, characteristic footwear of Afrikaner farmers and thus a 'marker' of whiteness, Azure goes to see Vincent who advises him to call on Gerald and issues the following warning: 
'I know you're scared, bra, but just go. But take those shoes off. You know Gerald, he's fucked up. He thinks he's white because he's got straight hair and a light skin. If you show up with those shoes and your blue eyes, he'll kill you. He'll say, Who the fuck do you think you are? Trying to be white?'

'But I'm not.'

'I know that, bra. We come from Mshenguville together. I know that. But that asshole doesn't. He'd love to have your blue eyes. Everyone knows that except you. You must try and work around your blue eyes.'

'What do you mean?'

'I mean you have to be the blackest person.'

'But I am dark. Look at my skin. I'm not far from makwerekwere.'

'No, I mean you have to be more black ... like more black than all of us. You must watch what you wear. Like those shoes. Things like that give you away. [...]' (Duiker, Thirteen Cents 35)

It is difficult to digest the cruelty of Vincent's advice to "try and find a way around [his] blue eyes" and be "more black" than everyone around him due to its implication of a (partial) denial of his identity on Azure's part. This necessity, in turn, suggests an additional element of dis-location (an additional degree of 'alienation' and/or madness). Only in its further 'estranged' form Azure is already a new-comer, and thus a stranger, in Cape Town - closer to a makwerekwere (i.e. particularly a black foreigner from the continent), will Azure's subjectivity fit into the power-geometries of the 'Step-motherly City'. The necessity to be 'like' a foreigner, however, bears equal dangers of violence against the black subject, a danger that brings to mind the predicament at the core of the 2008 and 2015 xenophobic attacks. Referring to this, McKaiser argues that the South African blacks "have learned not to give due regard to the interests of foreign nationals" and instead "uncritically rank people from the region into categories of different levels of entitlement to respect, just like the apartheid government ranked [non-whites] with legislated arbitrary criteria" (Run Racist 207). McKaiser's argument can certainly be extended to Allen and Gerald whose arbitrary mistreatment of Azure prompts a comparison with the cruelty the black foreigners were met with during the xenophobic attacks.

'What does not fit is made to fit' indeed seems to be Gerald's streetwise credo. In one of the novel's most brutal parts Azure receives the punishment for his 'offence' against Gerald: 
[Sealy] punches me across the face. I fall down in utter shock.

'Sorry, I have to do this,' he says. '[Gerald]'s watching.'

He kicks me in the ribs as I'm about to get up. The sun is hot, hot.

'Get up,' he tells me.

I get up, holding my broken ribs. He punches me again with a strong left hook. I stagger and land on my face. He kicks me in the head and stamps on it, grinding me into the tar road. I start screaming and grab his leg. He fucks up my face with his fists. My nose starts bleeding and snot runs. 'Sealy, I'm sorry,' I beg. He continues hitting me. Eventually I let go of his leg and roll up into a ball to protect my head. He kicks my back and rips off my jacket. The music plays on. The sun beats. (38-39)

The fundamental perversions of the power-geometries at play in the novel are on full display in this scene. Fittingly, Gerald does not execute the punishment himself but delegates the task to Sealy so as not to 'dirty' his hands. The actual beating amounts to a literal degradation and 'adjustment' of Azure's ego as he falls to the floor only to be ordered to get up and be beaten down again.

This scene of violence is rock bottom for Azure whose "black sel[f]" is most literally "damaged" (McKaiser, Run Racist 199-211). He is brought to Somerset Hospital by Richard, another of Gerald's lackeys, where he looks at himself in the mirror and reports: "All I see is purple, red and a little blue staring back. My face is swollen. I can hardly tell that it's me looking back" (Duiker, Thirteen Cents 44). There are several salient aspects about Azure's observation. In comparison to the previously mentioned 'mirror scene' in which his blue eyes (and the fear and shame related to them) are the focus, there now is only "a little blue staring back". Azure has (brutally) been 'put in his place', his ego has been 'set straight'. The Azure from the beginning of the novel has (almost) disappeared. Moreover, the colours mentioned in the description (all three colours of the rainbow) amount to an unvarnished criticism of the 'rainbow nation'. With four out of seven rainbow colours missing, the 'rainbow nation' Azure lives in is a terribly flawed one. It is a dis-figured construct built on the premises of violence.

Azure's punishment furthermore re-establishes Gerald's dominance, and hence (the emulation of) white normativity. It is striking how this reestablishment is once more echoed in the recurring appearance of the colour white in the novel. At Somerset Hospital, Azure is brought to a "white room", is asked to sit down on a "white bed", and the "white doctor", who is wearing a "white coat", draws a "white curtain" before examining his patient (42-43). This contrast serves to highlight Azure's non-whiteness in the 'hyper-white' 
surrounding and, by implication, the binary halves of South Africa's racially loaded history. ${ }^{71}$ Richard, who accompanies Azure to the hospital, has no difficulties creating an excuse for Azure's injuries; he presents Azure as a juvenile delinquent and acts as his saviour. The grotesque scene reaches its climax when the white doctor unashamedly jumps on the bandwagon and explains to his nurse how Azure: "Ran away from home. They all do, you know. Wild kids. And now he's caught stealing a bar of chocolate or something pathetic like that. He deserves what he got" (43). Together, these examples amount to a veritable demonstration of white (South African) normativity and prejudice on a symbolic level. They are a symbolic endurance of "the sum of prejudices, myths, collective attitudes of a given group" (Fanon, Black Skin 145), here white South Africans and the copying of their 'ideals' by Gerald and his lackeys. The plaster (most likely white too) Azure receives for his "fractured ankle" (Duiker, Thirteen Cents 44) only adds to the symbolic showcasing of white normativity and speaks to the weighing down of Azure's ego by the fictional(ised) post-apartheid power-geometries.

In many ways, Azure's beating is the beginning of an extended phase of torture and humiliation. Torture, according to Elaine Scarry, is "a spectacle of power", "the production of a fantastic illusion of power", and "a grotesque piece of compensatory drama" $(27,28)$. Azure's beating indeed amounts to the spectacular, illusionary establishment of Gerald's power over Azure that compensates for Gerald's 'genetic lack' of whiteness. While the perpetuation of white normativity on the part of Gerald and Allen has been well established, there remains the question of what effect the act of torture, together with the infliction of physical pain, has on Azure. Scarry argues that for the tortured person "physical pain always mimes death and the infliction of physical pain is always a mock execution"; "[w]orld, self, and voice are lost, or nearly lost,

\footnotetext{
71 The scene is reminiscent of the moments leading up to the 'rape scene' in Mating Birds (169-178). Ndi Sibiya recalls how "the weather was magnificent that day. It was quite breathtaking to behold the dark nervous shimmer of sun upon the dark foliage - the pail air rising blond and dazzling as though a million needles were scattering through the air" (170). The weather establishes the black-and-white/darkness-and-light dichotomy that runs through the whole passage. Shortly thereafter, Sibiya becomes a "dark immobile figure leaning against the rickety gate, gazing at [Veronica]" who "was doing something with her hands; narrow, flowing, gleaming like polished copper in the intense daylight heat of the little room, her naked arms were raised and she was fumbling with pins in her hair, which was falling down in shining cascades over her smooth shoulders" (172). Veronica's actions anticipate her further undressing, which leaves her "naked [...] in the middle of her room in a mindless careless pose wrapped up in a shawl of light. She was like a burning flame [...]" (173). Similar to the hospital scene in Duiker's Thirteen Cents, the abundance of light serves to highlight Veronica's whiteness in opposition to Ndi Sibiya's blackness.
} 
through the intense pain of torture" $(31,35)$. The experience of torturer and tortured could thus not be more different: what is in the making for one is taken from the other (power and voice); what is unimportant for one is central to the experience of the other (the body and its physical pain) (35-36, 45-46). This certainly is the case for Azure whose "roll[ing] up into a ball" (Duiker, Thirteen Cents 39), even if as a reflex in an attempt to protect himself, reflects the 'debasement' and 'reduction' of Azure's power and self. Azure furthermore temporarily loses his power of speech, which is reduced to a mere "screaming" (39) because of the physical violence exercised on him. It takes a long time for Azure to 'recover' from this violent debasement and 'silencing'. During his whole captivity and his first encounter with Gerald afterwards (i.e. the remainder of chapter eight as well as chapters nine and the beginning of chapter ten), Azure's power of speech is, in fact, limited to two- or three-word responses.

There is another salient aspect of torture worth mentioning here. Scarry describes the importance of the torture room in the overall procedure of torture and shows how the positive symbolic function of the concept 'room' as a place of shelter and fortification of human life is 'undone' by means of its 'weaponisation' and incorporation in the process of inflicting physical pain, for example by hitting the prisoner with available pieces of furniture or by banging his/her head against the wall (38-45). This ambivalence of the (torture) room's symbolism, Scarry alerts, has been 'codified' in language where:

the protective, healing, expansive acts implicit in 'host' and 'hostel' and 'hospitable' and 'hospital' all converge back in 'hospes,' which in turn moves back to the root 'hos' meaning house, shelter, or refuge; but once back at 'hos,' its generosity can be undone by an alternative movement forward into 'hostis,' the source of 'hostility' and 'hostage' and 'host' - not the host that willfully abandons the ground of his power in acts of reciprocity and equality but the 'host' deprived of all ground, the host of the eucharist, the sacrificial victim. (45)

Scarry's observations shed new light on Azure's situation. The tension between hospitability and hostility, which becomes ostensible in the brief etymological overview, leads back to the novel's depiction of Cape Town discussed in the first section. Azure does not experience the 'Mother City' as a particularly hospitable place but rather a hostile place, which transforms Cape Town into a 'Step-motherly City' for him. This tension between hospitability and hostility is what I have called one of Cape Town's mad(dening) effects on Az- 
ure. ${ }^{72}$ In view of Scarry's reflections on the functioning of torture, there is, one can argue, an additional 'torturous' element to the city's mad(dening) mechanisms of exclusion/exclusivity and inclusion/inclusivity, an antagonism which is implied in the opposition of hospitability and hostility. Particularly Azure's exclusion from the city, paradoxically to include him (or 'make him fit') into Cape Town's pervert fictional(ised) power-geometries, is reflected in his first being locked up and then locked out by Gerald's lackeys (Duiker, Thirteen Cents 45-55). The antagonism between notions of hospitability and hostility are also reflected in the Foreshore Freeway Bridge, Gerald's base of operation, which is a symbol for the apparent perversions and imperfections of the novel's fictional(ised) version of the new South Africa. Ultimately, the aspects of hospitability and hostility discussed here are not so different from Simone's notion of (un)inhabitability mentioned at the beginning of my analysis.

Azure's ill-treatment and subsequent captivity may be a low point, but it can also be seen as a turning point. Locked up in an outside room of the house in Salt River he is brought to, ${ }^{73}$ Azure describes his recovery process: "For three days they don't open the room. I shit in a toilet bowl they left in the room for me. My bed is just a sponge. For three nights I listen to my wounds, my bruises. For three nights I feel my body healing" (Duiker, Thirteen Cents 46). Azure's use of language here is striking. The opposing personal pronouns 'they' and ' $\mathrm{I}$ /'my' establish a clear line between Azure and his captors, which once more also implies all the socio-economic and -cultural adversities Azure is faced with. The opposition is further corroborated by the temporal markers and the day/night-contrast they introduce as well as the separation of the temporal marker's first ("[f]or three days") from its second and third occurrence by two sentences ("[f]or three nights"). The threefold repetition initiates

\footnotetext{
72 This opposition reminds of Derrida's discussion of the concept of 'hospitality' in, for example, Of Hospitality. According to Derrida, the (European) logic of hospitality is characterised by the following antinomy: Hospitality should first and foremost be 'unlimited'. Hospitality should be an unconditional welcoming of a stranger without expecting anything in return. And yet, hospitality implicitly comes with certain political, legal, and moral 'conditions' according to which the foreigner's or stranger's right to remain is decided on. Asylum seekers, for example, are only 'welcome' if they fit a particular country's asylum laws. An asylum seeker's 'welcome' is furthermore 'time-restricted' and may be revoked should a particular condition not be met. Azure is indeed constantly confronted with this paradoxical contradiction of the concept.

73 The connotation of Salt River as a distinct place of 'colouredness' in Duiker's Thirteen Cents is very different from the neighbourhood's function in Maart's Rosa's District 6 where it is a "place of privilege" (see Chapter 1.2), which suggests a 'function change' of the neighbourhood from apartheid to post-apartheid.
} 
a rhythmical pattern that is to accompany Azure as his thoughts start to drift off into a 'dream space-time':

I'm getting stronger, I tell myself even though my stomach grumbles. When I start to feel weak, I sing. [...] I do that for a long time. I'm getting stronger, I tell myself again and feel my stomach muscles forming into hard ridges. Destroy, destroy, the music plays on in my head.

I lie on my back and stare at the light till I see half-circles of fire. Then I turn off the lights and destroy the room with half-circles of fire. A volcano rages in my head as I do this. When the fire starts fading I turn on the lights again and stare at the light. I do this for most of the night and sleep during the day. You're getting stronger, I tell myself and turn off the lights. I start to feed off the light and begin to slowly forget my hunger. Grown-ups, this is how they teach me to be strong. I take in their light and destroy them with fire. (46-47; my emphasis)

Even though it is involuntarily and forcefully imposed, Azure's captivity seems to have some positive effects on him. Azure's isolation, most of which he spends in a dreamlike state, 'affords' him the space and time to process his experiences and to regain his strength. ${ }^{74}$ The power Azure gains from the fire circles forebodes the novel's apocalyptic ending atop Table Mountain, as suggested by the triple repetition of the word "destroy". Both the theme of fire and destruction are central during Azure's time atop Table Mountain. Azure further imitates the rhythmical pattern established in the chapter's opening lines by repeatedly reassuring himself that he is "getting stronger". It is striking that Azure talks about himself both in the first and second person, a distinction that suggests an ego-split in the most Freudian sense. This split, however, does not indicate an opposition between the ego's critical abilities and the rest of the ego, but a 'return of the repressed' (Freud, "The Uncanny" 241). It is Azure's trauma related to the death of his parents that resurfaces here due to his physical mistreatment. That Azure has never (fully) dealt with this traumatic event becomes evident early on in the novel where Azure recalls: “My friend Bafana can't believe I saw my dead parents and didn't freak out. But I told him. I cried and then it was over. No one was going to take care of me" (Duiker, Thirteen Cents 2).

Freud, in "Beyond the Pleasure Principle", defines trauma as "excitations from outside which are powerful enough to break through the protective shield" of "an otherwise efficacious [mental] barrier against stimuli" (29). The

${ }^{74}$ See Demir who discusses Azure's singing as a source of strength during his captivity (167168). 
problem, according to Freud, then is for the psychic apparatus to handle this hyper-stimulation by pooling the stimuli in order to eradicate them (30). Irene Visser claims that the post-traumatic stage is, in fact, more relevant than the traumatic event itself and consequently posits that trauma "denotes the recurrence or repetition of the stressor even through memory, dreams, narrative and/or various symptoms known under the definition of Post-Traumatic Stress Disorder (PTSD)". Among the primary symptoms of PTSD, Visser enumerates "nightmares, flashbacks, depression, but also an increased sensitivity to cynicism, depersonalization, and distinct changes in spirituality or worldview" (272). Particularly the first and last symptom of this list will prove relevant in Azure's case, as I will show in the next section, and the topic of PTSD and its primary symptoms leads back to the aspect of mental illness and/or madness.

Ultimately, Azure's ego-split has to be seen as part of the 'coping mechanism' to deal with his trauma in imagining a 'comforting object', or rather 'comforting objectification' in the form of an 'alter-ego'. According to Scarry, such an act of imagination is "the ground of last resort. That is, should it happen that the world fails to provide an object, the imagination is there, almost as an emergency standby-basis, as a last resource for the generation of objects" (166). Since there is no one there to care for and comfort Azure, he assumes that role himself by addressing himself in the second person and becomes his own comforter. The ego-split, together with the 'dream space-time' in which he seeks refuge allows Azure to process the trauma inflicted on him. ${ }^{75}$

The element of 'self-comforting' resurfaces during the second phase of Azure's captivity on the roof of the dilapidated block of flats in which Richard lives: "Sshhh, I tell myself. You're getting stronger. You're getting stronger. I must repeat this to myself" (Duiker, Thirteen Cents 49; my emphasis). The third phrase follows considerably later, once Azure is locked out on the roof again after his gang rape: "I smile and close my eyes. I'm getting stronger, I whisper to myself before I fall asleep" (55; my emphasis). With this the rhythmical pattern is completed for a third time, thus bringing the circle to an end on a secondary level, too. The doubling of the second-person pronoun in this third instance of the repetition, which is reminiscent of Freud's concept of the 'uncan-

75 There are a number of studies on trauma, particularly in relation to the Truth and Reconciliation Commission (TRC) and its aftermath (see e.g. Gobodo-Madikizela and van der Merwe; Graham; Mengel and Borzaga; Samuelson, Remembering; Singh and Chetty). It would, however, go beyond the scope of this study to discuss the aforementioned studies in depth. Suffice it to say that trauma and mental illness (or madness) are closely related and that there is room for further research at the intersection of the two concepts. 
ny' and reflects the aspect of trauma on a narratological level, speaks to an intensification of Azure's ego-split by which he distances the traumatic experiences from his self/himself. This distancing process is reflected in the gradually increasing (narrative) space-time that is needed until the tripartite pattern is completed. The return to the first-person pronoun back on the roof, in turn, can be seen as Azure's recovery of his mental balance. As Azure drifts in and out of the 'dream space-time' (established during his captivity) during the remainder of the novel, the phrase resurfaces over and over and becomes a mantra of sorts in order to help Azure not to lose his mental balance (again). ${ }^{76}$

During his captivity, and in particular his time locked out on the roof, Azure seems to come to terms with himself and the world. Observing how some seagulls attack a flock of pigeons gathered on the roof, Azure notes:

They are beautiful seagulls. They have white feathers that they look after and you never see a seagull that looks battered with dirty wings like some pigeons. Seagulls have pride, they always wash at sea with cold water. Like me. I watched the seagulls a lot when I first came to Cape Town. (51)

It is striking how Azure contrasts the "beautiful seagulls" and their "white feathers" with the "battered" pigeons with "dirty wings" and aligns himself with the former. The pride Azure sees in the seagulls becomes a token for the pride he re-gains during this period of his captivity. This becomes even more evident in the following extract:

When I look out I see seagulls perched out on the edge of the roof. They stand there like statues till one of them opens his wings and drops onto the warm roof. It's a man seagull. You can tell from the way he walks. The others stand there and wait. I also stand at the door and wait. He waddles towards me and stops about a kick away. Then he shits there and flies back to the others. Without thinking I walk over and put my finger in the mess. I scribble a cross on the door with it. Then I walk to the mess and piss in it. I go back to the wall and sit. (54-55)

The bird's decision to do "his" business close to Azure, on the one hand, is akin to all the negative experiences Azure has had up to that point in the novel, particularly all the use of violence against him by Gerald and his lackeys. Azure's reaction, on the other, amounts to a decision on his part to re-gain his agency. By "put[ting his] finger in the mess" and "scribbl[ing] a cross on the

76 The two phrases and their variations appear on pages $46-47,49,54-55,67,71,89,90,99$, 103, and 104. 
door with it", Azure marks his space/place within the 'Step-motherly City' and lays down a marker against Gerald. Azure's action, in connection to his 'elevated' position on a building's roof, which, once again, anticipates Azure's time and actions atop Table Mountain, is at the same time indicative of an 'initial ignition' in overcoming the city's power-geometries. ${ }^{77}$

The fundamental change in Azure becomes apparent when he returns to the shop in Long Street where he bought the veldskoene, to buy himself a new jacket: "I find a jacket that fits me. A black bomber jacket. And the price is right. It says seventy-five. But it worries me because it's orange on the inside and Gerald said I mustn't wear that colour. But I feel a little dangerous as Vincent has left and decide to buy it" (99). Azure's decision to buy the jacket despite Gerald's prohibition to wear anything orange (68) has a twofold function. On the one hand, it is a (first) sign of Azure's pride in his black subjectivity. On the other, it is tantamount to his resolution to 'give Gerald the finger' and to overcome Cape Town's white normativity as he ignores Gerald's prohibition and thus the marker of the latter's superiority over Azure as well as his frantic need to maintain white normativity by 'playing-white'. The symbolic final 'cord clamping' of Azure's submission to the perpetuation of these perverted power-geometries, happens when Gerald, in reaction to Azure's purchase, remove's Azure's cast and chases him away. Here part of Azure's account of his flight:

'Now foetsek, jou poes!' He kicks me. I run away till I get to the main road. My head is spinning with confusion. Surprisingly my ankle doesn't hurt. I take off my shoe and hold it. I walk fast and don't think about where I'm going. I just walk. I go into town and walk into the Gardens. I throw my shoe into a bin. My heart is racing, I keep on walking, looking behind me to see if Gerald is there. (102)

Liberated from the last token of the city's white normativity, Azure starts his first ascent to Table Mountain (see Figure 10).

\footnotetext{
77 See Demir who similarly reads Azure's gang rape as "an ambiguous symbol of resistance and self-empowerment in a moment of loss" and argues that "[t]he seagulls, a sign of resistance and strength, point to Azure's capability of resilience in a moment of loss" (169).
} 


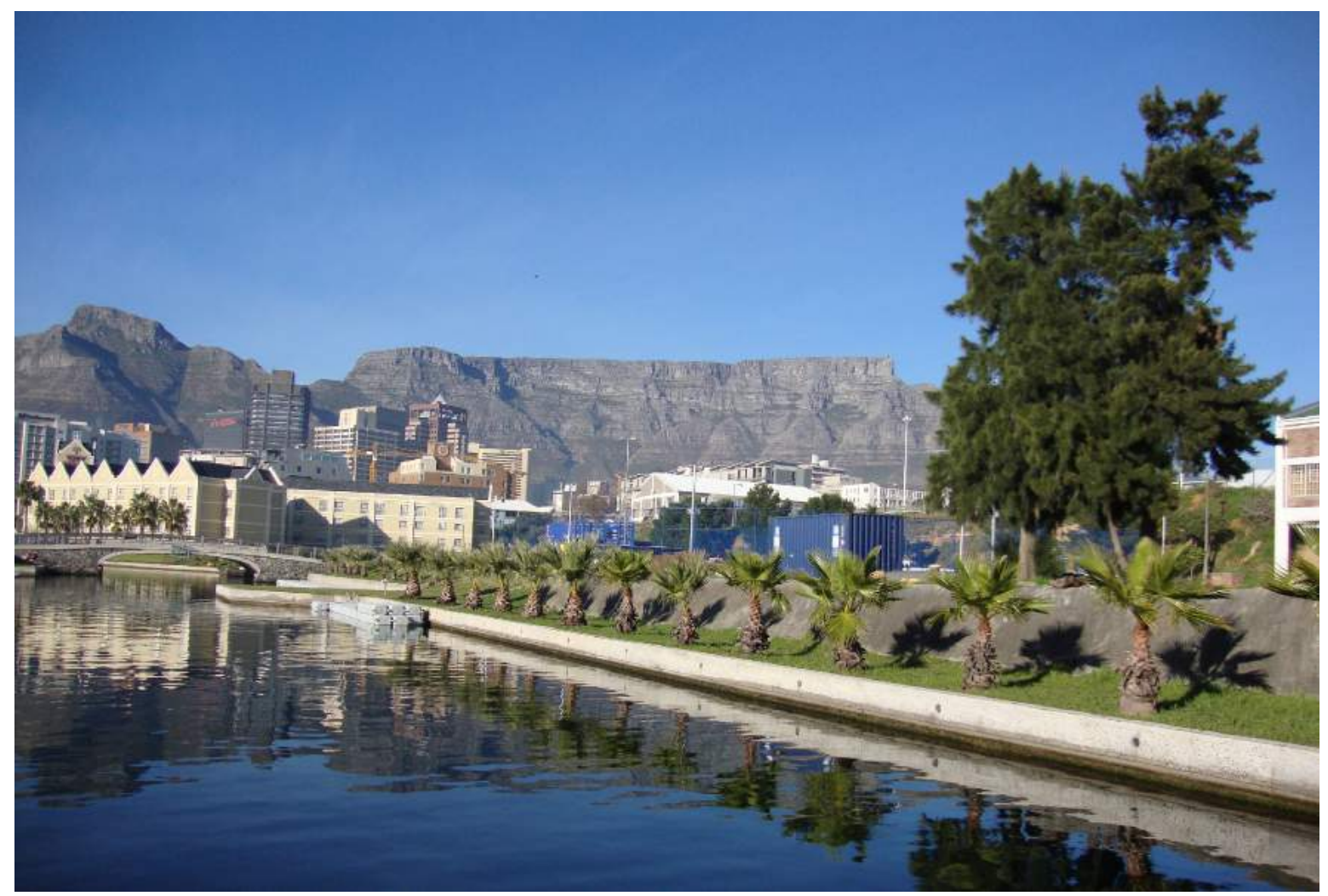

Figure 10: View of Table Mountain and Devil's Peak from V\&A Waterfront.

\section{WALKING 'TOWARDS THE LIGHT'}

The title of this last section is a piece of advice Vincent gives Azure - "Just remember, if you're ever in trouble go towards the light" (97) - a counsel Azure remembers and repeats on his ascent to Table Mountain (105). It is with Azure's walk up Table Mountain that reality and imagination start to increasingly blur as he re-enters his 'dream/hallucinatory space-time':

Destroy, destroy, my feet burn as I walk on the hot tar and pavement. Whenever I can I walk in the shade. But I keep the pace fast, no matter if there is sun or shade. I just keep walking. [...] Destroy them, I hear my feet say as sharp stones punish my feet. I walk and keep shaking my ankle once in a while. I'm stronger, I tell myself. (103; my emphasis)

With Azure's ascent to Table Mountain, the novel's (or rather Azure's) tone becomes angrier and more determined. The focus is no longer on the comforting refrain, which here appears in the affirmative variation "I'm stronger", but on Azure's wish to "destroy". The latter, in analogy to Azure's growing will and physical strength, becomes ever stronger the higher he climbs. At the same time, the returning rhythmical pattern of threefold word repetitions goes 
hand in hand with the change of pace at this point in the novel. Subsequently, the three recurring themes of strength, destruction, and fire alluded to in these word repetitions, all three of which originate from Azure's time in captivity (see above), increasingly overlap. This overlap, in turn, bespeaks the increasing blur between the fictional(ised) reality and Azure's 'dream/hallucinatory space-time'. I deliberately add the second adjective 'hallucinatory' here to account for the alternation between the dreams (or rather nightmares) and hallucinations - i.e. the perception of something that is not actually present (American Psychiatric Association 87) - that Azure has atop Table Mountain.

At times, Azure's renewed mental drift is very poetic:

The madness is inside me. The sun burns hot. Lizards crawl in my path. I go up further, the rocks tearing at me. I come across a dog and its owner. [...] I suck my teeth and he sees the madness in my eyes. [...] You must climb higher. Higher. I finish drinking and look at the sun. I stare at it with open eyes and feel the energy going through me. It mingles with the zol in my head and gives me fire. I get to the part where there is only shade. My body cools down but I don't slow down. Fire! Fire! I must give them fire, I tell myself. Higher. (Duiker, Thirteen Cents 105; my emphasis)

Azure's driftage may be cannabis-induced (104). This would account for the hallucinations, a typical symptom of a (cannabis-induced) psychosis (American Psychiatric Association 89). This loss of touch with reality, which reflects Azure's socio-political and -economic alienation, distinguishes Azure from the neurotic Johan van Wyk in Man Bitch. Azure's re-immersion into his 'dream/hallucinatory space-time', however, passes beyond its protective function at this point. The word repetitions in fact link back to the musical genre of the Blues (and Jazz), where repetition is central. According to Gordon, repetition in Blues (and Jazz) "reveal[s] new layers of meaning about the cyclicality of life" as "[t]he blues agent [...] takes responsibility for her or his existence, and in doing so can also transcend its conceptual framework in flights of imagination" (19). In Azure's case, this transcendence is invigorated by the various word repetitions, which seem amplified here by the rhyme. It is as if the rhyming word repetitions of "higher" and "fire" propel Azure to top physical performance. Always doubled, except for the last "higher", the word repetitions not only speak to Azure's determination but also imitate the accelerating pace at which he walks. Azure seems to be fully immersed his 'dream/hallucinatory space-time', so much so that " $t$ ] he madness is inside 
[him]" (Duiker, Thirteen Cents 105), the madness thus becoming Azure's 'flight of imagination' (Gordon 19).

As an aside, it is worth mentioning that Azure's phrase reappears in the article Duiker wrote for the Rhodes Journalism Review. Commenting on the imposed curfews of, and regular raids by, the apartheid regime in the late eighties, Duiker asks: "Where did one go for refuge? Where did you go to keep your dreams alive, to re-awaken a sense of well-being when there was so much despair?" and explains in response to his questions:

My own natural reaction was to read as much as I could. It was the only way to survive: it offered me a form of escape. I felt I had to learn to articulate the disturbing silence that was being forced upon all of us - a state of being which I called 'The Madness'. There was no information coming from the regime about what was happening in the country, so I had to make sense of things in my own way. ("The Streets" 8; my emphasis)

Even though it is not my intention to give an autobiographical reading of Thirteen Cents, the parallels between Duiker's autobiographical account and Azure's situation in Thirteen Cents are apparent. Similar to "the disturbing silence" that bore down on Duiker during his youth, Azure has no plausible explanation for his continuous misfortune. While in Duiker's case " $t]$ he madness" refers to (the space-time of) the apartheid regime and the inexplicable power-geometries in place at the time, the concept is transposed into (the space-time of) post-apartheid in Duiker's novel. Madness thus becomes Duiker's version of what Derek Hook calls (post)apartheid nachträglichkeit, i.e. the backwash or after-effects of apartheid in post-apartheid South Africa (186). Just as Duiker "had to make sense of things", consequently becoming an avid reader and eventually a writer in order "to find a voice; [his] voice" ("The Streets" 8), Azure is driven into action at this point in the novel. It is atop Table Mountain that Azure finds his form of expression, his 'voice', and is able to project and overcome his anger against the fictional(ised) power-geometries of post-apartheid South Africa and their continuous white normativity.

Once Azure reaches the top of the mountain, he finds a cave to sleep in and starts collecting firewood in a mad(dening) frenzy:

I shake out my ankle and think of Gerald. He thought he was going to destroy me. I'll give him fire. I'll give him destruction. I'll give them all destruction, I say and start gathering wood. I take the dead ones, the ones that look grey and white from too much drying in the sun. They will burn easily, I say, and leave the brown ones. It is hard work carrying them up and down and through the 
tunnel but I enjoy it. I work silently. For the first time I work like I know what I'm doing. I don't think too much. I choose wisely. That one will do. No, that one is still green. No, that one is heavy. That one is light. That one looks like a snake. That one looks like a leg. I pick the ones I like, the ones that look like something. I carry back arms, legs, bodies, birds, elephants, monsters with many arms and legs and other things. I even see one that looks like a head with a long neck. I pile them outside the cave. (Duiker, Thirteen Cents 107-108)

The passage clearly highlights Azure's need and eagerness to take action, an element that is reflected in the triple repetition of "I'll give him/them fire/destruction". It is furthermore remarkable how the act of collecting firewood turns into an action that reverses the 'colour scheme' that Azure is previously exposed to. He carefully handpicks the "grey and white" pieces of wood and consciously spares "the brown ones". The different body parts, animals, and monsters he collects and puts on a heap in front of the cave become placeholders for Azure's anger and pain. With the incineration of the wood Azure symbolically takes revenge for his misfortune:

I add more branches. The fire picks up. Feed me. Feed me, it says begging me for total destruction. I bring a monster with many arms and legs. I break off its limbs and throw them into the fire. They burn and the skin peels. When I throw the rest of the monster the fire jumps a little and makes a hissing noise like it's watching me. I watch the flames play with all the colours of the rainbow. But I like orange best. I like the burning embers underneath. The more I watch the fire, the more I feel like dancing. I take off my jacket and put it in the corner. It will be my bed. Then I start slapping my thighs like a drum. My back straightens and I close my eyes. The smoke fills my head. The fire makes me sweat. $(110-111)$

Azure is in power here and the burning of the "monster with many arms and legs" turns the scene into a (symbolic) 'reverse torture'. The monster's figurative dismembering re-enacts both Azure's physical abuse by Gerald, Sealy, and Richard as well as his dis-location and/or alienation within postapartheid society. Just as Azure was 'handed around' among Gerald and his lackeys, the wooden monster is now similarly dis-carded and thrown onto the fire to be devoured by it. Azure's act of revenge, however, goes further than a simple reversal of the previously perpetuated 'colour scheme'. Interestingly, the wood's incineration re-enacts the black-and-white contrast of South Africa's (post-)apartheid society as Azure "watch[es] the flames play with all the colours of the rainbow". Thrown onto the fire, the monster's limbs catch fire 
"and the skin peels". At that point, the previously "grey and white" (107) wood will first become black before turning into orange "burning embers" (110). What Azure identifies with here, I would argue, is the fire's heat, which will be at its highest when the embers glow, and the power he has over the fire. For once, Azure is at the top of the food chain and holds the power over the colour orange, which stereotypically represents (Afrikaner) whiteness and white normativity throughout the novel. Ultimately, the fire represents the surmounting of (post-)apartheid society's 'colour scheme'. Once the fire dies down what is left are the ashes which are neither black nor white but grey, a mixture of the opposing ends of the 'colour scheme'.

The fire, however, is not only Azure's equally forceful response to the violence he has suffered throughout the novel. With his mind at ease after the symbolic conquest of (post-)apartheid's racial categories, the fire allows him to re-connect with his black cultural roots. Azure reports how watching the fire makes him "feel like dancing" and how he "start[s] slapping [his] thighs like a drum", eventually drifting off into a vision of "a grey wolf running in the moonlight" who then transforms into a "big bird that spreads itself across the sky" (111). Azure's desire to dance, which he fully acts upon during his second stay atop Table Mountain (157-158), allows him to 'tap into' autochthonous mythologies and is key to unleashing the fire's more ritualistic and spiritual function. The fire's ritualistic and spiritual function at the same time endow Azure's mad(dening) actions and behaviour during such moments, or phases, of hallucinations with more positivity and creativity. Veit-Wild, in her analysis of madness in literary and other cultural texts in Southern Africa, demonstrates how the concept of madness is linked to rituals and ritual studies. Rituals, such as processes of initiation for example, are typically (religious) ceremonies that reinforce an individual's link to, and position within, society. During these ceremonies, however, that very relation is temporarily destabilised, even suspended. For the duration of the ritual, the individual is in a 'space of transition' that is no longer the 'old' but not yet the 'new' (110). Making recourse to the ritual theories of the renowned anthropologists Victor Turner and Mary Douglas, Veit-Wild thus argues that "stages of liminality have the potential of destabilising the social order, they also contain an element of madness"; as "a borderline state", madness can correspondingly be seen as (part of) "the element of liminality, of being in-between" (3). If looked at against the backdrop of ritual studies, as suggested by Veit-Wild, Azure's mad(dening) 'dancing' is not just a re-connecting with his cultural roots, but can also be seen as his re-initiation to his black roots and ultimately his re- 
birth, even under violent premises, and thus the re-birth of the black subject into post-apartheid South Africa.

The spiritual equanimity that the fire bestows Azure with, I would argue, is also what leads to Saartjie's appearance in Azure's dream, doubtlessly Azure's most important encounter atop Table Mountain. The character of Saartjie is an allusion to Sara Baartman..$^{78}$ Sara Baartman was Khoisan woman who was showcased as the 'Hottentot Venus' at fairs, freak shows, and private functions in Europe and eventually caught the interest of scientists. In a posthumous examination of her body her genitalia and brain were removed and preserved and a plaster cast of her body was made (Beukes, Maverick 32). ${ }^{79}$

Azure repeatedly dreams of Saartjie during his first stay atop Table Mountain. Through these dreams Azure learns about his relation to Saartjie, who becomes "a kind of ancient mother" to him (Munro 205), T-Rex, whom Saartjie claims to be her husband and Azure's father, and the Mantis god, Saartjie's father (Duiker, Thirteen Cents 121-122, 126). Azure's "private mythology and chain of being", as Viljoen claims, can indeed be seen as "creat[ing] a new genealogy for himself to restore his dead mother and father" ("K. Sello" xvi). In light of the role the Mantis god has in South(ern) African mythology, however, there is more to Azure's "private mythology" than a mere 'imagined restoration' of his family. In Bushman mythology, the Mantis is part of the creation myth. According to the legend, the Mantis is the father of the first Bushman. He is carried to earth by a bee who, tired from its strenuous task, leaves the Mantis on a big flower. Before flying off and dying, the bee implants a seed in the Mantis from which the first Bushman is born. Besides its etiological function within Bushman mythology, the Mantis is also the bearer of fire. He steals the fire from the Ostrich and gives it to humanity who, thanks to this gift, henceforth is able to cook its food instead of eating it raw and has light at night (P. Miller 28). Both elements of Bushman mythology find their way into the novel. Similar to the original Bushman myth, the Mantis is the origin of Azure's 'imaginary genealogy'. The element of theft, in turn, is reimagined in that Mantis is said to have stolen the sun instead of the fire and this theft is linked to the etiological element in the sun's re-creation by Azure. Once he grows tired of Saartjie in his dream, he gets up and goes for a pee. He recalls: "When I pee my water is bright yellow and starts shining and becom-

\footnotetext{
78 This connection has already been suggested by Demir (159-161); Munro (204); Viljoen (“K. Sello" xvi).

${ }^{79}$ For further discussion of Sara Baartman and her cultural importance for coloured subjectivity see e.g. Buikema, Samuelson, Remembering (85-118), or Wicomb, "Shame".
} 
ing fire. I pee for such a long time that my bright yellow water becomes the sun" (Duiker, Thirteen Cents 129). The importance of the etiological element is further corroborated by the fact that shortly before Azure recollects:

in my dream, I take out a small bone from her [i.e. Saartjie's] ribs. I use it to take out the maggots under her breast. Then I sew up her wound with some string. I tie another piece of string to the bone and hang it under the tree. We sit and watch maggots crowding round the bone. They become so many that we have to move from under the tree. We sit near the rocks and watch the reflection of the sky in the still water. (127)

It is striking how the one Christian myth of origin in which Eve is created from one of Adam's ribs (Authorized King James Bible, Genesis 2:21-2:23) is reimagined by Azure in his dream. In the form of Saartie as the mother figure in Azure's 'imagined genealogy' and her rib, the passage, in fact, opposes autochthonous mythical elements with Christian elements. The rib is not so much used to create another being but to remove "the maggots under the breast" (Duiker, Thirteen Cents 127). The maggots, a symbol for dis-ease and rottenness, become a placeholder for the white/European mythology, which has corrupted the autochthonous ontology. The "crowding" maggots seem like an eerie caricature of (South) Africa's colonisation by the Europeans, and Azure's removal of the maggots amounts to a removal of any aspect of whiteness and white normativity from Saartjie and, by implication, from himself. The sowing of the wound becomes the first step towards a healing and reempowerment of the black subject more generally.

In view of their predominant etiological elements it can be said that Azure's dreams of Saartjie suggest clear alterations in his view of the world, one of the chief symptoms of PTSD (I. Visser 272). Even though my focus on the various etiological elements may have given the impression that Azure's dreams are of a peaceful nature, this is not the case. On the contrary, Azure for example follows a "blood path" climbing up Table Mountain in his dream and later on watches T-Rex "chewing people" and "destroying the City" (Duiker, Thirteen Cents 119, 121). These two short examples suffice to argue that Azure's dreams are, in fact, nightmares, a second primary symptom of PTSD (I. Visser 272). In their combination, however, the two symptoms suggest the possibility of a more positive reading of Azure's PTSD as well as his (cannabis-induced) hallucinations.

Such a positive and creative take on Azure's madness is corroborated by the fact that he recognizes the madness of the city and its people upon his re- 
turn from Table Mountain. Meeting Sealy, who tells him about Gerald's death, Azure realises:

I don't trust them. Grown-ups are full of words. But they never tell you everything. [...] They are full of shit, grown-ups. Their minds are rotten with all their poisons. I know Sealy also smokes buttons. He is mad. He says he is doing it in the name of love. What must I do with that? Must I believe him? He is crazy. They're all crazy. They think they are God. They think they know it all - the score. (Duiker, Thirteen Cents 140-141)

Azure's 'dream/hallucinatory space-time' has thus allowed him to see Cape Town and its people for what they 'really' are. Realising that now that Gerald is gone, Sealy is about to assume his position of power, Azure seems to recognise the mad(dening) perversion of Cape Town's power-geometries. All Azure wants is "to be left alone" and "to be able to walk the streets the way [he] like[s]", but Azure also understands that "[t]hey are never satisfied. I don't really remember a grown-up ever saying enough. They always want more. Even if that more means you have to work until you die" (143). Even though Thirteen Cents seems to be "strangely detached", as Timothy Johns argues with regard to the novel's lack of contextualising details that would allow a more precise (spatio-)temporal pinpointing (253), this is probably the most astute and direct criticism of post-apartheid mad(dening) economy and the mad(dening) laws of capitalism on Azure's part. Azure stays with Sealy for some time after his descent from Table Mountain. The removal of the people from under Foreshore Freeway Bridge and the subsequent destruction of the shacks are, however, the last straws for Azure: "The next morning four lorries come in. They wake up everyone and tell us that we are moving. They start taking apart shacks. The women scream and shout and swear. It takes about two hours for them to pack our belongings into the lorries. A bulldozer follows behind" (Duiker, Thirteen Cents 153). The removal is both an uncanny reminder of the forced removals under the Group Areas Act during apartheid as well as an eerie harbinger of the area's actual uninhabitability since the city has installed stone grids underneath the Foreshore Freeway Bridge in 2013 to prevent street people from sleeping there (Earnest). This event is at the same time the trigger for Azure's second ascent to Table Mountain.

The tempestuous conditions (Duiker, Thirteen Cents 154-155) under which Azure re-climbs Table Mountain herald the start of the novel's apocalyptic ending. Azure's second ascent to Table Mountain is, however, more than a mere running away from the city's madness. It is worth noting the re- 
surfacing of Azure's mantra in yet another variation - "You're getting closer" and "You're going to be fine" (155) - on his way up to the top. Azure thus temporarily shifts into the function of being his own comforter again. Seeking shelter from the roaring storm, Azure enters a cave, strips naked, makes another fire, and starts to dance to keep warm (156-157). He drifts into a trancelike/hallucinatory state and keeps "danc[ing] till [he's] so exhausted that [he] collapse[s] on the ground" (158). The incident is more than a mere "improvised [ritual]" that allows Azure "to tap into some cosmic power" as Munro suggests (206). After his trance, Azure feels that "the madness has left" (Duiker, Thirteen Cents 158). Both the stripping off of his clothes as well as the dancing can thus be seen as Azure's symbolic 'discarding' of all the burdens from his past. The scene "bring[s] about a newly recovered balance" (VeitWild 110), a typical outcome of a 'rite of passage'. Azure reports:

When I start to feel hungry I take ashes from the edge of the fire and draw shapes on my body. I draw a circle on my chest and give it arms and legs like it is a ball of fire that can move. I draw under my eyes and down my cheeks. A strange feeling fills me. I feel like I've done this before. When I look at the drawings on the wall I just know that whoever drew them used their fingers. They used branches and feathers and other soft things to touch. (Duiker, Thirteen Cents 158-159)

Azure's instant understanding of the rock paintings and what he is to do to apply his 'war paint' suggest that his cultural knowledge is innate. Once the war paint is completed, Azure has fully connected with his cultural roots. It is striking how this cave on Table Mountain, very removed from Sea Point and Green Point and the city's mad(dening) power-geometries, allows Azure to make use of his potential. He now seems to have gained worth, to be strengthened, at ease, and ready for whatever is to come. This stands in stark contrast to his previous devaluation. At one point Azure's 'value' is reduced to the mere "thirteen cents" that he has left in his pocket (132), an amount that, according to Viljoen, reflects "the commodification and commercialization" as well as "the destructive forces in Azure's world" ("K. Sello" x) and lends the novel its title. 
In the cave, which functions as a 'constructive womb' of sorts, 80 the positivity and creativity of Azure's mad(dening) ritual are at their height (Veit-Wild 3). Exhausted from all the physical exertion from his ascent to Table Mountain and his mad(dening) dance, Azure drifts off into the novel's final hallucination:

A huge wave rolls in. I stand up as it is the biggest wave I have ever seen. It gathers strength and moves quickly. I hold my breath and watch it tearing across the water. The sun shines in spots on the sea but on the mountain top it is calm and sunny. The huge wave crashes into the beach and floods the street. Another wave comes rolling in the distance. It looks bigger than the one before and moves at a faster speed. Faster, faster, I say to myself as I watch this trick. I dig my toes into the rock as the wave crashes onto the road and nearby flats. Cars get washed away.

[...]

And then the sky opens up. I stop running as the water is safely behind me and watch dark clouds coming apart. I stand on a rock and chase away some lizards. Above me the sun shines like the ruler it is. It dominates the sky with light. A ball of fire comes from it. It splits into smaller balls as it comes tumbling down at a mad speed. I crawl under a fallen rock and see balls of fire falling around me like blazing razors. Even though plants are wet from yesterday's rains they still catch fire. Animals run for shelter. I hear boulders crushing everything, branches snapping like twigs. In the distance I hear the agonising screaming of people being burned. The sky rains with fire. (Duiker, Thirteen Cents 161, 163)

In Azure's apocalyptic vision, "[l]and and sea are drawn together" and "Table Mountain returns to its prior state as 'Hoerikwaggo' ('Sea-Mountain')", as Samuelson rightly posits ("Sea Changes" 20). The two opposing elements of fire and water evoke the contrast of indigenous histories (the fire on land) and histories of colonisation (the sea) respectively. In light of "the sky open[ing] up" and the subsequent total destruction of the city by the rain of fire (Duiker,

\footnotetext{
80 It is beyond the scope of this thesis, but one could think of links to Julia Kristeva's concept of 'abjection'. To condense, Kristeva argues that there are certain things that are compartmentalised in the space between the subject and object (between the self and the other). These things, which used to be part of the subject but have been rejected since, are called 'abjects'. According to Kristeva, the mother is one of the things an individual abjects in order to construct his/her identity which she describes as "a violent, clumsy breaking away, with the constant risk of falling back under the sway of a power as securing as it is stifling" (13). Azure's time atop Table Mountain could be seen as his abjection of the 'Step-motherly City' (by finding shelter in another 'womb', i.e. the cave) and thus the initiation of Azure's independent subjectivity formation.
} 
Thirteen Cents 163), colonisation is symbolically and mentally overcome. With the victory, "the sea as surface over which [colonial] history advance[d]" (Samuelson, "Sea Changes" 11) is rejected and its function as a symbol of life, revitalisation, and a new beginning is re-established (P. Miller 28).

Ultimately, the apocalypse becomes a moment of catharsis that is needed in order to start something new. In its tabula rasa principle, the apocalypse becomes a means for Azure to leave Cape Town's madness behind and reach "the light" (Duiker, Thirteen Cents 97), to come to peace and be at ease with his black subjectivity. In this sense, the apocalypse becomes a continuation of Azure's 'rite of (re-)initiation' in the cave into a 'purification' of Azure's subjectivity which is ridded of its dependence on Gerald and his lackeys and their mad(dening) perpetuation of white normativity. The scope of Azure's newly won (mental) liberty becomes clear in the novel's closing lines: "when I let go, I open my eyes. I have seen the centre of darkness. I have seen the slave-driver of darkness and he is a mad bastard. I know his secrets. I know what he does when he sleeps. My mother is dead. My father is dead" (164). Azure's last words cannot only be seen as an acceptance of losing his parents, but it also shows a clear development in Azure's personality. One might say that by the end of the novel Azure also sees through the mad(dening) perversion of Cape Town's (post-)apartheid power-geometries and is thus able and ready to (mentally) relinquish them.

With its distinctly apocalyptic/dystopian ending, one might see Duiker's novel as an early precursor of a genre which has been growing in popularity in recent South African literature, as I have argued in the first half of this chapter. Duiker's novel ties in with the genre's typical preoccupation of racialised fear and whiteness in post-apartheid South Africa (Titlestad 30; Thurman, "Apocalypse Whenever" 60), even if from a distinctly black perspective. Like other apocalyptic/dystopian texts, ${ }^{81}$ the novel deals with the country's racially burdened history and is an attempt to overcome racial preconceptions. The novel's prevalent brutality seems to show how difficult and violent the process of reaching such a non-racialist ideal is. This seems to be corroborated by the fact that Azure needs two ascents to Table Mountain, once more a 'doubling' in the most Freudian sense, to be successful in his (mental) liberation from Cape Town's mad(dening) post-apartheid 'realities'. His ultimate success, however, can be seen as a beacon of hope among all the apocalyptic destruction.

${ }^{81}$ For a discussion of Charlie Human's Apocalypse Now Now and Kill Baxter see, for example, Moreillon and Muller. 
Azure's trajectory thus seems to be more hopeful than Johan van Wyk's in Man Bitch. In contrast to Johan van Wyk, Azure could be said to enter a "process of coming alive, of apprehending difference and a certain in-between space not wholly defined by what it 'transitions' from, or to", a definition Carol Long suggests for "a society in transition" (62). Azure's entering into a (mental) space-time of transition is inextricably linked to his relinquishing of past traumatic experiences, above all his parents' death. Freud, in "Morning and Melancholia", distinguishes two forms of longing: morning and melancholia. The two conditions share many characteristics such as a negative perception of, and disinterest in, the world at large. According to Freud, however, "melancholia is [...] related to an unconscious loss of a love-object, in contradistinction to mourning, in which there is nothing unconscious about the loss" (245). Furthermore, while the mourner is able to renounce the lost love-object, the melancholic clings to it, and the latter's inability leads to "a pathological disposition" that results in "a lowering of the self-regarding feelings to a degree that finds utterance in self-reproaches and self-revilings, and culminates in a delusional expectation of punishment" $(243,244)$. The novel's final sentences - "My mother is dead. My father is dead." (Duiker, Thirteen Cents 164) bespeak Azure's ability to 'let go' his lost love-objects, i.e. his parents' and his need for an ersatz figure, and thus to enter a space of transition where his black subjectivity gains (self-)worth. Johan van Wyk in Man Bitch, however, seems to be unable to overcome the death of his girlfriend Mbali and his subsequent love interests seem to be mere substitutes or 'removable films' for this lost love-object which, in turn, ultimately becomes an expression for van Wyk's white anxiety and his inability to find his place within post-apartheid South Africa. And yet, Long rightly suggests that "the act of telling our stories has the potential to enter transitionality, paradox and play" (61). It is in this sense that Man Bitch is an important addition to post-apartheid South Africa's racial discourses, despite - or probably precisely because of - its racially problematic premises. 


\section{CHAPTER 3: USTOPIAN Places}

As I was walking, one hot summer afternoon, through the deserted streets of a provincial town in Italy which was unknown to me, I found myself in a quarter whose character I could not long remain in doubt. Nothing but painted women were to be seen at the windows of the small houses, and I hastened to leave the narrow street at the next turning. But after having wandered about for a time without enquiring my way, I suddenly found myself back in the same street, where my presence was now beginning to excite attention. I hurried away once more, only to arrive by another détour at the same place yet a third time. Now, however, a feeling overcame me which I can only describe as uncanny, and I was glad enough to find myself back at the piazza I had left a short while before, without any further voyages of discovery.

- Sigmund Freud, “The Uncanny". (237; original emphasis)

Hyperreality.

The inability to differentiate. To distinguish.

Reality.. From a simulation - An imitation.

Hyperreality.

What is real? And what is fiction?

Hyperreality is the space where both collide.

Making it impossible to know where one ends. And the other begins.

That is hyperreality.

- Brian Kamanzi, “Hyperreality in the Colonised World”. (102; original emphasis)

In this chapter, I consider notions of the 'uncanny' - and by extension (more politicised) notions of the 'unhomely' - in Bridget McNulty's Strange Nervous Laughter as well as notions of the 'hyperreal' in Lauren Beukes' Moxyland. The uncanny, on the one hand, is inextricably linked to the doubling and repetition of things such as is related in Sigmund Freud's 'uncanny' incident during his visit to a "provincial town in Italy" in the first epigraph above. According to Freud, our unconscious is subjugated to a 'compulsion to repeat' that he sees as rooted in our instinctual impulses. He argues that this compulsion is "powerful enough to overrule the pleasure principle, lending to certain aspects of 
the mind their daemonic character, and still very clearly expressed in the impulses of small children" and comes to the conclusion that "whatever reminds us of this inner 'compulsion to repeat' is perceived as uncanny" "The Uncanny" 238). Even though Freud establishes a clear difference between doublings and repetitions, both in relation to their (cultural and psychological) origin and the differing types of fear they evoke as we shall see later on, suffice it to say here that it is the emotional and psychological rekindling of long-forgotten fears that lies at the basis of Freud's concept of the 'uncanny' which he sees "as something which ought to have remained hidden [in the unconscious] but has come to light" (241). The 'hyperreal', on the other hand, is marked by "a liquidation of all referentials" as Jean Baudrillard famously argued (2). Baudrillard sees the modern world as essentially emptied of its meaning(s), as he sees reality as being increasingly replaced by its simulations. He opines:

It is no longer a question of imitation, nor duplication, nor even parody. It is a question of substituting the signs of the real for the real, that is to say of an operation of deterring every real process via its operational double, a programmatic, metastable, perfectly descriptive machine that offers all the signs of the real and short-circuits all its vicissitudes. [...] A hyperreal henceforth sheltered from the imaginary, and from any distinction between the real and the imaginary, leaving room only for the orbital recurrence of models for the simulated generation of differences. (2-3)

In this abundance of simulations, it becomes increasingly difficult to "differentiate" and "distinguish" the real from its "imitation" and "fiction" more generally, "[m]aking it impossible to know where one ends. And the other begins", as the opening of Brian Kamanzi's poem "The Hyperreal in the Colonised World", quoted in the second epigraph, suggests (102).

At a first glance, the two concepts seem to have little in common: While the uncanny is of an essentially psychological (and often more personal) nature, the hyperreal is a cultural malaise of the (post)modern world at large where, according to Baudrillard, "the utopia of the principle of equivalence [between the sign and the real]" no longer applies (6). However, the conflation of the 'real' and the 'imaginary' reveals an overlap between the two concepts, as the intrusion of the 'imaginary' into the realm of the 'real' (and vice versa) brings to mind Homi Bhabha's notion of the 'unhomely'. The 'unhomely', which can be seen as a politicised variation of the 'uncanny', refers to the postcolonial subject position which, according to Bhabha, is characterised by its cultural precariousness and displacement (9), a condition in which the post- 
colonial subject's personal history - often traumatised by colonialism - increasingly conflates with its existence within the larger postcolonial context (11). The postcolonial subject's 'unhomely' condition within the postcolonial (and postmodern) world, can thus be seen as one form of 'hyperreality' and the 'hyperreal', in turn, contains aspects of the 'unhomely' and/or 'uncanny'. The interrelatedness between the two concepts becomes evident in the continuation of Kamanzi's poem:

Now.

In the Colonised world.

We live in a time many have decided to call Post-Colonial.

We celebrate, now timeless, tales of struggle for freedom.

Remember Madiba. Nelson Mandela.

The right to vote. The right to participate. The right to shape.

New found emancipation. Brought to us by legend worthy parties that seized power through National Liberation.

The Post-Colonial world.

Is a Hyperreal fantasy. (102; original emphasis)

Kamanzi's poem, which was published in the 2015 special issue of The Johannesburg Salon, is a response to the \#RhodesMustFall student protests of the same year. The protests, among other things, took issue with the increase both in student fees and the overall fees of the universities (Mupotsa). As part of the transformation debate in response to the continuing and increasing difficulty of black (and particularly poor, black) South Africans in accessing institutions of higher education, the protestors demanded the removal of the Cecil John Rhodes statue from UCT's upper campus, which was considered a lasting symbol of white supremacy, and the renaming of Rhodes University. ${ }^{82}$ This inaccessibility of tertiary institutions due to financial constraints denies financially disadvantaged black South Africans an active participation in, and shaping of, that particular space/place, thus rendering post-apartheid/postcolonial South Africa a "Hyperreal fantasy" for them (Kamanzi 102; original emphasis). At the same time, this exclusion bespeaks the 'unhomeliness' experienced by these subjects within South Africa's new dispensation as the public infringes upon the private and the line between the two is blurred.

82 The statue was removed on 9 April 2015 (Hess). 
The crossovers between seeming opposites can also be observed with regard to the genre of the two novels I analyse in this last chapter. Though different in their forms of genre-b(l)ending as I will show, both novels could be labelled as 'ustopian', a term that the Canadian novelist Margaret Atwood coined as a combination of 'utopia' and 'dystopia' (66). Atwood claims: "scratch the surface a little, and [...] you see something more like a yin and yang pattern; within each utopia, a concealed dystopia; within each dystopia, a hidden utopia, if only in the form of the world as it existed before the bad guys took over" (85). As a genre, ustopias are essentially concerned with processes of cartography, both actual and mental and Atwood correspondingly posits that "[f]rom our earliest days, as soon as we can crawl around on the floor, we are inscribing maps of our surroundings onto the neural pathways in our brains and - reciprocally - inscribing our own tracks, markings, and namings and claimings onto the landscape itself" (67). Ustopias, I would argue in line with Atwood, are thereby concerned with a particular form of mapping as they are of a 'speculative' nature in that they "extrapolate imaginatively from current trends and events to a near-future that's half prediction, half satire" (5). Atwood accordingly locates 'speculative fiction' in the works of authors such as Jules Verne who wrote about "things that really could happen but just hadn't happened when the authors wrote the books" as opposed to 'science fiction' which, according to her, is concerned with events far more unlikely (even impossible) any time in the near future and is rooted in the works of authors such as H. G. Wells (6). Despite such a seemingly clear-cut distinction between speculative fiction and science fiction, Atwood highlights the fact that nowadays the boundaries between literary genres in general and speculative fiction and science fiction (and one should mention fantasy for the sake of completeness) in particular have become more fluid as genre-b(l)ending is increasingly popular and common (7). In view of this fluidity, it is not surprising that Paul L. Thomas, in Science Fiction and Speculative Fiction, thinks of, and uses, the two terms in tandem. Personally, I favour the somewhat looser term speculative fiction as it more poignantly accounts for the type of projected spaces and potential, ustopian futures Bridget McNulty's and Lauren Beukes' novels outline.

Bridget McNulty's Strange Nervous Laughter, on the one hand, is set in Durban and follows six seemingly unrelated characters whose lives are inextricably entangled due to a robbery at the local grocery store, an incident three of the novel's protagonists experience first-hand. The novel then follows the three victims and their partners in the aftermath of the robbery as they try to 
process the traumatic event and find their bearings in what turns out to be Durban's hottest summer. Based on Freud's notion of the 'uncanny' and Bhabha's related concept of the 'unhomely', I argue that Strange Nervous Laughter is a ustopian re-negotiation of post-apartheid subjectivities and home-places which speculates about different - more or less successful - life trajectories within South Africa's new dispensation.

Lauren Beukes' Moxyland, on the other hand, follows the lives of four characters in a Cape Town of the near future that is under the control of a number of influential corporate companies and characterised by clear-cut economic delimitations among its citizens as well as their total electronic surveillance. As the novel progresses, the dominance of the corporate world over the lives of the four characters, whose trajectories become increasingly entangled, grows exponentially and the distinction between the 'fictional(ised) reality' and 'fictional(ised) imagination' increasingly fades. Making recourse to Baudrillard's notion of the 'hyperreal', I show how Beukes' ustopian novel is a critique of post-apartheid South Africa's neo-liberal, capitalist system and argue that Moxyland can be read as a 'South African Watergate' where the city of Cape Town features as a 'ghostly' and monstrous automaton that thwarts the characters' personal progress and development, buttressing economic and socio-cultural contrasts instead. 


\subsection{BRIDGET MCNULTY'S STRANGE NERVOUS LAUGHTER}

The author, journalist, and blogger Bridget McNulty (b. 1982), a born and bred Durbanite, holds a degree in Creative Writing and Theatre from Franklin and Marshall College in Lancaster, Pennsylvania. After graduating in 2005, she moved back to her parents' house in Durban for a year and wrote her debut and so far only - novel Strange Nervous Laughter. The novel was subsequently published by Struik in South Africa in 2007 and by Macmillan in North America in 2009. Bridget McNulty now lives in Cape Town with her husband and their two children. She works as the editor of the Magazine Sweet Life (Sweet Life) and regularly writes for National Geographic Traveller, WomanEHome, or the Sunday Times, among others. She is also the co-founder of the online writing course Now Novel (Now Novel), which assists aspiring novelists on their journey from the inception of an idea to the finished product ("Bridget McNulty"; "Bridget McNulty: Profile").

Strange Nervous Laughter traces the lives of six somewhat odd characters who all have a special, not to say supernatural, ability. There is Beth, the selfsacrificing cashier turned motivational speaker who floats whenever she is happy. Meryl, the assistant to a Guinness Book of Records adjudicator, wears a seemingly indestructible corset of cynicism that keeps away any kind of emotion. Mdu, the wunderkind gone wrong/whale whisperer/mind reader, works as a tourist guide on a whale-watching ship. The typist Aisha, who literally lives in her dream world, shuns contact with other people and finds refuge in her rigorous daily routine. Harry, the garbage man with a special odour, is a magnet for broken things and eats green food exclusively. The undertaker Pravesh, finally, has a refined death sensor, takes great joy in deaths of all possible kinds, and in painting corpses' toenails. The novel opens with an armed robbery at a local grocery store. This event brings together Beth, Meryl, and Mdu, three of the six eclectic characters, and the robbery is not the last time the characters' paths will cross. A week later, Durban enters the hottest summer of its history and the novel follows the intricacies of the three victims' amorous liaisons in the aftermath of a traumatic event that has an unanticipated and pervasive influence on their lives.

At first glance, the quirky and generally light-hearted novel simply seems to be a collection of three love stories and their intricacies. Very early on, the reader is told that the novel is "not a tale of crime. Nor about the daily woes of living in South Africa. But rather about love; and what can happen to it when 
combined with the hottest summer Durban has ever known" (B. McNulty, Strange Nervous Laughter 4). Despite - or maybe precisely because of - this attempt at 'depoliticisation', I argue that the novel re-imagines South African post-apartheid subjectivities by re-negotiating different fictional(ised) Durbanite living spaces or home-places, their overlap(s), as well as the ways in which the characters ascribe meaning to these living spaces or home-places. On the theoretical basis of Sigmund Freud's renowned essay "The Uncanny" and with reference to Homi Bhabha's concept of the 'unhomely', I will show that Strange Nervous Laughter depicts the spatio-temporal elusiveness of postapartheid subjectivities and home-places as "complex product[s] of the evershifting geography of social relations present and past" (Massey, Space, Place and Gender 172). This is not only observable in the novel's content and its plot development, but also in the narrative strategies it displays, i.e. its multilinearity, its peculiar narrative situation, and the fact that the novel evades a clear allocation to a particular genre.

\section{Precarious Liaisons}

The armed robbery, which is recounted in the prelude to the novel, sets out both the precarious character and complexity of the (social) relations among the various protagonists. Beth, Meryl, and Mdu, who are brought together as victims of the robbery at Handy Green Grocers by a quirk of fate, form the first triangular constellation, which pre-empts the course of the various ensuing (romantic) relationships. Forming a recurring element, these triangular constellations constitute the basis of the novel's social (micro-)geography (see Figure 11), which leaves the reader with an intricate entanglement of people (in different places and under different circumstances) and reflects the 'uncanny doubling' and the 'repetition of things' (Freud, "The Uncanny" 234-235, 237-238), two important themes throughout the novel, on a structural level.

Apart from the initial happenstance constellation between Beth, Meryl, and Mdu during the armed robbery, each constellation has a romantic relationship at its core, which is destabilised and threatened by a third party. Ultimately, these disturbances lead to shifts within the power-geometries among the characters and leave each triangular constellation with a weak link. This position of weakness excludes the character in question from the respective constellation and at the same time means a confrontation with seemingly longforgotten sufferings; an unleashing of the 'uncanny'. 
According to Freud, the 'uncanny' is "the frightening which leads back to what is known of old and long familiar" ("The Uncanny" 220). Based on the semantic ambiguity of the German word heimlich, which can mean both something "familiar and agreeable" as well as something "concealed and kept out of sight" (224-225), he argues that its opposite unheimlich must refer to the resurfacing of a repressed anxiety from the unconscious, regardless of the fact whether the uncanny stems from an initial effect of fear or not (241). Even though not strictly divisible, Freud distinguishes between the uncanny originating from redressed primitive beliefs (such as the 'omnipotence of thoughts' and the 'return of the dead') and the uncanny deriving from suppressed infantile complexes such as the 'castration complex' and 'womb-phantasies' (248). It is particularly the latter which proves to be a recurring source of problems for the various characters in Strange Nervous Laughter.

Within the happenstance constellation during the Handy Green Grocers robbery, Mdu is established as the weakest link, as he fails to stand his ground and save Beth and Meryl from the two assailants:

In his mind's eye, Mdu can see exactly what to do: disarm both men by grabbing the watermelon to his left and knocking them out, simultaneously signalling the hysterical cashier to call the police. He is young, he is strong; he has in many ways been waiting his whole life for this chance to prove that he is capable of doing something remarkable.

Instead, he remains frozen.

Frozen, as he watches the two men force the wild-eyed cashier to empty all the money from the till, watches as they wave their guns around, shouting, 'Shut the fuck up!' in increasingly loud voices, while she continues to whimper, 'Please don't kill me, please don't kill me, please don't kill me.'

He watches their hands shake as they silently tell themselves, unwittingly in unison, Time to go, hurry the fuck up!

And finally watches as they scan the shop one last time. Then the more confident man, the one in the blue hoody, grabs a Bar One from the check-out counter and tears it open with his teeth.

He grins mockingly at Mdu and takes a bite.

Pussy, he thinks.

The word echoes in Mdu's mind. (B. McNulty, Strange Nervous Laughter 3; original emphasis) 


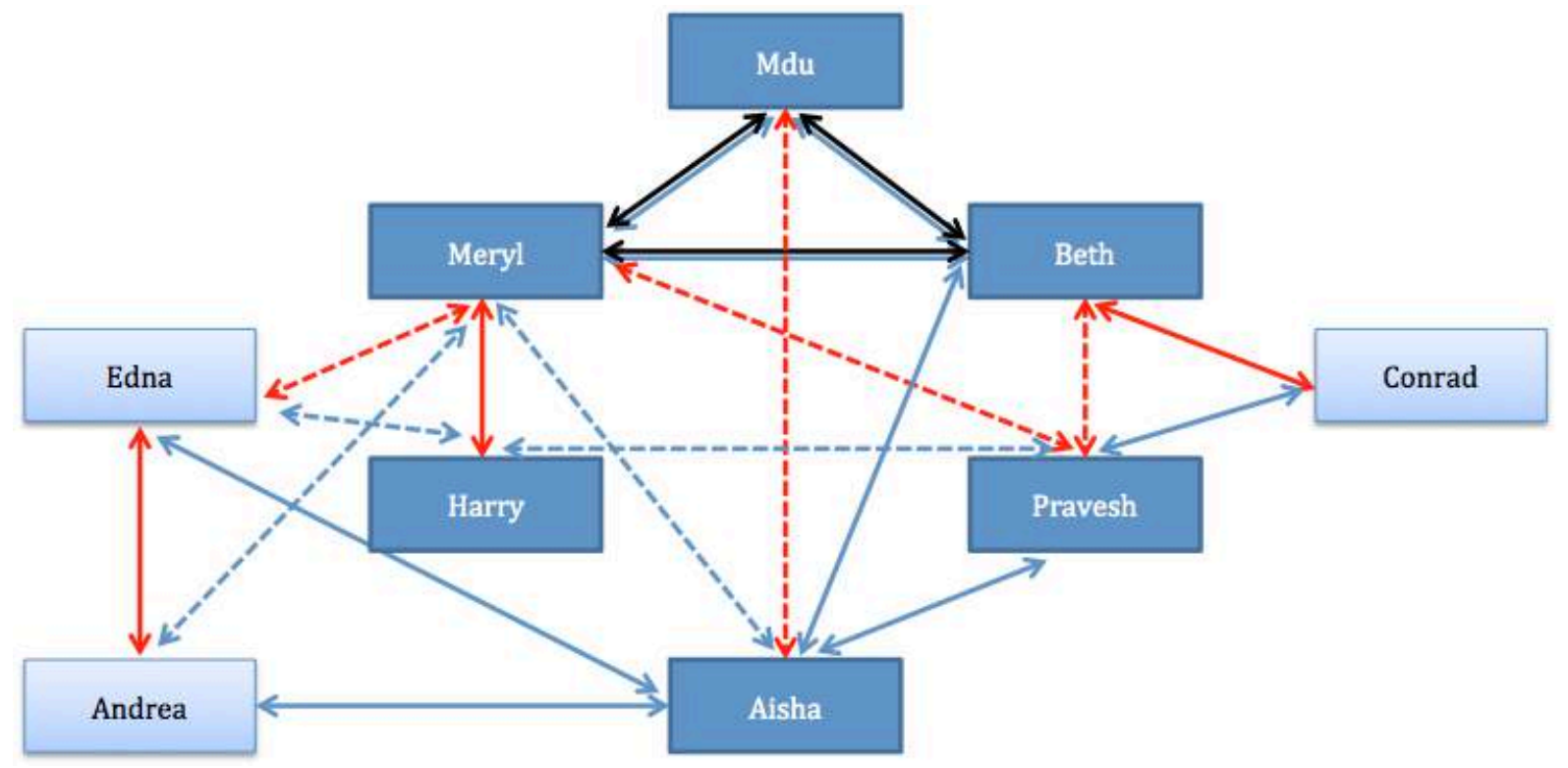

The black arrows connect the three characters affected by the Handy Green Grocers robbery, the blue arrows indicate that the characters are (either directly or indirectly) affected by each other, and the read arrows point to amorous relationships. While the dotted red arrows signify a break-up at some point during the novel, the continuous ones highlight ongoing relationships.

Figure 11: Social Geography in Strange Nervous Laughter.

The robber's insult as well as Meryl's "undisguised look of disgust" (4) as a response to Mdu's lack of action is tantamount to his emasculation. Mdu's cowardice thereby mirrors his failure to fulfil his parents' expectations of excelling in life. As a teenager, Mdu's father forces him under threat of expulsion to cut off his dreadlocks and to start working as a tourist guide on a whalewatching ship. In a symbolic action, "[h]is dreadlocks were carefully preserved in a shoebox on top of his cupboard, and he sometimes took them down to stroke them absentmindedly, but in all other ways he had put aside his younger self" (62). 'Boxed away' in his unconscious, the robbery thus rekindles Mdu's 'castration anxiety' and deeply rooted parent-child conflicts in the most Freudian sense. The ingenious narratological twist in delaying the outcome of Mdu's conflict with his parents, letting the reader experience the same uncanny and traumatic déjà-vu, shall be mentioned only in passing here.

Such infantile complexes are closely linked to ego-disturbances, which manifest themselves in Strange Nervous Laughter either as 'doublings', i.e. the "doubling, dividing and interchanging of the self", or 'repetitions', i.e. the recurrence of similar or identical character traits or flaws, but also recurring de- 
linquencies (Freud, "The Uncanny" 234). ${ }^{83}$ Both forms of disturbance are, according to Freud, "a harking-back to particular phases in the evolution of the self-regarding feeling, a regression to a time when the ego had not yet marked itself off sharply from the external world and from other people" (236), but differ in the type of fear they fan. Doublings, on the one hand, are an uncanny herald of death. With reference to Otto Rank's reflections, Freud explains that in fact there has been a functional change in the 'double' as a sign of immortality - which is typically the case with children and delusional or primitive people - to the 'double' as an emblem of death. This shift is effected when the "narcissism of earliest times" (235), i.e. the ego's developmental stage in which subject and object still overlap, is overcome. Thus, the fear of death that the phenomenon of the 'double' evokes stems from the awareness of the (mental) regression and the instability of the human psyche it reveals. Repetitions, on the other hand, draw their uncanny character from the infantile 'compulsion to repeat'. This urge, Freud suggests, proves to be stronger than the pleasure principle, a power that may lend it a 'demonic' - i.e. a fanatic and/or maniacal - appeal. It furthermore has instinctual character and is probably best compared to infantile impulses, but also finds expression in neurotic behaviour (238).

The phenomenon of the double comes into play with the initial triangular constellation as each of the three encounters finds a 'revival' and each of these reunions entails distress for one of the two characters in question. While Mdu's encounter with Meryl yet again revives his fear of failure, his second encounter with Beth, even if unknowingly, and Beth's encounter with Meryl ultimately lead to the failure of their relationships with Aisha and Pravesh, respectively. While Meryl emerges seemingly unimpressed and strengthened from this initial constellation, her weak spot lies in her relationship with Edna and her difficult relationship with her family, particularly with her father and brother.

The doubling of the initial happenstance constellation is thereby a harbinger of the ego-disturbances that the various characters exhibit. Mdu's parents, for example, almost obsessively foster their highly talented "Golden Child". They "scratched around second-hand bookstores and garage sales to find him every single edition of the Guinness World Records (from his birth year on), painstakingly reading through them before handing them over to Mdu,

\footnotetext{
83 Another type of ego-disturbance Freud discusses in "The Uncanny" is the "omnipotence of thought', such as the fulfilment of negative "presentiments", which he ascribes to the resurfacing of people's former belief in an "animistic conception of the world" (240).
} 
marking certain pages with helpful comments like, Not particularly impressive, and, You could do this!" Initially, their overzealous encouragement seems to achieve its planned effect as Mdu grows fond of reading the Guinness books "and imagined himself on every page" (B. McNulty, Strange Nervous Laughter 17; original emphasis). This overidentification is a sign of the interchanging of Mdu's self with the achievements of others, which in turn become an emblem of immortality, a possibility to inscribe himself in the annals of history. Reaching adolescence, however, Mdu crashes under the enormous pressure to succeed and the many 'free riders' his success brings along. The shaking off of "[a]ll the acclaim, all the praise, all the awards, all the labels that had nothing to do with who he was, and everything to do with who other people thought he should be" (18), thereby becomes a sign of defeat, an annulment of his ego, its symbolic 'death'. The conflict ultimately escalates in the ultimatum issued by Mdu's father. Similar to the way he becomes resigned towards life in general, Mdu gradually sinks into indifference towards the job that is forced upon him, a job he executes "as though sleepwalking" with the result that "his adolescent angst seceded to the much stronger opponent of apathy" (62).

Without anticipating too much, Mdu's behaviour shows eerie similarities to both Aisha's and Meryl's attitude towards their jobs. While the former is described as walking "to and from work in a daze" and doing her job "[1]ike a shadow stubbornly following one step behind" (19-20), the latter is said to be suffering less from "apathy" rather than "crippling self-doubt disguised as bitterness" because of "a job that interested her less than the five-second memory-span of [a] goldfish" (87). Even Mdu's act of storing away his dreadlocks in a shoebox finds its parallel both in Aisha's safeguarding of the little things she steals from her foster siblings (145-146) - and Aisha's petty theft, in turn, is mirrored in Harry's obsession to steal tips (67-68) - as well as Harry's collection of 14 shoeboxes full of comic strips his father cuts out for him from different daily newspapers (154). For each of the three characters the shoebox is linked to a painful memory connected to their childhood and reflects a personal conflict. Another parallel is Pravesh's and Edna's identical justification for their infidelity towards Beth and Meryl, respectively: “'I couldn't help myself, it just happened'" $(113,150)$. There are numerous further examples of such repetitions in character traits, behavioural patterns, or recurring parts of speech. Even if in a somewhat exaggerated - but nevertheless conscious way, these repetitions point out similarities and connections between the seemingly unrelated characters. The minor and major foibles that surface with these repetitions thereby emphasise the characters' humanness and condense 
the entanglement of people that lies at the core of the novel (see Figure $\mathbf{1 1}$ above).

\section{THE UNHOMELY}

In following Freud, the discussion so far has focused on the 'psychological' side of the uncanny. There is, however, also a more 'political' side to it. Homi Bhabha, in The Location of Culture, suggests the 'unhomely' as a way to reflect the postcolonial subject's culturally precarious and displaced condition. ${ }^{84}$ This linguistic variation to the usual English translation of Freud's concept retains the semantic core Heim (home) of the German unheimlich and thus "provides an immediate starting point to relate the sensation of the uncanny to space" (Masschelein 143). According to Bhabha, however:

To be unhomed is not to be homeless, nor can the 'unhomely' be easily accommodated in that familiar division of social life into private and public spheres. [...] The recesses of the domestic space become sites for history's most intricate invasions. In that displacement, the borders between home and world become confused; and, uncannily, the private and the public become part of each other, forcing upon us a vision that is as divided as it is disorienting. (9)

Bhabha's unhomely - the opposite of homely (heimlich in the sense of heimisch, i.e. familiar or homey) - thus implies a threat (by the 'Other') to the homeplace. It is not so much a (physical) loss of the home-place but rather a complex entanglement of the private and the public. It is, however, a threat that links "the traumatic ambivalences of personal, psychic history to the wider disjunctions of political existence" (11).

Despite McNulty's attempt to 'depoliticise' her novel, the robbery involuntarily reflects a (political) threat. An allegory for crime and insecurity, the robbery and South African politics resonate in the way in which Beth's, Mer$\mathrm{yl}^{\prime} \mathrm{s}$, and Mdu's deal with and process the traumatic event. The robbery is, Bhabha would doubtlessly approve, an invasion of the characters' homeplaces by the public sphere, which leaves the three characters with a feeling of disorientation. Time and again the robbery re-emerges from the victims' unconscious in their attempts to resume their daily lives. What is more, this sense of endangerment and insecurity also echoes in the remaining three main char-

\footnotetext{
84 The term unhomely was first suggested by Siegbert Prawer as an alternative translation of Freud's concept of the uncanny. For a concise overview of the term's use and development see Masschelein (136-144).
} 
acters' (childhood) traumas. All six protagonists are thus marked by their past in one way or another and are characterised by a pronounced fragility. As their lives subsequently clash, each of the characters is confronted with other personal histories and further threats to their home-places. The different encounters have different implications for the various characters in their attempts to - more or less successfully - overcome their fears and insecurities, which are highlighted by a continuous re-surfacing of the uncanny and/or the unhomely.

In her review of Strange Nervous Laughter on her personal blog Charlotte's Web, the crime fiction writer Charlotte Otter laments the apparent lack of politics in McNulty's novel:

If it were an Irish novel, or a Canadian one, I'd be yelling yay for the whimsy and the bits of magical realism, which I really rather like [...]. But there is a part of me that still wants my South African literature gritty and that's because life there is gritty. Durban is the epicentre of the AIDS epidemic, most of it is poverty-stricken and crime-ridden. Life there is dangerous, even if you have tall walls and trellidoors to live behind, and far more deadly if you don't.

And here is Bridget McNulty's response to Otter on Thought Leader, the Mail\&Guardian's blog:

It's the eternal argument, isn't it? Do South Africans have a responsibility to write political fiction? Or at least infuse their fiction with a political flavour, a current-affairs edge or some hint of HIV/ Aids?

I think not. ("Politics")

McNulty's wish to distance herself from the country's apartheid history and to renounce political responsibility is understandable. In view of the continuing significance of the country's apartheid past on the post-apartheid present, however, the endeavour seems at the same time a futile one. The ongoing prevalence of apartheid's racial categorisation in South Africa's public (and private) discourses, a fact I have drawn on repeatedly throughout my study, ${ }^{85}$ or the student protests that raged through the country's university campuses in 2015 (and continued throughout 2016), mentioned at the beginning of this chapter, speak to the ongoing relevance of what Hook has called apartheid nachträglichkeit (186-187). In view of the continuing seepage of South Africa's

85 See Posel, "Consume", "Common Sense", and "What's" or Erasmus, "Apartheid Race", and for a more detailed discussion see the Introduction. 
apartheid past into its post-apartheid present, the South African author Damon Galgut rightly claims:

One cannot [...] live in South Africa and write, without, in effect, writing about South Africa. It is a mistake to believe that only overtly political novels reflect this country. Even books that deliberately attempt not to deal with 'relevant' issues are a reflection of politics - after all, a refusal to face up to realities is part and parcel of our daily lives here. All literature is a record of its time. (53) ${ }^{86}$

This is certainly the case for McNulty's novel whose title alone is proof enough of its politically charged nature. Strange Nervous Laughter, involuntarily brings to mind Tsitsi Dangarembga's Nervous Conditions. The novel, which is set in the post-colonial Rhodesia of the 1960s (today's Zimbabwe), tells the story of Tambu who, after her older brother's death, is offered the place at the school her brother used to attend. At the new school she becomes close friends with her cousin Nyasha. Tambu excels in school and is eventually offered a place at a respected missionary school. Even though Tambu remains a zealous student, she remains sceptical, almost resistant, to the cultural changes she is confronted with. The novel's title, stems from Jean-Paul Sartre's preface to Frantz Fanon's The Wretched of the Earth, where Sartre claims that "[ $t$ ]he status of 'native' is a nervous condition introduced and maintained by the settler among colonized people with their consent" (20; original emphasis). The nervousness that both Sartre's comment and the title of Dangarembga's novel make reference to bespeaks the continuing tension(s) between the postcolonial present and the colonial past. In Dangarembga's novel, the postcolonial subject's 'nervous condition' finds expression in Nyasha's eating disorder, which reflects her desire for independence and her difficulties in re-assimilating to her 'old' life in Rhodesia after her stay in England, as well as Tambu's skepticism towards change and her astute awareness of her (as well as other people's) 'nervous', i.e. precarious, 'conditions'. It is the same tension between South Africa's apartheid past and post-apartheid present that characterises the postapartheid subject's '(strange) nervousness', a condition which, in McNulty's novel, is most prominently linked to Harry's character, whose '(strange) nervous laughter' (Strange Nervous Laughter 71, 85, 177) reflects his uncomfortable subject position as a white Afrikaner - the leading force behind the NP's implementation of the apartheid system - within South Africa's new dispensation. Laughter is, however, not restricted to Harry's character and appears in

${ }^{86}$ For a discussion of Galgut's opinion see Kostelac, particularly 54-57. 
many variations throughout the novel, such as bitter laughter, snorting, smirking, or scornful laughter (e.g. 52, 73, 75, 86, 107). In combination, the strangeness and nervousness of the laughter in the novel's title amounts to an 'overdetermination' in the most Freudian sense.

In The Interpretation of Dreams, Freud explains that "[a] symptom is not merely the expression of a realized unconscious wish; a wish from the preconscious which is fulfilled by the same symptom must also be present. So that the symptom will have at least two determinants, one arising from each of the systems involved in the conflict" (569). The concept thus refers to the idea that a person's behaviour, emotions, or dreams result from an interplay of at least two different factors, one stemming from the person's unconscious, the other from the preconscious. Freud gives the following example to illustrate the concept:

In one of my women patients, then, hysterical vomiting turned out to be on the one hand the fulfilment of an unconscious phantasy dating from her puberty of a wish, that is, that she might be continuously pregnant and have innumerable children, with a further wish, added later, that she might have them by as many men as possible. A powerful defensive impulse had sprung up against this unbridled wish. And, since the patient might lose her figure and her good looks as a result of her vomiting, and so might cease to be attractive to anyone, the symptom was acceptable to the punitive train of thought as well; and since it was permitted by both sides it could become a reality. (570)

The strangeness and nervousness in the title of McNulty's novel can thus be seen as representative of this interplay of unconscious and preconscious processes, i.e. of an overdetermination, where the nervousness bespeaks the continuing importance of race in a supposedly non-racial country, and the strangeness the changing/changed power-geometries of South Africa's new dispensation. Within this field of tension between past and present conditions, laughter becomes a crucial coping mechanism for the various characters to confront and (attempt to) overcome their 'nervous conditions' of their strange (i.e. unfamiliar and unprecedented) cohabitation in a formerly colonial, and thus racially segregated, country. This overdetermination of the postapartheid subject, as suggested by the novel's title, can be seen as characteristic of the text's and, by implication, the fictional(ised) world's ustopian character, with the tension and overlap of past and present conditions reflecting the "yin and yang pattern" of the ustopian (Atwood 85). 
In view of Galgut's statement, which I would strongly support, and the above-mentioned examples with regard to the novel's title, Otter's criticism ultimately proves invalid and McNulty's non-political attitude is clearly undermined. It has to be said in fairness, however, that as much as the novel's title as well as the robbery are of a politically charged nature, McNulty's nonracialist tenor has a 'depoliticising' counter-effect. It is striking to what extent race takes a backseat throughout the novel or is indeed marginalised compared to the usual importance of race (and politics) in South African literary texts. While the robbery - one could say stereotypically - victimises a white woman (Beth), the robbers are described as "two men with hooded sweatshirts and hand guns" (B. McNulty, Strange Nervous Laughter 1). This description renders both the robbers as well as the ensuing threat as (racially) unidentifiable. Overall, the novel gets by with only a handful of racial markers. Except for Pravesh and Harry, who are identified as Indian (11) and Afrikaans (26) respectively, the novel avoids explicit racial labelling. The remaining characters' race can be deduced from their given names as well as more indirect racial markers and the context. While Mdu is described as "a tall, dark, scowling man" (1), Aisha is said to have "chocolate skin" (54). Meryl's face is "usually chocolate-chipped with [freckles]", but they disappear when she's upset "making her look pale and wan" (24). And Beth, finally, has "pale skin", which the sunset bestows with "a rosy hue" (199). The novel's general racial non-markedness, I would argue, again stresses the characters' humanness as a common good. In foregrounding the characters' personal stories rather than those of a whole community, the novel unites a group of seemingly disparate characters under a unifying cover in order to highlight communality rather than separateness.

\section{The City of Durban in StRANGE Nervous LAUGHTER}

The atmospheric tension that the novel's title suggests also forms a primary constituent of Durban's depiction from the very beginning. In its first account, Durban is described as "the city at the heart of KwaZulu-Natal, the province at the heart of Aids in South Africa" (14). This sets the novel loosely in the Mbeki-era of AIDS denialism and Durban's description continues accordingly: 
Death that summer was so relentless it had outweighed the birth rate in Durban; the very air was infected with it. The colour, the heat, the intoxicating closeness of the city must inevitably have intensified the scent of fatality on the hot breeze. (14)

With no more than life and death as its coordinates, Durban is thus characterised as an 'edgy city' or a 'city of extremes', as Kruger and Martin Murray (City of Extremes) argue for Johannesburg. This edginess is reflected in the city's extreme meteorological conditions - remember that the novel takes place during the hottest summer in Durban's history (B. McNulty, Strange Nervous Laughter 4) - which bestow the novel with an apocalyptic tenor (discussed further below).

This basic extremity finds further expression in the description of the city's social architecture:

There was no second world in Durban, Pravesh mused while driving. The third world rubbed shoulders with the first, and wondered where it had gone wrong. The lines had always been clearly demarcated; the crushing throngs of people in the city giving way to the sterile peace of the suburbs. But over the years the city and the suburbs had been involved in a dogged tug-of-war. Streets that used to be good neighbourhoods to raise children in were now good neighbourhoods to buy drugs in, and areas that used to be high danger zones were being developed into high-income zones.

It was like a real-life game of Monopoly.

The city centre - with all its late-night shebeens, homeless people sleeping in cardboard boxes, rank alleyways, overflowing dustbins, hookers in skimpy eighties outfits, fried chicken take-outs, tiny flats and council houses with Nigerians sleeping ten to a room - crept closer to the suburbs each day.

The suburbs - with all their book clubs, afternoon teas, art exhibition openings, dinner parties and strolls around leafy blocks - lived in denial. Being there felt like visiting a different country. (39)

Underneath the primary dichotomies, this account suggests an ongoing (violent) exchange between the "third" and the "first world", between the city centre and the suburbs, between the centre and the periphery, and it is as part of this flux, I would suggest, that the relationships between the novel's different characters have to be seen. As much as the various relationships are encounters of the 'Other' and as much as the city's depiction in its antagonistic extremes and edges may seem to corroborate basic dichotomies, the various relationships have to be seen as fictional(ised) attempts to undermine and go be- 
yond simplistic oppositions, particularly since every bilateral relationship is extended into a (precarious) love triangle. Pravesh's description of the city's two worlds of extremes as "cre[eping] closer [...] each day" thus characterises Durban as an unhomely place and this class conflict, such as it is also depicted in K. Sello Duiker's Thirteen Cents and Lauren Beukes' Moxyland, is another characteristic of the ustopian. Overall, it can thus be said that the relationships explore alternative ways of living in the ustopian post-apartheid city, some successful and others not, the novel highlighting the spatio-temporality of social relations in the ever-shifting triangular constellations between the various characters. Durban becomes a city, like any other "Afropolis" (Mbembe and Nuttall 1), in which day-to-day life continues and people make do even - or especially - under extreme conditions (Simone, Always 16-23).

Thus, on a more positive note, the description of Durban's beachfront, for example, as:

usually abuzz with cool-kid skateboarders in baggy pants, sneaky-kid pickpockets with bare feet, street children holding polystyrene cups out for 'donashuns, please', volleyball players showing off their moves, old men in long socks going for a stroll, Shembe priests laden with chicken sacrifices and candles, Zulu women in clinging T-shirts taking photos of each other, sand sculptors sitting proudly behind their rugby-playing sharks, policemen cruising in their shiny cars, bikini-clad girls cruising the beach, tourists wearing socks and slops and expensive cameras, beggars wearing hopeful looks, surfers jogging into the sea, and fat men jogging into shape [...]. (B. McNulty, Strange Nervous Laughter 53)

As such, this passage attests to Durban's multiculturalism and integrative character, which reminds of similar descriptions of Durban's beachfront in Johan van Wyk's Man Bitch and Lewis Nkosi's Mating Birds, I discussed in Chapter 2.1, and undermines the previous depiction of the city centre as a hub of potentially subversive activity. Its decidedly more favourable tone dismantles a simplistic 'zebra thinking' in favour of a more flexible spatio-temporal order.

On an even more positive note, here the novel's emphasis of Durban's rich Indian heritage:

Harry loved the market, loved that he could arrive and instantly blend in, despite his pale skin, because there were so many people crammed into such a small space. The air smelt like curry twenty-four hours a day, and especially on Saturday mornings, when the apartment windows in the blocks surrounding the market exhaled their scent of pots on the simmer. Harry could also pick up 
the sweet smell of incense from the mosque at the top of the hill, and he loved the call to prayer that echoed through the neighbourhood as the sun began to set.

It reminded him of his childhood, when they had lived three streets away from a mosque. (165)

The passage instantly brings attention to the sensory experience triggered by Harry's visit to the Indian market, which combines visual and acoustic elements together with a rich blend of scents, similar to the reflectively nostalgic descriptions of the Grey Street area in Mariam Akabor's Flat 9 and District Six in Rozena Maart's Rosa's District Six (see Chapter 1). And yet, in its broader context it is at the same time a subliminal allusion to the 'racialisation' of space, as Harry:

liked to imagine that he'd just popped over to India on these trips to the market. A shimmer of heat made everything more exotic, piles of fruit and vegetables spilled out of shops scented with spices, and every doorway seemed to hold a wrinkled old Indian man with gaps in his teeth wearing a faded cotton shirt. (165)

It is striking to what extent Harry exoticises the market, which makes Harry's experience stand in stark contrast to Fatima's stroll through the market in Akabor's short story collection. Harry's perception is restricted by his naivety and an underlying structural racism. In Harry's subconscious racist presumptions everything that is familiar to him is involuntarily linked to his Afrikaner, and thus white, background. On the basis of his 'familiarity' with the area and due to the fact that he grew up near a mosque, Harry's venture through the market amounts to a (mental) 're-appropriation' that is reiterated with each visit to the market. Overall, this incongruity between a positive over- and a negative undertone feeds into the antagonistic clash between Durban's "first" and "third world" as depicted in the second quote above (39). In this regard, Harry's behaviour is, at least initially, comparable to Johan van Wyk's inability to adapt to the changing/changed post-apartheid conditions in Man Bitch. In contrast to van Wyk, however, Harry ultimately does not fail but is able to accommodate the necessary changes, even if under extreme conditions as will become evident later on, to personally evolve and move forward. Harry's character and story thus become a beacon of hope for the post-apartheid subject's ability to conquer the ambiguity of the ustopian post-apartheid city in favour of a more harmonious post-apartheid future. 


\section{MAPPING LOVE AND TRACING HOME-PlaceS}

Having discussed the various ways in which the uncanny/unhomely manifests itself in the novel as well as the novel's depiction of Durban, I will now turn to the three central amorous relationships that evolve throughout the novel: (1) Beth and Pravesh, (2) Mdu and Aisha, and (3) Meryl and Harry. Overall, one could describe the three relationships as encounters with the 'Other' or encounters of extremes. While the relationship between Beth and Pravesh is maybe best described as an encounter of clashing personalities, the one between Mdu and Aisha is an encounter between reality and the imaginary as well as an encounter between the world of letters and the world of images - Mdu turns out to have a gift for writing and Aisha rediscovers her passion for painting $(137,147)$. The last relationship contrasts the experienced and (emotionally) detached Meryl to the innocent and naive Harry. For each of the relationships the novel maps a distinctively different trajectory. In what follows, I will trace these trajectories and their connection to the characters' home-places.

\section{Beth and Pravesh}

Beth's and Pravesh's relationship corresponds to a contrasting up and down movement and is characterised by a strange power play from the very beginning. Throughout their early dating process, Pravesh is completely silenced and overpowered by Beth's overenthusiastic and chatty character. Figure 12 displays Beth's and Pravesh's 'dating itinerary' that highlights the initial thrive and mobility of their relationship. From a topological point of view, it exposes the polarity of their personalities. While Beth's choices involve loud, busy places and fun activities (Rowdy Ranchers, Funworld, karaoke singing at Cockle Jack's, and bowling), Pravesh's suggestions include more quiet and withdrawn places (the Blue Waters Bar, the Antique Café, La Lampara). From a topographical point of view, it displays an overall inland movement. The first two follow-up dates that take place at the beach, the liminal and fluid inbetween space/place (of potentiality) between land and sea, are thereby in stark contrast with their Sunday lunch date at La Lampara (44), an Italian restaurant in the KwaZulu-Natal Midlands (a good two hours' drive from Durban). The trip to the countryside is thereby both climax and 'aberration', as it not only denotes the peak of the couple's mobility but can also be looked at as a herald for the extremity of both Pravesh's imminent change in character as well as his subsequent profound (mental) regression. 
The initial thrive is followed by an uncontrolled emotional unloading on Pravesh's part which inverts the power-geometry of the relationship and expresses itself by:

the lack of romance, the cessation of all excitement, the total absence of fun ... and the fact that Beth had somehow turned into Pravesh's maid. In too much of a funk to wash his dishes, make his bed or sweep his floor, she did all of Pravesh's chores. He couldn't even manage to take out his rubbish. (91)

It is striking how their relationship, in stark contrast to the mobility of their early courtship, becomes spatially bound to Pravesh's flat and how Beth is 'incorporated' into Pravesh's home-place. The heaps of rubbish thereby not only speak to the one-sidedness of the relationship but also to Pravesh's repressive power over Beth despite the inherent immobility.

However, this is only a precursor of Pravesh's (short-term) high. Once Pravesh tells Beth about his little toe painting obsession (98), he enters a phase of excessive partying. Equipped with his newfound self-confidence, Pravesh starts an affair with Meryl and unceremoniously dumps Beth. Once Pravesh declares his love to Meryl, though, the latter ends their fling in turn and when he loses his job being caught painting corpses' toenails in his underwear, Pravesh's misery unravels. While Beth becomes a successful motivational speaker and travels all around South Africa, Pravesh enters a gradual retreat and (mental) regression.

Encapsulating himself in his apartment henceforth, Pravesh becomes an avid fan of the pop star Candy K. In his delusional overidentification with the pop star, he is eventually forced to give up his apartment for financial reasons and moves back 'home' to his parents. Confronted with his "childhood prison" (197) and his parents' exuberant love, Pravesh's crisis worsens and he hits rock bottom when meeting Beth and her new boyfriend Conrad after one of Beth's speeches. Humiliated in front of Beth and Conrad as he is wearing "nothing but Candy K treasures: socks, boxers, T-shirt and cap" (199) and subsequently mocked by a group of teenagers, Pravesh suffers a complete breakdown. He burns all his Candy K. fan items and withdraws himself - first under his bed (204) and, when his mother locks him out of his room, under the sofa (205). Ironically, Pravesh's and Beth's story ends with him listening to one of Beth's motivational speeches and " $[w]$ ith a loud groan Pravesh closed his eyes. His death radar started tingling" (206). 


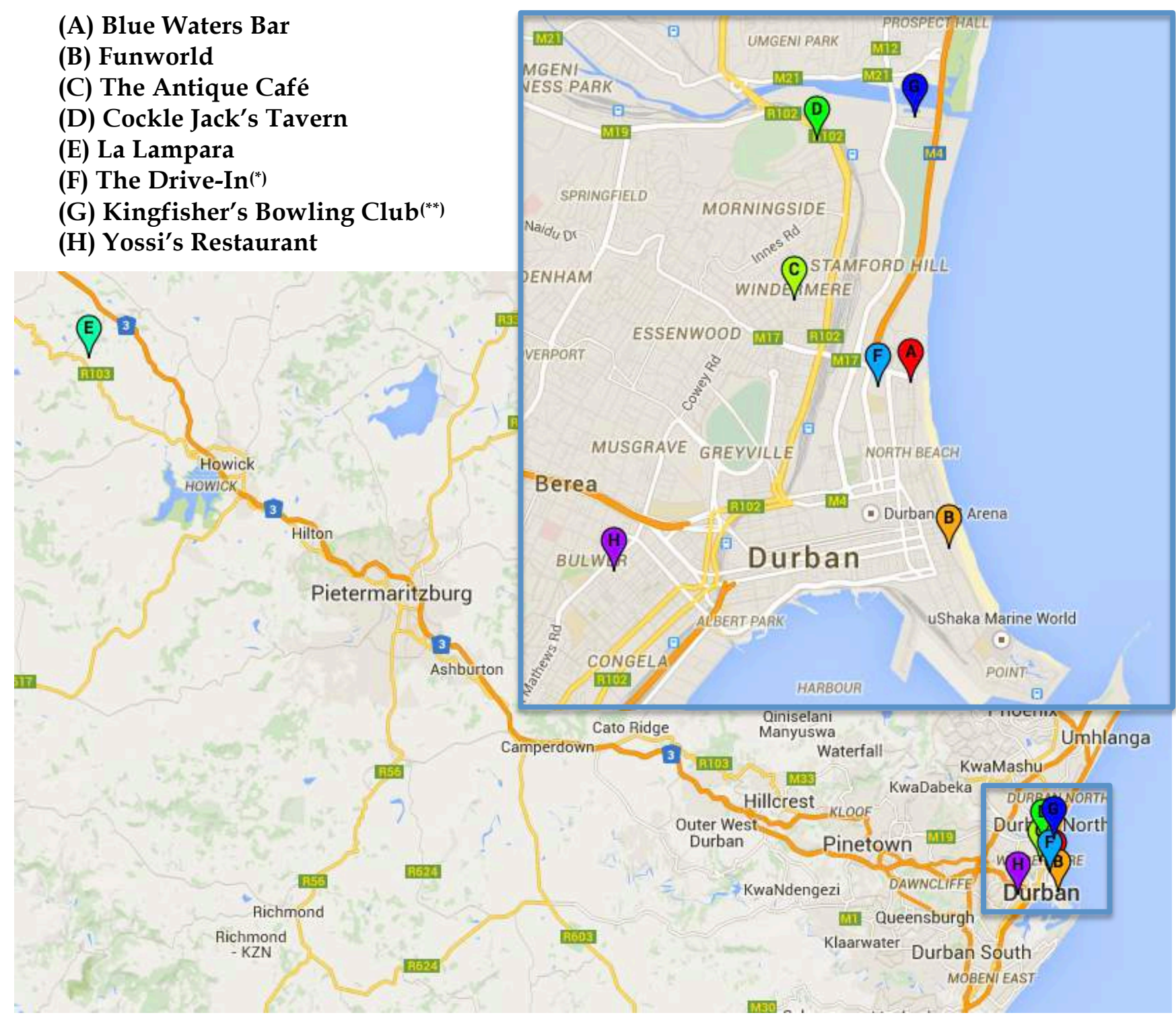

$\left.{ }^{*}\right)$ The Drive-In used to be on that stretch of land near George Campbell School of Technology (B. McNulty, "Re: Quick Question").

${ }^{(*)}$ The Kingfisher's Bowling Club is based on the Collegians Bowling Club (B. McNulty, "Re: Quick Question").

Figure 12: Beth and Pravesh's Dating Itinerary Displayed on Map of KwaZulu-Natal.

Beth's and Pravesh's counter-posed emotional roller coaster leaves the reader with an ambiguous picture. In line with their contrary personalities, their stories take opposing endings. Beth, on the one hand, is able to overcome her initial position of weakness within the love triangle between herself, Pravesh, and Meryl and overcomes her repressed traumas, i.e. the robbery and her self-sacrificing tendencies. Pravesh, on the other hand, loses the position of power he gains at the expense of Beth and eventually becomes the weakest link in the new relational triangle between himself, Beth, and Conrad. His (partial) 'return to the womb' (even if not entirely of his own volition) - im- 
plied in his moving back in with his parents, who live in a gated community (note the intended pun), and his hiding under the bed and the sofa - suggests a longing for a protected and secure home-place. Pravesh's 'return to the womb' here is reminiscent of Azure's time atop Table Mountain where the cave in which he finds shelter from the storm on his second ascent to the mountain functions as a 'creative womb' of sorts which supports Azure's selfdiscovery and the re-actualisation of his black subjectivity (see Chapter 2.2). Ultimately, it is not entirely clear whose death Pravesh senses. Considering the fact, however, that in the month leading up to the morning on which he listens to Beth's self-help CD he is said to be "in the hopes that his death sensor would soon start its last furious tingling as his own body slowly shut[s] down" (205), it seems that Pravesh's story comes to a bad end, that he becomes the 'falling man' he admires on the façade of the house next to Beth's after their first date (40). The 'falling man' in McNulty's novel can be seen as an uncanny reminder both of the precariousness and instability of the postapartheid subject position as it pre-empts Pravesh's probable death. At the same time, McNulty's novel is, as I argue, precisely concerned with mapping out differing courses of action in seemingly hopeless situations.

\section{Mdu and Aisha}

Mdu's and Aisha's relationship is best described as a circular movement which finds its beginning in Aisha's rescue from the sea and ends with her flight back to the freedom and comfort thereof. This circularity is thereby reinforced in the recurring sea- and whale-motif that runs through their love story like a golden thread.

Meg Samuelson convincingly argues that the sea, "a site of both separation and connection", suggests "a fluidity of meaning" which is open to "flows of otherness" ("Oceanic Histories" 545, 557). In Mdu's case, this openness to the 'Other' is for example reflected in his initial encounters with the whales at an abandoned "rocky outcrop" (B. McNulty, Strange Nervous Laughter 59). It is in this in-between space where the land reaches out into the sea - the door to a ustopian 'other world' (Atwood) or even 'counter world' - that Mdu's potential is at its strongest and its most vulnerable at the same time. While "[i]n the whales Mdu found what he had struggled to find in people - extraordinary intellect, and the unreserved acceptance that he was not normal" (B. McNulty, Strange Nervous Laughter 58), the presumed security of the place is constantly endangered by the threat of Mdu's parents finding out about his secret. Ultimately caught by his mother and pushed to become a whale guide by his fa- 
ther, Mdu is forced to (financially) exploit his gift and is subsequently stuck in the capitalist flow between land and see.

At first glance, Aisha is caught in a similarly inert situation, as she leads an uncanny doll-like existence within a self-inflicted make-believe world. ${ }^{87}$ Her longing for security and comfort, two things she sorely lacks growing up in the foster system (144-146), are provided by a strict routine: "walk to work, past Handy Green Grocers to buy lunch. Work. Walk home from work, past Handy Green Grocers to by dinner. Home" (21). Aisha's automaton-like existence thereby speaks to her child-like mental state, or indeed her mental instability, that is reminiscent of early children's games in which children "do not distinguish at all sharply between living and inanimate objects" (Freud, "The Uncanny" 233), an indication that the separation between subject- and objectworld is not yet fully developed. In the light of Aisha's ego-disturbance, it is foreseeable that the first deviation from her routine starts the ball rolling. Agreeing to a girls' night out with her work colleagues, a veritable physical torture begins for Aisha as a direct result of her dis-location from of her comfort zone. As the evening progresses, her physical pain, which seems to be increasing in proportion to the duration of time, spreads until "[e]very muscle in her body felt tense" (B. McNulty, Strange Nervous Laughter 51). After a sleepand dreamless night, Aisha resorts to a walk along the beach as a final rescue, but in vain. Under tears and rainfall, she swims out into the ocean, "away from life" (54) and into Mdu's arms. For Aisha, the sea is thus a place of rescue from her forced dis-location. It is, however, also the place of encounter between Aisha and Mdu, an encounter that renegotiates the boundaries between reality and imagination. The constant renegotiation of the 'real' and the 'imaginary' in, and by means of, Aisha's and Mdu's story, allows a reading of their relationship along Baudrillard's notion of the 'hyperreal'. Baudrillard's concept, as I have briefly shown in the Introduction to this chapter and will discuss in more detail in the second half, is concerned with the (post)modern world's fundamental emptying of meaning as a result of the replacement of reality with its continuous simulation. If transferred to Aisha's and Mdu's situation and, by implication, the South African context at large, Aisha's and

\footnotetext{
${ }^{87}$ Aisha's character is, to a certain extent, reminiscent of the protagonist, Laura, in Tennessee Williams' The Glass Menagerie. There are several salient parallels between the characters of Laura and Aisha. They are both introverted and unsociable and forced to socially engage, Laura by her mother and brother, Aisha by her work colleagues and Mdu. More importantly, however, Laura's glass menagerie - symbol for her delicacy and fragility, but also her uniqueness - finds an equivalent in Aisha's tears, which ultimately bespeak Aisha's vulnerability and by extension the fragility of black post-apartheid subjectivities.
} 
Mdu's relationship can be seen as an allegory to the precariousness of the black post-apartheid subject that still struggles to find its bearings within South Africa's new dispensation.

This symbolic aspect is corroborated by the whale-motif. Ralph Goodman successfully argues with regard to Zakes Mda's The Whale Caller, which in any case seems to provide many foundations for McNulty's novel, 88 that:

As a being who is neither entirely black nor entirely white, not always present [...], but intensely present for some time, neither completely involved in the action nor entirely uninvolved in it, neither strictly speaking a fish, yet having the outward appearance of a fish, Sharisha [and, by implication, the whale more generally] is well equipped to occupy a liminal position in this text, opening up spaces of discursive contestation. ${ }^{89}$ (110; my emphasis)

However, the whales' migration patterns also suggest a "shift [in] critical attention from 'roots' to 'routes'", to borrow Meg Samuelson's splendid argument which references Paul Gilroy's The Black Atlantic in relation to the significance of ships in Zoë Wicomb's oeuvre (“Oceanic Histories" 549). 90

Both aspects of (up)rooting and travel as well as the constant renegotiation of (their shared) reality are central to Mdu's and Aisha's relationship. From the moment of Aisha's rescue, where Mdu gets to accomplish the

88 Zakes Mda's The Whale Caller tells the story of an unusual love-triangle between a man, a woman, and a whale. The Whale Caller's life revolves around the seasonal arrival of the whales in the small coastal town of Hermanus (Western Cape Province). He spends the whole whale(-watching) season playing the kelp horn for Sharisha, a southern right whale he is particularly fond of. When Saluni, the town drunk, enters the Whale Caller's life, however, the problems start, as he is torn between his long-lasting love for Sharisha and his new feelings for Saluni.

The parallels between Mda's and McNulty's novels are numerous. The basic love-triangle of Mda's novel, for example, offers a structural parallel to the various triangular constellations in Strange Nervous Laughter. The rising issues of jealousy and rivalry between the protagonists or the longing and love for nature in The Whale Caller are thematic parallels, particularly with regard to Mdu's and Aisha's story. Note also The Whale Caller's disgust towards the masses of tourists that finds its parallel in Mdu's indifference towards his job or the tragic endings to both of Mda's novel as well as Mdu's and Aisha's story.

89 The whales in Strange Nervous Laughter are killer whales or orcas. Sharisha in Mda's The Whale Caller is a southern right whale. Both species are black and white. Orcas, on the one hand, have a white eye patch and belly, while their head and back are black. Southern right whales, on the other hand, are generally black and typically have white callosities on their heads.

90 Zoë Wicomb's Playing in the Light features similar elements of animal symbolism. The novel opens with a black and white guinea fowl's death from a heart attack on Marion's balcony, which she quickly wraps in a shawl and leaves for her maid to dispose of. The event artistically forebodes the imminent changes in Marion's life, the very foundations of which are about to be shaken by her discovery that Tokkie, her supposed coloured domestic worker, was in fact her maternal grandmother and that her parents were so-called 'play-whites'. 
heroic deed he so miserably fails to achieve during the robbery and which frees him from the repetitive movement between land and sea, their lives seem to be both in synchrony but at the same time characterised by a delicate balancing act between reality and illusion. With Aisha's "tender kidnapping" (B. McNulty, Strange Nervous Laughter 128) to Mdu's home-place, the synchronisation of their lives is also spatially marked. Even though Mdu seems to be acting with the best of intentions, Aisha's 'forceful' incorporation into Mdu's home-place amounts to her renewed dis-location, which is highlighted by the fact that her home-place is subsequently 'deleted' and never mentioned again throughout the remainder of the novel.

Mdu's alleged position of power, however, is undermined by the allure of Aisha's dream world:

[Aisha's] tears, which had flowed so ceaselessly the first night, continued to fall, spilling small iridescent beads all over his bed and floor. After three days, Mdu had collected two large bowls and two tall vases of tears, and their scent was so strong that he often felt, on waking, that he was somewhere distant out at sea, perhaps - far away from any human contact.

It felt as if the air they breathed in that little house was one part oxygen, three parts dreams. Just enough to keep them conscious.

Mdu soon found himself talking in his sleep, to the whales, and even that did not seem so strange.

A warning sign he chose to ignore. (132)

Aisha's tears can be seen as an invasion of the sea into the land, an intrusion of the dream world into reality, and an imminent threat to Mdu's newly found freedom. His failure in containing Aisha's tears is ultimately a harbinger of their love story's end that is echoed in the constant reoccurrence of the whaleand sea-motif. Out of fear of losing Aisha and in order to keep the threads in his hands, Mdu strips Aisha of her dream world and selfishly suggests travelling around South Africa, thus yet again dis-locating Aisha. What he is not aware of is the pseudo-reality of their co-created (travelling) world. ${ }^{91}$ Their 'love bubble' is constantly threatened both by the unspoken hopes and expectations that the two place on each other (146) as well as by the spatial restrictions they impose on their travelling route. They not only agree to sidestep urban commercial and entertainment areas, such as shopping malls and casi-

\footnotetext{
91 This reminds of Marion in Playing in the Light who, despite the fact that she hates travelling, is the owner of a successful travel agency. Ironically, she is - similar to Aisha - forced to travel inland in her search for information about her coloured maid Tokkie.
} 
nos (209), but due to Aisha's somniloquy, during which she "spoke of the ocean with such intense longing that it brought tears to her eyes" (215), the two also avoid coastal areas. The imaginary or pseudo-real character of Mdu's and Aisha's (travelling) world is furthermore doubled in the media attention their weekly (literary and picturesque) column gets. The illusion of their 'perfect romance' ironically even sparks a spurt of 'literary tourism' as Harry recreates Mdu's and Aisha's route for his honeymoon (238).

Soon, Mdu's carefully assembled house of cards starts imploding. Upon their arrival in Johannesburg their equilibrium "with nature's rhythm" (216) is thrown out of balance. This plot twist is a weaving in of the archetypal 'Jim Comes to Joburg'-genre, which typically addresses the city's ambivalent status as both a place of opportunity as well as delusions and threats (Heywood 2526, 104). Hein Willemse argues that most novels of the genre, such as Peter Abrahams' Mine Boy or Alan Paton's Cry, the Beloved Country, "bear an antimodernisation message of urban decay, personal neglect and debauchery, often ending with the redeeming insight that the city is a bad place" (437). When the couple meets Beth, the initial dysrhythmia quickly turns into a proper (relational) standstill. Captured by her aura, Mdu, for the first time, shifts his focus of attention away from Aisha. Aisha's initial fit of jealousy evolves into a state of shock when Mdu reveals his interest in becoming a motivational speaker. Her silence during the trio's encounter not only emphasises her position of weakness within the triangular constellation, but also pre-empts her subsequent loss of voice and with it her loss of confidence in Mdu. Again, the state of the crisis is spatially reflected:

Their bedroom, on the seventeenth floor, felt like a large cardboard box decorated by a young child - two beds, a miniscule bathroom that reeked of cigarette smoke, a big TV hanging over the bed, and a window that refused to open.

An enlarged photograph of the ocean - framed in cheap, pink plastic and showing nothing but wave after endless wave - took pride of place in the centre of the room.

Mdu parted the curtains and stared out at the city skyline, a lightning storm flashing on the horizon, lighting up the clouds like little bombs.

He watched it, mesmerised.

'Aisha, look at this,' he said, turning to her.

But she was already asleep [...]. (B. McNulty, Strange Nervous Laughter 219)

While the room's cardboard texture suggests the relationship's fragility, its 'boxing' character implies the relationship's deadlocked position. The jammed 
window and the stale cigarette smell from the bathroom further corroborate the stalemate, as if the relationship's oxygen supply had been cut off and its smoke poisoning was imminent. The oversized bedroom as opposed to the bathroom's limited size, in turn, reflects the contrast between their liberties in the countryside and the restrictions the city imposes on them, a detriment that is set before the reader's eyes once more in a mise-en-abyme with the photograph of the sea that hangs on one of the walls. The city's negative effect on Aisha's and Mdu's relationship in Strange Nervous Laughter - similar to the city's negative portrayal in Man Bitch, Thirteen Cents, or, as I will show in the second half of this chapter, Moxyland - thus buttresses the post-apartheid city's 'monstrous' character which, in turn, is reminiscent of the city's negative depiction in the popular 'Jim comes to Joburg'-genre. Together with the impending storm, the picture anticipates the looming tragedy of Aisha's return to the sea, Mdu's pursuit, and the disappearance of the two. With their (probable) death, the circle is completed in a tragedy of almost Shakespearean proportions, only under inverse auspices if compared to Shakespeare's famous "star-crossed lovers" (I.Prologue.6). A somewhat less tragic reading of the ending of Aisha's and Mdu's story might simply argue for their removal from post-apartheid society where they seem not to have found 'their place'.

\section{Meryl and Harry}

With Meryl clearly dictating the terms, Harry's and Meryl's relationship is marked by a significant imbalance of power. Nevertheless, it is best described as a parallel or countervailing movement overall as it is the only central relationship that survives its ups and downs.

Meryl, on the one hand, suffers from multiple divisions of her 'self' (Freud, "The Uncanny" 235). Each time she comes under (emotional) pressure, Meryl adds another self-division: In reaction to being left alone by her father and brother to accompany her mother until her death, she develops her "corset of cynicism", "a bizarre condition, a self-chosen disability", which "tightened her in every way; kept her hair shinier, her skin smoother, her expression more inscrutable" (B. McNulty, Strange Nervous Laughter 22-23). In addition to her self-imposed lack of emotion, she subsequently renounces the world of men and initiates a lesbian relationship with Edna. However, when Edna cheats on her with Andrea, Meryl contractually binds Edna to herself (152) and takes revenge on Edna by having an affair with Harry. Considering the fact that Edna is a self-declared man hater, Meryl's affair with Harry ensures her maximal destructive force. When Harry, finally, proposes to her, she cre- 
ates her alter ego Tracy (183) and starts an affair with Pravesh (184). These self-divisions are spatially reinforced, as Meryl keeps her love interests spatially separated and the various characters involved with her never personally meet. ${ }^{92}$ Ultimately, Meryl's self-divisions are her way of securing her position of strength. Ironically, it is Harry, the most atypical and anti-heroic character, who manages to undermine Meryl's seeming indestructibility and loosen her emotional numbness.

Harry, on the other hand, lives a marginal life, which is not only defined by his employment as a garbage man but also by the location of his homeplace. He lives in a "ramshackle house right next to the dump" (64), "whose borders crept closer and closer each day" (70). Burdened by a strange body odour that is "a pheromone for damage" (64), he makes a virtue out of necessity, passionately sifting through mounds of rubbish, collecting broken things from the dump and exhibiting them in his overflowing house. It is striking, however, how Harry's naive and somewhat helpless optimism helps and allows him to transform his seemingly uninhabitable place into a habitable one. One could argue that the act of transforming inhabitability into habitability lies at the basis of Harry's 'sense of life', as he "loved his work, loved making other people's lives cleaner, loved feeling like a magician who miraculously removed all evidence of every-day existence" (63). Ultimately, it is Harry's willingness to embrace the entanglement of the public and the private and his involuntary opposition to unhomeliness that distinguish him from the other characters and can be seen as a symbolic 'undoing' of the/an Afrikaner's burdened subject position.

In view of his naivety, it is nevertheless a noteworthy plot twist that Harry stands up to Meryl, who seems to know every trick in the book when it comes to manipulating other people into doing what is in her best interest. Agreeing to make a sacrifice but - and that is, I would argue, the crucial difference in comparison to the other couples discussed above - not unconditionally, Harry proves himself a 'saviour figure'. Upon returning from his miserably failed tip-stealing-spree after learning about Meryl's affair with Pravesh:

92 There are indirect spatial overlaps, though. In her attempt to sabotage Meryl's and Harry's affair, Edna tracks down Meryl and Harry and witnesses their first date. While Edna sets eyes on Harry, the latter never learns of her presence (160-164). Similarly, Pravesh follows Meryl to Harry's (home-)place after their affair ends in order to deliver an envelope containing a braid of his pubes and a card. Yet, there is no visual or physical contact between the two men (239-240). 
[Harry] wasn't quite ready to go home, so he parked his car in a secluded spot and slowly began the long climb up the slope. The clouds were now so low that Harry felt like he was climbing into them, and the hot wind stirred up the loose debris, sending objects whipping through the air.

Lightning lit up his path, exposing potential hazards, like rusty spokes and soft, oozing patches, but Harry was used to it. This was his hood. The wind grew stronger the higher he climbed, and by the time he reached the top of the slope, he had to lean into it to prevent being blown away. Lightning flashes flared around him as Harry sank into a broken-down armchair he had placed on top of the dump, his home away from home.

He sighed.

$[\ldots]$

But he was not used to someone who loved him doing something so obviously hurtful. Even though Harry had no real friends to speak of, no living family, no ex-girlfriends and no company save the stray cats, he knew how he wanted to be treated. (244)

In an allusion to the biblical narrative of the revelation at Mount Sinai (Authorized King James Bible, Exodus 19-40), Harry ascends the dump hill under extremely unfavourable weather conditions. ${ }^{93}$ At the top of the hill, a topographical position which pre-empts the impending power shift, he reflects on Mer$\mathrm{yl}^{\prime}$ 's list of (ten) requirements (her ten commandments) ${ }^{94}$ and her violation of her own requirements. It is this 'revelation' and the self-respect he gains with it that flip his subservient position to one of strength.

Concurrent to this celestial moment, Meryl, in the events leading to the novel's ending, is depicted in a hellish counter-scene. Despite her "attachment to Harry - to his kindness and unending patience with her, and to the love that he naturally assumed she wanted and deserved" (B. McNulty, Strange Nervous Laughter 245), Meryl gathers Harry's possession in a momentary relapse to her cynicism, piles them up in the garden, and sets them on fire

\footnotetext{
${ }^{93}$ Chapter 19 of Exodus describes the arrival of the Israelites at Mount Sinai, where Moses meets God and receives the Ten Commandments. It is striking how similar the weather conditions are to the bible passage, where the storm, the clouds, and the lightning are symbols of God's appearance to the people who are gathered at the foot of Mount Sinai.

94 The linguistic similarity between Meryl's list of requirements and the Ten Commandments also stands out. Here is Meryl's first requirement: "You must treat me well. I don't ever want to feel as if I have made a mistake, and that someone else would have been better for me" (B. McNulty, Strange Nervous Laughter 228). And here the First Commandment in comparison: "You shall have no other gods before me. You shall not make for yourself an image in the form of anything in heaven above or on the earth beneath or in the waters below" (Exodus 20.4-5).
} 
"[w]ith a derisive snort" (246). However, when the fire springs to the dead grass and Harry's house, she is trapped by the fire and is endangered.

When Harry sees the fire behind his house from the top of the hill, he makes haste to help, and the reader is left with the following closing impression:

'Meryl!' he shouted, and she looked up, wide-eyed.

For just a moment the wind died down. When she saw Harry, she smiled her secret smile, the smile she never knew existed until she met him. His hands limp at his sides, Harry smiled his secret smile.

The wall of fire blazed between them, the air was filled with sparks.

A hot rain began to fall. (248)

In light of Harry's actions, this ending can (and should) be read as an optimistic outlook. It clearly distinguishes Harry from the other characters, even heroises him. Similar to Beth, Harry does not misuse the power benefit he obtains. Rather than seeking to gain the upper hand in his relationship with Meryl, he seeks to be put on equal footing with her instead. Harry's and Meryl's "secret smile[s]" across the fire wall can be seen as a silent agreement to this position of equality, an agreement that is rewarded by a heavenly sign (in contrast to the impending diabolic destruction) and suggests the possibility of a peaceful and happy future for the two characters, even if borne out of a pile of ashes. In this regard, the apocalyptic atmosphere of the novel's ending is similar to the one in K. Sello Duiker's Thirteen Cents (discussed in Chapter 2.2), and thereby adds to its ustopian character overall, suggesting the need for a radical new start in order to overcome the encumbrances of the apartheid past.

\section{FORMAL ELUSIVENESS}

The novel is also characterised by a distinct formal elusiveness, which is reflected in its structure. Overall, the novel consists of nineteen chapters. After the robbery in the prelude, the six characters are introduced one by one in an individual chapter, before the various love stories evolve in the remaining thirteen chapters, which are either dedicated to one of the six main characters or one of the three central couples. However, what appears to be a linear account of the six main characters' lives at first glance, turns out to be a highly intricate narrative with different character entanglements and spatio-temporal overlaps. This complexity is characterised by a distinct formal elusiveness on various levels. 
The novel's temporal elusiveness, on the one hand, is reflected in the fact that its time frame cannot be precisely pinned down. The novel may set in on a Tuesday morning in October (1) and take place during the course of Durban's hottest summer (4), but temporal indications throughout the novel are generally vague and do not allow a clear chronological reconstruction of events. Instead, it appears that "[t]ime [is] stretched out like warm bubblegum" (49) and that the importance of time resolves itself in the scorching heat. Summer as the novel's time frame, placed in-between spring as the time of new beginnings and autumn as the time of maturation and the impending end, not only suggests a temporal circularity but also emphasises the summer's transitional position. This aspect of transition is also reflected in the fact that all protagonists are in their mid- to late twenties or early thirties, both a time when a young adult's life is consolidated and takes its direction as well as a time of generational transition. While the novel is characterised by a distinct intergenerational entanglement in a set of difficult parent-child relationships, it suggests a detachment of the younger generation from the older one, similar to the younger characters in Mariam Akabor's Flat 9. The parental generation generally takes a backseat, as it is either dead or not present in their children's lives..$^{95}$ Nevertheless, it makes its presence felt in the uncanny (re-)surfacing of their children's repressed pasts as the main source of insecurity and instability in the lives of the younger generation which tries to overcome the burdens of the past.

The novel's spatial elusiveness, on the other hand, is reflected in its multilinear plot structure. This not only leads to the palimpsest-like overlapping of the various plot lines but also their spatial elongation. This stretch-out is reflected in the varying chapter lengths, almost as if the sweltering heat had an influence on the elasticity of the individual chapters. In combination, this spatial overlap and extension reach for a dislocating effect with regard to the reading experience. The conscious delay of information, such as the source of Mdu's returning castration anxiety that has been discussed above, thereby gives the reader the impression of experiencing the characters' anxieties firsthand and mirrors these acts of repression or dis-placement on the level of the novel's plot structure.

\footnotetext{
95 Aisha's and Harry's parents are dead (141, 154-156). Meryl's mother dies from cancer and she has no contact with her brother Joe and her father, who left Meryl alone with her dying mother (24-25). Similarly, both Pravesh and Mdu have a difficult relationship with their parents. While Mdu breaks with them (130), Pravesh involuntarily moves back in with his parents (197).
} 
This spatial elasticity is further reproduced in the novel's narrative situation that exploits almost all available means. Generally, an unknown omniscient third person narrator dominates the narrative, i.e. the narrator renders the fictionalised world from the characters' perspectives in order to objectify the act of narration. Point of departure is thus a situation of maximum distance between the narrator and the narrative. The chapters have different focalisers, which are anticipated in the chapter headings. Each of the six main characters is assigned a different symbol - a heart for Beth, a little coffin for Pravesh, a whale for Mdu, a thought bubble in the shape of a cloud for Aisha, a cloverleaf for Harry, and a female figure wearing a tight corset for Meryl and these symbols, individually or in combination, are used as chapter headings. It is, however, less the change in focaliser(s) that deserve special mention, but the narrator's direct intervention by means of interjected comments. In these comments, which are visually set apart from the remaining narrative by three little suns before and after the interjection, the generally 'invisible' narrator surfaces. The following passage, for example, is the narrator's comment on Harry's painstaking reconstruction of his parents' life:

What is it about the human animal that simply will not let go? Oh you might like to think you're the exception; the one who has managed to walk away from all your past relationships with a clear heart, and a firm resolve.

I don't believe you for a second.

And if you have managed to walk away without pain and torn fingernails from hanging on so tightly, then I'll bet there was an Incident when you were younger that devastated you, and turned you into the unfeeling slab of marble you are today.

I understand; don't take it personally.

For the rest of us, though, there is a definite tendency to clutch onto whatever shred of the relationship is left over from the arguing, the heartache and the spite. And even if this shred is dirty, and smells funny, and is really very obviously not what we want in our lives, we reserve the right to hang on to it, and if anyone else even thinks about touching our snotty little shred of leftover love, we will injure them in any way we know how.

It's called not letting go.

Not moving on.

Being human. (158-159; my emphasis)

It is striking how the passage switches between three different pronominal forms (' $\mathrm{I}$ ', 'you', and 'we'). The use of these pronouns thereby reflects the degree of the narrator's involvement in two respects: Firstly, it establishes an axis 
of increasing involvement from general pronominal absence, which signifies no personal involvement on the narrator's part, to (1) a minimal degree of involvement by means of directly addressing the (implied) reader (you), (2) a medium degree of involvement by establishing a common ground between the (implied) reader and the narrator (we), or (3) a high degree of involvement by the narrator's exposure $(I)$. Secondly, the narrator's involvement becomes additionally 'measurable' on the basis of the concurrence of the different pronominal forms. The axis again extends from a minimal to a medium and a high degree of involvement, depending on whether a pronominal form occurs on its own or in combination with one or even both other forms. The combination of all three forms, like in the passage above, thus displays the highest degree of narrator involvement possible, which highlights both the emotional intensity as well as the implied closeness between the narrator and the narrative. Overall, the novel exploits the full range of options in these commenting interjections and the constant shifting along the near/far-axis also suggests a 'bubblegum-effect' also with regard to the narrative situation, which not only mirrors the novel's precarious character on yet another level but attests to the narrator's passion for the characters, South Africa in general, and Durban in particular.

Lastly, the novel's spatio-temporal elusiveness is echoed in its 'generic precariousness'. Reviewers have generally associated McNulty's novel - both to a greater and lesser extent - with the genre of magical realism (Machen; van Eeden), ${ }^{96}$ sometimes in connection with the humorous ("Strange Nervous Laughter"), the whimsical (Otter), or the satirical and 'chick lit' (Rosenthal). The novel's genre mix thereby has to be seen as a deliberate undermining of simplistic categorisations on a generic level. As a detailed discussion of all genre influences would go beyond the scope of this chapter, I will restrict myself to a final comment on magical realist elements in Strange Nervous Laughter, which I see as most prevalent and relevant for my discussion of the novel as an example of 'spiritual realism' instead.

\footnotetext{
${ }_{96}$ Meyer H. Abrams, in A Glossary to Literary Terms, defines magical realism as "a sharply etched realism in representing ordinary events and details together with fantastic and dreamlike elements, as well as with materials derived from myth and fairy tales", often in violation of "standard novelistic expectations by drastic - and sometimes highly effective - experiments with subject matter, form, style, temporal sequence, and fusions of the everyday, the fantastic, the mythical, and the nightmarish, in renderings that blur traditional distinctions between what is serious or trivial, horrible or ludicrous, tragic or comic" $(203,204$; original emphasis). Two extensive studies on the magical realist novel in Africa are Brenda Cooper's Magical Realism in West African Fiction: Seeing with a Third Eye and Gerald Gaylard's After Colonialism: African Postmodernism and Magical Realism.
} 
While the novel displays elements of magical realism, most obviously in the six main characters' unusual abilities, I would suggest 'spiritual realism' as an alternative framework in which to place the novel. ${ }^{97}$ The term was first introduced by Kwame Anthony Appiah in an early review of Ben Okri's The Famished Road as a deliberate distinction from South American works of magic realism. He argues that the spiritual realist world in African fiction:

is more real than the world of the everyday. And so tales of that world have, like tales of our own, their own justification. What is exciting is the energy of this rendering of the reality [...] [as] linked to, and sometimes in tension with [...] national politics. Together the spiritual realism and the moral seriousness generate heat, light, fire. (147)

For Appiah, the principal difference between magical and spiritual realism thus lies in their different orientations. While the former has to be seen in the context of anti-hegemonic and decolonising processes in favour of traditionconscious nationalist tendencies, the latter may display a distinct opposition to national policies, as Douglas McCabe poignantly differentiates (2). In Strange Nervous Laughter, this tension manifests itself in its underlying counternarrative tendencies that 'write against' the unifying 'rainbow-narrative' in order to reveal some of the complexities of post-apartheid South Africa and to illustrate different trajectories of dealing with these intricacies. The outlining of these trajectories has a distinct spiritual tenor in that the main characters can be said to be "looking inward to the Self and [more or less successfully] finding ways to free it from the anxieties and hang-ups and perceptual cookiecutters of the ego" (McCabe 7)..$^{98}$ This process of self-discovery thereby not only puts the re-negotiation of subjectivities at centre stage but also inextricably ties it to the difficulty of joining seemingly irreconcilable spatio-temporal and socio-cultural contradictions. The novel, as I have argued above, constantly plays off binary oppositions against each other in order to blur them and it

\footnotetext{
${ }^{97}$ In her work on the representation of bisexuality in post-apartheid South African fiction, Cheryl Stobie associates novels such as K. Sello Duiker's The Quiet Violence of Dreams or Ashraf Jamal's Love Themes for the Wilderness with spiritual realism. With regard to Duiker's novel, for example, she argues that "Duiker expands [the] repertoire [of black gayness], particularly audaciously through his presentation of spiritual quests finding their fulfilment through socially taboo forms of sexual expression" ("Somewhere" 131).

98 However, it should be noted that McNulty's novel does not reflect a particular set of spiritual beliefs, as McCabe argues in the case of Ben Okri's New Age beliefs.
} 
does so in favour of a general spatio-temporal openness, which is in sharp contrast to apartheid's (spatial) restrictions. ${ }^{99}$

However, the fact that the reader is left ambiguous as to the overall outcome of the individual characters' successes and failures in breaking free (of social conventions) and/or reaching self-discovery thereby lends the novel a distinctly ustopian character, though - if one considers the novel's ending, its last impression - leaning more towards the utopian end of the spectrum. In addition to the mixed outcomes of the different romantic relationships, I argued for the post-apartheid subject's overdetermination, such as reflected in the novel's title, to be distinctly characteristic of the ustopian, laughter being the novel's suggested remedy to overcome the 'strangeness' of postapartheid's new dispensation in which formerly separated racial groups are now equal members of society. The general unhomeliness of the postapartheid subject due to the shifting/shifted socio-cultural and -economic conditions, another characteristic of the ustopian, ultimately corroborates the topicality and continuation of the processes of spatio-temporal amalgamation of the apartheid past with the post-apartheid present.

\footnotetext{
99 This difficulty thereby reflects a deeper question of genre. With regard to spiritual realism, Cheryl Stobie comments: "The enterprise of melding the traditional novel with African myth poses problems to the author concerning the union of conflicting perspectives: the real and the fantastic, the secular and the spiritual, the pre-colonial past and the post-industrial present" ("Somewhere" 131). Along similar lines, though for magical realism, Brenda Cooper states: "[A]t its best [it] opposes fundamentalism and purity; it is at odds with racism, ethnicity and the quest for tap roots, origins and homogeneity; it is fiercely secular and revels in the body, the joker, liminality and the profane. I say that it can do these things, when at its best, to emphasize that it does not, by definition, do them. In reality, the novels themselves are heir to many traditions, pressures, and conflicting strategies and as such, tend to be an amalgam of politics and purposes, working at different times in the interests of different segments of different populations" (22).
} 


\subsection{LAUREN BEUKES' MOXYLAND}

Since 2000, the South Africa's literary scene has seen a burgeoning of speculative/science fiction, fantasy, and horror. Examples of authors who work within these genres are Lauren Beukes, S. L. Grey, Sarah Lotz, Lily Herne, Charlie Human, or Henrietta Rose-Innes, to name but the most prominent names. ${ }^{100}$ In view of her success, Lauren Beukes can, together with Sarah Lotz, be seen as brand leader and international poster-child in promoting innovative, genre$b(1)$ ending fiction that breaks away from South Africa's predominantly realist tradition. Questioning whether fantasy can be considered as great fiction in a contemplative article (triggered by the publication of Kazuo Ishiguro's (fantasy) novel The Buried Giant), Philippe Zweifel writes:

Classical [i.e. realist] fiction describes the discrepancy between internal and external life: how do we see reality and how do we (not) find our bearings therein. Fantasy literature turns this pattern upside down. The internal life manifests itself in a magical or surreal way - thus becoming the external life in which the characters move around, with which they have to come to grips. (52; my translation)

This principle certainly holds true for Lauren Beukes' Moxyland. The novel is set in a futuristic Cape Town where social divisions are put into effect by people's economic standing rather than according to racial markers. The city is in the hands of a number of corporate companies that rigidly police almost every aspect of people's lives. The novel is narrated from the perspective of four Capetonians in their twenties: the art school dropout and up-and-coming photographer Kendra, who becomes a brand ambassador for a soft drink called Ghost and to this effect agrees to an experimental nano-technological procedure; the avid blogger/gamer/drug addict Toby, who constantly films events around him with his techno-coat that is fitted with mini cameras and who completes paid gaming missions; the activist Tendeka, who ardently opposes the corporate regime under the tutelage of an avatar named skyward* with whom he communicates via the online virtual world of Pluslife, and who, together with his boyfriend Ashraf, runs a football club in Khayelitsha as well as

100 S. L. Grey is the pseudonym for the writing duo Sarah Lotz and Louis Greenberg, whereas Lily Herne is the pen name for the cooperation between Sarah Lotz and her daughter Savannah. Other authors who work within these genres are e.g. Louis Greenberg, Cat Hellisen, David Horscroft, Alex Latimer, Angela Meadon, Peter Merrington, Andrew Salomon, Alex Smith, Fred Strydom, and Terry Westby-Nunn. 
a graffiti programme for street children; and the gifted corporate programmer Lerato, whose sole ambition is to climb to the top of the corporate ladder.

The lives of the four protagonists increasingly overlap, and Toby (who is friends with Lerato, joins Tendeka for one of his protest actions in order to get video footage for his blog, and starts a brief affair with Kendra) is positioned as the common link between them. The more the lives of the four characters converge, the more ambiguous the boundary between (fictional) 'real places' and 'imagined places' becomes, playing the two spaces off against each other. The plot culminates in a pass protest at the (fictional) Adderley Street metro station by Tendeka and his followers that coincides with one of Toby's gaming missions/simulations to 'kill' a terrorist which goes awry when a civilian is injured. The ensuing chaos provokes the release of the deadly M7N1 virus on all people present at the station at that time, an event that has far-reaching consequences for all four protagonists.

Beukes is a trained journalist and holds an MA in Creative Writing from the University of Cape Town. She is the author of four novels - Moxyland, Zoo City, The Shining Girls, and Broken Monsters - and, most recently, a collection of short stories and non-fiction, titled Slipping. ${ }^{101}$ Her international breakthrough came with Zoo City. The novel won the Kitschies Red Tentacle for best novel in 2010 as well as the prestigious Arthur C. Clarke Award for Science Fiction in 2011, and was shortlisted for several further international and South African literary prizes in these two years. ${ }^{102}$ While her first two novels, set in Cape Town and Johannesburg respectively, have a distinct South African and local focus, Beukes' subsequent novels are both set in the United States. This change of setting, however - which was effected due to Beukes' wish to address more universal issues that she felt she could not have addressed within the South African context without her stories being subjugated to the country's apartheid past (Beukes, Personal Interview) - did not detract from the success. The Shining Girls won the 2013/2014 UJ Prize and was shortlisted for the 2014 Sunday Times Literary Prize. Broken Monsters was shortlisted for the 2014/2015 UJ Prize and longlisted for the 2015 Sunday Times Literary Prize. The success of Beukes' novels is also underlined by the fact that the film rights to three of her

101 Beukes has published a number of short stories before the publication of Slipping. "Chislehurst Mess" in Pandemonium: Stories of the Apocalypse (Perry and Shurin) and "Unathi Battles the Killer Hairballs" in Home Away: 24 Hours, 24 Cities, 24 Authors (Greenberg) are two examples, the latter of which has been included in Slipping.

102 In 2010, the novel was shortlisted for the BSFA Award and the World Fantasy Award. In 2011, the novel was shortlisted for the University of Johannesburg Literary Prize as well as the M-Net Literary Awards and was longlisted for the Sunday Times Literary Prize. 
four novels have been optioned. ${ }^{103}$ In addition to her novels, Beukes also wrote a book of non-fiction. Maverick: Extraordinary Women from South Africa's Past is a collection of vignettes on the lives of women such as Krotoa-Eva, Sara Baartman, or Ruth First, all of whom left an indelible mark on South Africa's history. The book was nominated for the Sunday Times Alan Paton Award for non-fiction in 2006. Finally, Beukes has written several graphic novels, ${ }^{104}$ contributed to Disney shows such as Mouk and Florrie's Dragons, and was the showrunner of the South African animated TV series URBO: The Adventures of Pax Africa (Lauren Beukes).

In view of Beukes' success, it is not surprising that her work has gained considerable scholarly interest. Moxyland, both on its own as well as in connection to Zoo City or as part of Beukes' whole body of novels, has been read from a range of angles. The bulk of scholarly work up to date focuses on questions of genre. The genre debate was opened by Chris Thurman who reads Moxyland as an example of 'allegorical realism' in his argument against a distinct 'post-transitional literature' ("Places Elsewhere" 99). Andries Visagie sees Moxyland as a 'critical dystopia' that represents "risk in capitalist society with particular attention to the interplay of both utopian and dystopian elements in their largely dystopian fantasies about a future South Africa" ("Global Capitalism" 98). Similarly, Cheryl Stobie argues that Moxyland is a 'critical dystopia' that unites elements of dystopia, cyberpunk, and slipstream ("Dystopian Dreams" 370-371). Eric Smith, in turn, suggests a reading of the novel as a blend between 'critical dystopia', cyberpunk, and 'post-contemporary antipastoral'. He claims that the novel "specifically addresses the virtualities and cyber-realities of late capital's globalized spaces" (172). Louise Bethlehem reads the novel as post-apartheid dystopia that melodramatically re-negotiates South African 'city-ness' (524-525) and Alexander Phoenix reads all four of Beukes' novels as 'spectacles of dystopia'. Phoenix reasons that it is "the four novels' use of digital formats" that "constitute the ostensibly familiar yet equally disturbing writing of dystopian spaces in Beukes' work" (157). Rebecca Duncan, in contrast, bemoans the fact that "critics have yet to take seriously

\footnotetext{
103 While the film rights to Zoo City have been optioned by renowned South African film producer Helena Spring (L. van Wyk), the film rights for Beukes' third novel were bought by MRC and Appian Way, Leonardo DiCaprio's production company (Kit and Lewis). In January 2015, it was announced that Endemol Studios bought the film rights to Broken Monsters and that the book is to be adapted into a television series ("'Broken Monsters' Acquired").

104 Fairest Vol. 2: The Hidden Kingdom is an example of a graphic novel by Lauren Beukes. The novel, which is a collaboration with artist Inaki Miranda, appeared as issues 8 to 13 of the American comic series Fairest in 2013.
} 
the marked presence of the gruesome, the ultra-violent and the shocking in [Beukes's] work" and suggests a reading of Moxyland (and Zoo City) as horror (86). Similarly, Mélanie Joseph-Vilain argues in favour of elements of the gothic in Beukes' work ("Un Posthumain"). In an earlier article, Joseph-Vilain's offers a more theme-based analysis of Beukes' debut within the theoretical framework of the post-human ("Corps"). Henriette Roos focuses on the figure of the artist and examines the link between artistic work and opposition in connection to their anchoring in the novel's textual strategies. Jennifer M. Schmidt also offers a reading of the artist figure Kendra but as "the 'star power' of a cool, 'effortlessly casual' white femininity [that] sustains the hegemonic power of whiteness" (110). Helen Kapstein, for her part, has read the novel both in view of the tourism industry's efforts to promote South Africa as a global tourist destination ("Culture of Tourism") as well as the phenomenon of mass hysteria that "shows us a collective indeterminacy, and the possibility of rallying against the unknowable" ("Coffins" 68). Meg Samuelson ("Sea Changes" and "(Un)Lawful Subjects"), finally, reads Cape Town's littoral zones as portrayed in Moxyland as a symbolic node that bridges the city's Company past and corporate present that speaks to the perpetual flows of capital within and through the novel's futuristic Cape Town.

It is the aim of my analysis to add to the ongoing discussion of Beukes' debut novel in light of its various hyperrealist notions by taking recourse to Jean Baudrillard's concept of the 'hyperreal' which will be examined in more detail below. The hyperreal has been used before in the novel's analysis, even if only selectively. Helen Kapstein, on the one hand, reads the release of the M7N1 virus at Adderley Street Station and the subsequent scenes of panic as a "simulacrum of hysteria" ("Coffins" 57), but does not use the concept beyond that. Eric Smith, on the other hand, rightly argues that "the novel's Cape Town is itself 'Moxyland', an already virtual world of suspended identities and flickering cybernetic subjects for which there are no stable or exterior referents, a world already fully subsumed into vertiginous hyperreality" (178). Apart from Tendeka (172-175) and Toby to some extent (177-180), however, he does not look at the main characters' involvement with the hyperreal and the implications posed by these individual dealings. In what follows, I am going to demonstrate that the novel's hyperreality is part and parcel of Beukes' critique, which goes beyond reproving the increasing dissolution of the individual in the collective (such as e.g. suggested by Eric Smith or Joseph-Vilain "Corps" and "Un Posthumain"), and pillories the post-apartheid state system as a 'South African Watergate'. This meta-criticism reaches its full weight if the 
novel's various hyperreal notions - i.e. its hyperreal setting, the effects of the novel's hyperreal setting on the four protagonists lives, and the reiteration of the hyperreal on the novel's symbolic and narrative level - are looked at in connection to each other.

\section{THE HYPERREAL}

The difference between the 'real' and the 'imaginary' is fundamental to the concept of the 'hyperreal' as promoted by the French sociologist and cultural theorist Jean Baudrillard. The 'hyperreal', according to him, is "the generation by models of a real without origin or reality", or "a radiating synthesis of combinatory models in a hyperspace without atmosphere" $(1,2)$. Baudrillard argues that all reality and meaning of present-day society have been substituted for their symbolic representations and that our current society is subjugated to a continuous simulation of reality that replaces reality itself. Waterlogged with simulations, (social) meaning is consequently rendered exchangeable and the distinction between the 'real' and the 'imaginary' becomes obsolete. Neither reproduction or duplicate, nor caricature, the simulations turn into 'simulacra', i.e. copies without an original (6), that have the function of obscuring the fact that the 'real' is meaningless and has been replaced by what Baudrillard calls "the precession of simulacra" (1), i.e. "the orbital recurrence of models and [...] the simulated generation of differences" (3).

In order to fully grasp Baudrillard's complex concept of the hyperreal, which lies at the basis of his social understanding, it is necessary to understand his perception of how the 'real' and the 'imaginary' are related. Baudrillard explains this relation by thinking 'simulation' through its opposite 'dissimulation'. While 'dissimulation' "is to pretend to not have what one has", 'simulation' means "to feign to have what one doesn't have" (3). Using the simulation of an illness by way of illustration, he argues that in contrast to simulation, which dismantles the distinction between the real and the imaginary, dissimulation retains the reality principle. To pretend to be ill can easily be achieved by remaining in bed and informing people about one's alleged illness. However, to feign (to simulate) an illness goes a step further and additionally implies the 'production' or 'faking' of certain symptoms in order to render one's illness (more) believable. The act of simulation thus jeopardises the import of the real. The simulator can be treated as neither ill nor healthy and Baudrillard accordingly concludes: 
For if any symptom can be 'produced,' and can no longer be taken as a fact of nature, then every illness can be considered as simulatable and simulated, and medicine loses its meaning since it only knows how to treat 'real' illness according to their objective causes. Psychosomatics evolves in a dubious manner at the border of the principle of illness. (3)

To simulate an illness thus implies an emptying of meaning that, at some point, makes it no longer possible to distinguish the real illnesses from simulated ones, as the distinction between the real and the imagined is rescinded.

It is with this understanding of simulation and the resultant removal of the opposition between the real and the imaginary that I would like to turn to the novel's setting, which, because of its topography and topology of extremes, could be labelled as ustopian and is linked to a number of distinct hyperreal qualities which will be discussed in what follows.

\section{CAPE TOWN, 2018: ‘GHOST(Ly) CiTY'}

Moxyland is set against the backdrop of an imagined Cape Town in the year 2018. The city has a strict legal system and is in the firm hands of a number of corporate companies. The influence of the city's corporations can be seen in the companies' aggressive advertising strategy, for example. The cityscape, Tendeka explains, is marked by the omnipresence of "blaring logos and adboards" that are "squatting" on buildings "like parasites" (Beukes, Moxyland 32). One of Communique's billboards on the N2, Tendeka points out, is "playing out various vignettes featuring unobtainable crap" (87) and while it "is facing the traffic coming from town" at night, "it'll swing round to face the incoming commute, like a sunflower turning towards the light" in the morning (88). The constant feed of new promotional pictures amounts to a perpetual over-writing (and thus exchange) of meaning, a "precession of simulacra" in the most Baudrillardian sense (1). Placed in full view, the oversized billboards are designed to maximise corporate consumerism, while the advertised products are "unobtainable" for non-corporate members such as Tendeka (Beukes, Moxyland 87). As such, the corporations' aggressive advertising strategy constitutes an 'overstatement', as it has a concurrent simulative and dissimulative function. While the adboards simulate the availability of consumer goods to all Capetonians alike, they dissimulate the actual socio-economic disparities between corporate and non-corporate citizens. At the same time, the corporations' advertising strategy is a case in point for the dissimulation of the deeply 
ingrained socio-political collaboration between the corporations and the government. Lerato, the corporate-climber, recognises the government as "a big Communique contract" (237), Communique being the company Lerato works for. The partnership between the government and the corporate companies is indeed so closely knit that the private and the public sector become indistinctive. Such a dissolution of the private and the public, i.e. the "collapse of [...] two traditional poles into each other" (Baudrillard 31) - which is reminiscent of the city improvement districts in connection to the revitalising initiatives in Cape Town's CBD and the controversy surrounding the enforcement of security measures by private contractors, particularly concerning the removal of informal traders from the CBD discussed in the Introduction - is a typical characteristic of the hyperreal.

This corpo-governmental franchise thus rules the citizens of Cape Town as bodies available for purchase. The extent to which the corporate promotional scheme invades the characters' private sphere also becomes evident from the "literal viral marketing technique" of the Ghost sponsoring programme (Kapstein, "Coffins" 54). In order to promote the soft drink, twelve artists - all of them "[y]oung dynamic, creative, [and] on the up" (Beukes, Moxyland 5) - are contracted as brand ambassadors and injected with an experimental nanobot-cocktail. While the nanotechnology makes them immune to diseases, it also makes them addicted to Ghost and leaves them 'branded' with a fluorescent, green tattoo of the corporation's logo. In accordance with the brand ambassadors' function as living advertisements, the logo appears at different places on test subjects' bodies in order to guarantee maximum visibility. The programme's marketing strategy is thus designed to warrant a rapid spread of the soft drink from within Cape Town's hipster market. The branding of bodies and embodiment of brands, which Alexander Phoenix rightly describes as one of the trademarks of Beukes' works in general (162), is thereby yet another salient example of how the public domain increasingly invades the characters' private space in Moxyland. The importance of the commercial success of the Ghost sponsoring programme at the expense of the bodies of the volunteers is fundamental to the portrayal of Cape Town as a 'Ghost(ly) City' dominated by the corpo-governmental (super)structure.

Cape Town's 'ghostly' manifestation is furthermore characterised by an outsourcing of nature, which is placed at the service of the city's functionality. There are "rows of filter trees lining Vukani's driveway, sucking up sunlight and the buffeting wind to power the building", but "[y]ou don't see filter forests much" because "[t]hey're too expensive to maintain outside the corporate 
havens" (Beukes, Moxyland 3). ${ }^{105}$ There are "tide drives that levelled [the ocean] off and kept the hover trains running" (87) and the city's underway, which "shushes through the tunnels on a skin of seawater, overflow from the tide drives put to practical use in the clanking watery bowels of Cape Town" (1). There is, in fact, a distinct "denaturisation of space" at play in Moxyland (Joseph-Vilain, "Corps" 167; my translation). Instead of green spaces, it is skyscrapers, luxury apartments, and lofts (Beukes, Moxyland 36, 82-83), and rotating apartments and bars $(53,142)$, as well as the omnipresence of corporate billboards which dominate the cityscape. The predominance of concrete, tar, and glass in the city's architecture lend it a distinctly impersonal appeal. The prevalence of such "a hyperspace without atmosphere" is yet another distinctive characteristic of the hyperreal (Baudrillard 2).

Similarly, the generally unfavourable weather conditions in Moxyland which are limited to rain and wind ${ }^{106}$ and which are in contrast to Durban's scorching heat in Bridget McNulty's Strange Nervous Laughter, for example add to Cape Town's 'ghostly' character. At the beginning of the novel Kendra observes: "Through the floor-to-ceiling windows [...] the southeaster bunches and whirls the clouds over Table Mountain into candyfloss flurries. Spookasem in Afrikaans. Ghost's breath" (5). I have mentioned Cape Town's (in)famous Southeaster, which is generally responsible for the peninsula's nice weather and the so-called 'Table Cloth', in connection to Rozena Maart's Rosa's District Six in Chapter 1.2. Sometimes, however, the South Easter comes as a combination of strong winds and heavy rains. The 'Black' Southeaster, as it is referred to in its more vicious form, can cause severe flooding, particularly in low-lying areas (Hepworth). It is ironic that Kendra nicknames the South Easter "Ghost's breath" (Beukes, Moxyland 5) and thus establishes a connection between the soft drink, her function as one of its brand ambassadors, and the prevalent unfavourable weather conditions in the book. In fact, the (Black) South Easter and its different levels of impact - from alleviative to destructive - become a herald of the system's 'ghostly' (omni)presence and means of control that are mercilessly set in motion if deemed necessary. Particularly the repeated references to rain throughout the novel pre-empt the government's release of the M7N1 virus in form of a 'chemical rain' at Adderley (Street) Station in response to the escalating pass protests by Tendeka and his followers. The pro-

\footnotetext{
105 Vukani Media is the name of the corporation that administers the Ghost sponsoring programme.

106 While references to rain are to be found on pages 58, 82, and 214-215, Cape Town's windy weather is mentioned on pages 3, 5, 124, 187-189, and 214-215.
} 
cedure is, as Louise Bethlehem points out, reminiscent of the purple dye that the South African security forces used in the anti-apartheid protest in Cape Town on 2 September 1989 in order to identify and arrest protestors later on (529). It is noteworthy that wind and rain are generally referenced separately. Only after the government's release of the M7N1 virus (and only once), when Kendra notes that "[i]t's drizzling" and that "[t]he wind is cold as teeth" (Beukes, Moxyland 214), are they mentioned in connection to each other. The combination of these two weather elements, which sets up the narrative's climax on a symbolic level, bespeaks the severity of the release of the virus and the far-reaching consequences for the various characters.

Cape Town's 'ghostly' outward appearance is thus characterised by the omnipresence of billboards as well as the city's 'denaturisation' and inauspicious weather conditions. All three hyperreal characteristics add to the fictional(ised) city's ustopian character and are also reflected in its topological conditions, i.e. its legal foundations and their impact on individuals. During one of his chats with Tendeka, skyward* explains that Cape Town's corporations maintain a system of rigid online surveillance of the city's population by "building social controls and access passes and electroshock pacifiers into the very technology we need to function day to day, so you've got no choice but to accept the defuser in your phone or being barred from certain parts of the city because you don't have clearance" (119). It is striking how skyward*'s comment unites seemingly adverse aspects of connectedness and separateness, which form the paradoxical basis of social life in Moxyland. This implosion of (binary) opposites once more corroborates the novel's hyperreal setting (Baudrillard 31), even if this time on a more structural level. Conformity is the ideal and legal transgressions are reprimanded severely. While minor misdemeanours lead to electroshocks 'defused' by people's phones, more serious offences lead to a 'disconnection'. In this regard Toby observes: "You can't play nice by society's rules? Then you don't get to play at all. No phone. No service. No life" (Beukes, Moxyland 21). Online connectedness, particularly by means of people's mobile phones, is thus a basic necessity in order to exist within the novel's futuristic Cape Town. Joseph-Vilain pointedly observes that the mobile phone turns into "a genuine prosthesis" such that it becomes "an integral part of characters' identity" ("Un Posthumain" 78; my translation). Besides their punitive function, mobile phones serve not only as a means of payment but also as a form of identification by which people's movement within the city is regulated. 
Digital access passes, reminiscent of the Pass Laws during apartheid, are uploaded to people's phones and their mobility is regulated to the extent that their mode of transport is affected. At the beginning of the novel, Kendra notes that her pass "isn't valid for walking rights, so Andile has arranged an agency car, already waiting for [her] on the concourse" (Beukes, Moxyland 3). She has what could be described as a 'single entry pass' with restricted mobility within the corporate domain, "[o]nly allocated for the day, to get me in and out again" (1), as Kendra clarifies. The general undesirability of (leisurely) walking, particularly in public spaces, also becomes evident in Tendeka's following comment, which establishes driving as a corporate privilege:

The loft dwellers are all locked away. All the stuff they need is inside, cafés and laundros and private gyms, so they go direct from garage to apartment, never venturing out on the street unless it's in the security of their cars. (82-83)

Overall, the novel's topological conditions corroborate its ustopian character as certain population groups become a 'ghostly' presence within the novel's fictional(ised) urban world. The novel's system of transportation thereby incorporates an essential aspect of post-apartheid South Africa's socio-economic realities into the novel, namely the correlation between modes of transportation and people's accessibility to the city. The country's system of transportation offers the problem of disadvantaging economically less privileged people, both in their mobility as well as their access to places of entertainment such as shopping malls (see Introduction).

Cape Town's 'ghostly' legal foundations are reiterated in the city's fictional(ised) topographical layout that experiments with, and exploits, the vertical and horizontal spread. By doing so, the novel plays yet another set of (binary) oppositions against each other and ultimately implodes them and their meaning(s), very much in the spirit of Baudrillard's notion of the hyperreal (31). Cape Town's vertical imaginary is expanded not only by furnishing the city with an underway system but also by the introduction of different types of housing that include so-called "subterrs", i.e. residences beneath the surface:

The counter is already looking frayed, the plastic peeling, even though the subterr is only a couple of years old. The whole thing makes me [i.e. Kendra] depressed, but Mr Muller likes to joke that he's just in touch with his body. It's dragging down with age, so he's moved below ground to keep up with it. 'This 
way, they won't even have to bury me,' he says. 'Just lock the door and be done with it.'

Of course, he's joking. The property in this neighbourhood [i.e. District Six] is far too valuable, even the swivels and subterrs. (Beukes, Moxyland 74)

The 'overpopulation' of District Six alluded to here is reminiscent of the neighbourhood's growing population density from the second half of nineteenth century onwards, a development which contrasts its later destruction in the 1970s. Moxyland plays with these historical circumstances, suggesting a densely populated neighbourhood where in reality there is a "desolate wasteland" (M. Murray, Commemorating 111) that reminds of the forced removals under the apartheid regime and the neighbourhood's demolition. The novel's 're-writing' of the District's history is another instance of dissimulation according to Baudrillard's understanding of the concept. Picking up on actual plans of redeveloping the area by the oil company BP in 1986 that were thwarted by the Hands Off District Six campaign (Soudien), the novel's suggested 'alternate history' of District Six over-writes the neighbourhood's destruction after the forced removals. At the same time, this (imaginary) redevelopment simulates the neighbourhood's enhancement in value by a general shortage of urban space in Moxyland, thus cleverly overturning South Africa's spatially fraught history. The living conditions further underline the fact that the sustainability of living space outside the corporate domain seems to be neglected in favour of maximum profit. This tendency is corroborated by Toby's home, which is "designed to maximise space" (Beukes, Moxyland 53) and thus, indirectly, also to increase profitability. In upholding a topography and topology of contrasts that opposes a corporate world to a non-corporate counterpart, the novel's corpo-governmental (super)structure feeds the (world) capitalist system on the basis of pseudo-moral and -political, and thus hyperrealist, principles. To borrow Baudrillard's argument: "capital, immoral and without scruples, can only function behind a moral superstructure, and whoever revives this public morality [...] works spontaneously for the order of capital" (14). It is the dissimulation of this very principle that, according to Baudrillard, lies at the heart of (modern) political scandals (see third section).

The functionality of the city's below - not only as 'storage' for part of its non-corporate population but also as a conduit to regulate the city's traffic flow - finds its counterpart in the corporate world's elevation. The shabbiness and complete invisibility of Mr Muller's subterr, for example, is contrasted with the corporate world's luxury and (best) view of/in the city, the "playing 
on the opposition of seeing and being seen" (or not seeing and not being seen) being another manifestation of the hyperreal (in) Moxyland (Baudrillard 29). Lerato, for example, takes pride in having an office with a sea view on the twenty-third floor (Beukes, Moxyland 95). Similarly, she admits to the "obscene satisfaction" she gains from the fact that she lives "one floor above [Mpho]" (47), a co-worker with whom she is romantically involved.

While the corporate world dominates the city's visibility, the noncorporate world is restricted to virtual representations of visibility in order to resist the city's complete invisibility:

He's [i.e. Mr Muller] got his wall2wall set on Karoo; pale light over scrub hills complete with a windpump, metal blades turning idly in a breeze you could almost convince yourself you felt. It's an idealised version of the Rural, peaceful, as far removed from the real thing as you can get. (73)

However, Mr Muller's wall2wall is not limited to a purely aesthetic function. It also confirms the horizontal dimension of the fictional world's topography that opposes a sterile and technocratic but healthy and functional Cape Town to a diseased Rural that is dominated by poverty and people who are "sick as well, or, worse, trying to escape being sick and bringing it [i.e. the superdemic] in with them from the Rural" (36), as Tendeka opines. ${ }^{107}$ The wall2wall and its "idealised version of the Rural" (73) thus become a nostalgic placeholder of a bygone era that is just as impalpable as a comprehensible reconstruction of its downfall. "When the real is no longer what it was", Baudrillard posits, "nostalgia assumes its full meaning. There is a plethora of myths of origin and of signs of reality [...]. [Nostalgia as an e]scalation of the true, of lived experience, resurrection of the figurative where the object and substance have disappeared" (6-7). This certainly holds true for 'the Rural' in Moxyland, information on which is restricted to little snippets scattered throughout the novel. This spread along the storyline not only almost eclipses the Rural and its past from the narrative's hyperreal present but it also emphasises the horizontal dimension of the novel's highly fragmented social topography on the level of its narrative-space/time. To borrow Baudrillard's argument again: "this is how simulation appears [...] - a strategy of the real, of the neoreal and the hyperreal that everywhere is the double of a strategy of deterrence" (7).

At the same time, the division into "a world of two velocities" (Joseph-

107 The superdemic, which is only referenced on three occasions throughout the novel (36, 231, 255), is an obvious analogy to South Africa's HIV/AIDS pandemic of the late 1990s and early 2000s. On the pandemic see e.g. Abdool Karim and Abdool Karim or Rohleder et al. 
Vilain, "Corps" 168; my translation) picks up on what can doubtlessly be regarded the two most prominent tropes within South African literature: the (sickly and declining) rural and the (evolving) urban. The literary reflections on the conflict between the rural and the city found their beginnings in the South African plaasroman (farm novel) of the early twentieth century in the works of writers such as D. F. Malherbe and C. M. van den Heever (Heywood 120-121; see also Coetzee White Writing). It is, however, in the 1930s and 1940s and the 'Jim comes to Joburg'-genre that the conflict was to culminate. Johannesburg, such as represented in the works of Peter Abrahams and Alan Paton, was to become the archetype of the urban Januform 'beast' as both a place of success as well as (personal and communal) destruction (122). The "pilgrimage motif" with the migrating rural labourer who seeks success and prosperity in the city at its centre, Heywood emphasises, "takes us back along a continuous literary chain to the origins of literature. The chain leads backwards in time from Bunyan's Pilgrim's Progress to Apuleius' The Golden Ass and tales of suffering and release such as the ancient Egyptian tale 'The Eloquent Peasant'" (123).

Moxyland can be seen as both a 'writing back' to and 're-writing' of this conflict between the rural and the urban. Johannesburg may have been substituted with Cape Town, but the country/city-dichotomy, even if the rural is marginalised as mentioned above, is still at the basis of the (city-)state's legitimisation. The 'pilgrimage motif', however, is detached from its rural origin and restricted to the urban sphere. At the centre of the narrative are the four narrators' symbolic journeys in search of their place within the technoconsumerist city, a journey in which the key issue circles around their (in)ability to distinguish the real from the imaginary. Below I discuss more character-based notions of the hyperreal and their impact on the lives of the novel's four protagonists. In doing so, the following section highlights the projection and internalisation of Cape Town's hyperreal topography and topology onto the various characters' psyche. Each of the four protagonists can ultimately be seen as another form of embodiment of the hyperreal. Seen as types, each of the hyperreal characters become a further quality of the ustopian city(-state) (in) Moxyland.

\section{Ghost Girl Kendra}

In Kendra's view, "things are only real if they are documented, if there is visual evidence" (Beukes, Moxyland 124). This understanding of reality is inextricably linked to her preference for analogue photography. "[F]ilm", she ex- 
plains, "is more interesting than digital. There's a possibility of flaw inherent in the material. [...] some of it has rotted or it's been exposed even before I load it in the camera, but I don't know that until I develop it" (161). The medium's imperfections and unpredictability as well as the possibility "to be involved in the process" (75) of the pictures' development are a counterpoint to the 'ghostly' digitalisation and subsequent dehumanisation that dominate the novel's hyperreal/ustopian fictional(ised) present.

The implicit "anti-essentialist aesthetic" of Kendra's photography (Schmidt 111) is in stark contrast to her involvement in the Ghost sponsoring programme. Her subscription to the programme involves both an element of acute awareness and utter naivety at the same time. While her motivation to become a "Ghost girl" (Beukes, Moxyland 1) is clearly goal-driven and based on the nano-tech's immunosupportive properties, her fascination with the nano-tech's anti-aging effects has a more naive component. For as aware as Kendra is of the nano-tech's enhancing properties, as oblivious she is to her own 'objectification' and 'eroticisation' in her function as a living mannequin for Ghost (at least partially), and as ignorant she is towards the imminent dangers of the soft drink's long-term effects. It is only upon Toby's insistence that Kendra becomes self-reflexively involved:

'I feel like everyone's watching me,' she confesses.

'Of course they are. You're splinter-new, novelty deluxe. And the burning question on everyone's lips is, what does it feel like?'

'Like taking drugs?'

'That's probably the most generic description I've ever heard. I'm not buying that.'

'Okay, okay.' She laughs, openly, warmly, very hot. 'I'm just... improved. It's like, everything's running better, like I've had a tune-up, you know? The world seems sharper. Or fiercer. As if someone's pulled the focus. Like in photography, hyper-realism?' She catches my blank look. 'Where everything is intensely real. It's super-defined.'

'Sounds hectic.'

'Yeah. Although, you know, I'm not entirely convinced I'm not imagining it.' (25)

In her comparison of the soft drink's consumption to "taking drugs" as opposed to the portrayal of its effects with a whole number of positive linguistic markers such as comparatives ("better", "sharper", "fiercer") and upgrading pre- and suffixes ("hyper-realism", "super-defined", "tune-up"), the funda- 
mental polarity of Kendra's character is reflected. Umberto Eco argues that "[w]e can identify [hyperreality] through two typical slogans that pervade American advertisement. The first, widely used by Coca-Cola but also frequent as a hyperbolic formula in everyday speech, is 'the real thing'; the second, found in print and heard on TV, is 'more' - in the sense of 'extra'" (7-8). Despite the fact that Eco's remark concerns America in the early eighties, it can be applied more generally. Both 'real' and 'more', besides the repeated use of comparatives and upgrading pre- and suffixes, are frequent linguistic markers in Moxyland that help to establish the fictional(ised) world's hyperreality.

The combination of drug (ab)use with health-promoting properties in her description speaks to Kendra's (mental) instability and her difficulty to assess, and adapt to, the diverse situations she is confronted with after the nano-tech injection. Both healthy and sick at the same time, Kendra thus turns into the personification of the hyperreal. This hyperreal status is again reflected in her doubts of Ghost's positive effects, which not only raise the issue of the distinguishability between reality and imagination in the most Baudrillardian sense, but also question Kendra's notion of reality. It is ironic that she compares Ghost's effects to hyperrealist photography when, in fact, the sponsoring programme goes against the very concept of reality that Kendra establishes and pursues with her photography. While she wishes to 'document' the effects of the nano-tech, she can only do so superficially: "If only I could embed a camera inside my body, I would. But all I can do is document the cells mutating on the inside of my wrist, the pattern developing, fading up like an oldschool Polaroid as the nano spreads through the system" (8). Kendra's record is thus "at best a symptomatic reading," as Eric Smith argues, "of a much more profound, subdermal event that can be represented only by the void, by the negative acknowledgement of the unseen" (179).

The polarity and imbalance of Kendra's character is also reflected in the centrepiece of her exhibition, called Self-Portrait. Self-Portrait is "a print from a rotten piece of film" that "came out entirely black" (66) and picks up the issue of (in)visibility as it questions the very concept of the documentability of things and thus of Kendra's conception of reality. Kendra later on adds to the background of the picture when she explains that: "under the black of Self-Portrait is a photograph of a photograph, clutched in my fingers, captured in the mirror with a reflected flash of light" (164; original emphasis). The film's imperfection thus renders the real, which is hidden or lost behind the photograph's blackness, un-documentable. Instead, the imaginary of what was pho- 
tographed becomes the new real, the hyperreal, and the print, already a miseen-abyme, turns into a double mise-en-abyme.

The wheel comes full circle with Kendra's death. After her exposure to the M7N1 virus, Kendra ends up with Toby with whom she spends the night (220-227). The next morning, the two set out in search of a phone but split up after a fight (248-249). Being refused help by Mr Muller (252-256), she manages to contact Damian and ask him to drive her to Inatec in order to be injected with the antidote (261-265), however the antidote turns out to be a lethal injection instead. It is the ambiguity of Kendra's character that turns out to be her undoing and Kendra's photography ultimately turns into an involuntary (self-)representation of her hyperreal status.

\section{Radical(ised) Loser Tendeka}

Tendeka's relation to, and dealing with, the hyperreal are inextricably linked to Pluslife, a virtual world reminiscent of Second Life, ${ }^{108}$ where he meets the anonymous avatar skyward* with whose help he plots his protest activities. His virtual home is called Monomotapa and is situated in a place called Avalon, both mythologised 'heavenly' places that befit Tendeka's idealism. The neighbourhood is "a re-creation of the LA hills" including avatar celebrities en masse which leads to competitions among users measured by "who's keeping it more real" $(39,40)$. However, it goes against Tendeka's idealism to indulge in such vanities, which is why he opts for the "more honest" option and "just uploaded a photograph and skinned it direct to [his] avatar" (39).

Eric Smith convincingly argues that Tendeka's home "represents for him both a kind of secure depository for and concrete expression of his deepest utopian longing" (172). Tendeka's idealism, Smith further claims, thereby contrasts the virtual environment to which he is restricted to act out his vision (173). Monomotapa, the name of Tendeka's home, evokes the controversial history of Mutapa, a powerful tribal leader of the fifteenth century who allegedly ruled over a kingdom encompassing extensive parts of southern Africa (see e.g. Randels). According to Smith, Monomotapa is "an historicist impasse", as "either Monomotapa did exist as a bloodthirsty empire that drove out Christianity and, with it, civilization, or it was an elaborate bugbear born of equal parts xenophobic dread, ideological expediency, and imperialist romanticism". Smith concludes that while Tendeka's awareness of Monomota-

\footnotetext{
108 Second Life, which was developed by Linden Lab and was released in 2003, is "the pioneering virtual world that's been enjoyed by millions of people and seen billions of dollars transacted among users in its economy" ("About Linden Lab"; for more information see e.g. Au).
} 
pa's history and its signification is deliberately left unclear, the "idealized primal past" that his virtual home may suggest is a direct product "of the imperial imaginary and its conquest of Africa", the same way Tendeka's opposition to the corporate system is in fact self-induced by the system in order to sustain its functionality (174).

It stands to reason that Smith subsequently identifies the LA of Pluslife as an electronic simulation that is, in fact, already a pure simulacrum. Following Baudrillard's argument regarding the relationship between Disneyland and LA (12-13), he reads Pluslife as an imaginary with the function to convince its users of the non-virtual world's reality, while that reality itself becomes hyperreal (E. Smith 174-175). Beukes' Cape Town is thus "no longer anything but an immense scenario and a perpetual pan shot" for which the imaginary of Pluslife, at least in Tendeka's case, is "like a sympathetic nervous system made up of childhood signals and faked fantasms", "a space of the regeneration of the imaginary" (Baudrillard 13).

What Smith, however, does not note is the fact that Pluslife is also the place of Tendeka's isolation and radicalisation, which are reflected in the mythology evoked by Avalon, the name of the neighbourhood in which Tendeka's virtual home stands. Avalon refers back to the Arthurian legend such as recounted in Thomas Malory's famous historical romance Le Morte d'Arthur. The island Avalon is where King Arthur's sword Excalibur is forged and where the fatally wounded Arthur is taken after the Battle of Camlann (XXI.27). The Arthurian legend professes a chivalric code of honour and the knights' devotion to King Arthur and the fellowship of the Round Table. These legendary chivalric ideals are reflected in Tendeka's marriage of convenience with the pregnant Malawian refugee Emmie (Beukes, Moxyland 29), his graffiti programme for street children that he sees as "a way of letting them make a mark on the city that usually filters them out like spam" (32), or the fact that he rigorously opposes the financing of his graffiti programme with corporate money (33). However, Avalon's insular nature also mirrors Tendeka's social isolation as well as his increasing conflict with, and distancing from, his boyfriend Ashraf. Finally, while Avalon is the alleged place of origin of King Arthur's sword Excalibur, Tendeka's teaming-up with skyward* in virtual Avalon equals his symbolic armament and his growing radicalisation throughout the novel. At the same time, Avalon is reminiscent of the Avalon cemetery in Johannesburg where a number of anti-apartheid activists such as Joe Slovo, Lilian Ngoyi, Helen Joseph, and Hastings Ndlovu are buried and thus also pre-empts Tendeka's tragic death. 
It is against this background that I would like to suggest a reading of Tendeka's character as a 'radical(ised) loser' in which the hyperreal manifests itself. According to Hans Magnus Enzensberger, the radical loser is a figure of isolation and disillusionment in search for a compensation of (personal) deficiencies, a process that can lead to terrorist action if the radical loser finds a way out of his isolation and finds empowerment within a collective. Enzensberger argues that:

With the way humanity has organized itself - 'capitalism', 'competition', 'empire', 'globalization' - not only does the number of losers increase every day, but as in any large group, fragmentation soon sets in. In a chaotic, unfathomable process, the cohorts of the inferior, the defeated, the victims separate out. (sec. 1)

Tendeka's disappointment, which is directed at the corpo-governmental system, can be seen as the sum of numerous little losses such as the Italian financiers' withdrawal from the graffiti programme due to the programme's ostensible lack of sustainability (Beukes, Moxyland 33). Each loss adds to Tendeka's social separation and feeling of disenfranchisement, also reflected in the location of his home-place outside of Cape Town's city bowl, which drives him to Pluslife and its virtual world and into the arms of skyward*. It is in skyward* that Tendeka finds his collective body and becomes radicalised. The latter becomes apparent in statements such as Tendeka's explanation that "before skyward*, we were Disney channel, strictly kid's stuff" (38) as well as the changes in his activist actions. Starting on a relatively harmless level with the smearing of an adboard (87-93), they find their continuation in Tendeka's violent destruction of a genetically modified art installation of one of Kendra's coexhibitors (165-171) and the pass protest that escalates to Tendeka massacring a number of police dogs and the subsequent release of the M7N1 virus (190213), and culminates in Tendeka's bombing of an immune centre (234-236). The "ideological detonator" that, according to Enzensberger, "is required to ignite the radical loser and make him explode" (sec. 2) can be found in the chat between skyward* and Tendeka shortly before the latter crashes Kendra's exhibition. It is during this conversation that Tendeka is pushed to the realisation that he is "not doing enough" (Beukes, Moxyland 119) and that skyward* declares the city "a communication system" that needs to be taught "a new language" (120), the language of terrorism.

In Tendeka's case, the hyperreal is essentially based on aspects of (mis)information. Blindly following his mentor skyward*, Tendeka does not 
detect the warning signs. Finding his enviro-friendly virtual home replaced by tin shacks (114) does not trigger Tendeka's suspicion, just as he does not question how skyward* knows where to send the new phone he receives following his 'disconnection' after the release of the M7N1 virus (229). Having fully 'incorporated' skyward”'s hyperreal anti-corporate doctrine, Tendeka's destiny takes its course. Infected by the virus, Tendeka's health quickly deteriorates. Unable to distinguish reality and imagination any longer, Tendeka dies in the illusion of a heroic death out in the open. He literally dissolves on top of the roof of Toby's apartment, the whole incident being filmed by Toby. Tendeka's character is thus, like to Kendra, another personification of the hyperreal that, in its radicalised version, is undesirable to the corporate world and is consequently eliminated or rather 'dis-corporated'.

\section{Career Girl Lerato}

In contrast to Kendra's naivety towards the implications of her status as Ghost's brand ambassador, Lerato displays a conscious awareness of the apparent pressure, particularly on women, to succeed in corporate life within a particular time frame or to face stagnation instead. Seemingly unimpressed by the multiple pressures that the intersection of her personal background as an orphaned AIDS child, her high aspirations, her inner biological clock, and the social expectations put on the female body, Lerato adjusts to the book's fastpaced, goal-driven, techno-consumerist hyperreal urban world.

It is Lerato's recklessness in transgressing the line between legality and illegality that sets out the characteristics of her personal (hyper)real space within which she operates. These indiscretions have both a serious and ludic component. When Lerato agrees to disarm the security on the N2 Communique adboard in order to assure Toby's contribution to Tendeka's smearing campaign (56-57), she seems to be doing him a favour. Her contribution, however, turns out to be pure calculation, as Lerato later on clarifies:

I'm expecting a tech support call-out any minute to deal with a damaged adboard. I stayed up all night coding upgrades with some neat little added features of my own for the security software they're going to have to install today, and then covering my tracks to ensure it looks like they've always been there. (97)

Lerato's involvement in Tendeka's protest action is thus far from selfless but part of her career advancing plans. Her tightrope walk remains unimpeded until Tendeka's bombing of the immune centre. Recognising the attack as 
Tendeka's doing, Lerato tries to erase “the sticky fingerprints he's left over everything" (239) on her phone using a fake SIM. This is when she stumbles across one of Tendeka's message to skyward* that mentions both her and Toby by name. Tracing the IP address of skyward*'s email address, she finds out about Communique's involvement in the terrorist attacks (241), albeit too late to cover her own connection to Tendeka. Her roommate Jane, who turns out to be a spyware controller with Communique's internal affairs (243), is already waiting for Lerato in order to escort and interrogate her.

There is, similarly to Kendra's case, a bitter-sweet irony as the circle of Lerato's story is completed. Jane's proof against Lerato is hidden in her recordings of Ángeles de la calle (i.e. Angels of the Street), the Mexican soap opera she likes 'watching' (272), which again mixes up imagination and reality in the most Baudrillardian sense as Lerato's life turns into a veritable soap opera and the proof hidden in the soap opera's recordings have an imminent impact on Lerato's reality:

'Let me lay it out for you Lerato. You keep your job. Things carry on exactly as per normal. Three months from now, you will be transferred to Mumbai, into another department. Your contact with your former co-workers and Zamajobe and Siphokazi [i.e. Lerato's older sisters] will dwindle away. You'll be too busy to correspond, and within a couple of months, they'll stop bothering. It's not like you have any meaningful relationships anyway.'

$[\ldots]$

'[...] You'll be running several identities, posting, inciting, organising whatever's required. Let's say you're on the up. Heading skywards.' (281-282)

Lerato's deeply rooted double standards due to her early inclusion into the corporate foster system that taught her "how to play the system" (134) and her loose family ties make her the perfect candidate to become another skyward*. The depth of her duplicity is notably emphasised as she literally 'incorporates' of the fake SIM she uses to eliminate the traces of her connection to Tendeka by putting it "as deep as it will go into [her] cunt" (242) after uncovering the system's corruption. Lerato's absorption into the corporate counterterrorism unit thus turns Lerato into an 'angel of the street' and in her new function as corporate avatar she becomes yet another embodiment of the hyperreal, both real and imaginary, good and bad, visible and invisible.

\section{(Arch-)Opportunist Toby}

Similar to Tendeka, Toby's involvement with the virtual world shapes his relation to the hyperreal. In order to bypass the shortage of money after his par- 
ents decide to cut him off his trust fund (13), Toby plays video games for money. For this purpose, Toby goes to see Unathi who gives out gaming missions on commission (72). Kiwi Pop, a children's game, is his first task. It is the game's mascot by the name of Moxy, which appears on the original cover of the South African edition published by Jacana (see Figure 13) and which Toby describes as "a dino-beastie thing with a toothsome grin and beady black eyes" (72), that gives the novel its name. ${ }^{109}$ While the mascot's outside appearance suggests a cosy, child-friendly fun-world, the virtual reality looks decidedly different. As soon as Toby enters the game he is attacked by Fluffoki and her friends and is killed (104-105). Overwhelmed by the situation, he calls Lerato for help, who reroutes his IP address to make it look like Toby is reentering the game from a different location (105). Once Toby has solved his mission he brags:

Trophy in paw, I invest another hour twenty backtracking to find my original spawn-in spot, and reduce Fluffoki and her little friendlings to so much dead flesh, although sorry to say, it being a kids' game, they die in splatters of sparks rather than bloody gibs. (106-107)

It is worth noting that in its slightly different spelling variation 'moxie' signifies "courage, audacity, spirit; energy, vigour; enterprise; skill, shrewdness" (Oxford English Dictionary). The word originates from the mass-produced carbonated beverage Moxie that enjoyed great success in the United States particularly in the 1920s and entered the English language due to the soft drink's extensive brand advertising. In the late 1920, the company opened a big manufacturing and distribution centre by the name of 'Moxieland' in Roxbury, Boston (Moxie). Toby's revenge on Fluffoki and Co not only shows that he has got the 'moxie' to complete his gaming missions, but it is also a (digital) harbinger of Tendeka's gruesome death, which Toby is to observe at the end of the novel, and ultimately his ability to survive in the corpo-governmental system.

The games, however, are just one opportunity for Toby to make money. Toby's real passion is his blog, which he feeds with the footage from his "thirty grand BabyStrange camo coat" full of little cameras which are "embedded in the fabric" (Beukes, Moxyland 54, 276). He recklessly 'harvests' other people's reality by filming it and then selling the video footage (as a form of imaginary) to the public. Toby's role is thus twofold: He is both part of the book's hyperreality by financially profiting from the gaming missions, and is at the

109 For the description and discussion of other book covers see Joseph-Vilain, "Un Posthumain" 73-74. 
same time its co-creator by feeding the hyperreal machinery via his blog. This is what Baudrillard calls the "switch from the panoptic mechanism of surveillance $[. .$.$] to a system of deterrence in which the distinction between the pas-$ sive and the active is abolished. There is no longer any imperative of submission to the model, or the gaze 'YOU are the model!' 'YOU are the majority'" (29). Toby's coat thus not only renegotiates "[t]he old modernist dilemma of appearance and reality, of surface and depth, even of science and ideology," as Eric Smith argues (179), but it is also central to the establishment of Toby as the "arch-opportunist" (Stobie, "Dystopian Dream" 374).

The key point of Toby's opportunism is doubtlessly the game "FallenCity" (Beukes, Moxyland 147), a "realspace" (simulation) gaming mission at Adderley (Street) Station he is sent on by Unathi (146), which coincides with Tendeka's pass protests (196). The simulation game is crucial in several respects. Firstly, the episode is a spatio-temporal overlap of both Toby's gaming interests as well as his need to exploit the incident for his blog and broadcast it live for his followers' "enjoyment" (190). At the same time, the episode is an actualisation of Toby's hyperreal status. It is Toby's (mis)identification and shooting of the mission's alleged target (197-198) that sets in motion the subsequent wave of chaos, ${ }^{110}$ and, in connection with one of Toby's fellow players running amok (202) and Tendeka massacring a number of Aitos (204), ultimately leads to the release of the M7N1 virus.

Toby's mistake thus implies the (involuntary) obliteration of the boundary between game and real space as Adderley (Street) Station turns into (a) Moxyland and Moxyland becomes (a) bitter reality in turn entailing actual casualties, i.e. the Aitos, Kendra's death, the six victims of Tendeka's bombing of the immunity centre (253), and the people who fall victim to the virus, such as Tendeka. Ultimately, there is a deep irony to the fact that Toby's mission is to "[f]ind and subdue terrorists on the underway and recover and disarm [a] dirty 'suitcase' bomb" (147), which turns the game into a mise-en-abyme of the corpo-governmental counter-terrorism scheme.

It is revealing that the novel ends with Toby's opportunism. Back in his apartment, Toby uploads the video footage of Tendeka's death to his computer. When he sees Tendeka all over the news, he considers his options:

110 On aspects of panic and hysteria see also Kapstein, “Coffins" 57-58. 


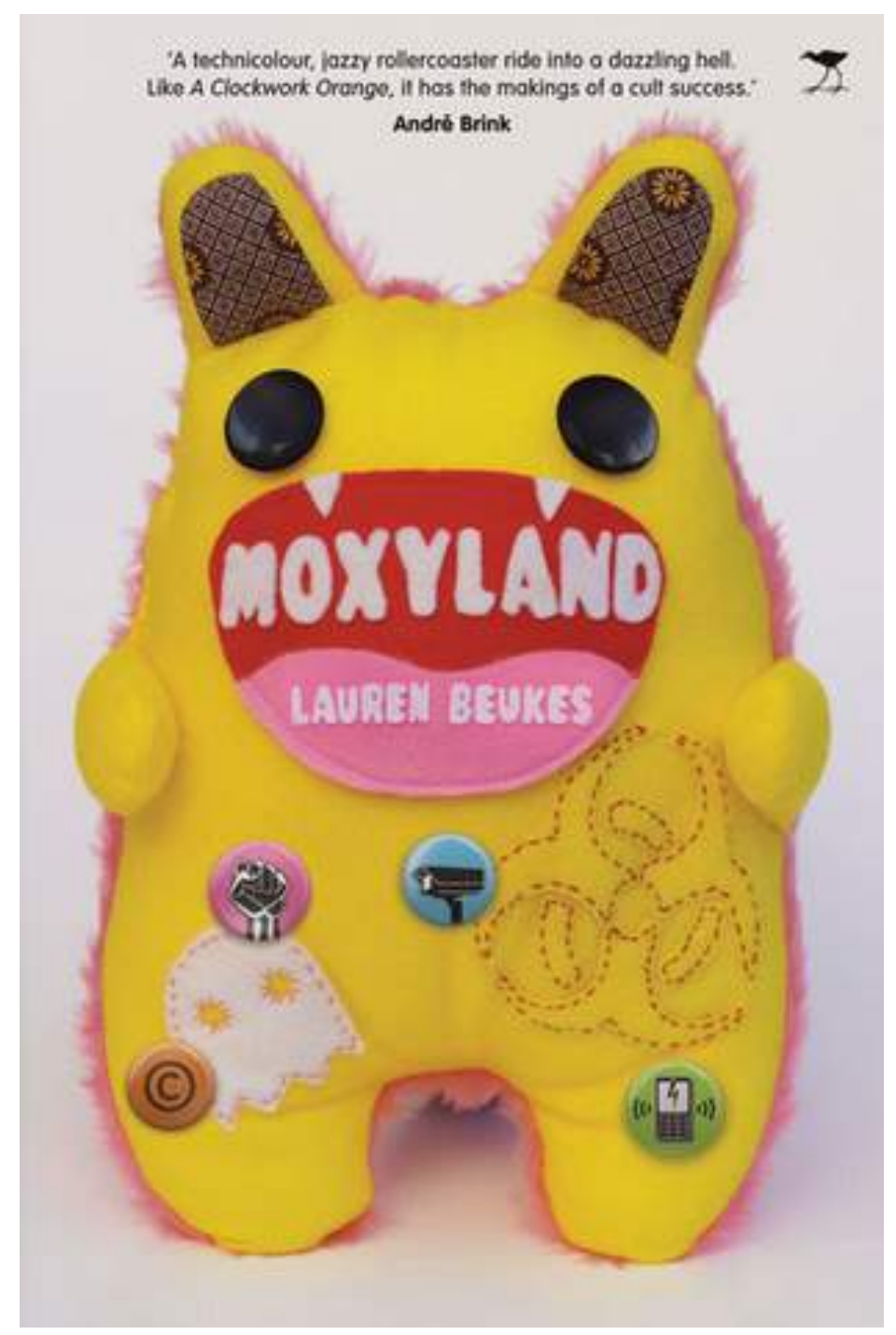

Figure 13: Cover of the First South African Edition of Moxyland by Jacana Media.

My first thought is how much shit I'm in. How I need to set fire to my entire apt and all the evidence and walk away, disappear. What flammables do I have at handy?

Or.

Or I have to total sony exclusive on the untimely and grotesque death of a terrorist.

Or a martyr. Depends on who's paying. (289)

Even though Cheryl Stobie puts Toby's option to depict Tendeka as a terrorist briefly in the balance, she suggests a more hopeful reading of the ending which, despite the prevalent scepticism, leaves the reader hoping "for Toby's better instincts to prevail", a response she ascribes as typical to the genre of critical dystopias ("Dystopian Dreams" 374). I suggest, however, that in view of the numerous examples of Toby's reckless opportunism throughout the 
novel - the hacked key card Toby uses to access his apartment block and then pockets "when Tendeka doesn't ask for it specific" (Beukes, Moxyland 275) being just one - the question of who Toby sells the footage to becomes a rhetorical one, as opportunism is Toby's strategy of survival in the most literal sense:

I stuff the coat, spare clothes and my laptop - and fuckit, the VIM, cos wherever I'm going, I'll still need a clean-up - into my bag.

I step out of the door into a whole new bright world, feeling exhausted and exhilarated.

And thirsty. (289)

The night Toby spends with Kendra thus not only neutralises the virus and leaves him immune to illnesses, but also involuntarily 'brands' him. Even though he is somewhat worn out by the events, the novel's closing lines speak to Toby's readiness to seize the next opportunity coming his way. ${ }^{111}$ With his 'branding', Toby has become even more part of the book's hyperreal world than before and, coat in bag, it appears as though he plans to continue feeding the hyperreal machinery with video footage on his blog.

\section{A 'SOUth African Watergate'}

The discussion of the four protagonists above shows that they are in fact character types that manifest themselves in different forms of involvement with the hyperreal. The prevalent corpo-governmental system and its 'ghostly' living environment thereby favour certain types over others as becomes evident in the individual outcomes of the four protagonists' plot lines. While Lerato's duplicity and Toby's opportunism turn out to be winning strategies, Kendra's naivety and Tendeka's radicalisation are deemed undesirable and ultimately lead to their deaths. Read as types, Moxyland can be imagined full of Leratos, Tobys, Kendras, and Tendekas - full of winners and losers - and it is in connection to the fictional(ised) world's topographical and topological conditions that these types of character unveil a deeper systemic critique imbedded in the novel. In order to grasp this critique, it is necessary to look briefly at the Watergate scandal and Baudrillard's reading thereof.

Watergate refers to the break-in into the offices of the Democratic National Committee (DNC), located in the Watergate office complex, on 17 June 1972 and the subsequent investigations into the involvement of then U.S. President,

111 On this point see also Kapstein, “Coffins" 56. 
Richard Nixon, and his entourage in the incident. The attempt to bug the offices of the DNC, however, was only the beginning of a series of illegal activities committed in order to secure Nixon's re-election and to cover up his involvement in the Watergate break-in. Ultimately, the investigations, which uncovered that the corruption within the White House was more ingrained than anyone had deemed possible, led to Nixon's resignation on 8 August 1974 in order to avoid impeachment. A number of Nixon's closest advisers were put on trial and sentenced with imprisonment, while Nixon himself was pardoned by his successor Gerald Ford on 8 September 1974. ${ }^{112}$

In his assessment of Watergate, Baudrillard argues:

Watergate is not a scandal, this is what must be said at all costs, because it is what everyone is busy concealing, this dissimulation masking a strengthening of morality, of a moral panic as one approaches the primitive (mise en) scène of capital: its instantaneous cruelty, its incomprehensible ferocity, its fundamental immorality [...]. (15; original emphasis)

It is thus not the Watergate break-in that is scandalous, but what Watergate suggests about the government's modus operandi more generally. Watergate, according to Baudrillard, does not expose the moral failure of the governmental system, but rather the fact that "[o]ne imputes this thinking to the contract of capital" while "it doesn't give a damn - it is a monstrous unprincipled enterprise, nothing more" (15). Neither the Watergate break-in nor its subsequent cover-up is thus scandalous. The scandal arises with the whitewashing of the government's immorality by the return to (moral) order with Nixon's resignation and Ford's inauguration.

There is, however, another twist to Baudrillard's discussion of the Watergate scandal, as he claims Watergate to be "[t]he same scenario as Disneyland (effect of the imaginary concealing that reality no more exists outside than inside the limits of the artificial perimeter): here the scandal effect hiding that there is no difference between the facts and their denunciation [...]." Watergate is not merely the beginning of a (perpetual) succession of scandals, but an illustration of society's "tending to regenerate through scandal a moral and political principle, through the imaginary, a sinking reality principle" (14). Consequently, Watergate is a source of the hyperreal, devoid of "a logic of facts and an order of reason" (16) that "allows each time for all possible inter-

112 On Watergate see e.g. Kutler; Genovese; or Olson. 
pretations, even the most contradictory - all true in the sense that their truth is to be exchanged [...] in a generalized cycle" (17).

In the light of this conceptual dissolution as suggested by Baudrillard's reading of Watergate, Moxyland's ending paints a similarly bleak and frightening picture of a hyperreal ustopian society where facts and reason are malleable and can be adapted to the sanctimonious needs of upholding social and moral order. With Kendra's and Tendeka's death as well as Lerato's imposed transfer/promotion, the chaotic turbulences of the release of the M7N1 virus come to an end and the social and moral order are (seemingly) restored. Corresponding with Baudrillard's argument, it is neither the corrupt means by which the corpo-governmental system is run nor its concealing mechanisms that are ('truly') scandalous, but the suggested prevalence and dominance of the corpo-governmental (neo-)capitalist system at the novel's end. It is in consideration of this meta-critique that Toby's sales options at the end of the novel are put into a new perspective. The question of whether he uses the video footage to good or bad avail fades given the fact that selling the footage in the first place accounts to the commodification of Tendeka's death. The system's self-induced and self-perpetuated cycle of terrorism will continue, regardless of Toby's decision, and it is the hypocrisy of this self-bread fear and the succeeding invalidation of concepts such as right and wrong, rationality and folly, or fact and fiction that lie at the heart of this meta-critique and establishes Moxyland as a 'South African Watergate'. Ultimately, the post-apartheid city is depicted as the prime site for the market-induced preservation of socioeconomic and socio-cultural extremes under the pretence of a (pseudo-)moral order that comes at the expense of the citizen's individuality.

The precession of (pseudo-)scandals and their even more scandalous cover-ups involuntarily bring post-apartheid South Africa's political arena to mind. A poignant example is the long-lasting Nkandla scandal. In accordance with Baudrillard's argument, the scandal neither lies in President Zuma's misappropriation of public funds for 'security-related' improvements to his KwaZulu-Natal homestead nor in his disregard of the report by Public Protector, Thulisile Madonsela, and its stipulated remedial actions. The 'true' scandal rather lies in President Zuma's apology to the nation in reaction to the verdict of the South African Constitutional Court on 31 March 2016 where he stated: "I wish to reiterate that any action that has been found not to be in keeping with the Constitution happened because of a different approach and different legal advice. It all happened in good faith and there was no deliberate effort or intention to subvert the Constitution on my part" (Zuma). It is in this "subtle, 
maleficent, elusive twisting of meaning" and its intended re-establishment of a (pseudo-)moral order that lies the 'veritable' scandal (Baudrillard 18).

Another salient case in point is former President Thabo Mbeki's return to the public arena and the series of comments he makes about his presidency. Mbeki's first comment, which triggered the caricature by South African cartoonist Zapiro displayed below (Figure 14), focuses on a suspected conspiracy in 2001 to remove Mbeki from office and his handling of the matter. According to Mbeki, "[ $t$ ]he Nkambule saga, which falsely implicated Phosa, Sexwale, and Ramaphosa, had nothing whatsoever to do with my alleged paranoia, which the domestic and international media has continuously trumpeted for almost fifteen years now, to date, based on false deductions and pure self-serving speculation" ("The Tragedy", par. 37). ${ }^{113}$ Mbeki has since commented on a variety of topics such as his alleged abuse of state power and his supposed AIDS denialism ("Behind the Narrative," "A Brief Commentary," and "Some Observations"). Similar to the Nkandla case described above, the scandal does not lie in Mbeki's paranoia or in his AIDS denialism but rather in his belated 'making cuts' in an attempt "to overturn 'untruths' about his presidency" (Marrian). It is by means of such acts of manipulation - which are, as Baudrillard posits, always connected to "a wavering causality in which positivity and negativity are engendered and overlap, in which there is no longer either an active or a passive" (16) - that reveals how incumbent the hyperreal is in South Africa's (everyday) political life.

\section{NARRATIVE AND SYMBOLIC HYPERREALITY}

The precession of the hyperreal as suggested by the novel's meta-critique is also reflected on a narratological, symbolic, and generic level. Reminiscent of Kendra's branding at the beginning, the surfacing of the Ghost logo on Toby's wrist at the end of the novel closes the novel's principal narrative arc.

Kendra's narrative provides another example of the novel's narrative circularity. Here is Kendra pondering the imminent nano-tech injection at the beginning of the novel: "It's nothing. An injectable. A prick. No hospital involved. Like a booster shot with added boost. Just keep telling yourself" (Beukes, Moxyland 1; my emphasis).

\footnotetext{
113 The allegations by then ANC Youth League Leader, James Nkambule, implicated Mathews Phosa (then Premier of Mpumalanga), Tokyo Sexwale (then Premier of Gauteng Province) and Cyril Ramaphosa (former MP and now President) as the masterminds of an alleged coup to oust Mbeki from office.
} 


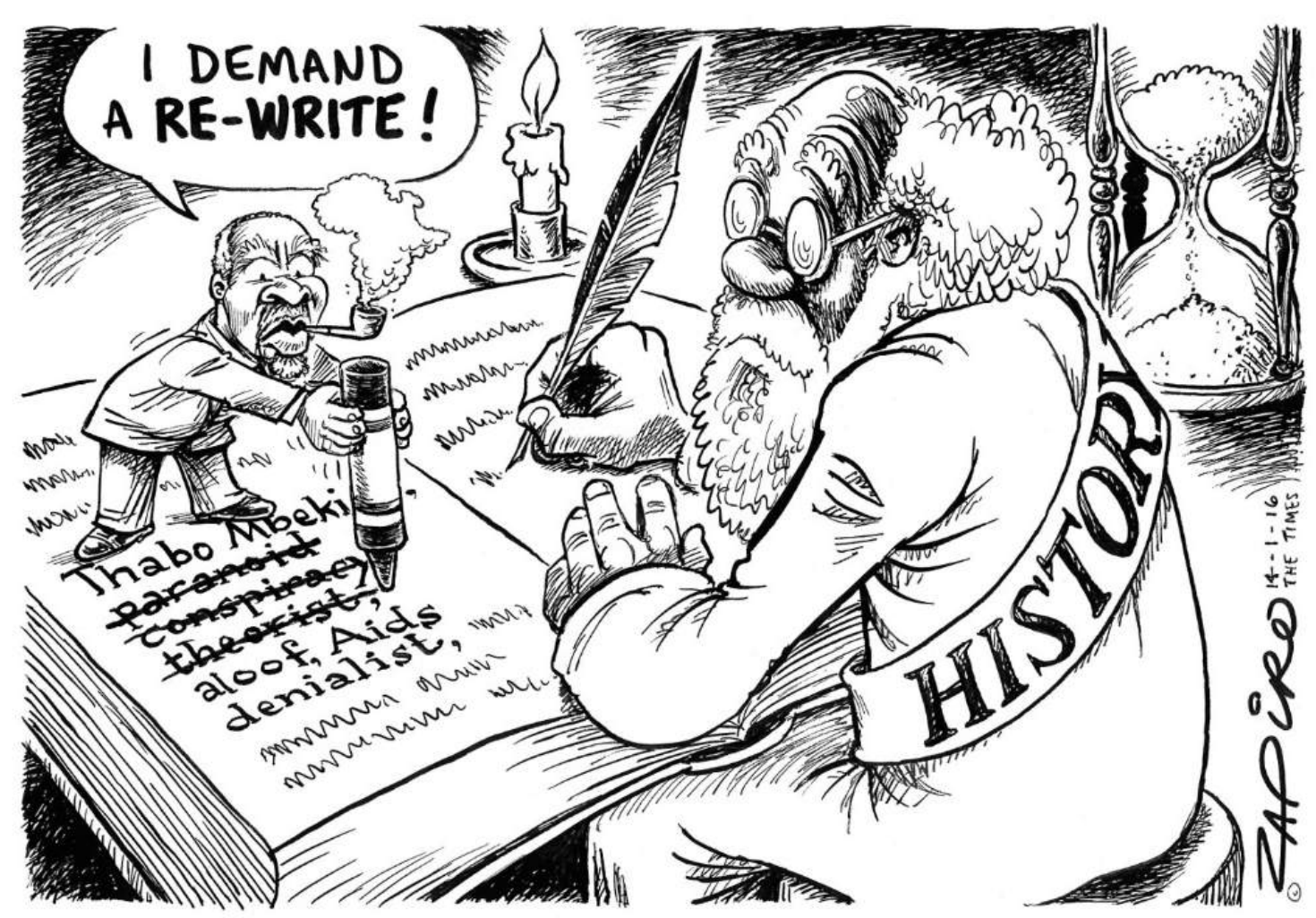

Figure 14: "Mbeki Clarifies Circumstances - 'The Tragedy of History.'” Caricature by Zapiro in The Times, 14 January 2016.

And here is the conversation between Dr Precious and Kendra right before Kendra is injected with the alleged antidote to the M7N1 virus:

'Pump your fist for me, please.'

'What happens to the dogs afterwards?'

[...]

'[...] They put the dogs down.' She sees my face. 'But don't worry, they don't feel anything. Just a prick. Then it's over.'

She positions the needle against the crook of my elbow. 'Make a fist for me.' Normally, I look away, even though I don't mind needles so much, but this time I'm watching as the slim metal head bites into my skin.

She pulls back the plunger a fraction, so that blood swirls into the chamber, like ink in water.

I look up and see that she is watching me intently.

'See,' she says, 'just a little prick.'

Still holding my gaze, she pushes the plunger all the way in. (285-286; my emphasis)

In Kendra's case, the circularity of the story line is thus linguistically undermined. The injection, which is referred to as "a prick", reappears in the con- 
versation between Dr Precious and Kendra about the Aitos' fate after their service in the police force and becomes a refrain of sorts. ${ }^{114}$ Its extended forms "just a prick" and "just a little prick" anticipate the climax, i.e. Kendra's imminent death, in a countermovement. While the refrain's increasing word count supports the growth of suspense as Kendra's plot line reaches its highpoint, the modifiers "just" and "little" have a weakening semantic function that downplays the seriousness of Kendra's situation, which she does not recognise until it is already too late, and highlights her naivety as discussed above.

Kendra's death also offers a fitting example for the symbolic reiteration of the precession of the hyperreal. She describes her last moments as follows:

The world tilts to the right, and then everything swarms up to meet me in a surge of claustrophobia. Suddenly I'm scared. I struggle up through the tightening darkness, sealing in on me, like the crush of water.

'Don't fight it.'

My eyelids flutter, letting in snatches of light like a strobe, snapshots of movement. Dr Precious pushes my shoulders, holding me down. Andile's mouth twitches. He looks away. I can't keep my eyes open. I can't move my arms. I try and push up, through the dark, which is wide open, too open, so I'm drowning in it, fighting.

Then calm.

It's just like diving.

Following the bubbles up, knowing that soon I'll break the surface. (286)

Kendra's description of her last moments before her death strongly reminds one of the comparison of her self-portrait with a night dive earlier on in the novel. It is ironic that Jonathan's teasing "about how claustrophobic, how suffocating [the night dive] would be", which Kendra argued against at the time

114 The euthanasia of the Aitos is reminiscent of J.M. Coetzee's Disgrace, where the protagonist David Lurie assists Bev Shaw, an acquaintance of his daughter Lucy, at her animal refuge with administering the lethal injections to the dogs who "suffer from distempers, from broken limbs, from infected bites, from mange, from neglect, benign or malign, from old age, from malnutrition, from intestinal parasites, but most of all from their own fertility. There are simply too many of them" (142). While the Aitos occupy a crucial position within the corpo-governmental surveillance system in Moxyland, the dogs are stripped of their guarding function in Coetzee's novel, a fact that becomes most evident in the shooting of Lucy's watchdogs by one of the young black men who invade the farm and subsequently rape Lucy (95-96). The dogs' brutal murder thereby bespeaks "the crumbling of the violent security edifice of apartheid [Lucy's] dogs exist only to uphold" (DeKoven 851). In contrast to Coetzee's Disgrace, however, the death threat waiting at the end of the Aitos' assigned purpose is extended to human beings in Moxyland. Kendra's death by lethal injection reflects the threat that the individual is exposed in the 'ghostly' corpo-governmental world once turned 'unwanted' entity. 
by describing it as "terrifying [...] but not because the darkness closed in, because it made the sea wide open" (66), resurfaces in Kendra's final account and is turned against her. In her death, Kendra's self-portrait and 'ghostly' status find their actualisation and an uncanny repetition in the most Freudian sense ("The Uncanny" 236-237).

Toby's "rotating apartment" (Beukes, Moxyland 53), which is part of a "cog system of floors, the entire building like a gyroscope in perpetual motion" (67), is another symbolic mirroring of the precession of the hyperreal. Toby's comparison of his block of flats with a "gyroscope" evokes a particularly strong image that parallels people's living conditions in the (fictional) world of Moxyland in a broader sense. A gyroscope consists of a wheel that spins around its own axis and that is surrounded by an independently rotating frame. Despite the frame's varying movements in different directions, the wheel's position and rotating axis remain unchanged. Gyroscopes are typically used for navigational purposes. They find application in navigation systems of ships, planes, or cars and have been put to use for recognition of movement in consumer electronics more recently (Oxford English Dictionary). The gyroscope's usage lends deep irony to its symbolic meaning as the novel's hyperreal world, created by the prevailing corpo-governmental system, is disorienting for the individual at best. The gyroscope's 'steady' core, as opposed to its 'altering' frame, is furthermore resonant of the individual's (social) position within the fictional world. Life for the majority of people is characterised by (social) stagnation, a rotating on the spot so to speak, while social upward movement, such as in Lerato's case, is orchestrated by the corpo-governmental system and awarded at high cost. Toby's reference to his block of flats as a "cog system" (Beukes, Moxyland 67) on the other hand, not only suggests a circular movement, which again reflects the precession of the hyperreal, but also an interlocking of the building's levels, which speaks to the interconnectedness of the various discussed manifestations of the hyperreal.

The hyperreal also finds final reiteration in the novel's narrative strategies. The novel's 'text body', as Joseph-Vilain has noted before ("Un Posthumain" 87), is of hybrid nature: The interlinking first person accounts by the four protagonists are enriched by Tendeka's police report (Beukes, Moxyland 28-31), transcriptions of online conversations between Tendeka and skyward* (e.g. 40-43), Tendeka's text messages to Toby prior to the smearing of the N2 billboard (79-80), Toby's mission briefing for the simulation game at Adderley Station (147-151), and the transcription of Toby's video commentary on Kendra (174-176). Moxyland is thus, to borrow Joseph-Vilain's concise argument, 
"a composite text that repeatedly muddles the boundary between 'reality' and 'fiction' and between different levels of textuality" ("Un Posthumain" 87; my translation). With the blurring of reality and fiction at their centre, the novel's narrative strategies themselves become concerned with the hyperreal. The constant shift between the four different narrative perspectives, which crucially contributes to the narrative's generally fast pace that is additionally 'accelerated' by means of the chapter's decreasing length towards the end of the novel, can have a dizzying effect on the (implied) reader at times. Despite the fact that the narrative perspective is anticipated by the name of the protagonist whose perspective the chapter in question is narrated from, the reader is (positively) challenged to connect the dots and is, similarly to the protagonists themselves, constantly forced to evaluate the information received in order to distinguish fact from fiction and not to lose his/her bearings. The (implied) reader is thus also caught in the precession of the hyperreal as it were, as he/she is drawn into the book's fictional(ised) world. This active involvement in the narrative brings the reader 'nearer' to the narrated events and thus parallels the protagonists' general closeness to the object of narration. This involvement is at times even directly requested from the (implied) reader, as the following extract from Toby's narrative strand shows:

'Hey man, listen, I changed my mind. I really need you to go now.'

'What the fuck? I've still got four minutes.'

'It's on the news, china. You should, wow. You need to get medical attention.'

This is not exactly a revelation, kids, although I have to tell you, I'm feeling a little more up about the whole thing, probably due to ditching that little princess Kendra. (Beukes, Moxyland 257; my emphasis)

This conversation ensues between the owner of the Internet café and Toby after the latter splits up with Kendra. Toby is trying to get in touch with Lerato to ask her for help, but is asked to leave the internet café due to his looking very sick, which connects him to the release of the M7N1 virus reported on the news. It is Toby's comment after the exchange which proves particularly interesting, as it initiates a movement along the axis of involvement with the narrative object. Toby's comment directly addresses the (implied) reader by means of the noun 'kids' and the pronoun 'you', two forms of address Toby frequently uses throughout the novel. On the one hand, this address actively promotes the (implied) reader's engagement, drawing him/her 'closer' to the object of narration. At the same time, it signifies an attempt to move away from the ob- 
ject of narration on Toby's part, as his use of the two forms of address suggests a move along the narrative near/far-axis from high involvement to medium involvement, as if Toby wanted to test and broaden the fictional world's (hyperreal) spatial expansion. The discovery of his 'branding' at the end of the novel, however, involuntarily draws him to back into the consumerist corpogovernmental system.

With Toby's and Lerato's imprisonment within the corpo-governmental system Beukes' meta-critique reaches its full capacity as it suggests a reading of South Africa's post-apartheid present through a fictional(ised) future that, similarly to Bridget McNulty's Strange Nervous Laughter, puts a group of young individuals at the centre. It is the protagonists' (re-)orientation in the thicket of the book's corpo-governmental, consumerist world that flags the system's corruption as well as its (market) cycle of self-induced and selfmaintained terrorism and fear.

However, in contrast to McNulty's novel, where Durban's tropical climate (and multicultural character) has a unifying or coupling effect (it almost serves as an interpersonal glue of sorts), the urban landscape in Moxyland puts serious restraints on (post-apartheid) subjectivities. Cape Town's fictional(ised) 'ghostly' appearance - characterised by the corporations' excessive and invasive marketing strategies, the city's denaturisation, and its unsteady weather - as well as its topography and topology of contrasts turn the city into a monstrous, hyperreal automaton in which individualism is washed out in favour of (mass) consumerism. Reminiscent of the apartheid regime's spatial policy and the growing economic disparities within post-apartheid South Africa, the city(-state) upholds a topography and topology of economic and socio-cultural extremes rather than eliminating them. Like McNulty's novel, Moxyland can thus be said to be ustopian in character. In contrast to Strange Nervous Laughter, however, the novel's distinctly hyperreal character gives decidedly more emphasis to the dystopian than the utopian. 


\section{CONCLUSION}

Apartheid was, at its core, distinctly spatial. Its numerous rules and regulations aimed to separate South Africa's white population from its non-white counterpart. Essentially, apartheid was the history of a white minority's rule over a non-white majority according to the former group's ideal of a racially separated cohabitation and the policing of the country's land and non-white inhabitants to the sole advantage of the white minority. This segregationist tenet of the apartheid system was, according to Vivian Bickford-Smith and his colleagues, accommodated under the cloak of early twentieth-century modernist town planning as "[b]oth were concerned with zoning, with placing people in appropriate space, moving them from inappropriate localities" (144). The South African city was, as I have shown in the Introduction, a particularly contested space. Even though the non-white population was crucial to the economic functioning of the South African city, the apartheid system aimed at excluding that population group from the city, reducing it to a mere labour force. This effectively ascribed a 'ghostly presence' to the country's non-white population within the South African city. First attempts at racial segregation date back to the mid-nineteenth century, with these attempts, in turn, finding their roots in colonial thinking and colonial history more generally. Consequently, space and place meant decidedly different things to different people at different times throughout South Africa's past and, considering their persistent importance throughout the country's spatially fraught history, the extent to which they are of continuing significance in the post-apartheid present is not surprising.

It is in light of the spatial determinedness of both the apartheid system in particular and South Africa's history more generally, that I have suggested a decidedly spatial approach to my analysis of six post-apartheid novels, focussing on the interrelatedness, or rather entanglement, of shifting post-apartheid subjectivities and urban space (and place). The starting point for the theoretical framework of my study was Sarah Nuttall's and Achille Mbembe's 'reading' of Johannesburg. Based on Mbembe's postcolonial theory, Nuttall and Mbembe seek to break away from the negative perception of the (South) African city as 'the Other' by taking into account Johannesburg's socio-historical context and complexity, which they see inextricably linked to the city's spatiality and topography. Their decoding of Johannesburg along horizontal and vertical axes accounts for the division of the city according to socio-economic cri- 
teria and considers various lines of division such as language, class, or the city's separation into a surface and below on the basis of its mining history. Such a spatial dialectics, which reads the horizontal and the vertical in connection to each other, is a powerful analytical tool that accounts for Johannesburg's socio-historical complexity by employing a diversity of considerations and increased contextual nuance which, as I have argued and shown with my discussion of the six selected post-apartheid novels set in Durban and Cape Town, is applicable beyond the city of Johannesburg.

The second key concept of my theoretical framework was Sarah Nuttall's concept of entanglement - a state of multiple overlaps and/or intersections, of being bundled and/or knotted - as a continuation of, and addition to, Nuttall's and Mbembe's joint endeavours. Nuttall suggests different forms of entanglements as proposed by several other scholars and uses the metaphor as a tool to decode the socio-cultural and socio-economic realities of post-apartheid South Africa in their full complexity. Entanglement becomes an entry point to under- and misrepresented cultural archives such as the literary city and the literary texts' representation of various city-spaces and city-dwellers.

While Nuttall's and Mbembe's reading of Johannesburg is of a primarily topographical nature, i.e. it emphasises the importance of the city's morphology and spatial expansion as emerged from the place's socio-historical and economic conditions, Nuttall's concept of entanglement is of a predominantly topological character, i.e. it underlines structural elements of spatial relations and their complexity as prevalent in the post-apartheid context. In order to combine the two approaches, which essentially work under inverse auspices, I have then suggested consolidating Nuttall's and Mbembe's primarily topographical and Nuttall's essentially topological approach under an overarching theory of space and place based on Doreen Massey's theory of space-time. Massey conceives of space (and place) as: (1) resulting from social relations, (2) being characterised by multiple, coexisting social relations, (3) always being under construction and thus constantly changing and/or adapting. Massey's theoretical approach was particularly suitable as she understands space and time as inextricably linked, which opened lines of inquiry in my own analysis which may have otherwise been closed.

Firstly, Massey's dynamic conception of space allowed me to draw temporal aspects into the analysis as a more constant thread than offered by Nuttall's and Mbembe's analytical metaphors at first glance. Secondly, Massey's notion of space made it possible to account more consistently for the decidedly political nature of space, by means of Massey's concept of power-geometries 
which refers to distinct ways in which particular (spatial) relationships are constituted with regard to certain aspects such as people's mobility within, or influence on, these particular relationships. Even though Nuttall, for example, includes politics into her concept of entanglement by means of the notion of creolisation, which, for her, denotes the violent and unequal character of sociocultural and socio-economic entanglements as well as their (positive and negative) implications, the importance of prevalent power-geometries and their effect on individuals are side-lined, particularly in her analysis of the literary city.

With these multiple, interrelated theoretical concepts in mind - themselves already an intricate entanglement - I analysed the relation between shifting post-apartheid subjectivities and urban space (and place) in a selection of six post-apartheid texts. Each of my three analysis chapters compared and contrasted two literary texts, one set in Durban and the other in Cape Town. Each chapter had a particular spatio-temporal focus: Chapter 1 focused on aspects of nostalgia, Chapter 2 on notions of madness, and Chapter 3 on aspects of the uncanny and the hyperreal as distinctly ustopian manifestations. The structure of my study thus followed a particular spatio-temporal ordering that was informed by a progression from the past to the present and the future in its broadest sense, all three temporalities, however, always overlapping and interrelating, thus immediately breaking up the seemingly chronological ordering. The nostalgic focus of Chapter 1 looked back on the (apartheid) past and was interested in the past's effect on the present (and the potential future) as portrayed in Mariam Akabor's Flat 9 and Rozena Maart's Rosa's District Six. Chapter 2, in turn, was concerned with a particular (past) present - a snapshot of the late 1990s and last turn of the millennium - which is perceived as a mad or maddening space-time in Johan van Wyk's Man Bitch and K. Sello Duiker's Thirteen Cents. Chapter 3, finally, focused on fictional(ised) future space-times, as I read Bridget McNulty's Strange Nervous Laughter and Lauren Beukes' Moxyland as two ustopian projections of potential post-apartheid futures of uncanny/unhomely and hyperreal proportions, respectively.

My study's structure is thus in line with the general fluidity of the theoretical concepts on which I base my analyses, as they account for the multilayered and disrupted complexity of socio-historical and -economic conditions and developments. Each of my three focuses thereby shed the light of a different perspective onto the fictional(ised) post-apartheid realities as represented in the different literary texts, thus uncovering differing layers in the constitu- 
tion of various shifting post-apartheid subjectivities and their interrelation with space (and place).

Overall, the fictional(ised) depiction of Durban and Cape Town in the selection of post-apartheid texts I have chosen for my study is versatile. Considering the limited sample of six texts, however, any of the following conclusions made with regard to repetitive patterns in the representation of postapartheid space-time, post-apartheid subjectivities, and their entanglements are necessarily restricted. Further research may tell to what extent other texts exhibit similar tendencies in their depiction of post-apartheid Durban and Cape Town as well as post-apartheid Durbanite and Capetonian subjectivities, or to what extent they broaden the representational repertoire of postapartheid space-time.

The texts I analysed, however, repeatedly put to use the weather to reflect the 'subjectivity' of post-apartheid Durban and Cape Town. Such an atmospheric condensation taps into an age-old literary principle that bespeaks the human vision of an ancient bond between the subject and the cosmos, such as is the case in Shakespeare's King Lear or The Tempest, for example, where the stormy weather reflects both King Lear's and Prospero's psychological state as well as the tumultuous power-geometries at play. While Cape Town is characterised by its windy, cloudy, and/or rainy weather conditions in all three Cape Town-based texts, Durban's (sub)tropical climate is central to Strange Nervous Laughter, where it functions as a socio-cultural glue, and is also repeatedly mentioned in Flat 9. Cape Town's inclement weather, in contrast, anticipates and corroborates the fictional(ised) post-apartheid city's depiction as an economic behemoth, particularly in Moxyland and its corpo-governmental world but also in Thirteen Cents and Azure's entanglement in the city's economy of crime and prostitution. The latter is also pivotal in Man Bitch, which draws a similarly sinister picture of Durban in reflection of the white protagonist's increasing unease within South Africa's new dispensation. Together with Thirteen Cents and Strange Nervous Laughter, considering the ending of the latter text, one may go so far as to say that Man Bitch paints the post-apartheid city as an apocalyptic or hellish place. While the protagonist's apocalyptic perception of the city mirrors his uncomfortable subject position and the catch-22 situation, the apocalypse has a more positive function in Thirteen Cents and Strange Nervous Laughter. The apocalyptic destruction at the end of Thirteen Cents, for example, offers Azure the much-needed 'clean slate' to re-assert his black subjectivity and start anew. The fire at the end of Strange Nervous Laughter can be seen as performing a similarly liberating function. 
The portrayal of fictional(ised) subjectivities, for both Durban and Cape Town, is thus still marked by apartheid and its legacy. This 'spatio-temporal markedness' can take many forms, such as an older Indian South African generation's apartheid nostalgia, which results in high hopes for, and great expectations of, a younger generation and, as a result, the latter's restricted ability to determine their lives, such as it is portrayed in Akabor's Flat 9. In Beukes' Moxyland, in contrast, this 'spatio-temporal markedness' is reflected in the techno-consumerist determination which reduces subjectivities to types and predicates their survival on the usefulness for the neo-liberal post-apartheid city(-state). At the same time, it is conspicuous to what extent the fictional(ised) subjectivities are portrayed as still being 'racially marked'. A case in point here is van Wyk's Man Bitch. Despite the protagonist's initial nonracialist intention behind his relocation to Durban's Point area and his interracial relationships with different prostitutes, his actions throughout the novella unearth deeply rooted racial preconceptions that re-establish rather than overcome racial boundaries. In McNulty's Strange Nervous Laughter, which is similarly invested in a non-racialist agenda, the interracial relationships break apart or are removed from South Africa's new dispensation where they do not seem to 'find their place', while the mono-racial relationships survive.

Ultimately, the prevailing 'racial markedness' of the fictional(ised) subjectivities, together with their continuing 'spatio-temporal markedness', speaks to the ongoing effect and importance of what Derek Hook, based on Freud, calls "apartheid nachträglichkeit" (186; original emphasis), which I discussed in more detail in Chapter 1 in connection to the younger South African Indian generation's difficulty to determine their lives due to their (grand)parents' apartheid nostalgia in Flat 9 and the resurfacing of the forced removals from District Six in Rosa's District Six. The continuing infringement of the apartheid past on the post-apartheid present also reveals how fraught "the psychosociality of the (post)apartheid period", i.e. the interrelation and co-constructedness of a person's inner and outer reality or his/her psyche and social surroundings, still is (Hook 8). This becomes particularly evident in view of the 2015 (and 2016) student protests which I mentioned in Chapters 2 and 3. The protests initiated a transformation debate that was triggered by the demand to have the Cecil John Rhodes statue, which was seen as a symbol of white supremacy, removed from UCT's upper campus and the call for the name of Rhodes University to be changed in April 2015. The protestors took issue with the difficulties for poor (and thus mainly black) South Africans to access institutions of higher education. The protests have since evolved to an all- 
encompassing call to decolonise South Africa's racially disparate university system. The infamous comparison of black beachgoers to 'littering monkeys' by the KwaZulu-Natal real estate agent Penny Sparrow in January 2016 and the racial debate that it has (re-)kindled is another case in point (Mutiga; Pilane; Wicks).

Considering that the texts I analysed in my study predate these events by (roughly) a decade or more, it can be said that they not only anticipate the present socio-political developments in South Africa, but they also speak to the prolonged dormancy of racial and spatio-temporal issues in post-apartheid South Africa and their psychosocial effects. The texts' fictional(ised) depiction of various socio-cultural and socio-economic tensions - in hindsight, as snapshots of a particular space-time, but most importantly (far) ahead of their time - is thus testimony to a literary text's ability to re-visit, capture, as well as project the zeitgeist of a particular space-time in all of its multiplicity and complexity and buttresses the creative contribution of literature as a form of 'thick description' (Geertz), thus nominating literary studies as an important counterweight to (more) quantitatively oriented studies of other academic fields such as economy, sociology, history, or anthropology, as I argued in Introduction.

While I have discussed a selection of texts published within a rather short timeframe - Thirteen Cents, the oldest text, was published in 2000 and Moxyland, the most recent text I discussed, in 2008 - the South African literary scene, as I pointed out in the Introduction, has been thriving since the last turn of the millennium and has seen many exciting new authors emerge. Further research in the interrelatedness of shifting post-apartheid subjectivities and space(-time) would doubtlessly profit from an analysis of further, more recent texts as well as a quantitatively larger selection of texts, and a broadening of my geographically restricted focus on just two of South Africa's cities. Of these, the study of a quantitatively larger sample of more recent texts, thus offering what Franco Moretti famously labelled a 'distant reading', would prove particularly fruitful to further our understanding of the literary repertoire put to use in representations of the post-apartheid city. In his seminal essay "Conjectures of World Literature", Moretti defines (world) literature as a problem, rather than an object, in search of new methodological approaches to reading literary texts (46). 'Distant reading', Moretti's suggested solution to the problem, means the analysis of a great number of texts in search of shared "devices, themes, tropes - or genres and systems" (49).

Margaret Lenta's discussion of a variety of debut novels by a young(er) generation of South African authors is an example of such a distant reading in 
Moretti's sense of the term. As I showed in the Introduction, Lenta suggests the focus on 'previously silenced communities', 'sex and gender', the 'mixture of language', aspects of 'writing back' to earlier South African works of literature, the 'roman à thèse', and the element of 'fusion' to be recurring themes in South African literature after 2000 (53). I would argue that nostalgia (and related questions of (im)memorability), madness, and ustopias - the three focuses I have suggested for the analysis of my selection of texts - could be added to Lenta's list. In what follows, I would like to suggest some possible texts that could be considered.

An example of a recent novel concerned with aspects of nostalgia is Carol Ann Davids' The Blacks of Cape Town. The novel follows the historian Zara Black who lives in self-exile in the United States. Far from home, she is confronted with her family's past in and beyond District Six when receiving a letter from the government that threatens to publicly denounce her father as a traitor of the anti-apartheid movement. Spurred by the allegations into uncovering the truth, Zara starts to research her family history. Flooded by nostalgic memories - some of them fond, others troubling, yet others merely imagined in the process, she is constantly forced to re-imagine District Six, its inhabitants, and her father's role in the anti-apartheid struggle. Similar to Maart's Rosa's District Six, the nostalgia at play in The Blacks of Cape Town displays elements of (un)reliability and, in light of her grandfather's 'passing' as white and her father's questionable role in the anti-apartheid struggle, is linked to aspects of pretence and lies. Particularly Zara's tendency to imagine encounters between particular characters and whole conversations add another facet of (im)memorability to the notion of nostalgia that reflects 'clouding' as a mechanism in fending off and refusing to allow undesirable and unpleasant memories and facts to resurface. Another recent text that engages nostalgically with District Six is Nadia Davids' An Imperfect Blessing.

Niq Mhlongo's Way Back Home is a recent novel that treats aspects of madness. Mhlongo's novel tells the story of Kimathi Tito, a former soldier of the ANC's armed liberation struggle, Umkhonto we Sizwe (MK). During service at a camp in Angola, Kimathi falls in love with Senami, one of his female comrades, whom he tortures, rapes, and kills as Kimathi cannot accept Senami's rejection of his sexual advances. Returning to South Africa after the demise of apartheid, Kimathi comes to great riches as a corrupt businessman. Kimathi's past, however, catches up with him as Senami's ghost haunts him. He suffers from PTSD as well as a bipolar affective disorder and is increasingly burdened by his role in MK in the form of recurring nightmares. As a last 
attempt to atone for his sins, Kimathi travels to Angola with Senami's parents to recover Senami's body and put her soul to rest by burying her 'back home' in South Africa. During the journey to Angola, the two narrative strands alternate with ever-growing 'speed', as the chapters become shorter and shorter, merging once Kimathi and Senami's parents arrive in Angola. What starts as a space-time overlap ends in a space-time collapse that reflects Kimathi's deteriorating mental health and his growing unease, ultimately leading to his suicide at the end of the novel. Further possible texts for this theme would be Zainub Priya Dala's What About Meera, K. Sello Duiker's The Quiet Violence of Dreams, Patricia Schonstein Pinnock's Skyline, or Perfect Hlongwane's Jozi.

Charlie Human's Apocalypse Now Now and Kill Baxter, finally, are examples of recent ustopian texts. Apocalypse Now Now follows the teenage boy Baxter Zevcenko who, in pursuit of his missing girlfriend, is introduced to Cape Town's magical underworld where he is confronted with his mixed, magical heritage. It is, similar to Duiker's Thirteen Cents, the apocalyptic destruction of an alternate-reality Cape Town that leads to Baxter's acknowledgement of his mixed magical heritage. In Kill Baxter, Baxter's adventures continue as he is recruited to Hexpoort, a school of magic that is threatened by destruction. As I have argued elsewhere, together with Alan Muller, Baxter's personal journey is tied "to the larger issue of South African whites having to (re-)locate themselves within the country's new dispensation, a process, as the novels' contemporaneity suggest, that is still ongoing" in post-apartheid Sout Africa and further research into the flourishing genre of speculative fiction would add to the discussion of the genre's "non-realist potential [...] to create worlds where spaces, histories, and mythologies that were thought of as separate are (re-)considered and (re-)written in a way that entangles them in a world where they must work together in order to reach their full [...] potential" (94). Alternatively, further research into the genre could consider ways in which speculative fiction might disavow and/or write against the utopian aim of a nonracial post-apartheid future. Other possible ustopian texts that could be considered are Angela Meadon's A Taste of You, a Durban-set zombie novel, Paul Crilley's Poison City, a Durban-based supernatural crime novel, or Lily Herne's Cape Town-based, post-apocalyptic Mall Rats series.

Nevertheless, by offering a close reading of a selection of six recent postapartheid texts, I have discussed the fictional(ised) socio-cultural and -economic realities in their multi-layered complexity from a variety of vantage points as represented in my chosen texts. In doing so, this study has foregrounded the importance of the entanglement between shifting post-apartheid 
subjectivities and space (and place), highlighting notions of nostalgia, madness, and ustopia. 


\section{WORKS CITED}

Abdool Karim, Salim S., and Quarraisha Abdool Karim, editors. HIV/AIDS in South Africa. 2nd ed., Cambridge University Press, 2010.

"About Linden Lab." Linden Lab, n.d., www.lindenlab.com/about. Accessed 14 Aug. 2015.

Abrahams, Peter. The Path of Thunder. 1948. David Philip Publishers, 1984. . Mine Boy. Faber \& Faber, 1946.

Abrams, Meyer H. A Glossary of Literary Terms. $8^{\text {th }}$ ed., Thomson Wadsworth, 2005.

A Dictionary of South African English on Historical Principles. $4^{\text {th }}$ ed., edited by Silvia Penny et al., Oxford University Press, 1991.

Akabor, Mariam. Personal Interview. 5 March 2015.

. “The Muezzin's Daughter." Unpublished MA thesis, University of KwaZulu-Natal, 2009.

. Flat 9. umSinsi Press, 2006.

Akpome, Aghogho. "Towards a Reconceptualization of '(Post)Transitional' South African Cultural Expression." English in Africa, vol. 43, no. 2, 2016, pp. 39-62.

American Psychiatric Association. Diagnostic and Statistical Manual of Mental Disorders. $5^{\text {th }}$ ed., American Psychiatric Publishing, 2013.

"Anti-Indian Legislation 1800s-1959." South African History Online, 20 March 2011， www.sahistory.org.za/article/anti-indian-legislation-1800s-1959. Accessed 20 Aug. 2017.

"Apartheid Legislation 1850s-1970s." South African History Online, 20 March

2011, www.sahistory.org.za/article/apartheid-legislation-1850s-1970s.

Accessed 20 Aug. 2017.

Appadurai, Arjun, and Carol A. Breckenridge. "The Risk of Johannesburg." Afterword. Nuttall and Mbembe, pp. 351-354.

Appiah, Kwame A. "'Spiritual Realism.'” The Nation, vol. 255, no. 4, 1992, pp. 146-148.

Appollis, Basil. "My Word! Redesigning Buckingham Palace." Unpublished Play, Cape Town, 2013.

Atwood, Margaret. In Other Worlds: SF and the Human Imagination. Doubleday, 2011.

Au, Wagner J. The Making of Second Life: Notes from the New World. Collins, 2008. 
Bachmann-Medick, Doris. Cultural Turns: Neuorientierung in den Kulturwissenschaften. Rowohlt Taschenbuch Verlag, 2006.

Bamford, Helen. "New Plan for Cape Town's Unfinished Bridge." IOL, 10 June 2016, www.iol.co.za/motoring/industry-news/new-plan-for-cape-towns -unfinished-bridge-2032952. Accessed 26 July 2017.

Bank, Andrew, and Gary Minkley. "Genealogies of Space and Identity in Cape Town." Editorial. Kronos: Journal of Cape History, vol. 25, no. 1, 1998/1999, pp. 4-16.

Baudrillard, Jean. Simulacra and Simulation. 1981. Translated by Sheila Faria Glaser, University of Michigan Press, 1994.

Benjamin, Walter. Charles Baudelaire: A Lyric Poet in the Era of High Capitalism. Translated by Harry Zohn, Verso, 1983.

. The Arcades Project. 1982. Translated by Howard Eiland and Kevin McLaughlin, The Belknap Press of Harvard University Press, 1999.

Bethlehem, Louise. "Lauren Beukes' Post-Apartheid Dystopia: Inhabiting Moxyland." Journal of Postcolonial Writing, vol. 50, no. 5, 2014, pp. 522-534.

Beukes, Lauren. Slipping: Stories, Essays \& Other Texts. Tachyon Publications, 2016.

. Personal Interview. 30 March 2015.

. Broken Monsters. Umuzi, 2014.

. The Shining Girls. Umuzi, 2013.

. Zoo City. Jacana Media, 2010.

. Moxyland. Jacana Media, 2008.

. Maverick: Extraordinary Women from South Africa's Past. Oshun Books, 2005.

Bhabha, Homi K. The Location of Culture. Routledge, 1994.

Bickford-Smith, Vivian. The Emergence of the South African Metropolis: Cities and Identities in the Twentieth Century. Cambridge University Press, 2016.

- "Creating a City of the Tourist Imagination: The Case of Cape Town, 'The Fairest Cape of Them All.'” Urban Studies, vol. 46, no. 9, 2009, pp. 1763-1785.

. Ethnic Pride and Racial Prejudice in Victorian Cape Town: Group Identity and Social Practice, 1875-1902. Cambridge University Press, 1995.

. "The Origins and Early History of District Six to 1910." Jeppie and Soudien, pp. 35-43.

Bickford-Smith, Vivian, et al. Cape Town in the Twentieth Century: An Illustrated Social History. David Philip Publishers, 1999. 
de Boeck, Filip, and Marie-Françoise Plissart. Kinshasa: Tales of the Invisible City. Ludion, 2004.

Borsò, Vittoria. "Topologie als literaturwissenschaftliche Methode: Die Schrift des Raums und der Raum der Schrift." Günzel, Topologie, pp. 279-295.

Boym, Svetlana. The Future of Nostalgia. Basic Books, 2001.

Bremner, Lindsay. "Reinventing the Johannesburg Inner City." Cities, vol. 17, no. 3, 2000, pp. 185-193.

Breytenbach, Cloete, and Brian Barrow. The Spirit of District Six. 1970. Human \& Rousseau, 1997.

“Bridget McNulty.” KZN Literary Tourism, n.d., www.literarytourism.co.za/ index.php?option $=$ com_content\&view $=$ article\&id $=157$ :bridgetmcnulty\&catid=13:authors\&Itemid=28. Accessed 1 Nov. 2014.

"Bridget McNulty: Profile." Contently, 2014. www.bridgetmcnulty. contently.com. Accessed 1 Nov. 2014.

Brink, André P. The Rights of Desire. 2000. Random House, 2001.

“'Broken Monsters' Acquired by Endemol's Additional Dialogue for Drama Series." Deadline, 2015. www.deadline.com/2015/01/broken-monsterstv-series-endemol-additional-dialogue-1201355261/. Accessed 22 Jan. 2015.

Browett, John. "The Evolution of Unequal Development within South Africa: An Overview." David M. Smith, Living Under Apartheid, pp. 10-23.

Buikema, Rosemarie. "The Arena of Imaginings: Sarah Bartmann and the Ethics of Representation." Doing Gender in Media, Art and Culture, edited by Rosemarie Buikema and Iris van der Tuin, Routledge, 2007, pp. 70-85.

Bundy, Colin. Short-changed? South Africa since Apartheid (Jacana Pocket Guide). Jacana Media, 2014.

Butler, Judith. Gender Trouble. 1990. Routledge, 2007.

Bystrom, Kerry. Democracy at Home in South Africa: Family Fictions and Transitional Culture. Palgrave Macmillan, 2016.

Calvino, Italo. Invisible Cities. 1972. Translated by William Weaver, Hardcourt Brace \& Company, 1974.

Carolin, Andy, and Ronit Frenkel. "Sex in the Text: Representations of SameSex Intimacies in K. Sello Duiker's The Quiet Violence of Dreams." English Studies in Africa, vol. 56, no. 2, 2013, pp. 36-48.

de Certeau, Michel. The Practice of Everyday Life. 1980. Translated by Steven Rendall, University of California Press, 1984.

Chapman, Michael. Preface. Chapman and Lenta, pp. vii-viii. . "SA Lit beyond 2000?" Introduction. Chapman and Lenta, pp. 1-18. 
. "Conjectures on South African Literature." Introduction. Beyond 2000:

South African Literature Today, special issue of Current Writing: Text and

Reception in Southern Africa, vol. 21, no. 1-2, 2009, pp. 1-23.

Chapman, Michael, and Margaret Lenta, editors. SA Lit Beyond 2000. University of KwaZulu-Natal Press, 2011.

Carnie, Tony. "New-Look Durban Point Plans Revealed." IOL, 12 July 2013, www.iol.co.za/news/south-africa/kwazulu-natal/new-look-durbanpoint-plans-revealed-1545897. Accessed 30 Nov. 2015.

City of Cape Town. Integrated Annual Report 2015/2016, www.capetown.gov.za /local\%20and\%20communities/meet-the-city/city-reports/annualreports. Accessed 20 Aug. 2017.

Clark, Nancy L., and William H. Worger. South Africa: The Rise and Fall of Apartheid (Seminar Studies in History). 2nd ed., Longman, 2011.

Coetzee, John M. Disgrace. Secker \& Warburg, 1999. . White Writing: On the Culture of Letters in South Africa. Yale University Press, 1988.

Conrad, Joseph. Heart of Darkness. 1899. Classics Edition, 2015.

Cooper, Brenda. Magical Realism in West African Fiction: Seeing with a Third Eye. Routledge, 1998.

Coovadia, Imraan. Tales of the Metric System. Umuzi, 2014.

. High Low In-Between. Umuzi, 2009.

. Green-Eyed Thieves. Umuzi, 2006.

. The Wedding. Picador, 2001.

Coverly, Merlin. The Art of Wandering: The Writer as a Walker. Oldcastle Books, 2012.

. Psychogeography. Pocket Essentials, 2010.

Crilley, Paul. Poison City. Hodder \& Stoughton, 2016.

Dala, Zainub Priya. What About Meera. Umuzi, 2015.

Dangarembga, Tsitsi. Nervous Conditions. 1988. Ayeba Clarke Publishing, 2004.

Dangor, Achmat. Bitter Fruit. Kwela Books, 2001.

. Waiting for Leila. Raven Books, 1981.

Dardagan, Colleen. "Interest in Point Precinct Piqued." The Mercury, 4 Nov. 2015, p. 1.

Davids, Carol Ann. The Blacks of Cape Town. Modjaji Books, 2013.

Davids, Nadia. An Imperfect Blessing. Umuzi, 2014.

Davis, Geoffrey V. "'An Island of Apartheid': Richard Rive's District Six." Voices of Justice and Reason: Apartheid and Beyond in South African Literature, edited by Geoffrey V. Davis, Editions Rodopi B.V., 2003, pp. 87-108. 
Dear Grandfather, Your Right Foot Is Missing. Directed by Yunus Ahmed. Ahmed Productions, 1984.

DeKoven, Marianne. "Going to the Dogs in Disgrace." ELH, vol. 76, no. 4, 2009, pp. 847-875.

Delport, Peggy. "Signposts for Retrieval: A Visual Framework for Enabling Memory of Place and Time." Rassool and Prosalendis, pp. 31-46.

Demir, Danyela. Reading Loss: Post-Apartheid Melancholia in Contemporary South African Novels. Logos Verlag, 2019.

Demir, Danyela, et al. "In Search of a 'Rock Star': Commemorating Kabelo Sello Duiker's Life and Work Ten Years on." Current Writing: Text and Reception in Southern Africa, vol. 27, no. 1, 2015, pp. 26-37.

Derrida, Jacques. Of Hospitality. Translated by Rachel Bowlby, Stanford University Press, 2000.

. "Cogito and the History of Madness." Writing and Difference. 1967. Translated by Alan Bass, Routledge Classics, 2001, pp. 36-76.

Desai, Ashwin, and Goolam Vahed. Inside Indenture: A South African Story 1860-1914. HSRC Press, 2010.

Dewar, Neil. "'Stemming the Tide': Revitalizing the Central Business District of Cape Town." South African Geographical Journal, vol. 86, no. 2, 2004, pp. 91-103.

Diala-Ogamba, Blessing. "Rhetorics of Violence in Alex La Guma's Novels." African Rennaissance, vol. 2, no. 6, 2005, pp. 136-145.

District Six Museum. District Six Museum, n.d., www.districtsix.co.za. Accessed 02 Dec. 2015.

District 9. Directed by Neill Blomkamp. TriStar Pictures, 2009.

Dlamini, Jacob. Native Nostalgia. Jacana Media, 2009.

Duiker, K. Sello. The Hidden Star. Umuzi, 2006.

. “The Last Word': Sello Duiker." Mzamane, pp. 27-30.

. "Interview with Victor Lackay." Mzamane, pp. 19-21.

. "The Streets and the Gods of Truth." Rhodes Journalism Review, vol. 24, 2004, pp. 8-9.

. Thirteen Cents. 2000. Ink Inc., 2002.

. The Quiet Violence of Dreams. Kwela Books, 2001.

Duncan, Rebecca. "Contemporary South African Horror: On Meat, NeoLiberalism and the Postcolonial Politics of a Global Form." Horror Studies, vol. 5, no. 1, 2014, pp. 85-106.

Durrheim, Kevin, and John Dixon. Racial Encounter: The Social Psychology of Contact and Desegregation. Routledge, 2005. 
Earnest, Amelia. “On Cape Town's Road to Nowhere.” Daily Maverick, 31 July 2013, www.dailymaverick.co.za/article/2013-07-31-on-cape-towns-roadto-nowhere/. Accessed 25 July 2017.

Eco, Umberto. Faith in Fakes: Travels in Hyperreality. 1983. Translated by William Weaver, Vintage, 1998.

van Eeden, Janet. "Best Reads 2007: Janet van Eeden." News 24, 28 Nov. 2007, www.news24.com/Archives/Witness/Best-reads-2007-Janet-van-Eeden20150430. Accessed 1 Nov. 2014.

Enzensberger, Hans Magnus. "The Terrorist Mindset: The Radical Loser." Translated by Nicholas Grindell. Spiegel Online, 20 Dec. 2006, www.spiegel.de/international/spiegel/the-terrorist-mindset-the-radicalloser-a-451379.html. Accessed 11 Aug. 2015.

Erasmus, Zimitri. "Apartheid Race Categories: Daring to Question their Continued Use." Transformation: Critical Perspectives on South Africa, no. 79, 2012, pp. 1-11.

. "Re-imagining Coloured Identities in Post-Apartheid South Africa." Introduction. Coloured by History, Shaped by Place: New Perspectives on Coloured Identities in Cape Town (Social Identities South Africa Series), edited by Zimitri Erasmus, Kwela Books, 2001, pp. 13-28.

Erll, Astrid. "From 'District 6' to District 9 and Back: The Plurimedial Production of Travelling Schemata." Transnational Memory: Circulation, Articulation, Scales, edited by Chiara De Cesari and Ann Rigney, de Gruyter, 2014, pp. 29-50.

Fanon, Frantz. The Wretched of the Earth. 1961. Translated by Richard Philcox, Grove Press, 2004.

. Black Skin, White Masks. 1952. Translated by Richard Philcox, Grove Press, 2008.

Farred, Grant. Midfielder's Moment: Coloured Literature and Culture in Contemporary South Africa. Westview Press, 2000.

Feder, Lillian. Madness in Literature. Princeton University Press, 1980.

Felman, Shoshana. Writing Madness: (Literature/Philosophy/Psychoanalysis). Translated by Noel Evans et al., Stanford University Press, 1985.

Field, Roger. Alex La Guma: A Literary and Political Biography. Jacana Media, 2010.

Fortune, Linda. The House in Tyne Street: Childhood Memories of District Six. Kwela Books, 1996.

Foucault, Michel. Madness and Civilization: A History of Insanity in the Age of Reason. 1961. Translated by Richard Howard, Routledge Classics, 2001. 
Fourie, Bronwyn. "Point Area at Grimy Standstill." IOL, 18 June 2012, www.iol.co.za/news/south-africa/kwazulu-natal/point-area-at-grimystandstill-1321156. Accessed 30 Nov. 2015.

Frankish, Tarryn, and Jill Bradbury. "Telling Stories for the Next Generation: Trauma and Nostalgia." Peace and Conflict: Journal of Peace Psychology, vol. 18, no.3, 2012, pp. 294-306.

Frenkel, Ronit, editor. Imraan Coovadia, special issue of Current Writing: Text and Reception in Southern Africa, vol. 28, no. 1, 2016.

Frenkel, Ronit and Craig MacKenzie, editors. 'Post-Transitional' South African Literature in English, special issue of English Studies in Africa, vol. 53, no. 1, 2010.

. “Conceptualizing 'Post-Transitional' South African Literature in English." Frenkel and MacKenzie, pp. 1-10.

Freud, Sigmund. "Beyond the Pleasure Principle." 1920. The Standard Edition of the Complete Psychological Works of Sigmund Freud, vol. 18. Edited and translated by James Strachey, Hogarth Press, 1955, pp. 7-64.

. "The Uncanny." 1919. The Standard Edition of the Complete Psychological Works of Sigmund Freud, vol. 17. Edited and translated by James Strachey, Hogarth Press, 1955, pp. 219-256.

. "Mourning and Melancholia." 1917. The Standard Edition of the Complete Psychological Works of Sigmund Freud, vol. 14. Edited and translated by James Strachey, Hogarth Press, 1955, pp. 243-258.

. The Interpretation of Dreams. 1900. The Standard Edition of the Complete Psychological Works of Sigmund Freud, vols. 4 and 5. Edited and translated by James Strachey, Hogarth Press, 1964.

Freud, Sigmund, and Joseph Breuer. Studies in Hysteria. 1895. Translated by Nicola Luckhurst, Penguin Books, 2004.

Freund, Bill. The African City. Cambridge University Press, 2007.

. Insiders and Outsiders: The Indian Working Class of Durban 1910-1990. University of Natal Press, 1995.

Freund, Bill, and Vishnu Padayachee, editors. (D)urban Vortex: South African City in Transition. University of Natal Press, 2002.

Frisby, David. "The Flâneur in Social Theory." The Flâneur, edited by Keith Tester, Routledge, 1994, pp. 81-110.

Galgut, Damon. "Reality and the Novel." New Contrast, vol. 18, no.1, 1990, pp. 51-55.

Gaylard, Gerald, editor. Marginal Spaces: Reading Ivan Vladislavić. Wits University Press, 2011. 
After Colonialism: African Postmodernism and Magical Realism. Wits University Press, 2005.

Gaylard, Rob. "Writing Black: The South African Short Story by Black Writers." Unpublished PhD dissertation, University of Stellenbosch, 2006.

Geertz, Clifford. The Interpretation of Cultures: Selected Essays. Hutchinson, 1973. Genovese, Michael A. The Watergate Crisis (Greenwood Press Guides to Historic Events of the Twentieth Century). Greenwood Press, 1999.

Gevisser, Mark. "A Different Fight for Freedom." Defiant Desire: Gay and Lesbian Lives in South Africa, edited by Mark Gevisser and Edwin Cameron, Routledge, 1995, pp. 14-88.

"Gillespiestraat-slenters." LitNet. LitNet, Jan. 1999 - Apr. 2001, www.oulitnet. co.za/gillespie/2000_01.asp. Accessed 01 Aug. 2017.

Gilroy, Paul. The Black Atlantic: Modernity and Double Consciousness. Verso, 1993.

Giraut, Frédéric, and Céline Vacchiani-Marcuzzo. Territories and Urbanisation in South Africa: Atlas and Geo-Historical Information System (DYSTURB). Cartes et Notices No. 117. IRD Éditions, 2009.

Gobodo-Madikizela, Pumla, and Chris van der Merwe, editors. Memory, Narative and Forgiveness: Perspectives on the Unfinished Journeys of the Past. Cambridge Scholars Publishing, 2009.

Goodman, Ralph. "The Man, the Woman and the Whale: Exploring the Politics of the Possible in Zakes Mda's The Whale Caller." Current Writing: Text and Reception in Southern Africa, vol. 20, no. 1, pp. 105-118.

Gordon, Lewis R. "Is Philosophy Blue?" The Johannesburg Salon, vol. 7, 2014, pp. 15-20, www.jwtc.org.za. Accessed 28 Sept. 2017.

Govinden, Devarakshanam B. "Healing the Wounds of History: South African Indian Writing." Chapman and Lenta, pp. 283-298.

. A Time of Memory: Reflections on Recent South African Writers. Solo Collective, 2008.

Graham, Shane. South African Literature after the Truth Commission: Mapping Loss. Palgrave Macmillan, 2009.

Grant, Richard. Globalizing City: The Urban and Economic Transformation of Accra, Ghana. Syracuse University Press, 2009.

Greenberg, Louis, editor. Home Away: 24 Hours, 24 Cities, 24 Authors. Zebra Press, 2010.

Greshoff, Jan. The Last Days of District Six. District Six Museum, 1996. 
Grest, Jeremy. "Urban Citizenship and Legitimate Governance: The Case of the Greater Warwick Avenue and Grey Street Urban Renewal Project, Durban." Transformation: Critical Perspectives on South Africa, no. 48, 2002, pp. 38-58.

Guex, Germaine. La Nérvose d'Abandon. Presses Universitaires de France, 1950. Gupta, Pamila. "The Future(s) of (Colonial) Nostalgia or Ruminations on Ruins." The Johannesburg Salon, vol. 1, 2009, pp. 55-57, www.jwtc.org.za. Accessed 02 Dec. 2015.

Günzel, Stefan. "Spatial Turn - Topographical Turn - Topological Turn: Über die Unterschiede zwischen Raumparadigmen." Spatial Turn: Das Raumparadigma in den Kultur- und Sozialwissenschaften, edited by Jörg Döring and Tristan Thielmann, Transcript Verlag, 2008, pp. 219-240. , editor. Topologie: Zur Raumbeschreibung in den Kultur- und Medienwissenschaften. Transcript Verlag, 2007.

. "Raum - Topographie - Topologie." Günzel, Topologie, pp. 13-29. . "Einführung: Spatial Turn, Topographical Turn, Topological Turn." Topologie: WeltRaumDenken. Symposium at the Bauhaus-Universität Weimar, 10 Nov. 2005. www.de.scribd.com/doc/82766445/GuenzelTopologie-Einfuehrung. Accessed 10 Aug. 2012.

Haffajee, Ferial. What If There Were No Whites in South Africa? Picador Africa, 2015.

Hallett, George, and Peter McKenzie. District Six Revisited. Wits University Press, 2007.

Herne, Lily. Ash Remains. Constable and Robinson, 2014. . The Army of the Lost. Constable and Robinson, 2013. . Death of a Saint. Constable and Robinson, 2013. . Deadlands. Constable and Robinson, 2011.

Harré, Rom, and Fathali M. Moghaddam. "Historicity, Social Psychology and Change." History, Historicity and Science, edited by Tom Rockmore and Joseph Margolis, Ashgate Publishing, 2006, pp. 95-120.

Hart, Deborah M. "Political Manipulation of Urban Space: The Razing of District Six, Cape Town." Jeppie and Soudien, pp. 117-142.

Harvey, David. "The Right to the City." New Left Review, vol. 53, no. 5, 2008, pp. 23-40.

Hassim, Aziz. The Lotus People. STE Publishers, 2003.

la Hausse, Paul. "The Struggle for the City: Alcohol, the Ematsheni and Popular Culture in Durban, 1902-1936." Maylam and Edwards, pp. 33-66. 
Hemson, David. "In the Eye of the Storm: Dock-Workers in Durban." Maylam and Edwards, pp. 145-173.

. "Class Consciousness and Migrant Workers: Dockworkers of Durban." Unpublished PhD Thesis, University of Warwick, 1979.

Hepworth, Russell. "The Black South Easter." Cape Point Chronicle, 16 Nov. 2013, www.capepointchronicle.co.za/2013/11/16/the-black-southeaster/. Accessed 11 Aug. 2015.

Hess, Lauren. "Rhodes Statue to Be Removed from UCT, and Mugabe Gives His Opinion." Mail\&Guardian, 09 Apr. 2015, www.mg.co.za/article /2015-04-09-rhodes-statue-to-be-removed-after-uct-council-decision. Accessed 28 Sept. 2017.

Heywood, Christopher. A History of South African Literature. Cambridge University Press, 2004.

Hirsch, Marianne. "The Generation of Postmemory." Poetics Today, vol. 29, no. 1, 2008, pp. 103-128.

Hlongwane, Perfect. Jozi: A Novel. University of KwaZulu-Natal Press, 2013.

Hodes, Rebecca. "Junkyard Promenade: The Corporate Vandalism of the Sea Point Beachfront." Daily Maverick, 11 Nov. 2014, www.dailymaverick.co.za/article/2014-11-11-junkyard-promenade-thecorporate-vandalism-of-the-sea-point-beachfront/\#.WcwZ3 RRzU5k. Accessed 24 July 2017.

Hook, Derek. (Post)Apartheid Conditions: Psychoanalysis and Social Formation (Studies in the Psychosocial). Palgrave MacMillan, 2013.

Human, Charlie. Kill Baxter. Umuzi, 2014. . Apocalypse Now Now. Umuzi, 2013.

Jaffer, Kay. "Notions of Coloured Identities in Cape Flats Theatre: A Look at Taliep Petersen's District Six - The Musical." South African Theatre Journal, vol. 12, no. 1-2, 1998, pp. 91-107.

Jamal, Ashraf. "Bullet Through the Church: South African Literature in English and the Future-Anterior." English Studies in Africa, vol. 53, no. 1, 2010, pp. 11-20.

. Love Themes for the Wilderness. Kwela Books, 1996.

Jeppie, Shamil, and Crain Soudien, editors. The Struggle for District Six: Past and Present. Buchu Books, 1990.

"Johan van Wyk." KZN Literary Tourism, n.d., www.literarytourism.co.za /index.php?option=com_content\&view=article\&id=379:johan-van-wyk\& catid=13:authors\& Itemid=28. Accessed 30 Nov. 2015. 
Johns, Timothy. "The Price of Pleasure: K. Sello Duiker's Thirteen Cents and the Economics of Homosexuality in South Africa." Masculinities in African Literary and Cultural Texts, edited by Helen Nabasuta Mugambi and Tuzyline Jita Allan, Lynne Rienner Books for Ayebia Clarke Publishing, pp. 250-269.

Joseph, Norman. “Gay Bar Bomb 'Was Home-Made.'” IOL, 8 Nov. 1999, www.iol.co.za/news/south-africa/gay-bar-bomb-was-home-made18800. Accessed 26 July 2017.

Joseph-Vilain, Mélanie. “Un Posthumain Post-apartheid? Moxyland et Zoo City de Lauren Beukes." Post Humains: Frontières, Evolutions, Hybridités, edited by Elaine Després and Hélène Machinal, Presses Universitaires de Rennes, 2015, pp. 165-177.

. "Corps et Corporalité dans Moxyland de Lauren Beukes." Les Frontières de l'Humain et le Posthumain (Collection Figura, vol. 37), edited by MarieEve Cléroux and Jean-François Chassay, UQAM, 2014, pp. 73-89.

Judin, Hilton, and Ivan Vladislavić, editors. Blank - Architecture, Apartheid and After. NAI Publishers, 1998.

Kamanzi, Brian. "Hyperreality in the Colonised World." The Johannesburg Salon, vol. 9, 2015, pp. 102-104, www.jwtc.org.za/resources/docs/salonvolume-9/Brian_Hyperreality_Vo19_30.pdf. Accessed 30 Aug. 2017.

Kapstein, Helen. "Coffins, Corpses and Wheelchairs: Mass Hysteria and Postcolonial Constitutions." Studies in Humanities, vol. 39, no. 1, 2012, pp. 46-71.

. "A Culture of Tourism: Branding the Nation in a Global Market." Safundi: The Journal of South African an American Studies, vol. 8, no. 1, 2007, pp. 109-115.

Keller, Richard C. Colonial Madness: Psychiatry in French North Africa. University of Chicago Press, 2007.

Kirby, Chris. "The Point Re-Visited: A Redevelopment Plan for the Point Road Precinct in Durban." Unpublished MA thesis, University of Cape Town, 2014.

Kit, Borys, and Andy Lewis. "Hot Book The Shining Girls Acquired by MRS, DiCaprio's Appian Way." The Hollywood Reporter, 31 May 2013, www.hollywoodreporter.com/heat-vision/hot-book-shining-girlsacquired-561252. Accessed 10 Aug. 2015.

Kleinboer. “Digters Gaan Dood Om Jou.” Boeke-Insig, 1 April 2009, p. 30. 
de Kock, Leon. "Capitalism's Not a White Thing." Mail\&Guardian, 16 Sept. 2011, www.mg.co.za/article/2011-09-16-capitalisms-not-a-white-thing. Accessed 4 Nov. 2015.

. "The End of 'South African' Literary History?: Judging 'National' Fiction in a Transnational Era." Chapman and Lenta, pp. 19-49.

. "The Call of the Wild: Speculations on a White Counterlife in South Africa." Whiteness Studies: A South African Perspective, special issue of English in Africa, vol. 37, no. 1, 2010, pp. 15-39.

. "Notes on the Construction of 'South African English Writing.'” English Studies in Africa, vol. 53, no. 1, 2010, pp. 108-112.

. "Blanc de Blanc: Whiteness Studies - A South African Connection?" Journal of Literary Studies, vol. 22, no. 1, 2006, pp. 175-189.

. "South Africa in the Global Imaginary: An Introduction." Poetics Today, vol. 22, no. 2, 2001, pp. 263-298.

Klopper, Dirk. "The Place of Nostalgia in Zoë Wicomb's Playing in the Light." Current Writing: Text and Reception in Southern Africa, vol. 23, no. 2, 2011, pp. 147-156.

Kostelac, Sofia. “'Impostor, Lover and Guardian': Damon Galgut and Authorship in 'Post-Transition' South Africa." English Studies in Africa, vol. 53, no. 1, 2010, pp. 53-61.

Kramer, David, and Taliep Petersen. Kat and the Kings. First Night Records, 1998. . District Six - The Musical. Priority Records, 1986.

Kristeva, Julia. Powers of Horror: An Essay on Abjection. 1980. Translated by Leon S. Roudiez, Columbia University Press, 1982.

Kruger, Loren. Imagining the Edgy City: Writing, Performing, and Building Johannesburg. Oxford University Press, 2013.

Kutler, Stanley I. The Wars of Watergate: The Last Crisis of Richard Nixon. Knopf, 1990.

KZN Literary Tourism. KZN Literary Tourism, n.d., www.literarytourism.co.za. Accessed 17 Sept. 2017.

Lacan, Jacques. Écrits. 1966. Translated by Bruce Fink, W. W. Norton, 2007. . The Seminar of Jacques Lacan Book III: The Psychoses 1955-1956. Edited by Jacques-Alain Miller, translated by Russell Grigg, W. W. Norton, 1981.

La Guma, Alex. A Walk in the Night and Other Stories. 1962. Trent Editions, 2006.

Laing, Robert D. The Divided Self: An Existential Study in Sanity and Madness. 1964. Routledge Classics, 2017. 
Landau, Loren B., editor. Exorcising the Demons within: Xenophobia, Violence and Statecraft in Contemporary South Africa. United Nations University Press, 2011.

Landsman, Ann. The Rowing Lesson. Kwela Books, 2007.

Last Supper in Hortsley Street. Directed by Linda Wilson. Linda Wilson Productions, 1983.

Laubscher, Leswin. "Of Odysseus and Abraham: Nostalgia, Heimweë, and the Ways (of) Home." Peace and Conflict: Journal of Peace Psychology, vol. 18, no. 3, 2012, pp. 214-224.

Lauren Beukes, n.d., www.laurenbeukes.com. Accessed 11 Aug. 2015.

Lefebvre, Henri. The Production of Space. 1974. Translated by Donald Nicholson-Smith, Blackwell Publishers, 1991.

Legg, Stephen. "Memory and Nostalgia." Cultural Geographies, vol. 11, 2004, pp. 99-107.

Lenta, Margaret. “Expanding 'South Africanness': Debut Novels." Chapman and Lenta, pp. 50-68.

Lessing, Carel. “Die Skrywer by Sy Mense.” Insig, 28 February 2002, p. 45.

Long, Carol. "Transitioning Racialised Spaces." Race, Memory and the Apartheid Archive: Towards a Transformative Psychological Praxis, edited by Garth Stevens et al., Palgrave Macmillan, 2013, pp. 61-80.

López, María J. “Doomed to Walk the Night: Ghostly Communities and Promises in the Novels of Alex La Guma." Community in Twentieth-Century Fiction, edited by Paula Martín Slaván et al., Palgrave Macmillan, 2013, pp. 123-140.

Lovell, Jeremy. "Bomb Outside Cape Town Nightclub Injures One." IOL, 20 Aug. 2000, www.iol.co.za/news/south-africa/bomb-outside-cape-townnightclub-injures-one-47726. Accessed 26 July 2017.

Maart, Rozena. Personal Interview. 12 and 17 March 2015. . "Philosophy Born of Massacres - Maricana, the Theatre of Cruelty: the Killing of the "kaffir.'" Acta Academica: Critical Views on Society, Culture and Politics, vol. 46, no. 4, 2014, pp. 1-28. . The Writing Circle. TSAR Books, 2007. . Rosa's District Six. TSAR Books, 2004. . Talk About It! Williams-Wallace Publishers, 1990.

Machen, Peter. "Of Love, Literature and Beauty Pageants." News 24, 10 Feb. 2008, www.news24.com/archives/witness/of-love-literature-and-beauty -pageants-20150430. Accessed 1 Nov. 2014. 
Mainet-Valleix, Hélène. Durban: Les Indiens, leurs Territoires, leur Identité. Karthala, 2002.

Malory, Thomas. Le Morte D'Arthur (Norton Critical Editions), edited by Stephen H. A. Shepherd, W.W. Norton and Company, 2004.

Mamet, Claudia. "Re-constructing Grey Street in Imraan Coovadia's The Wedding." Alternation, vol. 15, no. 2, 2008, pp.71-90.

. "Fictional Constructions of Grey Street by Selected South African Indian Writers." Unpublished MA thesis, University of KwaZulu-Natal, 2007.

Manda, Sihle, et al. "Violence Has Durban on the Edge." IOL, 15 Apr. 2015, www.iol.co.za/news/crime-courts/violence-has-durban-on-the-edge1845192. Accessed 4 Dec. 2015.

Mansfield, Nick. Subjectivity: Theories of the Self from Freud to Haraway. New York University Press, 2000.

Manuel, George, and Denis Hatfield. District Six. Longmans, 1967.

Maran, René. Un Homme Pareil aux Autres. Editions Arc-en-Ciel, 1947.

"Mariam Akabor." KZN Literary Tourism. KZN Literary Tourism, n.d., www.literarytourism.co.za/index.php?option $=$ com_content\&view $=$ articl e\&id=109: mariam-akabor\&catid=13:authors\&Itemid=28. Accessed 16 Sept. 2015.

Marlowe, Christopher. "The Passionate Shepherd to His Love." The Norton Anthology of Poetry, edited by Margaret Ferguson et al., W. W. Norton and Company, pp. 233-234.

Marrian, Natasha. "Mbeki Seeks to Overturn 'Untruths' about His Presidency." Business Day, 11 Jan. 2016, www.bdlive.co.za/national/ politics/2016/01/11/mbeki-seeks-to-overturn-untruths-about-hispresidency. Accessed 31 March 2016.

Masschelein, Anneleen. The Unconcept: The Freudian Uncanny in Late-TwentiethCentury Theory. SUNY Press, 2011.

Massey, Doreen. For Space. Sage Publications, 2005.

Power-Geometries and the Politics of Space-Time: Hettner-Lectures 1998. Gruckagentur Jürgen-J. Sause, 1999.

. Space, Place and Gender. Polity Press, 1994.

"Power-Geometry and a Progressive Sense of Place." Mapping the Futures: Local Cultures, Global Change, edited by John Bird et al., Routledge, 1993, pp. 59-69.

. "Politics and Space/Time." New Left Review, no. 196, 1992, pp. 65-84.

Maurice, Emile, editor. District Six: Image and Representation. South African National Gallery and District Six Museum, 1995. 
Maylam, Paul, and Iain Edwards, editors. The People's City: African Life in Twentieth-Century Durban. University of Natal Press/Heinemann, 1996.

Mbembe, Achille. "Rule of Property versus Rule of the Poor?" Mail\&Guardian, 15 June 2012, www.mg.co.za/article/2012-06-15-rule-of-property-versusrule-of-the-poor. Accessed 10 Sept. 2017.

. "Aesthetics of Superfluity." Nuttall and Mbembe, pp. 37-67.

. On the Postcolony (Studies on the History of Society and Culture, vol. 41). University of California Press, 2001.

Mbeki, Thabo. "The Tragedy of History: When Caricature Displaces the Truth." Thabo Mbeki Foundation, 11 Jan. 2016, www.mbeki.org. Accessed 31 March 2016.

. "Behind the Narrative of the Abuse of State Power Was a Larger Goal." Thabo Mbeki Foundation, 8 Feb. 2016, www.mbeki.org. Accessed 31 March 2016

. "A Brief Commentary on the Question of HIV and AIDS." Thabo Mbeki Foundation, 7 March 2016, www.mbeki.org. Accessed 31 March 2016.

. "Some Observations on HIV \& Mortality in South Africa: 2007, 2008 and 2013." Thabo Mbeki Foundation, 14 March 2016, www.mbeki.org. Accessed 31 March 2016.

McCabe, Douglas. "'Higher Realities': New Age Spirituality in Ben Okri's The Famished Road." Research in African Literatures, vol. 36, no. 4, 2005, pp. 1-21.

McCormick, Kay. Language in Cape Town's District Six. Oxford University Press, 2002.

McKaiser, Eusebius. Run Racist Run: Journeys into the Heart of Racism. Bookstorm, 2015.

. “Confronting Whiteness." MailEGuardian, 1 July 2011, www.mg.co.za/ article/2011-07-01-confronting-whiteness. Accessed 4 Nov. 2015.

McNulty, Bridget. "Re: Quick Question." Received by Olivier Moreillon, 19 Jan. 2015.

. Strange Nervous Laughter. 2007. Thomas Dunne Books, 2009.

"Politics in Fiction: Yes or No?" Thought Leader, 15 Nov. 2007, www.thoughtleader.co.za/bridgetmcnulty/2007/11/15/politics-infiction-yes-or-no/. Accessed 1 Nov. 2014.

McNulty, Niall. "Reading the City: Analysing Literary Space in Selected Postapartheid Urban Narratives." Unpublished MA thesis, University of KwaZulu-Natal, 2005. 
McNulty, Niall, and Lindy Stiebel. A Literary Guide to KwaZulu-Natal. University of KwaZulu-Natal Press, 2017.

. "Grey Street Writers Trail." KZN Literary Tourism. KZN Literary Tourism, 2006, www.literarytourism.co.za/index.php?option=com_content\& view $=$ article\&id=68:grey-street-writers-trail\&catid=16:trails\&Itemid=30.

Accessed 11 March 2015.

Meadon, Angela. A Taste of You. Damnation Books, 2012.

Medalie, David. "The Uses of Nostalgia." English Studies in Africa, vol. 53, no. 1, 2010, pp. 35-44.

Mda, Zakes. The Sculptors of Mapungubwe. Seagull Books, 2013. . The Whale Caller. Picador, 2005. .Ways of Dying. Picador, 1995.

Mengel, Ewald, and Michela Borzaga, editors. Trauma, Memory and Narrative in the Contemporary South African Novel: Essays. Rodopi, 2012.

Merten, Marianne. "Sea Point 'Unrecognisable' as Gangs Move in." MailEGuardian. 31 Jan. 2003, www.mg.co.za/article/2003-01-31-seapoint-unrecognisable-as-gangs-move-in. Accessed 6 Feb. 2017.

van der Merwe, Annari. "In Memoriam." LitNet, 20 Jan. 2005, www.oulitnet.co.za/inmemoriam/duiker_dies.asp. Accessed 7 Aug. 2017.

Mesthrie, Uma Shashikant. "The Tramway Road Removals, 1959-61." Kronos, vol. 21, 1994, pp. 61-78.

Meyer, Jani. "Is Durban the Drug Capital of the Country?" IOL, 14 March 2003, www.iol.co.za/news/south-africa/is-durban-the-drug-capital-ofthe-country-102986. Accessed 4 Dec. 2015.

Mhlongo, Niq. Affluenza. Kwela Books, 2016.

Way Back Home. Kwela Books, 2013.

After Tears. Kwela Books, 2007.

. Dog Eat Dog. Kwela Books, 2004.

Miller, Colin. "Julle kan ma New York toe gaan, ek bly in die Manenberg': An Oral History of Jazz in Cape Town from the mid-1950s to the mid-1970s." Imagining the City: Memories and Cultures in Cape Town, edited by Sean Field et al., HSRC Press, 2007, pp. 133-149.

Miller, Penny. Myths and Legends of Southern Africa, edited by Rosemund Handler, T. V. Bulpin Publications, 1979.

Miraftab, Faranak. "Governing Post Apartheid Spatiality: Implementing City Improvement Districts in Cape Town." Antipode, vol. 39, no. 4, 2007, pp. 602-626. 
Misgun, Biniam, and Wesley Oakes. "The White and Black Sands of the Durban Beachfront." Pattman and Khan, pp. 118-125.

Mnxqitama, Andile. "End of Whiteness a Black Issue." Mail\&Guardian, 24 Oct. 2011, www.mg.co.za/article/2011-10-24-end-to-whiteness-a-black-issue. Accessed 4 Nov. 2015.

Moller, Valerie, and Lawrence Schlemmer. Attitudes Towards Beach Integration: A Comparative Study of Black and White Reactions to Multiracial Beaches in Durban. Centre of Applied Social Sciences, University of Natal, 1982.

Moreillon, Olivier, et al., editors. Cities in Flux: Metropolitan Spaces in South African Literary and Visual Texts - Festschrift in Honour of Prof. em. Dr. Therese Steffen (Swiss Society for African Studies, vol. 12). LIT Verlag, 2017. . Introduction. Olivier Moreillon et al., pp. 1-14.

Moreillon, Olivier, and Alan Muller. "Half 'n Half: Mytho-Historical and Spatial Entanglements in Charlie Humans's Apocalypse Now Now and Kill Baxter." Memory, Heritage and the Politics of Transformation: The Place of 'Colonial' Texts in Post-2000 South Africa and Zimbabwe, special issue of Journal of Literary Studies, vol. 32, no. 3, 2016, pp. 77-97.

Moretti, Franco. "Conjectures on World Literature." Distant Reading, Verso, 2013, pp. 43-62.

Morris, Brittany, et al. "How Visualising Newspaper History of a Neighbourhood Can Shed Light on the Future." Future Cape Town, 11 Aug. 2015, www.futurecapetown.com/ 2015/08/future-cape-town-how-visualisingthe-newspaper-history-of-a-neighbourhood-can-shed-light-on-thefuture/. Accessed 6 Feb. 2017.

Morrison, Toni. Beloved. 1987. Vintage, 2005.

. The Bluest Eye. 1970. Vintage, 1999.

Mouralis, Bernard. L'Europe, l'Afrique et la folie. Présence Africaine, 1993.

Moxie. Moxie Beverage Company, n.d., www.drinkmoxie.com. Accessed 11 Aug. 2015.

Muller, Alan. "'A Handful of Spaghetti': South/South Migration and the City in Imraan Coovadia's The Wedding." Olivier Moreillon et al., pp. 171-192.

- "Cosmopolitan Criminality: Cultural Entanglements and Globalised Crime in Imraan Coovadia's Green-Eyed Thieves." Imraan Coovadia, special issue of Current Writing: Text and Reception in Southern Africa, vol. 28, no. 1, 2016, pp. 50-61.

Muller, Carole A. South African Music: A Century of Traditions in Transformation. ABC-CLIO Inc., 2004. 
Munro, Brenna M. South Africa and the Dream of Love to Come: Queer Sexuality and the Struggle for Freedom. University of Minnesota Press, 2012.

Mupotsa, Danai. "I Was Never Ready for What Happened at Wits Yesterday." The Daily Vox, 17 Oct. 2015, www.thedailyvox.co.za/i-was-never-readyfor-what-happened-at-wits-yesterday/. Accessed 20 Aug. 2017.

Murray, Jessica. "Daring to Speak Its Name: The Representation of a Lesbian Relationship in the Work of Rozena Maart." English Academy Review: Southern African Journal of English Studies, vol. 28, no. 2, 2011, pp. 52-61.

Murray, Martin J. Commemorating and Forgetting: Challenges for the New South Africa. University of Minnesota Press, 2013.

. City of Extremes: The Spatial Politics of Johannesburg. Duke University Press, 2011.

. Taming the Disorderly City: The Spatial Landscape of Johannesburg after Apartheid. Cornell University Press, 2008.

Murray, Sally-Ann. "On the Street with Vladislavić, Mhlongo, Moele and Others." Chapman and Lenta, pp. 69-96.

Mutiga, Murithi. "South African Woman Faces Criminal Charges over Racist Tweets." The Guardian, 5 Jan. 2016, www.theguardian.com/world/ 2016/jan/05/ south-african-woman-faces-criminal-charges-racist-tweets. Accessed 20 Oct. 2017.

Myers, Garth. African Cities: Alternative Visions of Urban Theory and Practices. Zed Books, 2011.

"My Word! Redesigning Buckingham Palace." Baxter Theatre Centre, n.d., www.baxter.co.za/shows/my-word-redesigning-buckingham-palace/. Accessed 3 Sept 2015.

Mzamane, Mbulelo Vizikhungo, editor. Words Gone Two Soon: A Tribute to Phaswane Mpe and K. Sello Duiker. Umgangatho Media \& Communications, 2005. . Introduction. Mzamane, pp. xi-xviii.

Ndebele, Njabulo S. South African Literature and Culture: Rediscovery of the Ordinary. Manchester University Press, 1994.

Ngom, Mamadou Abdou Babou. “Thirteen Cents by K. Sello Duiker: Exposing Street Child Reality in South Africa." The Journal of Pan African Studies, vol. 6, no. 9, 2014, pp. 44-57.

van Niekerk, Barend. Durban at Your Feet: An Alternative Guide to a City. Overport Publishers, 1979.

van Niekerk, Marlene. Triomf. Translated by Leon de Kock, Jonathan Ball Publishers/Queillerie Publishers, 1999. 
Nkosi, Lewis. "The World of Johan van Wyk." Unpublished Essay written in 2001. 1-15.

. "Die Freiheit der Desillusionierten." Neue Zürcher Zeitung, 27 July 2002, www.nzz.ch/article8AGOU-1.412050. Accessed 4 Apr. 2012.

. Mating Birds. Constable, 1986.

. Home and Exile: And Other Selections. 1965. Longman Inc., 1983.

Nopens, Horst W. Die rechtliche Ausgestaltung der Apartheid am Beispiel des Group Areas Act No. 36 of 1966 (Europäische Hochschulschriften Reihe II Rechtswissenschaften 2779). Peter Lang, 2000.

Nora, Pierre. "Between Memory and History: Les Lieux de Mémoire." Representations, vol. 26, 1989, pp. 7-24.

Now Novel. Now Novel CC, 2014, www.nownovel.com. Accessed 1 Nov. 2014.

Nuttall, Sarah. Entanglement: Literary and Cultural Reflections on Post-Apartheid. Wits University Press, 2009.

. "Literary City." Nuttall and Mbembe, pp. 195-218.

Nuttall, Sarah, and Achille Mbembe, editors. Johannesburg: The Elusive Metropolis. Duke University Press, 2008.

. "Writing the World from an African Metropolis." Public Culture vol. 16, no. 3, 2004, pp. 347-372.

Okri, Ben. The Famished Road. Jonathan Cape, 1991.

Olson, Keith W. Watergate: The Presidential Scandal that Shook America. University Press of Kansas, 2003.

Otter, Charlotte. "Poets and Politics." Charlotte's Web, 12 Nov. 2007, www.charlotteotter.wordpress.com/2007/11/12/poets-and-politics/.

Accessed 1 Nov. 2014.

Oxford English Dictionary. Edited by John A. Simpson and Edmund S. C. Weiner, Claredon Press, 1989.

Oxford Dictionaries. Oxford University Press, 2017, www.oxforddictionaries. com. Accessed 13 Aug. 2017.

Paton, Alan. Cry, the Beloved Country. Charles Scribner's Sons, 1948.

Pattman, Rob, and Sultan Kahn, editors. Undressing Durban: Behind the Tourist Gaze. Madiba Publishers, 2007.

Paulse, Michele. "An Oral History of Tramway Road and Ilford Street, Sea Point, 1930s-2001: The Production of Place by Race, Class and Gender." Unpublished PhD thesis, University of Cape Town, 2002.

Penfold, Tom. "Public and Private Space in Contemporary South Africa: Perspectives from Post-Apartheid Literature." Journal of South African Studies, vol. 38, no. 4, 2012, pp. 993-1006. 
Perkins Gilman, Charlotte. "The Yellow Wall-Paper." 1892. The Yellow WallPaper, Herland, and Selected Writing, edited by Denise D. Knight, Penguin Books, 2009, pp. 166-182.

Perry, Ann C., and Jared Shurin, editors. Pandemonium: Stories of the Apocalypse. Jurassic London, 2011.

Peterson, Bhekizizwe. "Kwaito, 'dawgs' and the Antimonies of Hustling." African Identities, vol. 1, no. 2, 2003, pp. 197-213.

Petzer, Brett. "Sea Point: Can the Reallest Atlantic Suburb Hold Its Own against Gentrification?" Future Cape Town. Future Cape Town, 17 Feb. 2014, www.futurecapetown.com/2014/02/ sea-point-can-the-reallestatlantic-suburb-hold-its-own-against-gentrification/\#.WcySEhRzU5k.

Accessed 6 Feb. 2017.

Phillip, Bulelani. "Cape on the Road to Billion-Rand Facelift." IOL, 31 Aug. 2006, www.iol.co.za/news/south-africa/cape-on-the-road-to-billion-rand -facelift-291787. Accessed 26 July 2017.

Phoenix, Alexander. "Spectacles of Dystopia: Lauren Beukes and the Geopolitics of Digital Space." Safundi: The Journal of South African an American Studies, vol. 16, no. 2, 2015, pp. 156-172.

Pietikainen, Petteri. Madness: A History. Routledge, 2015.

Pilane, Pontsho. "Penny Sparrow: Can Racism Be Outlawed in South Africa?" MailEGuardian, 4 Jan. 2016, www.mg.co.za/article/2016-01-04-pennysparrow-can-racism-be-outlawed-in-south-africa. Accessed 20 Oct. 2017.

Pirie, Gordon. "Reanimating a Comatose Goddess: Reconfiguring Central Cape Town." Urban Forum, vol. 18, no. 3, 2007, pp. 125-151.

. "Researching Cape Town, 1990-2004." Urban Forum, vol. 16, no. 4, 2005, pp. 336-351.

Pongoma, Luzuko. "MSHENGU Is No More." Sowetan LIVE, 21 July 2009, www.sowetanlive.co.za/sowetan/archive/2009/07/21/mshengu-is-nomore. Accessed 25 March 2016.

Porter, Roy. Madness: A Brief History. Oxford University Press, 2002.

Posel, Deborah. "Races to Consume: Revisiting South Africa's History of Race, Consumption and the Struggle for Freedom." Ethnic and Racial Studies, vol. 33, no. 2, 2010, pp. 157-175.

. "Race as Common Sense: Racial Classification in Twentieth-Century South Africa." African Studies Review, vol. 44, no. 2, 2001, pp. 87-113.

. "What's in a Name? Racial Categorisation under Apartheid and their Afterlife." Transformation: Critical Perspectives on South Africa, vol. 47, 2001, pp. 50-74. 
Powers, Jessica L. "The Politics of Crime: South Africa's New Socially Conscious Genre." World Literature Today, vol. 89, no. 2, 2015, 30-33.

Radithlalo, Sam. "A Victory of Sorts, All Thirteen Cents and Bitter, too." Canadian Review of Comparative Literature/Revue Canadienne de Littérature Comparée, vol. 37, no. 3, 2010, pp. 266-279.

. “'The Travelling Salesman': A Tribute to K. Sello Duiker 1974-2005." Feminist Africa, vol. 5, 2005, pp. 96-104.

Randels, W. G. L. L'Empire du Monomotapa du XVe au XIXe Siècle (Ecole des Hautes Etudes en Sciences Sociales, Centre de Recherches Historiques, Civilisation et Sociétés 46). Mouton, 1975.

Rassool, Ciraj, and Sandra Prosalendis, editors. Recalling Community in Cape Town: Creating and Curating the District Six Museum. District Six Museum, 2001.

Reddy, Shanta. "Sometime Crass \& Vile But Also Relentlessly Honest." Independent on Saturday, 21 Apr. 2001, p. 12. Print.

Richards, Jo-Anne. The Innocence of Roast Chicken. Headline Book Publishing, 1996.

Rimmon-Kenan, Shlomith. Narrative Fiction: Contemporary Poetics. $2^{\text {nd }}$ ed., Routledge, 2002.

Rive, Richard. "District Six: Fact and Fiction." Jeppie and Soudien, pp. 110-116.

.'Buckingham Palace', District Six. David Philip Publishers, 1986.

Robinson, Jennifer. Ordinary Cities: Between Modernity and Development. Routledge, 2006.

. The Power of Apartheid: State, Power and Space in South African Cities. Butterworth-Heinemann, 1996.

Rocchi, Jean-Paul. "Intersecting Identities and Epistemologies in Rozena Maart's 'No Rosa, No District Six.'” Postcoloniality - Decoloniality - Black Critique: Joints and Fissures, edited by Sabine Broeck, Campus, 2014, pp. 369-388.

. "Literature and the Meta-Psychoanalysis of Race." Palimpsest: A Journal of Women, Gender and the Black International, vol. 1, no. 1, 2012, pp. 52-67.

. "Walls as Words as Weapons as Womb as 'Woooooow'; Fente murale, fente $t / \operatorname{sex}(u)$ [elle], fondu identitaire: Jouir/écrire ou la post-identité dans 'No Rosa, No District Six' de Rozena Maart." Image de Soi dans les Sociétés Postcoloniales (Actes du colloque de l'Université des Antilles et de la Guyane), edited by Patricia Donatien-Yssa, Editions le Manuscrit, 2006, pp. 179-215. 
Rohleder, Paul, et al., editors. HIV/AIDS in South Africa 25 Years On: Psychological Perspectives. Springer, 2009.

Roos, Henriette. "Art and/as Anarchy: Portraying the Artist during Times of Turmoil and War." Journal of Literary Studies, vol. 26, no. 4, 2010, pp. 36-56.

Rosenberg, Leonard. Introduction. Rosenberg et al., pp. 6-11. . "The Spatial Evolution of Durban." Rosenberg, et al., pp. 12-36.

Rosenberg, Leonard, et al., editors. The Making of Place: The Warwick Junction Precinct: 1870s-1980s. Durban University of Technology, 2013.

Rosenthal, Jane. "South African Fiction." Mail\&Guardian, 06 Nov. 2007, www.mg.co.za/article/2007-11-06-south-african-fiction. Accessed 1 Nov. 2014.

Rozena Maart. WordPress, n.d., www.rozenamaart.wordpress.com. Accessed 02 Dec. 2015.

Samuelson, Meg. "(Un)Lawful Subjects of Company." Interventions: International Journal of Postcolonial Studies, vol. 16, no. 6, 2014, pp. 795-817. . "Sea Changes, Dark Tides and Littoral States: Oceans and Coastlines in Post-Apartheid South African Narratives." Alternation, vol. 6, 2013, pp. 9-28.

- "Oceanic Histories and Protean Poetics: The Surge of the Sea in Zoë Wicomb's Fiction." Journal of Southern African Studies, vol. 36, no.3, 2010, pp. 543-557.

. "Scripting Connections: Reflections on the 'Post-Transitional.'" English Studies in Africa, vol. 53, no. 1, 2010, pp. 113-117.

. "Walking through the Door and Inhabiting the House: South African Literary Culture and Criticism after the Transition." English Studies in Africa, vol. 51, no. 1, 2008, pp. 130-137.

. Remembering the Nation, Dismembering Women? Stories of the South African Transition. University of KwaZulu-Natal Press, 2007.

. "The City beyond the Boarder: The Urban Worlds of Duiker, Mpe and Vera." African Identities, vol. 5, no. 2, 2007, pp. 247-260.

Sartre, Jean-Paul. Preface. The Wretched of the Earth, by Frantz Fanon, Présence Africaine, 1963, pp. 7-31.

Saunders, Tracey. "Channelling Dulcie September." Cape Times, 12 May 2015, www.iol.co.za/capetimes/arts-portal/stage/channelling-dulcieseptember-1857338. Accessed 3 Sept. 2015.

Scarry, Elaine. The Body in Pain: The Making and Unmaking of the World. Oxford University Press, 1985. 
Schmidt, Jennifer M. "Ghost Girls and Sponsorbabes: Dystopian Performances of White Femininity in Lauren Beukes's Moxyland." Scrutiny2: Issues in English Studies in Southern Africa, vol. 19, no. 1, 2014, pp. 109-118.

Schmidt, Jennifer M., and Mary West, editors. Whiteness Studies: A South African Perspective, special issue of English in Africa, vol. 37, no.1, 2010.

Schonstein Pinnock, Patricia. Skyline. African Sun Press, 2000.

"Sea Point." South African History Online, 14 July 2011, www.sahistory.org.za/ places/sea-point. Accessed 26 July 2017.

Sea Point Days. Directed by François Verster. Luna Films, 2009.

Shakespeare, William. Romeo and Juliet, edited by Brian Gibbons, Arden Shakespeare, 2008.

. The Tempest, edited Virginia Mason Vaughan and Alden T. Vaughan, Arden Shakespeare, 2003.

. King Lear, edited by Reginald A. Foakes, Arden Shakespeare, 2003.

Sharp, Joanne P., et al., "Entanglements of Power: Geographies of Domination/Resistance." Sharp et al., pp. 1-42.

, editors. Entanglements of Power: Geographies of Domination/Resistance. Routledge, 2000.

Singh, Jaspal K., and Rajendra Chetty, editors. Trauma, Resistance, Reconstruction in Post-1994 South African Writing. Lang, 2010.

Simone, AbdouMaliq. Always Something Else: Urban Asia and Africa as Experiment (Carl Schlettwein Lectures, vol. 9), edited by Rita Kesselring et al., Basler Afrikabibliographien, 2016.

. "The Uninhabitable?: In Between Collapsed Yet Still Rigid." Cultural Politics, vol. 12, no. 2, 2016, pp. 135-154.

. "Reclaiming Black Urbanism: Inventive Methods for Engaging Urban Fields in Africa and Beyond." African Perspectives - [South] Africa: City, Society, Space, Literature and Architecture, edited by Gerhard Bruyns and Arie Graafland, 010 Publishers, 2012, pp. 30-47.

. City Life from Jakarta to Dakar: Movements at the Crossroads. Routledge, 2010.

. For the City Yet to Come: Changing African Life in Four Cities. Duke University Press, 2004.

Simone, AbdouMaliq, and Edgar Pieterse. New Urban Worlds: Inhabiting Dissonant Times. Polity Press, 2017.

Smit, Johannes A., et al., editors. Rethinking South African Literary History. Y Press, 1996. 
Smith, David. "South Africa Faces Backlash over Xenophobic Attacks on Migrant Workers." The Guardian, 19 Apr 2015, www.theguardian.com/ world/2015/apr/18/south-africa-migrant-workers-protests. Accessed 18 Dec. 2015.

Smith, David M., editor. The Apartheid City and Beyond: Urbanization and Social Change in South Africa. Routledge/Wits University Press, 1992. . Living Under Apartheid: Aspects of Urbanization and Social Change in South Africa. George Allen \& Unwin, 1982.

Smith, Eric. "Third-World Punks, or, Watch Out for the Worlds Behind You." Globalization, Utopia, and Postcolonial Science Fiction: New Maps of Hope, Palgrave Macmillan, 2012, pp. 159-195.

Smith Shivambu, Janet. The Coming Revolution: Julius Malema and the Fight for Economic Freedom. Jacana Media, 2014.

Smith, Tina, and Ciraj Rassool. "History in Photographs at the District Six Museum." Rassool and Prosalendis, pp. 131-145.

Solnit, Rebecca. Wanderlust: A History of Walking. Viking, 2000.

Sontag, Susan. Illness as Metaphor and AIDS and its Metaphors. Picador, 1977, 1978/1988, 1989.

Soudien, Crain. "District Six: From Protest to Protest." Jeppie and Soudien, pp. 143-180.

Sow, Alfa Ibrahim. Anthropological Structures of Madness in Black Africa. Translated by Joyce Diamanti, International University Press, 1980.

Steyn, Melissa. 'Whiteness Just Isn't What It Used to Be': White Identity in a Changing South Africa. State University of New York Press, 2001.

Stiebel, Lindy. "Lewis Nkosi's Durban: An Indian Ocean City in Flux." Journal of the Indian Ocean Region, vol. 9, no. 2, 2013, pp. 227-237.

"Last Stop 'Little Gujarat': Tracking South African Indian Writers on the Grey Street Writers' Trail in Durban." Current Writing: Text and Reception in South Africa, vol. 22, no. 1, 2010, pp. 1-20.

. "Going on (Literary) Pilgrimage: The Development of Literary Trails with Particular Reference to KwaZulu-Natal." scrutiny2, vol. 12, no. 1, 2007, pp. 93-106.

" "Hitting the Hot Spots: Literary Tourism as a Research Field with Particular Reference to KwaZulu-Natal, South Africa." Critical Arts, vol. 18, no. 2, 2004, pp. 31-44. 
Stiebel, Lindy, and Therese Steffen, editors. Letters to my Native Soil: Lewis Nkosi Writes Home (2001-2009) (African Languages - African Literatures/Langues Africaines - Littératures Africaines, vol. 6). LIT Verlag, 2014.

Stobie, Cheryl. "Dystopian Dreams from South Africa: Lauren Beukes's Moxyland and Zoo City." African Identities, vol. 10, no. 4, 2012, pp. 367-380.

. "Somewhere in the Double Rainbow: Queering the Nation in Recent South African Fiction." Current Writing: Text and Reception in Southern Africa, vol. 15, no. 2, 2003, pp. 117-137.

"Strange Nervous Laughter by Bridget McNulty." KZN Literary Tourism, 27 Nov. 2007, www.literarytourism.co.za/index.php?option=com_content\&view $=$ article\&id=187:strange-nervous-laughter-by-bridgetmcnulty\&catid=24: reviews\&Itemid=100055. Accessed 1 Nov. 2014.

Swanson, Maynard W. “The Rise of Multicultural Durban: Urban History and Race Policy in South Africa 1830-1930." Unpublished PhD Thesis, Harvard University, 1965.

Swart, Mia. "Let's Talk about Collective Guilt." Mail\&Guardian, 15 Sept. 2011, www.mg.co.za/article/2011-09-15-lets-talk-about-collective-guilt. Accessed 4 Nov. 2015.

Sweet Life. The Editors Publishing House, 2014, www.sweetlifemag.co.za. Accessed 1 Nov. 2014.

Tester, Keith. Introduction. The Flâneur, edited by Keith Tester, Routledge, 1994, pp. 1-21.

The Bible. Authorized King James Version with Apocrypha, Oxford University Press, 1997.

"The History of LGBT Legislation." South African History Online, 12 Dec. 2014, www.sahistory.org.za/article/history-lgbt-legislation. Accessed 02 Dec. 2015.

"The History of Separate Development in South Africa." South African History Online, 20 March 2011, www.sahistory.org.za/article/history-separatedevelopment-south-africa 5. Accessed 15 Dec 2015.

Thomas, Paul L. "Challenging Science Fiction and Speculative Fiction." Introduction. Science Fiction and Speculative Fiction: Challenging Genres, edited by Paul L. Thomas, Sense Publishers, 2013, pp. 1-13.

Thurman, Christopher. "Apocalypse Whenever: Catastrophe, Privilege and Indifference (or, Whiteness and the End Times)." English Studies in Africa, vol. 58, no. 1, 2015, pp. 56-67. 
. "Places Elsewhere, Then and Now: Allegory 'Before' and 'After' South Africa's Transition." English Studies in Africa, vol. 53, no. 1, 2010, pp. 91-103.

Titlestad, Michael. "Future Tense: The Problem of South African Apocalyptic Fiction." English Studies in Africa, vol. 58, no. 1, 2015, pp. 30-41.

"Trails." KZN Literary Tourism, n.d., www.literarytourism.co.za/index. php?option=com_content\&view=category\&layout=blog\&id=16\&Itemid= 30. Accessed 9 Sept. 2017.

Turok, Ivan. "Urbanisation and Development in South Africa: Economic Imperatives, Spatial Distortions and Strategic Responses." International Institute for Environment and Development, October 2012, www.delog.org/cms/ upload/pdf-africa/Urbanisation_and_Development_in_South_Africa__Economic_Imperatives_Spatial_Distortions_and_Strategic_Responses. pdf. Accessed 31 March 2016.

uShaka Marine World. uShaka Marine World, 2017, www.ushakamarineworld. co.za. Accessed 13 Aug. 2017.

Veit-Wild, Flora. Writing Madness: Borderlines of the Body in African Literature. James Curry/Weaver Press/Jacana Media/African Academic Press, 2006. van der Velden, Elske. "Cape Town's Cape Doctor." Cape Town Magazine, n.d., www.capetownmagazine.com/cape-doctor. Accessed 11 Aug. 2015.

Vice, Samantha. "How Do I Live in This Strange Place?" Journal of Social Philosophy, vol. 41, no. 3, 2010, pp. 323-342.

Viljoen, Shaun. Richard Rive: A Partial Biography. Wits University Press, 2013. . “K. Sello Duiker's Thirteen Cents: An Introduction." Thirteen Cents, by K. Sello Duiker, Ohio University Press, 2013, pp. v-xxxiii.

. "Richard Rive: A Skewed Biography." PhD thesis, University of Witwatersrand, 2006.

. "Non-Racialism Remains a Fiction: Richard Rive's 'Buckingham Palace', District Six and K. Sello Duiker's The Quiet Violence of Dreams." English Academy Review, vol. 18, no. 1, 2001, pp. 46-53.

. "Langston Hughes and Richard Rive: Notes towards a Biography of Richard Rive." English Studies in Africa, vol. 41, no. 2, 1998, pp. 54-64.

de Villiers, David, and Mathilda Slabbert. David Kramer: A Biography. Tafelberg, 2011.

Visagie, Andries. "Global Capitalism and a Dystopian South Africa: Trencherman by Even Venter and Moxyland by Lauren Beukes." Criticism, Crisis, and Contemporary Narrative: Textual Horizons in an Age of Global Risk, edited by Paul Crosthwaite, Routledge, 2011, pp. 95-109. 
. “Wit Mans, Swart Vroue: Man-Bitch van Johan van Wyk (2001) en Kontrei van Kleinboer (2003) as Seksuele Outobiografieë." Tydskrif vir Nederlands en Afrikaans, vol. 20, no. 2, 2005, pp. 225-253.

Visser, Gustav. "Gay Men, Tourism and Urban Space: Reflections on Africa's 'Gay Capital.'” Tourism Geographies: An International Journal of Tourism Space, Place and Environment, vol. 5, no. 2, 2003, pp. 168-189.

Visser, Irene. "Trauma Theory and Postcolonial Literary Studies." Journal of Postcolonial Writing, vol. 47, no. 3, 2011, pp. 270-282.

Vladislavić, Ivan. The Exploded View. Random House, 2004. . The Restless Supermarket. David Philip Publishers, 2001.

van der Vlies, Andrew. "The Art and Politics of Alex La Guma." Journal of Southern African Studies, vol. 37, no. 2, 2011, pp. 392-394.

Wanner, Zukiswa. London, Cape Town, Joburg. Kwela Books, 2014. . Men of the South. Kwela Books, 2010. . The Madams: A Wildly Provocative Novel. Oshun, 2006.

West, Edward. "The Point Is Durban's 'Huge Confidence Booster.'” Business Registration Office, Durban, 4 March 2013, www.durban.bizro.co.za/thepoint-is-durbans-huge-confidence-booster/. Accessed 18 Dec. 2015.

Wicks, Jeff. “Twitter Erupts after KZN Estate Agent Calls Black People 'Monkeys.'” Mail\&Guardian, 4 Jan. 2016, www.mg.co.za/article/2016-01-04twitter-erupts-after-kzn-estate-agent-calls-black-people-monkeys. Accessed 20 Oct. 2017.

Wicomb, Zoë. Playing in the Light. The New Press, 2006.

"Shame and Identity: The Case of the Coloured in South Africa." Writing South Africa: Literature, Apartheid, and Democracy, 1970-1995, edited by Derek Attridge and Rosemary Jolly, Cambridge University Press, 1998, pp. 91-107.

Willemse, Hein. "Afrikaans Literature, 1948-1976." The Cambridge History of South African Literature, edited by David Attwell and Derek Attridge, Cambridge University Press, 2012, pp. 429-452.

Williams, Tennessee. The Glass Menagerie. 1944. New Directions Books, 2011.

van Woerden, Henk. The Assassin: A Story of Race and Rage in the Land of Apartheid. Translated by Dan Jacobson, Picador, 2000.

Worden, Nigel, et al. Cape Town: The Making of a City - An Illustrated Social History. David Philip Publishers, 1998.

van Wyk, Johan. Man Bitch. 2nd ed., Johan van Wyk, 2006. 
. "Man-bitch: Poetry, Prose, and Prostitution." Interview with Judith Lütge Coullie. Selves in Question: Interviews on Southern African Auto/Biography, edited by Judith Lütge Coullie et al., University of Hawai'i Press, 2006, pp. 379-407.

. Man Bitch. $1^{\text {st }}$ ed., Johan van Wyk, 2001.

. My Name Is Angel but I'm not from Heaven in Any Way. Johan van Wyk, 2000.

. Gesig van die Liefde: Ingrid Jonker. Johan van Wyk, 1999.

. "Catastrophe and Beauty: Ways of Dying, Zakes Mda's Novel of the Transition." Literator, vol. 18, no. 3, 1997, pp. 79-90.

. Oe in ' $n$ Kas. Human and Rousseau Publishers, 1996.

. Constructs of Identity and Difference in South African Literature. Centre for the Study of Southern African Literature and Languages (CSSALL), University of Durban-Westville, 1995.

. “Die Dood, die Minnaar en die Oedipale Struktuur in die Ingrid JonkerTeks." PhD Thesis, Rhodes University, 1987. . Bome Gaan Dood Om Jou. Human and Rousseau Publishers, 1981. . Heldedade Kom Nie Dikwels Voor Nie. Perskor Publishers, 1978.

. Deur die Oog van die Luiperd. Human and Rousseau Publishers, 1976.

van Wyk, Lisa. "City Meets Celluloid." MailEGuardian, 29 Nov. 2011, www.mg.co.za/article/2011-11-29-city-meets-celluloid. Accessed 11 Aug. 2015.

Zuma, Jacob. "President Zuma Addresses the Nation - Pretoria, 01 April." YouTube, 01 Apr. 2016, www.youtube.com/watch?v=EBucRobI4rM. Accessed 27 Apr. 2016.

Zweifel, Philippe. "Eine Lanze für die Drachen." Sonntagszeitung, 16 Aug. 2015, pp. 51-52. 


\section{TABLE OF FIGURES}

Figure 1 (p. 40):

Map of Grey Street area. Adapted from: www.roomsforafrica.com/ dest/south-africa/kwazulu-natal/durban.jsp?tab=3. Accessed 5 Sept. 2017.

Figure 2 (p. 50):

Afzal Building on 292 Grey Street. Moreillon, Olivier. Personal Photo, 2015.

Figure 3 (p. 51):

Haribol Superette on the Corner of Grey and Lorne Street. Moreillon, Olivier. Personal Photo, 2015.

Figure 4 (p. 68):

Map of District Six, now Zonnebloem. Adapted from: www.google.ch/maps/. Accessed 5 Sept. 2017.

Figure 5 (p. 71):

St. Mark's Anglican Church in Zonnebloem. Moreillon, Olivier. Personal Photo, 2015.

Figure 6 (p. 109):

Map of Durban's (Greater) Point Area. Adapted from: www.google.ch/ maps/. Accessed 5 Sept. 2017.

Figure 7 (p. 118):

Oxford House and Four Seasons Hotel in Gillespie Street. Moreillon, Olivier. Personal Photo, 2015.

Figure 8 (p. 120):

Costa Do Sol Bar in Dr Pixley Kaseme Street. Moreillon, Olivier. Personal Photo, 2015.

Figure 9 (p. 141):

Map of Sea Point and Green Point. Adapted from: www.google.ch/maps/. Accessed 5 Sept. 2017. 
Figure 10 (p. 165):

View of Table Mountain and Devil's Peak from V\&A Waterfront. Moreillon, Olivier. Personal Photo, 2015.

Figure 11 (p. 185):

Social Geography in Strange Nervous Laughter. Moreillon, Olivier, 2015.

Figure 12 (p. 198):

Beth and Pravesh's Dating Itinerary Displayed on Map of KwaZulu-Natal. Adapted from: www.google.ch/maps/. Accessed 5 Sept. 2017.

Figure 13 (p. 235):

Cover of the First South African Edition of Moxyland by Jacana Media. From: www.goodreads.com/book/show/3491640-moxyland. Accessed 5 Sept. 2017.

Figure 14 (p. 240):

"Mbeki Clarifies Circumstances - 'The Tragedy of History.'” Caricature by Zapiro in The Times, 14 January 2016. From: www.zapiro.com/160114tt. Accessed 5 Sept. 2017. 

This study analyses the representation of Durbanite and Capetonian urban spaces in the following selection of post-apartheid works: Mariam Akabor's Flat 9, Rozena Maart's Rosa's District Six, Johan van Wyk's Man Bitch, K. Sello Duiker's Thirteen Cents, Bridget McNulty's Strange Nervous Laughter, and Lauren Beukes' Moxyland. The focus lies on the interrelatedness of shifting post-apartheid subjectivities and urban space (and place) in these literary works. The analysis not only grants access to different 'new voices' of post-apartheid literature, it also sheds light on the perception of South African history, urban geography, and cultural topography - essentially, on real as well as imagined South African urban spaces - as the literary representations of city-spaces become archives of cultural transformation processes; a gateway to the understanding of the developments and changes of, and within, the two cities in question.

\section{Logos Verlag Berlin}

